\title{
Het werk van verpleegkundigen in algemene ziekenhuizen : een onderzoek naar werkaspecten en hun invloed op verpleegkundigen
}

Citation for published version (APA):

Boumans, N. P. G. (1990). Het werk van verpleegkundigen in algemene ziekenhuizen : een onderzoek naar werkaspecten en hun invloed op verpleegkundigen. [Doctoral Thesis, Maastricht University]. Rijksuniversiteit Limburg. https://doi.org/10.26481/dis.19900406nb

Document status and date:

Published: 01/01/1990

DOI:

10.26481/dis.19900406nb

Document Version:

Publisher's PDF, also known as Version of record

Please check the document version of this publication:

- A submitted manuscript is the version of the article upon submission and before peer-review. There can be important differences between the submitted version and the official published version of record.

People interested in the research are advised to contact the author for the final version of the publication, or visit the DOI to the publisher's website.

- The final author version and the galley proof are versions of the publication after peer review.

- The final published version features the final layout of the paper including the volume, issue and page numbers.

Link to publication

\footnotetext{
General rights rights.

- You may freely distribute the URL identifying the publication in the public portal. please follow below link for the End User Agreement:

www.umlib.nl/taverne-license

Take down policy

If you believe that this document breaches copyright please contact us at:

repository@maastrichtuniversity.nl

providing details and we will investigate your claim.
}

Copyright and moral rights for the publications made accessible in the public portal are retained by the authors and/or other copyright owners and it is a condition of accessing publications that users recognise and abide by the legal requirements associated with these

- Users may download and print one copy of any publication from the public portal for the purpose of private study or research.

- You may not further distribute the material or use it for any profit-making activity or commercial gain

If the publication is distributed under the terms of Article $25 \mathrm{fa}$ of the Dutch Copyright Act, indicated by the "Taverne" license above, 


\section{HET WERK VAN VERPLEEGKUNDIGEN IN ALGEMENE ZIEKENHUIZEN:}

Een onderzoek naar werkaspecten

en hun invloed op verpleegkundigen 


\title{
HET WERK VAN VERPLEEGKUNDIGEN IN ALGEMENE ZIEKENHUIZEN:
}

\author{
Een onderzoek naar werkaspecten \\ en hun invloed op verpleegkundigen
}

\author{
Proefschrift \\ ter verkrijging van de graad van doctor \\ aan de $\mathbb{R}$ ijksuniversiteit Limburg te Maastricht, \\ op gezag van de Rector Magnificus, Prof. Dr. F.I.M. Bonke, \\ volgens het besluit van het College van Dekanen, \\ in het openbaar te verdedigen \\ op vrijdag, 6 april 1990 om 14.00 uur \\ door \\ Nicolle Paulina Gerarda Boumans \\ geboren te Heerlen in 1963
}




\title{
HET WERK VAN VERPLEEGKUNDIGEN IN ALGEMENE ZIEKENHUIZEN:
}

\author{
Een onderzoek naar werkaspecten \\ en hun invloed op verpleegkundigen
}

\author{
Proefschrift \\ ter verkrijging van de graad van doctor \\ aan de Rijksuniversiteit Limburg te Maastricht, \\ op gezag van de Rector Magnificus, Prof. Dr. F.I.M. Bonke, \\ volgens het besluit van het College van Dekanen, \\ in het openbaar te werdedigen \\ op vrijdag, 6 april 1990 om 14.00 uur \\ door \\ Nicolle Paulina Gerarda Boumans \\ geboren te Heerlen in 1963
}




\section{Promotor:}

Prof. Dr. J.J.C.B. Bremer

Coupromotor:

Dr. J.A. Landeweerd

Beoordelingscommissie:

Prof. Dr. H. Phillipsen (voorzitter)

Prof. Dr. J.A. Algera (Technische Universiteit Eindhoven)

Prof. Dr. A.H.M. van den Bergh-Braam

Dr. A. Visser

Prof. Dr. J.A.M. Winnubst (Rijksuniversiteit Utrecht)

CIP-GEGEVENS KONINKLIIKE BIBLIOTHEEK, DEN HAAG

Boumans, Nicolle Paulina Geraurda

Het werk van verpleegkundigen in algemene ziekentwizen:

een onderzoek naar werkaspecten en hun invloed op

verpleegkundigen / Nicolle Paullina Gerarda Boumans.

Maastricht: Datawyse, - Ill.

Proefschrift Maastricht. - Met lit. opg. - Met samenvatting

in het Engels.

ISBN 90-5291-021-9

SISO 613.3 UDC [614.253.5:331.101] (043.3)

Trefw.: verpleegkundigen : ziskenhuizen.

\section{Lay-out:}

Isel van Noppen

Produktie:

Datawyse Maastricht

Druk:

Krips Repro Meppel

Aan het verschijnen van dit proefschrift is financieel bijgedragen door Mölnlycke Nederland BV (Amstelveen) en Medical Transfer (Amsterdam) 


\section{INHOUDSOPGAVE}

pagina

1. INLEIDING 9

1.1 Inleiding 9

1.2 Probleemstelling 10

1.3 Doelstelling $\quad 11$

$\begin{array}{ll}1.4 & \text { Opbouw van de dissertatie } \\ & 12\end{array}$

2. ONDERZOEK NAAR WERK EN REACTIES IN DE VERPLEGING: 13 EEN LITERATUUROVERZICHT

$\begin{array}{lll}2.1 & \text { Inleiding } & 13\end{array}$

2.2 Onderzoek naar werkaspecten 15

2.2.1 Inleiding 15

2.2.2 Bevindingen ten aanzien van de zeven categorieën werkaspecten 17

2.2.3 Vergelijkend onderzoek tussen intensieve en algemene 21 verpleegafdelingen

$2.3 \quad$ Onderzoek naar reacties bij verpleegkundigen 23

$2.4 \quad$ Onderzoek naar individuele/psychosociale kenmerken 25

$2.5 \quad$ Onderzoek naar de relaties tussen werkaspecten en reacties 27

2.6 Onderzoek naar de invloed van individuele/psychosociale kenmerken 31

$\begin{array}{lll}2.7 & \text { Conclusies } & 34\end{array}$

3. DE THEORETISCHE ACHTERGROND VAN HET ONDERZOEK

3.1 Inlleiding 37

3.2 Achtergrond en beschrijwing van het "Job Characteristics Model" 38

3.3 De geldigheid van het "Job Characteristics Model" 41

3.3.1 De toetsing van de in het "Job Characteristics Model" gepostuleerde 41 relaties

3.3.2 De invloed van moderatoren 45

3.3.3 De dimensionaliteit van het taakdomein $\quad 47$

3.3.4 Het objectief versus subjectief meten wan taakkenmerken 49

$3.4 \quad$ Nabeschouwing $\quad 51$

4. ONDERZOEKSMODEL EN -METHODEN 53

4.1 Inleiding 53

4.2 Het onderzoeksmodel $\quad 53$

4.3 Planning en uitwoering van het onderzoek 54

4.4 Beschrijving van de onderzoekspopulatie 56

4.5 Toelichting op de variabelen 59

$\begin{array}{lll}4.5 .1 & \text { Inleiding } & 59\end{array}$

$\begin{array}{lll}\text { 4.5.2 De werkaspecten } & 60\end{array}$

4.5.2.1 Taakkenmerken $\quad 60$

4.5.2.2 Leiderschapsstill 61

$\begin{array}{lll}\text { 4.5.2.3 Verpleegsysteem } & 62\end{array}$ 
4.5.3 De reactie-wariabelen 65

4.5.3.1 Eigen werkwaardering 66

4.5.3.2 Satusfactie $\quad 66$

4.5.3.3 Gezondheidsklachten $\quad 67$

4.5.3.4 Ziekteverzuim $\quad 68$

4.5.4. De individuele/psychosociale kenmerken 68

4.5.4.1 Sociale ondersteuning 68

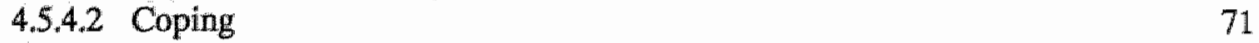

$\begin{array}{lll}4.5 .4 .3 & \text { Preferenties } & 73\end{array}$

$\begin{array}{lll}\text { 4.5.4.4 Biografische kenmerken } & 74\end{array}$

4.6 Reductie van het aantal variabelen 75

4.6.1 Beperking wan het aantal reactie-variabelen 75

4.6.2 Beperking wan het aantal individuele/psychosociale kenmerken 77

$\begin{array}{lll}4.7 & \text { De onderzoeksvraagstellingen } & 78\end{array}$

4.8 De analyses $\quad 81$

4.9 De aggregatieniveaus $\quad 83$

5. RESULTATEN "PRIMAIRE ONDERZOEKSVRAAGSTELLINGEN"

5.1 Inleiding 85

5.2 De samenhang tussen de werkaspecten en de reactie-variabelen 85

5.2 .1 Inleiding $\quad 85$

5.2.2 De onderlinge samenhang tussen de werkaspecten 85

$\begin{array}{lll}5.2 .3 & \text { Verzuimfrequentie } & 87\end{array}$

5.2.4 De samenhang tussen de werkaspecten en de reactie-variabelen 88

5.2.5 De samenhang tussen leiderschapsstijlen en reacties van verpleegkundigen 93

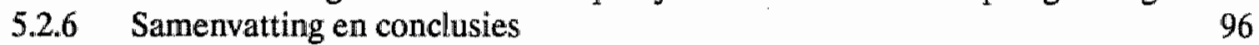

5.3 De rol van de individuele/psychosociale kenmerken 98

5.3.1 Inleiding 98

5.3.2 De modererende rol van de individuele/psychosociale kenmerken op $\quad 99$ de relatie tussen de werkaspecten en de reactie-variabelen

5.3.3 De individuele/psychosociale kenmerken als hoofdeffect op de $\quad 108$ reactie-variabelen

5.3.4 Het effect van de individuele/psychosociale kenmerken op de reactie- 109 variabelen wanneer gecontroleerd wordt voor de invloed van de werkaspecten

5.3.5 Samenvatting en conclusies

6. RESULTATEN "SECUNDAIRE ONDERZOEKSVRAAGSTELLINGEN" 115

6.1 Inleiding 115

6.2 De onderlinge samenhang tussen de reactie-variabelen 115

6.3 De onderlinge samenhang tussen de individuele/psychosociale $\quad 117$ kenmerken

6.4 Verschillen in scores van het verpleegkundig management en van $\quad 118$ de verpleegkundigen op de taakkenmerken

6.5 Samenvatting en conclusies 
pagina

$\begin{array}{ll}7 . & 125\end{array}$

$\begin{array}{lll}7.1 & \text { Inleiding } & 125\end{array}$

$\begin{array}{lll}7.2 & \text { De reikwijdte van het onderzoek } & 125\end{array}$

$\begin{array}{lll}7.3 & \text { Theoretische implicaties } & 126\end{array}$

7.4 Praktische implicaties $\quad 134$

7.4.1 Aanbevelingen ten aanzien van het organisationele ontwerp van de 134 verpleegafdeling

7.4.2 Aanbevelingen ten aanzien van opleidings- en bijscholingsprogramma's 136

7.4.3 Aanbevelingen ten aanzien van selectie- en loopbaambegeleiding 137

7.5 Aanbevelingen voor verder onderzoek 138

$\begin{array}{ll}\text { SAMENVATTING } & 139\end{array}$

$\begin{array}{ll}\text { SUMMARY } & 143\end{array}$

$\begin{array}{lr}\text { LITERATUUR } & 147\end{array}$

$\begin{array}{ll}\text { BLJLAGEN } & 161\end{array}$

$\begin{array}{lr}\text { DANKWOORD } & 177\end{array}$

$\begin{array}{lr}\text { CURRICULUM VITAE } & 178\end{array}$ 


\section{$1.1 \quad$ Inleiding}

Onderwerpen als arbeids(on)tevredenheid, burnout, stress- en gezondheidsbeleving van verpleegkundigen staan in toenemende mate in de belangstelling. Het welbevinden van verpleegkundigen in hun arbeidssituatie verdient niet alleen vanuit humane overwegingen, maar ook vanuit organisatorisch oogpunt de aandacht. Er heerst namelijk alom de mening, dat factoren zoals personeelsverloop en -verzuim en kwaliteit van de zorgverlening met gevoelsmatige reacties van verpleegkundigen op hun werk samenhangen. Tot voor kort kon een gebrek aan (onderzoeks-) belangstelling voor zaken zoals arbeidsvoldoening van verpleegkundigen gesignaleerd worden. Een mogelijke oorzaak hiervan zou kunnen zijn dat de verpleging door de eeuwen heen gezien is als een "roeping" en dat verpleegkundigen intrinsieke bevredigingsmomenten in overvloed hebben. De laatste jaren komt in deze visie verandering en ontstaat een opvallend toenemende interesse in het verband tussen genoemde variabelen en mogelijke determinanten en correlaten. Het achterhalen van oorzaken van negatieve reacties van verpleegkundigen op hun werk zoals arbeidsdissatisfactie, burnout, gezondheidsklachten, ziekteverzuim en verloop zou gezien moeten worden als een relevant beginpunt voor mogelijke interventies in de verpleegkundige praktijk. Deze oorzaken kunnen gelegen zijn in het werk zelf (bijvoorbeeld de taak, de structuur en organisatie van de afdeling). Bovendien kunnen individuele verschillen tussen verpleegkundigen en psychosociale factoren bepalend zijn voor de diverse wijzen waarop men tegen het werk aankijkt.

In deze dissertatie wordt verslag uitgebracht van een onderzoek waarin verbanden worden gelegd tussen verschillende aspecten van het werk (zoals de taakstructuur, het leiderschapsgedrag en het verpleegsysteem) en reacties van verpleegkundigen op dat werk (zoals arbeidstevredenheid, eigen werkwaardering, gezondheidsklachten en ziekteverzuim), waarbij rekening is gehouden met de invloed van individuele kenmerken van verpleegkundigen en psychosociale kenmerken die resulteren uit de interactie tussen verpleegkundigen en hun omgeving.

Voor een werkveld als de verpleging zijn de resultaten van een dergelijk onderzoek relevant, alleen al vanwege de ondersteunende functie die zij kunnen hebben bij het opstellen van beleidsmaatregelen en het doorvoeren van veranderingsprocessen in de praktijk.

Op het moment is er namelijk een aantal turbulente ontwikkelingen waar te nemen in de gezondheidszorg in het algemeen en specifiek in de verpleging die een mogelijke invloed hebben op de werksituatie en het takenpakket van verpleegkundigen.

De verwachting is dat de bezuinigingsmaatregelen, die tot forse personeelsinkrimpingen hebben geleid en mogelijk nog zullen leiden, de werkbelasting van de verpleegkundigen doen toenemen. Ook de vergrijzing van de bevolking zal waarschijnlijk resulteren in een verzwaring van de taken van verpleegkundigen. In de toekomst zullen meer oudere en meer intensieve zorg behoeftige patiënten opgenomen worden in intramurale gezondheidszorginstellingen.

De vraag die hierbij gesteld kan worden is of dit alles niet ten koste zal gaan van de kwaliteit van de verpleegkundige zorg en de aandacht die de individuele patiënt voor zijn persoonlijke behoeften nodig heeft. Vooral de laatste jaren is ruim aandacht besteed aan de mondigheid 
van de patient die meer wil weten over zijn behandeling en daarover mee wil kunnen beslissen. Bovendien staat vanuit een integrale mensvisie de benadering van de patiënt in $z^{\prime} n$ totaliteit steeds meer centraal. Velen in de verpleging zijn van mening dat de tot nu toe sterk medisch en/of verpleegtechnisch gerichte zorg uitgebreid moet worden met aandacht voor psychische en sociale aspecten. Deze nieuwe denkbeelden hebben op een aantal verpleegafdelingen reeds geleid tot veranderingen in het werk. Was men vroeger meer taakgericht bezig (functionele verpleging, vergelijkbaar met het Tayloriaanse lopende-band systeem; zie bijwoorbeeld Mercx, 1975a), nu probeert men te gaan werken in de richting van patiëntgerichte zorgverlening (taakverrijking, taakwerruiming). De behandeling van de patiënt als somatisch-psychisch-sociale eenheid moet in deze nieuwe vorm van verplegen meer naar voren komen. De traditionele organisatiestructuur van de verpleging, waarin taaksplitsing en taaktoewijzing centraal staan, werkt vaak dysfunctioneel ten aanzien van de patiënt en bovendien demotiverend voor de verpleegkundige (Van Bergen, 1972).

Onder invloed van de technische en medische vooruitgang neemt de complexiteit van de verpleging toe en wordt het takenpakket van verpleegkundigen voortdurend veranderd en uitgebreid. Vooral intensive care-verpleegkundigen verrichten steeds vaker technische handelingen die traditioneel en wettelijk tot het terrein van de arts behoren. Uit een recent onderzoek verricht onder ICU-verpleegkundigen in Nederland (Dassen e.a., 1987) bleek dat de meerderheid van de verpleegkundigen regelmatig zelfstandig medische handelingen verricht, dat wil zeggen zonder direct toezicht van een arts.

In Nederland is slechts op beperkte schaal geprobeerd bepalende factoren van reacties van verpleegkundigen op hun werk op te sporen. Noemenswaardig op dit gebied zijn wellicht de onderzoeken van Cassee (1965), Zwaga (1983) en Van den Bergh-Braam (1984) die vanuit respectievelijk het leiderschapsconcept en de roltheoretische benadering reacties zoals rolstress, arbeidssatisfactie, verloopgeneigdheid, daadwerkelijk verloop en ziekteverzuim hebben trachten te voorspellen. Het literatuuroverzicht van Smulders e.a. (1985) geeft een goede samenvatting van dit onderzoeksveld, maar is niet uitsluitend gericht op de verpleging en de Nederlandse situatie.

Dit tekort aan dergelijke sociaal-wetenschappelijke studies naar werk en reacties in de verpleging, dat in schril contrast staat met het vele onderzoek dat op dit terrein verricht is in de industriële setting (zie bijvoorbeeld Vroom, 1964; Dunnette, 1976; Gruneberg, 1979; McCormick en Ilgen, 1980), vormde de aanleiding tot het onderhavige onderzoek.

Empirische studies in de industrie laten zien hoezeer kenmerken van werk van invloed zijn op de reacties van werknemers. De meest recente benadering in het onderzoeksveld van deze taakkenmerkenbenadering is het "Job Characteristics Model"van Hackman en Oldham $(1975,1976)$, dat als theoretisch uitgangspunt heeft gediend van deze studie.

\subsection{Probleemstelling}

De probleemstelling van het onderhavige onderzoek wordt weergegeven in figuur $1.1 \mathrm{en}$ is als volgt geformuleerd: 
"Wat is de relatie tussen aspecten van het werk van verpleegkundigen en hun reacties op dat werk en wat is de invloed van individuele en psychosociale kenmerken op deze relatie (buffereffect) enlof op reacties van verpleegkandigen (hoofdeffect)?"
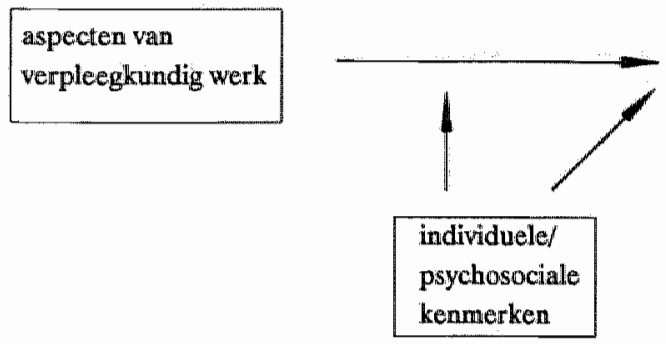

reactios van verpleegkundigen

Figuur 1.1. Het theoretisch kader wan de studie

Een invulling van de afzonderlijke concepten en het formuleren van specifieke vraagstellingen zal plaatsvinden aan de hand van een literatuuronderzoek, waarin een nadere bestudering verricht zal worden van:

- de onderzoeken in de verpleging betreffende het terrein van de geponeerde probleemstelling en

- het theoretisch kader van waaruit deze probleemstelling behandeld gaat worden.

\subsection{Doelstelling}

De doelstelling van het onderzoek is het nagaan van de bruikbaarheid van de taakkenmerkenbenadering voor een verpleegkundige onderzoekssituatie. De bruikbaarheid van een dergelijke benadering is concreet vertaalbaar in twee afzonderlijke subdoelstellingen waaruit afgeleid kan worden dat de resultaten van het onderzoek, naast de toe te kennen wetenschappelijke waarde, een bijdrage leveren aan de ontwikkeling en professionalisering van een beroepsgroep in beweging. Deze twee subdoelstellingen kunnen als volgt worden geformuleerd:

1. Het onderzoek beoogt de toepasbaarheid te achterhalen van de taakkenmerkenbenadering ten aanzien van de beschrijving en voorspelling van verschijnselen zoals arbeidstevredenheid, eigen werkwaardering, gezondheidsklachten en ziekteverzuim bij een verpleegkundige onderzoekspopulatie. Met andere woorden nagegaan wordt in hoeverre het mogelijk is determinanten van reacties van verpleegkundigen op hun werk(situatie) op te sporen vanuit de uitgangspunten van een theoretisch model zoals het "Job Characteristics Model" van Hackman en Oldham $(1975,1976)$.

2. Voorzover het mogelijk blijkt determinanten van reacties van verpleegkundigen met een dergelijk onderzoek te achterhalen, wordt tevens beantwoording beoogd van de vraag of met behulp van de verkregen resultaten toekomstig beleid onderbouwd kan worden bijvoorbeeld ten aanzien van het organisationele ontwerp van verpleegafdelingen, het ontwerp 
van doelgerichte opleidings- en bijscholingsprogramma's en selectie- en loopbaanbegeleiding.

Ter exploratie van de bruikbaarheid van de taakkenmerkenbenadering en specifiek het "Job Characteristics Model" is een aantal stappen noodzakelijk:

1. Modificatie en aanpassing van het taakkenmerkenmodel aan de verpleegkundige werksituatie.

2. Aanpassing, ontwikkeling en toetsing wan de psychometrische eigenschappen van meetinstrumenten die de onderscheiden variabelen in een verpleegkundige setting meetbaar moeten maken.

3. Bestudering van relaties tussen de verschillende onderzoeksvariabelen geponeerd in het onderzoeksmodel van de huidige studie en geconcretiseerd in de afzonderlijke deelvraagstellingen.

\subsection{Opbouw van de dissertatie}

Naast deze inleiding bestaat de dissertatie uit een zestal andere hoofdstukken. Hoofdstuk 2 geeft een nadere bestudering weer van de onderzoeken die tot nu toe in de verpleging verricht zijn naar werk en reacties van verpleegkundigen op dat werk.

Hoofdstuk 3 biedt het theoretisch kader van deze studie. Er zal nader ingegaan worden op de achtergrond en de huidige problematiek binnen dit onderzoeksveld.

Op grond van de voorgaande twee hoofdstukken zal in hoofdstuk 4 een beschrijving gegeven worden van de uitbreiding en aanpassing van het taakkenmerkenmodel in de verpleging en zullen het onderzoeksmodel en de specifieke onderzoeksvariabelen en -vraagstellingen gepresenteerd worden. Bovendien vindt in dit hoofdstuk een bespreking plaats van een aantal onderwerpen dat met de gebruikte methoden te maken heeft. Hoofdstuk 5 geeft een overzicht van de belangrijkste resultaten ten aanzien van de primaire onderzoeksvraagstellingen en in hoofdstuk 6 worden de resultaten behandeld met betrekking tot de secundaire onderzoeksvraagstellingen.

Het verslag wordt tenslotte afgesloten met een bespreking van de reikwijdte van de studie, theoretische en praktische implicaties en aanbevelingen voor verder onderzoek in de nabeschouwing van hoofdstuk 7 . 


\section{ONDERZOEK NAAR WERK EN REACTIES IN DE VERPLEGING: EEN LITERATUUROVERZICHT}

\section{$2.1 \quad$ Inleiding}

In dit hoofdstuk wordt een overzicht gegeven van de onderzoeken die in de verpleging werricht zijn naar het werk op de verpleegafdeling en de reacties die verpleegkundigen vertonen op dat werk. De bedoeling hiervan is te komen tot een bespreking van de resultaten en tekortkomingen van dit soort onderzoek. Deze analyse is mede van groot belang voor opzet en uitvoering van het onderhavige onderzoek.

Bij de bestudering van de studies die tot nu toe aangaande het werk in de verpleging verricht zijn kwam het concept "stress" steeds als belangrijk begrip naar voren. $\mathbb{R}$ eeds in de beginjaren "60 verschenen beschrijvingen van situaties waaruit blijkt dat de verpleging in het algemeen als stressvol gezien moet worden (Menzies, 1960; Holsclaw, 1965). Latere artikelen richten hun aandacht meer op de werkomgeving van de Intensieve verpleegafdelingen(ICU/CCU/.C-CCU 1 ). De complexe werksituatie die kenmerkend voor dit type afdeling is, stelt hoge eisen aan de verpleegkundige. Dit kan aanleiding geven tot een hoge mate van ervaren stress, arbeidsontevredenheid en hoge verloop-en verzuimcijfers. Er wordt onder andere gewezen op problemen met betrekking tot de geautomatiseerde werkomgeving, de hoge werkdruk, de grote veranitwoordelijkheden die verpleegkundigen moeten dragen en de psychisch belastende aspecten van de verzorging van ernstig zieke patjënten (Koumans, 1965; Vreeland en Ellis, 1969).

De trend om de intensive care afdelingen als onderwerp van studie te kiezen heeft ook in latere jaren doorgezet. Op dit moment is het merendeel van de studies over stress in de verpleging geconcentreerd geweest op de intensieve verpleegafdeling. Dit heeft onder andere bijgedragen tot de wijdverspreide veronderstelling dat intensieve verpleging stressvoller zou zijn dan de niet-intensieve, meer algemene verpleging.

Meer recent wordt gewezen op een tekort aan onderzoek op deze meer algemene verpleegafdelingen en aan studies die een vergelijking maken tussen de intensieve en algemene verpleging (Cross en Kelly, 1983; Cross en Fallon, 1985; Kelly en Cross, 1985).

Een moeilijkheid bij het opstellen van een overzicht van de onderzoeken naar werk en reacties in de verpleging is het meerduidig en daardoor verwarrend gebruik van het begrip "stress" "Het begrip "stress" werd zowel gehanteerd in studies die stressvolle situaties en gebeurtenissen in kaart brachten (stress als stimulus) als ook in studies die een beschrijving gaven van de mogelijke reacties van verpleegkundigen op de werksituatie (stress als reactie). Een duidelijke definitie en theoretische afbakening van het concept "stress" en daarmee samenhangende begrippen als stressor, stimulus, strain, coping en burnout ontbrak praktisch in alle onderzoeken. Het verwarrend gebruik van het begrip "stress" is begrijpelijk gezien de veelheid van disciplines die zich met onderzoeken op het gebied van stress hebben beziggehouden. Bovendien is de definitie van stress afhankelijk van het aandachtsveld dat men als uitgangspunt neemt (stimulus, respons, transactioneel). Voor een uitgebreide behandeling van deze problematiek wordt verwezen naar Van Dijkhuizen (1980), Van Bastelaer en Van Beers (1982), Reiche (1982) en Marcelissen (1987).

Voor de bevordering van de leesbaarheid van het literatuuroverzicht in dit hoofdstuk is het noodzakelijk dat enkele veel voorkomende begrippen omschreven worden. Giezien vanuit de 
verschillende benaderingswijzen van het concept "stress" begeeft men zich op een complex terrein indien men een definitie van stress probeert op te stellen. Auteurs zoals Van Bastelaer en Van Beers (1982), Kleber (1982) en Marcelissen (1987) geven dan ook aan, dat een omschrijving van het stressbegrip minder belangrijk is als wel een duidelijke afbakening van de vraagstelling, het stressproces en de verschillende variabelen die daarbinnen een rol spelen. In aansluiting op deze opvatting worden hier dan ook die begrippen omschreven die in het onderzoeksveld van stress als relevante onderdelen van dit proces beschouwd worden.

Zo wordt onder stressoren verstaan: kenmerken uit de objectieve werksituatie die door het individu als bedreigend worden ervaren, bijwoorbeeld werkbelasting (Reiche, 1982) (synoniem: bron van stress, stimuli). Wanneer een individu blootgesteld wordt aan de invloed van een stressor, zal hij proberen deze het hoofd te bieden en het bedreigende karakter van de stressor te reduceren met behulp van coping. Onder het begrip coping verstaan we in navolging van Schreurs (1987): de inspanningen van een individu indien de aan haar/hem gestelde eisen relevant zijn voor het welzijn (gezondheid, sociaal functioneren en zelfvertrouwen) en wanneer deze eisen een beroep doen op het aanpassingsvermogen. Indien de coping van het individu niet of niet voldoende effectief is kunnen strains optreden. Strains zijn volgens Reiche (1982) de negatieve geestelijke en lichamelijke gevolgen van stressoren, bijvoorbeeld ontevredenheid met het werk en te hoge bloeddruk. De indeling in strains van Van Bastelaer en Van Beers (1982) is specifieker. Zij maken namelijk onderscheid tussen werkgerelateerde strains (bijvoorbeeld werkontevredenheid), algemene affectieve strains (bijvoorbeeld geprikkeldheid), somatische strains (bijvoorbeeld algemene gezondheidsklachten), fysiologische strains (bijvoorbeeld bloeddrukverhoging) en gedragsmatige strains (bijvoorbeeld ziekteverzuim).

Wanneer een individu gedurende een langere periode in veeleisende situaties heeft verkeerd kan een toestand optreden die men aanduidt met de term "burnout". Dit begrip "burnout" wordt door Maslach en Jackson (1981) als volgt omschreven:"Burnout is a syndrome of emotional exhaustion and cynicism that occurs frequently among individuals who do 'people-work' of some kind". In deze omschrijving valt de nadruk dus op de psychische kant van burnout en wordt gesteld dat dit verschijnsel voorkomt bij diegenen die met mensen werken.

In dit hoofdstuk wordt bij het ordenen en beschrijven van de onderzoeken naar werk en reacties in de verpleging uitgegaan van het theoretisch kader dat reeds gepresenteerd werd in hoofdstuk $1 \mathrm{bij}$ de behandeling van de probleemstelling en nogmaals is weergegeven in figuur 2.1. Hierbij moet opgemerkt worden dat de samenhangen tussen individuele/psychosociale kenmerken en werkaspecten in de bespreking van de literatuur buiten beschouwing worden gelaten. In de onderhavige studie zijn we uitsluitend gericht op de directe dan wel indirecte invloed van de groep "derde" variabelen op reacties van verpleegkundigen.

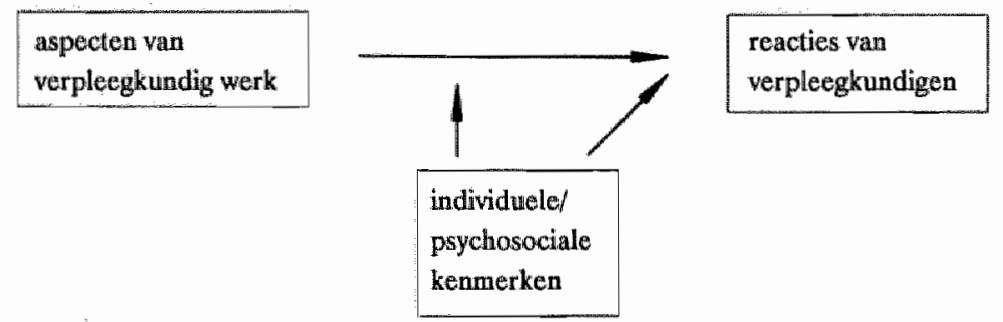

Figuur 2.1. Het theoretisch kader ter bespreking van relevant onderzoek 
Voor de in het theoretisch kader van figuur 2.1 vermelde begrippen zijn de volgende omschrijvingen opgesteld:

Werkaspecten: dit zijn kenmerken van de taak en/of van de organisatie van de verpleegafdeling die positieve dan wel negatieve gevolgen kunnen hebben voor reacties van verpleegkundigen (bijvoorbeeld autonomie, leiderschapsstijl).

Reacties: dit zijn positieve dan wel negatieve effecten van werkaspecten, die van psychische (bijvoorbeeld satisfactie, geprikkeldheid), psycho-somatische (bijvoorbeeld algemene malaise) en gedragsmatige aard (bijvoorbeeld ver* zuim) kunnen zijn.

Individuele: dit zijn kenmerken die toe te schrijven zijn aan individuen of aan de interacen psychosociale. kenmerken tie tussen individuen en de orngeving en die mede bepalend zijn voor effecten die werkaspecten op reacties kunnen hebben en/of op reacties een molijk eigenstandig effect hebben (bijvoorbeeld preferenties, sociale steun).

In aansluiting op deze inleidende paragraaf, waarin kort ingegaan is op de begrippen die in onderzoeken naar werk en reacties gehanteerd worden, is dit hoofdstuk opgebouwd uit de volgende paragrafen.

In paragraaf 2.2 wordt een beschrijving gegeven van de onderzoeken naar werkaspecten die in de verpleging verricht zijn ter nadere analyse en/of beschrijving van de werksituatie met name ter opsporing van problemen en knelpunten voor de verpleegkundigen.

Paragraaf 2.3 geeft een overzicht van de studies die zich hebben beziggehouden met de reacties van verpleegkundigen. Paragraaf 2.4 bevat een beschrijving van de resultaten van onderzoeken aangaande de inventarisatie van reacties-bepalende individuele en psychosociale kenmerken. Vervolgens wordt een samenvatting gegeven van die onderzoeken, die hebben geprobeerd relaties vast te leggen tussen de verschillende groepen variabelen. Zo wordt in paragraaf 2.5 een toelichting gegeven op relaties die gevonden zijn tussen werkaspecten en reacties en in paragraaf 2.6 op de invloed van de individuele en psychosociale kenmerken op reacties van verpleegkundigen of op de relatie tussen werkaspecten en reacties. In paragraaf 2.7 wordt het hoofdstuk afgesloten met een kort overzicht van de belangrijkste bevindingen, waarbij de tekortkomingen in verrichte studies besproken worden welke mede de aanleiding hebben gevormd van de opzet en uitvoering van het onderhavige onderzoek.

\subsection{Onderzoek naar werkaspecten}

\subsubsection{Inleiding}

In de verpleegkundige literatuur is veel aandacht besteed aan (de meting van) mogelijke situatieve oorzaken van reacties die verpleegkundigen op hun werk hebben (werkaspecten). Over het algemeen zijn daarbij drie methoden van dataverzameling gehanteerd:

1. subjectieve beschrijvingen; vooral de publicaties van v66r 1970 geven op basis van "eigen ervaring en observatie" subjectieve beschrijvingen van wat als stressvol op een verpleegafdeling gezien moet worden (Vreeland en Ellis, 1969). Ook enkele latere artikelen hebben overigens gebruik gemaakt van deze wijze van onderzoek (Bïlodeau, 1973, Cassem en Hackett, 1975). 
2. (semi)gestructureerde interviews door middel waarvan aan de respondent de vraag wordt gesteld aan te geven wat voor haar/hem bronnen van stress en/of (on)tevredenheid zijn (Cronin-Stubbs, 1977)

3. gestructureerde vragenlijsten veelal bestaande uit woorbeelden van (stressvolle) situaties en gebeurtenissen. De respondent moet op een schaal met in intensiteit oplopende schaalwaarden aangeven hoe stressvol de beschreven situaties voor haar/hem zijn (intensiteit) en/of hoe vaak dergelijke situaties/gebeurtenissen zich voordoen (frequentie) (Cronin-Stubbs en Rooks, 1985). Ook kan de respondent gevraagd worden het belang van bepaalde werkaspecten bij het bepalen van zijn arbeidssatisfactie en stressgevoelens aan te geven (Everly en Falcione, 1976).

De bedoeling van al deze onderzoeken was zowel stresserende als (on)tevredenstellende aspecten van de verpleegkundige werksituatie te identificeren, te beschrijven, te categoriseren of te rangordenen naar volgorde van belangrijkste bronnen van zowel stress als (dis)satisfactie. Zoals reeds eerder vermeld is onderzoek naar werkaspecten tot mu toe vooral gericht geweest op de intensieve verpleegafdelingen. Onderzoek naar aspecten van het werk op de algemene verpleegafdeling heeft slechts in beperkte mate plaatsgevonden. Evenmin is nawwelijks bekend in welke mate de werkaspecten die gevonden zijn op de ICU geldig zijn voor de algemene verpleging. Ook is het aantal onderzoeken dat een vergelijking heeft getroffen tussen de intensieve en algemene verpleging beperkt (zie 2.2.3).

In deze paragraaf zullen de bevindingen ten aanzien van enkele veel genoemde categorieën van werkaspecten besproken worden. Daarbij zal de indeling van Bailey e.a. $(1980 \mathrm{a}, 1980 \mathrm{~b})$ in zeven categorieën als leidraad dienen. Het onderzoek van Bailey e.a. is een van de meest uitgebreide studies naar oorzaken van stress en tevredenheid in de verpleging geweest. Met behulp van de vragenlijst "The Stress Audit" werden $1800 \mathrm{ICU}$-verpleegkundigen bevraagd over de volgende zeven categorieën werkaspecten:

1. management van de afdeling

2. interpersoonlijke relaties

3. patiëntenzorg

4. kennis en vaardigheden

5 . fysieke werkomgeving

6. gebeurtenissen in dagelijkse leven

7. organisatorische beloningen.

De indeling van Bailey e.a. is als leidraad genomen, omdat deze behoorlijk compleet lijkt en de zeven categorieën vrij uitgebreï zijn. Specifieke werkaspecten die in de verschillende studies besproken worden, kunnen zodoende makkelijk in de betreffende categorie ingedeeld worden. Indelingen van andere auteurs (bijvoorbeeld Leatt en Schneck, 1980) komen bovendien globaal overeen met die van Bailey e.a., maar zijn vaak minder goed uitgewerkt.

Na de bespreking van de afzonderlijke categorieën zullen de resultaten van de onderzoeken die een vergelijking hebben gemaakt tussen de intensive care afdeling en de algemene verpleegafdeling apart toegelicht worden (zie 2.2.3). Dit met het oog op de bestaande veronderstelling dat de intensieve verpleging stressvoller zou zijn dan de algemene verpleging.

Tenslotte moet opgemerkt worden dat bij de bespreking van de zeven categorieën werkaspecten ervan uitgegaan moet worden, dat de bevindingen betrekking hebben op de situatie van de intensieve verpleegafdeling (ICU, CCU, ICU-CCU), tenzij anders wordt aangegeven. Ook zal aangegeven worden wanneer de besproken literatuur gebaseerd is op subjectieve beschrijvingen; de namen van de auteurs zijn dan voorzien van een asterisk (*). 


\subsubsection{Bevindingen ten aamzien van de zeven catagorieën werkaspecten}

\section{1) MANAGEMENT WAN DE AFDELING}

\section{Personeelsbeziting en werklast}

Aan het management van de afdeling kumen diverse aspecten onderseheiden worden. In de onderzoeken van Baily e.a. (1980b), Grout e.a. (1981) en Burns e.a. (1983), waarin geprobeerd is een rangorde aan te brengen in bronnen van stress en tevredenheid voor ICU-verpleegkun w digen, kwam de categorie "het management wan de afdeling" als grootste veroorwaker van ervaren stress naar voren. Bovendien werd in alledrie de onderzoeken bünien deze categorie de factor "inadequate personeelsplanning en bezetting" als meest stressvol ervaren.

Ook in andere onderzoeken wordt een onvoldoende personeelsbezetting als belangrijkste oorzaak van stress (Oskins, 1979; Coghlan, 1984) en dissatisfactie (Cronin-Stubbs, 1977; Walsh en Bruni, 1983) aangewezen. De onderzoeken van Cronin-Stubbs (1977) en Walsh en Bruni (1983) zijn respectievelijk verricht bij een steekproef uit de verpleegkundige staf van twee ziekenhuizen en bij pas-afgestudeerde verpleegkundigen. Een variabele die nauw samenhangt met personeelsbezetting is werklast. Parkes (1985) maakt een onderscheid tussen werklast die ontstaat door de grote hoeveelheid werk en werklast die afgeleid kan worden van de complexiteit van het werk. De laatste vorm van werklast hangt samen met verschillende aspecten van de patiëntenzorg die besproken zullen worden onder deze betreffende categorie. Werklast in de zin van hoeveelheid werk is volgens Gentry en Parkes (1982) het resultaat van een inadequate personeelsplanning en bezetting. Werklast wordt in een aantal studies aangehaald als belangrijke stressor (Hay en Oken*, 1972; Gray-Toft en Anderson, 1981b; Dewe, 1987). Het onderzoek van Dewe (1987) is verricht bij een gestratificeerde steekproef uit de totale populatie verpleegkundigen in Nieuw Zeeland $(\mathrm{n}=2500)$. Bij de studie van Gray-Toft en Anderson (1981b) zijn 122 verpleegkundigen afkomstig van vijf algemene verpleegafdelingen uit een ziekenhuis betrokken geweest. In de overzichtsartikelen over stress op de ICU van Caldwell en Weiner (1981) en van Gentry en Parkes (1982) wordt geconcludeerd dat werklast als grootste bron van stress gezien moet worden. Gentry en Parkes zeggen hierover dat door een tekort aan personeel de kwetsbaarheid voor andere stressoren groter wordt. Bovendien wordt de hoeveelheid werk vaak bepaald door beslissingen van artsen, en vooral ook door het toestandsbeeld van de patiënt. Vooral op de ICU vinden vaak spoedopnames van patiënten plaats. De verpleegkundige zelf heeft hierop weinig invloed (Gray-Toft en Anderson, 1981b).

\section{Artsen}

Een andere bron van stress binnen de categorie "management" die veelvuldig vermeld wordt, is het moeten werken met een relatief onervaren groep artsen op de ICU (Oskins, 1979; Bailley e.a., 1980b; Grout e.a., 1981; Burns e.a., 1983). Bovendien zijn artsen niet altijd meteen beschikbaar op kritische momenten (Hay en Oken*, 1972; Bilodeau*, 1973; Caldwell en Weiner, 1981). Verpleegkundigen blijken waak aan te geven dat artsen verantwoordelijkheden op hen afschuiven met alle daaruit voor hen resulterende spanningen vandien (Jacobson, 1979).

\section{Leiding van de afdeling}

Een ander werkaspect in deze categorie is de leiding van de afdeling. Artikelen die de leiding van de verpleegafdeling tot onderwerp hebben, zijn vaak beschrijvend van aard. Zo beschreven Smith en Mitry* (1984) in hun artikel op welke manier het afdelingshoofd de verpleegkundi- 
gen kan beschermen ("buffer") tegen bepaalde problemen die zich voordoen in de organisatie en in relatie met anderen en welke positieve effecten hiermee bereikt kunnen worden. Mann ${ }^{*}$ (1978) geeft een opsomming van kwaliteiten die het hoofd van een ICU zou moeten bezitten. Hay en Oken ${ }^{*}$ (1972) attenderen op het feit dat verpleegkundigen vaak onvoldoende steun van hun afdelingshoofd ontvangen. Nichols e.a. (1981) die zowel verpleegkundigen van ICU's als van algemene verpleegafdelingen in hun onderzoek betrokken, $k w a m e n$ tot de bevinding dat gebrek aan ondersteuning en feedback van het afdelingshoofd voor beide groepen verpleegkundigen een bron van ontevredenheid vormt. Higthower (1986) onderzocht in zijn onderzoek het leiderschapsgedrag van hoofden wan afdelingen waar wel en geen "primary nursing" ${ }^{2}$ als verpleegsysteem werd gehanteerd. Afdelingshoofden van "primary nursing" afdelingen bleken meer relatie-gericht gedrag te vertonen dan afdelingshoofden van "non-primary nursing" afdelingen.

\section{Verpleegsysteem}

Een analyse van het gehanteerde verpleegsysteem op verpleegafdelingen heeft nauwelijks plaatsgevonden. Als uitzonderingen hierop zijn te vermelden Higthower (1986, zie onder "leiding van de afdeling") en Munson en Clinton (1979) (zie ook 2.5). Deze laatsten hebben getracht een meetinstrument te ontwerpen dat in staat is aspecten van "functional nursing" 2 ), "team nursing" ${ }^{2)}$ en "primary nursing" in kaart te brengen.

\section{2) INTERPERSOONLIIKE RELATIES}

\section{Interpersoonlijke problemen}

Onder deze categorie vallen de interpersoonlijke problemen die zich voordoen tussen verpleegkundigen en artsen, verpleegkundigen en de leiding en verpleegkundigen onderling. In de meeste onderzoeken werd aan dit aspect van de werksituatie aandacht besteed. De onderzoeken van Cronin-Stubbs (1977) bij pas-afgestudeerde verpleegkundigen en van Walsh en Bruni (1983) bij een steekproef uit de verpleegkundige staf van twee ziekenhuizen laten zien, dat problemen in interpersoonlijke relaties als belangrijke veroorzaker van dissatisfactie gezien moeten worden. In beide onderzoeken is aan de respondenten met behulp van semi-gestructureerde interviews gevraagd oorzaken van hun ontevredenheid aan te geven.

Sommige auteurs halen aan dat verpleegkundigen minder onderlinge conflicten blijken te hebben dan met respectievelijk artsen en verpleegkundige leiding (Huckabay en Jagla, 1979; Caldwell en Weiner, 1981; Burns e.a., 1983). Conflicten met artsen bebben vaak te maken met onzekerheid over de beroepsrol van verpleegkundigen. Voornamelijk de ICU-verpleegkundigen moeten regelmatig beslissingen nemen die traditioneel binnen het domein van cle arts vallen. Dientengevolge ontstaan zogenaamde dominantie- en territoriumconflicten (Caldwell en Weiner, 1981; Dassen e.a., 1987).

De onderzoeken van Bailey e.a. (1980b), Grout e.a. (1981) en Burns e.a. (1983) Iaten een opmerkelijk resultaat zien; het werkaspect "interpersoonlijke relaties" behoort tot éen van de grootste bronnen van zowel stress als satisfactie. Vooral de persoonlijke conflicten met artsen, leidinggevenden en collega-verpleegkundigen blijken tot stress te leiden (Grout e.a., 1981). Het werken in teamverband is voornamelijk een bron van tevredenheid.

\section{Groepscohesie}

Hay en Oken* (1972) attenderen op de rol van sterke groepscohesie op intensive care afdelingen. Het werk op een ICU vereist een sterke onderlinge afhankelijkheid en samenwerking tussen de 
verpleegkundigen. In noodgevallen worden verantwoordelijklheden woor elkaars patienten gedeeld, waarbij men volledig op de andere teamgenoten moet kunnen vertrouwen. Boven* dien worden de ICU-verpleegkundigen met hun speciale taken en kwaliteiten als een elitegroep binnen het ziekenhuis gezien, hetgeen de groepssamenhang bevordert. Hay en Oken* (1972) wijzen echter eveneens op de negatieve gevolgen van een dergelijke sterke groepscohesie; groepsnormen zijn dwingend, de druk vanuit de groep tot samenwerking kan tot gevolg hebben dat men gevoelens van vijandigheid en boosheid onderdrukt. Competitie voor promotie (Eisendrath en Dunkel*, 1979) en rivaliteit met betrekking tot het uitblinken in technische vaardigheden (Bilodeau*, 1973) kunnen aanleiding geven tot verdeeldheid binnen de groep.

\section{3) PATIENTENZORG}

\section{Omgang met ernstig zieke patiënten}

In de categorie van werkaspecten betreffende de "patiëntenzorg" leiden volgens de onderzoeken van Bailey e.a. (1980b), Grout e.a. (1981) en Burns e.a. (1983) sommige werkaspecten tot stress, andere tot tevredenheid. Zowel bij Grout e.a. (1981) als bij Burns e.a. (1983) werden binnen de categorie "patiëntenzorg" de spoedgevallen, hartstilstanden en fatale aflopen als grootste bronnen van stress gezien. Het meest tevredenstellend was de vooruitgang en het uiteindelijk herstel van de patiënt. Het verzorgen van ernstig zieke en stervende patiënten en de uiteindelijke dood van patiënten is een heel specifieke stressor waaraan diverse auteurs uitgebreid aandacht besteden (Caldwell en Weiner, 1981; Gentry en Parkes, 1982). Het merendeel van de auteurs wijst erop dat het omgaan met de dood van een patiënt een grote belasting voor ICU-verpleegkundigen vormt, welke nog wordt versterkt indien verpleegkundigen patiënten identificeren met eigen wrienden of familie (Hay en Oken*, 1972). Het tegemoetkomen aan de psychische behoeften van de patiënt en zijn familie wordt vaak als moeilijk en stressvol ervaren (Huckabay en Jagla, 1979). Men voelt zich vaak onvoldoende voorbereid om aan deze emotionele behoeften te voldoen (Gray-Toft en Anderson, 1981b). Hoe sterker de betrokkenheid bij de patiënt, des te moeilijker is het verwerken van diens dood (Eisendrath en Dunkel*, 1979). Alhoewel betrokkenheid van de kant van de verpleegkundige een troost voor de patiënt en diens familie kan betekenen, kan het voor de verpleegkundige gevoelens van verlies opleveren wanneer de patiënt uiteindelijk sterft (Hay en Oken*, 1972). Reacties van verpleegkundigen bij een sterftegeval zijn te vergelijken met de rouwverwerkingsfasen die Kübler-Ross (1978) onderscheid namelijk: gevoelens van ontkenning, falen, schuld, depressie en acceptatie (Eisendrath en Dunkel*, 1979).

\section{Verantwoordelijkheid}

Een andere bron van stress en dissatisfactie bij ICU-verpleegkundigen is de grote verantwoordelijkheid voor het leven van de patiënt (Caldwell en Weiner, 1981). In de onderzoeken van Cronin-Stubbs (1977) bij pas-afgestudeerde verpleegkundigen en Coghlan (1984) bij ICU-verpleegkundigen werd deze verantwoordelijkheid als belangrijke veroorzaker van stress en ontevredenheid gezien. Verpleegkundigen gaven aan dat ze veel te vroeg te veel verantwoordelijkheid toebedeeld kregen. Het onderzoek van Parkes (1985) bij eerstejaars leerling-verpleeg-kundigen wijst ook de verantwoordelijkheid en de daarmee samenhangende onzekerheid over eigen kennis en bekwaamheden als stressor aan. 


\section{Familie van de patient}

Een laatste bron wan stress in de categorie "patiëntenzorg" die iets minder belangstelling heeft gehad, maar in het onderzoek van Oskins (1979) duidelijk naar voren komt, is de familie van de patięrit. Hay en Oken (1972) wijzen op de rol van de omstandigheid dat op de ICU vaak geen vaste bezoektijden vastgesteld worden, zodat de constante, zij her kortdurende, aanwezigheid van familieleden van de patiënt makkelijk tot last van het werplegend personeel kan worden. Dunkel en Eisendrath (1983) stellen dat de aanwezigheid van familie van de patiënt op de ICU zowel positieve als negatieve effecten op de verpleegkundige staf kan hebben. Voordelen kunnen zijn dat er voor de verpleegkundigen gelegenheid is feedback en waardering te ontvangen, waartoe de patiënt zelf vaak niet meer in staat is. Bovendien krijgen zij via de familie de kans de patiënt beter te leren kennen. Een bron van stress wordt het vaak als de familie onrealistische eisen gaat stellen en verwijten aan de verpleegkundigen gaat maken. Familieleden reageren op de dood van de patiënt vaak met vijandigheid en beschuldigen de verpleegkundige staf van de afdeling van onvoldoende zorg (Caldwell en Weiner, 1981).

\section{4) KENNIS EN VAARDIOHEDEN}

De hoeveelheid en verscheidenheid aan complexe technische apparatuur op de intensieve verpleegafdeling stelt enorme eisen aan de kennis en vaardigheden van de verpleegkundige (Hay en Oken*, 1972). De onbekendheid met de apparaten wordt door Driessen (1980) als een van de stressoren aangemerkt.

Of elementen binnen de categorie "kennis en vaardigheden" als stresserend ervaren worden, hangt nauw samen met de (on)zekerheid en (on)ervarenheid die de verpleegkundige heeft. Zodra de verpleegkundige eenmaal vertrouwen heeft in eigen competentie neemt de mate van stress die met deze factor samenhangt af en gaat hij de uitdaging die het werk biedt waarderen (Huckabay en Jagla, 1979). Zo blijkt in het onderzoek van Parkes (1985) de categorie "kennis en vaardigheden" een probleem voor de onderzochte eerstejaars leerling-verpleegkundigen op te leveren. Andere onderzoeken daarentegen laten zien dat werkaspecten die bimnen deze categorie geplaatst kunnen worden, gezien worden als bronnen van tevredenheid. Zo blijkt bijvoorbeeld uit het onderzoek van Grout e.a. (1981) dat door de (voornamelijk gediplomeerde) ICU-verpleegkundigen zaken zoals de gelegenheid hebben nieuwe ervaringen op te doen, intellectuele uitdaging en afwisseling in het werk als positief ervaren worden. Ook Burns e.a. (1983) laten zien dat het hebben van snel beschikbare resultaten, een optimale taakuitvoering en het kunnen toepassen van bekwaamheden op de ICU bronnen van tevredenheid zijn. De bevindingen van White en Maguire (1973) betreffende een gestratificeerde steekproef van leidinggevenden, afkomstig uit zes ziekenhuizen, stemmen hiermee overeen; mogelijkheden tot groei en erkenning zijn factoren die bijdragen tot de satisfactie van de verpleegkundigen.

\section{5) FYSIEKE WERKOMGEVNGG}

Diverse auteurs beschrijven uitsluitend op basis van persoonlijke observaties de stressvolle fysieke werkomgeving van de intensive care afdelingen (Hay en Oken* ${ }^{*}, 1972$; Bilodeau*, 1973; Eisendrath en Dunkel ${ }^{*}, 1979$ ).

Uit het onderzoek van Huckabay en Jagla (1979), waarin aan 46 ICU-verpleegkundigen gevraagd werd op een vijf-puntsschaal voor vier categorieën stressoren de mate van ervaren stress aan te geven, bleek dat de aspecten in de categorie "omgeving" slechts in geringe mate als stressvol beoordeeld werden. Een verklaring die de onderzoekers hiervoor gaven is dat de verpleegkun- 
dige weinig verandering in deze omgevingsfactoren kan aanbrengen. Bovendien treedt na verloop van tijd gewenning op. In het onderzoek van Oskins (1979) werd door de betrokken ICU-verpleegkundigen de overvolle, drukke en lawaaierige omgeving van de afdeling als eên van de zes meest stressvolle situaties aangegeven.

\section{6) PERSOONLUKE LEVENSGEBEURTENISSEN (VAN VERPLEEGKUNDIGEN) EN \\ 7) ORGANISATORISCHE BELONINGEN}

De laatste twee categorieën zijn in dit stuk samengenomen omdat over beide weinig bekend is. Dit komt omdat aspecten met betrekking tot deze categorieën in de vragenlijsten en interviews, die in de verschillende onderzoeken gebruikt werden, zelden opgenomen zijn. Uitzonderingen zijn de onderzoeken van Bailey e.a. (1980b), van Grout e.a. (1981) en van Burns e.a. (1983). Alledrie laten ze zien dat persoonlijke en familliaire levensproblemen (categorie: persoonlijke levensgebeurtenissen) en carrièremogelijkheden, salaris en andere tegemoetkomingen (categorie: organisatorische beloningen) niet of nauwelijks bijdragen aan. zowel gevoelens van stress als van tevredenheid. Jacobsen (1983) vond dat het conflict tussen gezinsverantwoordelijkheden en eisen die het werk stelt tot de minst stresswolle van de 52 geëvalueerde items behoorde.

Aan de andere kant blijkt uit het onderzoek van Oskins (1979) dat $76 \%$ van de verpleegkundigen het als stresswol ervaart om te werken op een drukke afdeling terwijl ze in een persoonlijke crisis verkeren.

Bij de categorie "persoonlijke levensgebeurtenissen" kan men zich overigens afvragen of deze wel gezien moet worden als stressor of eerder tot de individuele kenmerken gerekend behoort te worden.

\subsubsection{Vergelijkend onderzoek tussen intensieve en algemene verpleegafdelingen}

De meeste onderzoeken die tot nu toe onder de verschillende categorieën zijn aangehaald, beschrijven stressvolle en/of (on)tevredenstellende situaties en gebeurtenissen op de intensive care afdeling. Het zou verkeerd zijn hieruit te concluderen dat de intensieve afdeling daarom ook stressvoller zou zijn dan de meer algemene verpleegafdeling. Alleen onderzoeken die beide typen afdelingen vergelijken kunnen hier meer duidelijkheid in verschaffen.

Het aantal vergelijkende onderzoeken is niet uitgebreid. Een opsomming van de resultaten van dergelijke onderzoeken zal beter inzicht moeten geven in de veronderstelling dat de werksituatie van de intensieve verpleegafdelingen meer stressoren herbergt dan de werksituatie van de algemene afdelingen.

Kelly en Cross (1985) lieten 41 ICU-verpleegkundigen en 61 niet-ICU-verpleegkundigen (van interne en chirurgische afdelingen) afkomstig uit twee ziekenhuizen scoren op de volgende vijf hoofdcategorieën van werkaspecten: interpersoonlijke relaties, omgeving, patiëntenzorg, kennis en vaardigheden en management van de afdeling. Slechts op het werkaspect "werkruimte", behorende tot de categorie "omgeving", bleek verschillend gescoord te worden door de twee groepen verpleegkundigen. De werkruimte werd namelijk door de groep niet-ICUverpleegkundigen het meest frequent aangewezen als bron van stress.

Numerof en Abrams (1984) onderzochten met behulp van de "Nursing Stress Inventory" verschillen in stressoren tussen negen typen verpleegafdelingen, waaronder de ICU. Voor elk van de zes stressor-categorieën, bestaande uit meerdere items, werd een totale stress-score 
berekend (totaal score $=$ produkt van frequentie en intensiteit). Op de stress-scores van twee categorieën werden verschillen tussen de negen verpleegafdelingen gevonden. De verpleegkundigen wan de intensieve verpleegafdeling vertoonden niet de hoogste stress-scores, maar kwamen op de vierde plaats na de verpleegkundigen van een psychiatrische, een chirurgische en interne afdeling.

In het onderzoek van Cross en Fallon (1985) bij 118 verpleegkundigen werd een vergelijking getroffen tussen een ICU, een chirurgische afdeling, een afdeling obstetrie en een interne afdeling. Het meetinstrument van Bailey e.a. $(1980 \mathrm{a}, 1980 \mathrm{~b})$ werd toegepast om de stressoren in kaart te brengen. Door alle vier de afdelingen werden de stressoren: "inadequate personeelsplanning" en "onderbrekingen en papierwerk" (afkomstig uit de categorie "management") het meest frequent aangewezen als bronnen van stress. Vergelijking tussen de scores van de vier typen afdelingen toonde significante verschillen in vier categorieën stressoren, namelijk "management", "interpersoonlijke relaties", "patiëntenzorg" en "omgeving". In totaal werden op 10 van de 45 stressoren significante verschillen aangetroffen en acht van deze tien stressoren deden zich op de ICU het meest frequent voor. Over het algemeen vertoonde de afdeling ICU op de significant bevonden stressoren uit de eerste drie genoemde categorieën de meest negatieve scores.

In het onderzoek van Cronin-Stubbs en Rooks (1985) waren in totaall 296 verpleegkundigen betrokken, afkomstig uit drie ziekenhuizen en van vier soorten afdelingen, namelijk een ICU, een psychiatrische afdeling, een interne afdeling en een operatiekamer. Als meetinstrument werd de "Nursing Stress Scale" van Gray-Toft en Anderson (1981a) gebruikt. Deze schaal geeft inzicht in de frequentie en intensiteit van stressoren op het werk. Voor zowel de frequentie als de intensiteit zijn totaalscores berekend. Een vergelijking tussen de vier typen afdelingen liet zien dat de verpleegkundigen van de ICU en de interne afdelingen significant hoger scoorden dan de verpleegkundigen van de operatiekamer en de psychiatrische afdeling wat betreft zowel frequentie als intensiteit van de stressoren. Er werden geen verschillen gevonden tussen de ICU en de interne afdeling.

Leatt en Schneck (1980) onderzochten bronnen van stress bij leidinggevende verpleegkundigen afkomstig van negen verschillende typen afdelingen, waaronder intensieve verpleegafdelingen. De verpleegkundigen werd gevraagd voor 21 items aan te geven hoe stressvol de beschreven situaties ervaren worden en hoe vaak de situaties zich voordoen. De diverse afdelingen vertoonden een grote overeenkomst in soorten stressbronnen, maar bleken te verschillen in de mate waarin deze per afdeling voorkwamen. Er kon echter niet geconcludeerd worden dat het steeds dezelfde afdeling was waarop zich de stress-situaties het meest frequent voordeden.

Op basis van het taakkenmerkenmodel van Hackman en Oldham $(1975,1976)$ (zie hoofdstuk 3), onderzochten Joiner e.a. (1982) welke perceptie verpleegkundigen hebben van bepaalde taakkenmerken. Een totaalscore van deze taakkenmerken zegt iets over het motiverend vermogen van het werk, waarvan verondersteld wordt dat het een positieve invloed heeft op reacties van mensen op hun werk. Joiner e.a. vergeleken daarbij zes soorten werksituaties in de verpleging, namelijk die van de interne/chirurgische afdeling, van de psychiatrie, de obstetrie, de pediatrie, de CCU (hartbewaking) en andere afdelingen. De vergelijking liet zien dat van het werk op de CCU de hoogste motiverende invloed uitging en van het werk op de afdeling psychiatrie de laagste. 
Een aanzienlijk aantal onderzoeken heeft zich bezig gehouden met het opsporen en categoriseren van zowel stresserende als (on)tevredenstellende aspecten in de werksituatie. Baseren vroegere artikelen zich vooral op subjectieve beschrijvingen, recente onderzoeken maken bij voorkeur gebruik van meer gestructureerde onderzoeksmethoden. De meeste onderzoeken hebben zich echter gericht op de werksituatie van de intensieve verpleegafdeling. Als bronnen van stress en ontevredenheid wordt herhaaldelijk gewezen op: een inadequate personeelsplanning en -bezetting en de daarmee samenhangende werklast, het werken met onervaren artsen die nauwelijks beschikbaar zijn op kritische momenten, de leiding van de afdeling (management van de afdeling); persoonlijke conflicten met verpleegkundigen, artsen en leidinggevenden (interpersoonlijke relaties); spoedgevallen, hartstilstanden en fatale aflopen, verantwoordelijkheid voor het leven van patiënten, het appèl van de psychische behoeften van de patiënt en zijn familie (patiëntenzorg); onbekendheid met de apparatuur (kennis en vaardigheden); de overvolle, drukke, lawaaierige omgeving (fysieke werkomgeving).

Als bronnen van tevredenheid in het werk worden aangegeven: het werken in teamverband, de sterke groepscohesie (interpersoonlijke relaties); de vooruitgang en uiteindelijk herstel van de patiënt, de reacties van de familie van de patiënt (patiëntenzorg); gelegenheid hebben bekwaamheden toe te passen en nieuwe ervaringen op te doen, de intellectuele uitdaging en afwisseling (kennis en vaardigheden).

Tenslotte kan vermeld worden dat op grond van bestaande onderzoeken op dit moment niet geconcludeerd mag worden dat zich in het werk van de intensieve verpleegafdeling meer stresssituaties voordoen dan in het werk van de meer algemene verpleegafdeling. Vergelijkende onderzoeken komen namelijk tot tegenstrijdige resultaten. Mogelijke verklaringen hiervoor zouden gezocht kunnen worden in:

1) verschillen in meetinstrumenten;

- de stressor-categorieën en de afzonderlijk te meten items binnen die categorieën komen niet altijd overeen

- de uiteindelijk toegepaste scoreberekening is verschillend wat betreft frequentie en/of intensiteit

2) verschillen in onderzoekspopulaties;

- de verpleegafdelingen die als vergelijkingsgroep(en) in de onderzoeken zijn opgenomen zijn van verschillende typen

- er is niet of nauwelijks rekening gehouden met de invloed van achtergrondsvariabelen zoals leeftijd, geslacht, diensttijd op de gevonden verschillen tussen de afdelingen.

- het onderzoek van Leatt en Schneck (1980) is in tegenstelling tot de andere studies verricht bij leidinggevenden.

\subsection{Onderzoek naar reacties bij verpleegkundigen}

Naast het opsporen van mogelijke knelpunten in de verpleegkundige praktijk is men tevens nagegaan welke invloed aspecten van het werk hebben op verpleegkundigen. Echter in tegenstelling tot het vele onderzoek dat getracht heeft in de werksituatie stresserende/tevredenstê]lende werkaspecten op te sporen, hebben slechts weinig studies mogelijke reacties van verpleegkundigen centraal gesteld (Gentry en Parkes, 1982). De resultaten van dit beperkt aantal 
onderzokken geven aan dat verpleegkundigen over het algemeen tevreden zijn met hun werk (Nichols e.a., 1981; Gevtry en Parkes, 1982; Wallis, 1987). Echter met specifieke aspecten van het werk, zoals bijwoorbeeld feedback (Nichols e.a. 1981) en de mogelijkheid nieuwe dingen te leren (Ott e.a., 1983), blijken verpleegkundigen minder tevreden te zijn. Larson e.a. (1984) vonden dat de satisfactie groter is naarmate het werk belangrijker wordt gevonden en meer aan verwachtingen tegemoet komt.

Ook wordt er een nelatie gevonden tussen mogelijke reactie-variabelen onderling. Zo blijkt uit het onderzoek van Albrecht (1982) dat bumout negatief gecorreleerd is met verscheidene dimensies van tevredenheid, zoals het salaris, de leiding, de collega's en het werk zelf. Dolan (1987) komt tot eenzelfde bevinding. Bryson ea. (1985) laten zien dat arbeidstevredenheid negatief samenhangt met gespannenheid. Weisman e.a. (1981) vonden dat arbeidstevredenheid en verloopgeneigdhe negatief gecorreleerd zijn.

De meeste onderzoeken waarin reacties van verpleegkundigen bestudeerd zijn, kozen als uitgangspunt de vergelijking van bepaalde typen verpleegafdelingen. Vooral intensieve en algemene verpleegafdelingen zijn met elkaar vergeleken op diverse reactie-variabelen, wellicht met enkele uitzonderingen zoals het onderzoek van Conrad e.a. (1985), waarin een vergelijking plaatswond tussen bedrijfsverpleegkundigen en verpleegkundigen van algemene ziekenhuizen, en de onderzoeken van Sanger c.a. (1985) en Boumans en Landeweerd (1987b) (zie ook Landeweerd en Boumans, 1988b), die psychiatrische afdelingen met elkaar vergelijken.

Gentry e.a. (1972) bijvoorbeeld vonden dat ICU-verpleegkundigen meer depressies en geirriteerdheid ondervinden en verbale agressie uiten dan niet-1CU-verpleegkundigen, afkomstig van een medisch centrum, een ccu en een kritische zorg afdeling. In dit onderzoek van Gentry e.a. (1972) is de afdeling ICU echter niet vergeleken met meer algemene verpleegafdelingen, aangezien de afdelingen CCU en kritische zorg ook vormen van intensieve verpleging zijn. De resultaten van Maloney en Col (1982) daarentegen laten zien dat verpleegkundigen van nietICU's een significant grotere mate van angst ervaren, meer somatische klachten en persoonlij$\mathrm{ke} /$ familiaire problemen hebben en een grotere arbeidsontevredenheid vertonen dan verpleegkundigen die op een ICU werkzaam zijn. Maloney en Col geven in hun artikel niet aan welke afdelingen in de studie tot de groep niet-ICU's behoren. Johnson (1979) liet zien dat de mate van ervaren angst bij ICU-verpleegkundigen lager is dan bij verpleegkundigen van algemene interne en chinurgische afdelingen, echter hoger dan bij verpleegkundigen in de psychiatrie.

Cronin-Stubbs en Rooks (1985) kwamen tot de bevinding dat verpleegkundigen op niet-ICU's (een interne afdeling, een psychiatrische afdeling en een operatiekamer) meer burnout ondervinden dan verpleegkundigen op ICU's. Het concept "burnout" werd gemeten met de "Staff Burnout Scale for Health Professionals (SBS-HP) met subschalen voor respectievelijk een cognitief, een affectief, een gedragsmatig en psychofysiologisch aspect. Het is een van de weinige studies waarin zowel de werksituatie als mogelijke reacties van verpleegkundigen bestudeerd zijn en wel met als conclusie: hoewel ICU-verpleegkundigen hoger scoren op frequentie en intensiteit van stressoren (zie 2.2) dan de verpleegkundigen van twee van de drie in het onderzoek betrokken niet-ICU's, dragt het werk op een ICU niet bij tot een grotere mate van burnout. Cronin-Stubbs en Rooks veronderstellen dat andere factoren, zoals copinggedrag en persoonlijkheidskenmerken in deze een rol zullen spelen.

Keane e.a. (1985) vergeleken verpleegkundigen van een interne en chirurgische intensive care afdeling met verpleegkundigen van twee interne afdelingen en twee chirurgische afdelingen op de variabele "burnout". Met gebruik van dezelfde SBS-HP-vragenlijst als Cronin-Stubbs en Rooks (1985) vonden ze geen verschillen in burnout tussen de afdelingen. 
Landeweerd en Boumans (1988a) wergeleken een $\mathrm{CCU}$, een algemene chirurgische afdeling en drie psychiatrische afdelingen (een opname, een short-stay en een long-stay afdeling) op een aantal reactie-wariabelen. De verpleegkundigen van de CCU bleken het meest tevreden met bun werk te zijn. Daarentegen vertoonden de verpleegkundigen van de afdeling chirurgie de minste mate van geîrriteerdheid en ervaren belasting. In het algemeen werd het meest negatief gescoord (minst tevreden en meeste gezondheidsklachten) door de short-stay afdeling in het psychiatrisch ziekenhuis.

Het onderzoek van Dear e.a. (1982) toonde aan dat ICU-verpleegkundigen een grotere mate van tevredenheid met het werk in het algemeen ervaren dan niet-ICU verpleegkundigen. Wat betreft tevredenheid met salaris, promotie, leiding, collega's en verloop werden geen verschillen tussen beide groepen gevonden. In deze studie werd de groep niet-ICU-verpleegkundigen overigens niet nader gespecificeerd. Ook Nichols e.a. (1981) vonden geen verschil in de frequentie waarmee positieve gevoelens (gelukkig, vol vertrouwen) en negatieve gevoelens (gespannen, boos) werden gerapporteerd door verpleegkundigen van intensieve en algemene (interne en chirurgische) verpleegafdelingen.

\section{SAMENVATTING}

Onderzoeken naar reacties van verpleegkundigen zijn aanzienlijk geringer in aantal dan de onderzoeken naar werkaspecten. Wat betreft relaties tussen reactie-variabelen onderling bleek burnout negatief te correleren met verschillende tevredenheidsdimensies en arbeidstevredenheid negatief met gespannenheid en verloopgeneigdheid.

De meeste onderzoeken naar reacties van verpleegkundigen betreffen een vergelijking tussen verpleegkundigen van verschillende typen verpleegafdelingen en met name van intensieve en niet-intensieve en wel op arbeidstevredenheid, psychische en psycho-somatische klachten, burnout en verloop. De studies die deze vergelijking getroffen hebben komen echter tot tegenstrijdige bevindingen. Sommige vinden dat verpleegkundigen van intensieve afdelingen meer negatieve reacties vertonen (Gentry e.a., 1972). Andere rapporteren dat het juist de verpleegkundigen van de niet-intensieve afdelingen zijn die het meest negatief op hun werk reageren (Dear e.a., 1982; Cronin-Stubbs en Rooks, 1985; Landeweerd en Boumans, 1988a). Ook zijn er onderzoeken die geen verschil gevonden hebben tussen beide groepen verpleegkundigen (Nichols e.a., 1981; Keane, 1985). Mogelijke verklaringen voor deze inconsistente bevindingen moeten waarschijnlijk weer gezocht worden in verschillen in gemeten variabelen, onderzoeksinstrumenten en -populaties (zie 2.2).

\subsection{Onderzoek naar individuele/psychosociale kenmerken}

Onderzoeken die in deze paragraaf besproken worden hebben betrekking op de inventarisatie van copingstrategieën bij verpleegkundigen zonder het geobserveerde copinggedrag te relateren aan andere variabelen en mogelijke effecten van bepaalde copingstrategieën te analyseren. Tot op heden is er niet veel aandacht besteed aan copinggedrag van verpleegkundigen, waarvan wordt aangenomen dat ze, in het bijzonder de intensive care-verpleegkundigen, onder een grote druk en spanning moeten werken en werk uitvoeren waarbij de kans op fatale afloop groot is (Gentry en Parkes, 1982).

Het meest uitgebreide onderzoek is van Oskins (1979). Hij onderscheidde 12 voorbeelden van mogelijke stressvolle situaties voor ICU-verpleegkundigen en ontwikkelde een lijst met 20 
copingstrategieen. In zijn onderzoek moesten ICU-verpleegkundigen voor elk van deze situaties een copingstrategie aangeven die ze zouden gebruiken. De bedoeling van Oskins onderzoek was te komen tot een inventarisatie en ordening van de meest gebruikte copingstrategieën, zonder een directe relatie te leggen tussen bepaalde stresssituaties en de daarin gehanteerde copingstrategieën. In meer dan 50 procent van de gevallen werden de volgende vier strategieen gehanteerd: "het probleem met anderen bespreken", "actie ondernemen", "een vergelijkbare situatie uit het verleden als referentiekader voor de huidige toestand gebruiken" en "angstig worden" (deze strategie zou veel meer als mogelijke reactie op een stressor gezien kunnen worden). Oskins concludeerde in zijn onderzoek dat verpleegkundigen in eerste instantie de directe actie mechanismen gebruiken. Pas in tweede instantie, nadat volgens Oskins de perceptie met betrekking tot de stressor verhelderd is, gebruikt de verpleegkundige "palliatieve strategieën" (vermindering van de ondervonden spanning door bijvoorbeeld afleiding te zoeken), die een tijdelijke oplossing moeten bieden.

De identificatie van copingstrategieën door Oskins en zijn onderscheid tussen "directe actie mechanismen" en "palliatieve strategieën" stemt overeen met de bevindingen in andere onderzoeken bij ICU-verpleegkundigen (Burns e.a.,1983; Coghlan, 1984; Kelly en Cross, 1985; Dewe, 1987). Kelly en Cross (1985) kwamen op grond van hun gegevens tot de conclusie dat verpleegkundigen over het algemeen meer adaptieve (praten, actie ondernemen) dan maladaptieve strategieèn (overmatig eten, depressief worden) hanteren, waarbij vermeld moet worden dat algemene verpleegkundigen meer gebruik maken van de mechanismen "huilen", "slecht slapen" en "overmatig eten" dan de ICU-verpleegkundigen. Overigens is de a priori indeling van Kelly en Cross (1985) in adaptieve en maladlaptieve strategieën gebaseerd op face value en niet op empirische gegevens die aantonen dat sommige strategieën inderdaad tot een betere aanpassing en verwerking leiden dan andere strategieën.

Een andere vraag die in verpleegkundig onderzoek de aandacht kreeg is door welke factoren de keuze van bepaalde copingmechanismen bepaald wordt. Volgens Kobasa e.a. (1979) beinvloeden persoonlijkheidskenmerken het copingproces. Zij identificeerden een set persoonlijkheidskenmerken die volgens hen tot "hardiness" leiden. Hardiness is volgens Kobasa e.a. de mate waarin personen stressbestendig zijn, hetgeen gekenmerkt wordt door een specifiek set van attitudes aangaande het leven, te weten:

- "uitdaging"; open staan voor veranderingen (versus "vertrouwdheid")

- "betrokkenheid"; zich betrokken voelen bij hetgeen men onderneemt (versus "vervreemding")

- "interne beheersing"; gevoel hebben dat men controle kan uitoefenen op gebeurtenissen (versus "externe beheersing").

Een gebrek aan deze attitudes leidt volgens Kobasa e.a tot burnout.

Maloney en Bartz (1983) zijn in hun onderzoek naar stresstolerantie uitgegaan van de bevindingen van Kobasa e.a. (1979). In een eerder onderzoek kwamen Maloney en Col (1982, zie 2.3) tot de conclusie dat niet-ICU-verpleegkundigen een grotere mate van angst ervaren, meer somatische klachten en meer persoonlijk/familiaire problemen ondervinden en een grotere arbeidsontevredenheid vertonen. Dit gaf aanleiding tot een vervolgonderzoek (Maloney en Bartz, 1983) warin beide groepen verpleegkundigen vergeleken worden op de drie kenmerken van "hardiness". De resultaten van dit onderzoek gaven aan dat:

- ICU-verpleegkundigen meer uitdaging zoeken dan niet-ICU-verpleegkundigen

- ICU-verpleegkundigen meer vervreemd zijn dan niet-ICU-verpleegkundigen

- ICU-verpleegkundigen meer extern en niet-ICU-verpleegkundigen meer intern georiënteerd zijn. 
Deze niet eenduidige resultaten tonen aan dat beide groepen, verpleegkundigen van rcu's en niet-ICU's, over een bepaalde mate van stress-tolerantie ("hardiness") beschikken.

\section{SAMENVATTING}

Onderzoeken die individuele/psychosociale kenmerken hebben geïnventariseerd zonder direct verbanden te leggen met andere variabelen (werkaspecten c.q. reacties) zijjn voornamelijk gericht geweest op copinggedrag en stresstolerantie van verpleegkundigen.

Een algemene bevinding in de onderzoeken naar coping is dat er een onderscheid gemaakt kan worden tussen de "directe actie mechanismen" en de "palliatieve strategieën". Eveneens is aangetoond door Maloney en Bartz (1983) dat zowel verpleegkundigen van intensieve als algemene verpleegafdelingen beschikken over een bepaalde mate van stresstolerantie ("hardiness").

\subsection{Onderzoek naar de relaties tussen werkaspecten en reacties}

In de vorige paragrafen zijn onderzoeken aan de orde geweest die hetzij de werksituatie van. verpleegkundigen hebben bestudeerd, hetzij reacties in kaart hebben gebracht, hetzij persoonlijkheidskenmerken hebben geïnventariseerd, Hiernavolgend komen aan de orde de studies naar verbanden tussen enerzijds werkaspecten en anderzijds reacties van verpleegkundigen.

\section{Stress-niveau}

Allereerst is een aantal onderzoeken gericht geweest op het achterhalen van relaties tussen stressoren en mogelijke reacties van verpleegkundigen. Zo liet het onderzoek van Gray-Toft en Anderson (1981a, 1981b) bij 122 verpleegkundigen uit een algemeen ziekenhuis zien dat de totale stress-score, gemeten met de "Nursing Stress Scale", negatief samenhangt met arbeidssatisfactie en positief gecorreleerd is met "trait anxiety" en "state anxiety". Bovendien bleek de stress-score een belangrijke bepalende factor te zijn ten aanzien van de hoogte van het verloop. Hoe hoger gescoord wordt op deze stress-score, des te hoger het verloop is.

Norbeck (1985a) vond vergelijkbare resultaten; de totale stress-score heeft een negatief verband met arbeidstevredenheid en een positieve correlatie met psychische symptomen (overigens niet nader gespecificeerd). Analyses op itemniveau lieten zien dat specifieke stressoren gerelateerd zijn aan beide reactie-variabelen. De volgende stressoren bleken negatief gerelateerd te zijn aan satisfactie: fysische omgeving van de afdeling, communicatieproblemen tussen verpleegkundigen onderling, werklast en hoeveelheid fysieke arbeid. Psychische symptomen hebben een positief verband met fysische omgeving, communicatieproblemen, tegemoetkomen aan psychische problemen van de patiënt, lawaai, verschillende soorten benodigdheden en gebreken en fysiek letsel van de verpleegkundigen.

\section{Rolstress}

In een andere groep onderzoeken zijn begrippen afkomstig uit de rolstress-theorie in verband gebracht met beleving en gedrag van verpleegkundigen. In zijn onderzoek bij 136 hoger opgeleide verpleegkundigen ("clinical nurse specialists") vond Johnson (1986) rolambiguïteit negatief gecorreleerd met tevredenheid met het werk zelf, met de leiding, met collega's, met salaris, met promotie en met algemene tevredenheid. Onder rolambiguïteit wordt verstaan de onduidelijkheid in rolopvattingen en rolverwachtingen (Zwaga, 1983). Van den Bergh-Braam 
(1984) trof in haar onderzoek bij hoofdverpleegkundigen positieve relaties aan tussen rolonduidelijkheid enerzijds en psychische klachten en verlies aan zelfwaardering anderzijds.

Dolman en Visser (1984) toonden een negatief verband aan tussen rolspanningen en arbeidssatisfactie bij leerlingverpleegkundigen.

De longitudinale studie van Bateman en Strasser (1983) attendeert op het verschil tussen correlationele en sequentionele verbanden ten aanzien van hun bevinding dat spanningen die het gevolg zijn van rolproblemen verband houden met algemene tevredenheid waarbij: de dimensies "tevredenheid met de leiding" en "het salaris" resultaten van spanningen blijken en de dimensies "tevredenheid met het werk" en "de artsen" aan spanningen vooraf gaan. In zijn onderzoek bij 246 leerling en gediplomeerde verpleegkundigen toonde Murray (1983) aan dat de mate van rolconflict inwloed heeft op de verloopgeneigdheid. Er is sprake van een rolconflict wanneer er een strijdigheid bestaat tussen opvattingen en verwachtingen omtrent wie welke taak of taken in een organisatie behoort uit te voeren (Zwaga, 1983).

Zwaga (1983) kwam voor een onderzoekspopulatie van 586 verpleegkundigen (leerlingen, gediplomeerden, afdelingshoofden) afkomstig uit 16 ziekenhuizen in Nederland tot een gelijksoortig resultaat. Rolproblemen (onder andere rolconflict en -ambiguiteit) vergroten de verloopgeneigdheid. Ook vond hij een verband tussen rolproblemen en satisfactie. Echter de rolproblemen bleken weinig of geen voorspellende waarde te hebben voor werkelijk verloop evenals voor verzuimfrequentie en -duur.

\section{Taakstructuur}

Onderzoek naar de invloed van kenmerken van de structuur van de taak op verschillende reacties van verpleegkundigen heeft geleid tot de volgende bevindingen. De variabelen "taakverruiming" (bestaande uit de dimensies": autonomie, taak-orientatie, duidelijkheid, innovatie en fysiek welbevinden) en "werkdruk" vertoonden in het onderzoek van Constable en Russell (1986) respectievelijk een negatief en positief verband met de mate van burnout. Samen met de variabele "steun van het afdelingshoofd", vormden deze variabelen de belangrijkste predictoren van burnout. De variabele "autonomie" wordt ook in andere onderzoeken aangemerkt als belangrijke voorspeller van tevredenheid (Weisman e.a., 1980; Dear e.a., 1982) en burnout (Stone e.a., 1984; Constable en Russell, 1986; Roelens, 1986). De positieve relatie tussen werkdruk (werkbelasting, werklast) en burnout wordt bevestigd door de onderzoeken van Norbeck (1985a), Roelens (1986) en McCranie e.a. (1987). Kosmoski en Calkin (1986) vonden dat tevredenheid met het werk, het afdelingshoofd, het salaris, promotie en collega's toeneemt naarmate de inbreng van de verpleegkundige in aan het werk gerelateerde beslissingen toeneemt en naarmate regels en procedures meer gestandaardiseerd zijn en als zodanig gevolgd worden. De mate van verantwoordelijkheid en de kwaliteit van de werkomstandigheden bleken in het onderzoek van Murro (1983) bij 329 gediplomeerde verpleegkundigen de belangrijkste voorspellers van satisfactie te zijn.

\section{Leiderschap}

Verscheidene onderzoeken hebben de invloed van het leiderschapsgedrag van het afdelingshoofd nader bestudeerd. Er wordt vaak onderscheid gemaakt tussen sociaal(-emotioneel) leiderschap ("consideration") en taakstructurerend leiderschap ("initiating structure"). Kenmerkend aan sociaal leiderschap is dat de leider aandacht besteed aan het comfort, het welzijn en de arbeidsvoldoening van zijn ondergeschikten. Taakstructurerend leiderschap wordt door House en Baetz (1979) als volgt omschreven: "de leider definieert en verduidelijkt haar of zijn rol en laat de ondergeschikten weten wat van hen verwacht wordt". Naast sociaal- en taakgericht 
leiderschap wordt ook vaker het produktiegericht leiderschap onderscheiden, dat door Stogdill (1963) als volgt kort wordt omschreven: "de leider legt nadruk op produktie" "De dimensie instrumenteel leiderschap van Philipsen (1965) bestaat uit een combinatie van zowel kenmerken van taakstructurerende als produktiegericht leiderschap.

Pryer en Distefano (1971) onderzochten thet effect van leiderschapsgedrag op drie groepen verplegenden; 39 verpleeghulpen, 40 psychiatrische hulpen en 20 gediplomeerde verpleegkundigen. Daarbij bleek dat sociaal leiderschap, voor deze drie groepen afzonderlijk, positief gerelateerd is aan verschillende dimensies van arbeidssatisfactie. Taakstructurerend leiderschap bleek slechts voor de verpleeghulpen positief samen te hangen met de dimensie tevredenheid met collega's en voor de psychiatrische hulpen met tevredenheid met de leiding. Ook Zwaga (1981) concludeerde voor een landelijke steekproef van verpleegkundigen in Nederland dat sociaal-emotioneel leiderschap een bijdrage kan leveren aan de verhoging van voornamelijk satisfactie met de leiding. Instrumenteel leiderschap daarentegen bleek weinig tot geen effect op tevredenheidsaspecten te hebben. De invloed van beide leiderschapsstijlen op rolproblemen was vrij beperkt. De bevindingen van Cassee e.a. (1965) komen overeen met die van Zwaga (1981) in die zin dat sociaal leiderschap positief gecorreleerd is met tevredenheid met de chef en instrumenteel leiderschap geen effect bleek te hebben.

In het onderzoek van Duxbury e.a. (1984) bij een steekproef van 283 verpleegkundigen werkzaam op Neonatal Intensive Care Units bleek taakstructurerend leiderschap eveneens geen verband te hebben noch met satisfactie noch met burnout. Sociaal leiderschap vertoonde wel redelijke samenhangen, namelijk met satisfactie positief en met burnout negatief. Bovendien onderzochten Duxbury e.a. de invloed van verschillende combinaties van sociaal en taakstructurerend leiderschap. Zo bleken de verpleegkundigen de hoogste mate van burnout en ontevredenheid te ervaren wanneer het afdelingshoofd weinig sociaal en veel taakstructurerend leiderschap vertoonde. Ook stelden de onderzoekers vast dat, wanneer het afdelingshoofd hoog scoorde op sociaal leiderschap burnout en satisfactie positief beïnvloed werden, onafhankelijk van de score van het hoofd op taakstructurerend leiderschap. Het onderzoek van Gruenfeld en Kassum (1973) echter toonde aan dat afdelingshoofden die veel aandacht besteden aan zowel de sociale als de taakstructurende aspecten in hun leidinggeven het best in staat zijn een hoge mate van arbeidsvoldoening bij de verpleegkundigen te bewerkstelligen. Reeds in 1967 rapporteerde Cassee dat de verzuimfrequentie van verpleegkundigen afneemt naarmate het afdelingshoofd meer sociaal leiderschapsgedrag vertoont, overigens zonder dat dit leiderschapsgedrag invloed bleek te hebben op de verzuimduur.

\section{Verpleegsysteem}

Een aantal studies heeft afdelingen die verplegen volgens het principe van "primary nursing" vergeleken met afdelingen die niet op deze manier hun patiënten verplegen. "Primary nursing" is een manier van verplegen die wordt gekenmerkt door toewijzing van patiënten aan verpleegkundigen die verantwoordelijk zijn voor de totale zorg van de aan hen toegewezen patiënten. De methode van "primary nursing" wordt in de Verenigde Staten vaak afgezet tegen de meer traditionele functionele methode van taaksplitsing en taaktoewijzing ("functional nursing"). Alexander e.a. (1981) vergeleken 32 "primary" en 20 "non-primary units" op satisfactie, verzuim en verloop. Er werden geen verschillen tussen de twee typen afdelingen gevonden wat betreft de arbeidswoldoening. Wel bleek dat de "primary units" een lager verzuim en verloop vertoonden.

Sellick e.a. (1983) vonden wel een grotere satisfactiebeleving bij verpleegkundigen op "primary care units" dan bij verpleegkundigen die op "non-primary care units" werkzalam zijn. Uit 
anialyses op itemniveau bleek dat de hogere mate van tevredenheid wooral voortkomt uit het feit dat "primary care"-verpleegkundigen vinden dat ze meer gelegenheid hebben iets waardevols te bereiken, eerder de mogelijkheid hebben hun mening kenbaar te maken en een bijdrage te leveren in beslissingen en zelf bèt werktempo kunnen bepalen. Een ander resultaat in dit onderzoek was dat patiénten die verpleegd werden op "primary units" meer tevreden waren met de verleende zorg dan patiënten op "non-primary units". Shukla en Turner (1984) echter vonden geen verschil in satisfactie van de patiênten op een afdeling die "primary care" toepast en die op een afdeling die uitgaat van het Amerikaanse "team nursing" (functionele verpleging in teams). Ook in Nederland is het effect van de werkorganisatie op de beleving van de verpleegkundigen nagegaan. Uit een onderzoek verricht onder toezicht van de Nationale Ziekenhuisraad (NZR, 1979 ) bleek dat de Nederlandse teamverpleging (groepsverpleging op basis van patiëntentoewijzing) tot meer tevredenheid onder de verpleegkundigen leidt en de verpleegkwaliteit bevordert. De resultaten van de onderzoeken van Mercx (1975b) en Boekholdt (1981) bevestigen de bevindingen van het NZR; invoering van groepsverpleging leidt tot meer tevredenheid onder de verpleegkundigen. Uit het verslag van een tweejarig experiment in het Academisch Ziekenhuis Groningen (AZG, 1986) bleek dat Integrerende Verpleegkunde, eveneens een verpleegvorm waarin patiëntentoewijzing centraal staat, de betrokkenheid, motivatie, zelfstandigheid en werkbevrediging van de verpleegkundige en de leidinggevende vergroot.

\section{Organisatieklimaat, communicatie en technologie}

De laatste drie onderzoeken die besproken zullen worden hebben betrekking op de finvloed van het organisatieklimaat, de communicatie en de technologie. Het onderzoek van Duxbury e.a. (1982) voor een steekproef van 18 NICU's liet zien dat drie van de zes schalen van de "Nursing Organizational Climate Description Questionnaire" gerelateerd waren aan arbeidssatisfactie, namelijk "humanistic thrust" ${ }^{\text {t" }}$ ) en "esprit" correleerden positief met tevredenheid en "disengagement" was negatief gerelateerd aan tevredenheid.

Pincus (1986) vond dat bepaalde aspecten van communicatie (communicatie met de leiding, communicatieklimaat, persoonlijke feedback, en communicatie met het top management) een positieve bijdrage leveren aan de arbeidsvoldoening van de verpleegkundigen en in mindere mate aan de taakuitwoering.

Uit het onderzoek van Gray (1984) tenslotte kwam naar voren dat technologie (instabiliteit, onzekerheid, gevarieerdheid) slechts een gering verband heeft met verschillende dimensies wan arbeidsvoldoening.

\section{SAMENVATTING}

In deze paragraaf zijn onderzoeken besproken naar mogelijke verbanden tussen werkaspecten (stress-niveau, rolproblemen, taakverruiming, werkdruk, autonomie, participatie in beslissingen, standaardisatie, verantwoordelijkheid, leiderschapsgedrag, verpleegsysteem, organisatieklimaat, communicatie, technologie) en reacties van verpleegkundigen (effecten zoals satisfactie, angst, verloopgeneigdheid, verloop, verzuim, burnout). Het merendeel van de onderzoeken was van transversale aard, met uitzondering wellicht van de longitudinale studie van Bateman en Strasser (1983). De onderzoeken zijn verricht bij zowel verpleegkundigen van ICU's als van andere verpleegafdelingen. 


\subsection{Onderzoek naar de invloed van individuele/psychosociale kenmerken (op reacties of op de relaties tussen werkaspecten en reacties)}

Voor de verschillende functies die een derde variabele in sociaal-wetenschappelijk onderzoek kan aannemen wordt verwezen naar Drenth (1980). Bij de bestudering van het gebruik van de derde variabele in onderzoek naar werkaspecten en reacties in de verpleging bleek dat hoofdzakelijk de invloed van individuele/psychosociale kenmerken als derde variabele is onderzocht. Deze verschillende variabelen en hun correlaten zullen nu besproken worden.

\section{Sociale ondersteuning}

De meeste aandacht in onderzoek in de verpleging is besteed aan de invloed van sociale ondersteuning, waarbij deze psychosociale variabele ofwel in een direct hoofdeffect op reacties van verpleegkundigen is gebruikt, ofwel is gekeken naar de modererende functie van sociale ondersteuning in de veronderstelling dat deze variabele in staat is de negatieve invloed van stressoren op stressreacties af te zwakken.

Een aantal onderzoekers heeft het hoofdeffect van sociale ondersteuning op mogelijke reactievariabelen onderzocht. Zo bleek er een directe positieve relatie tussen sociale steun en satisfactie (Norbeck, 1985b; Peiro e.a., 1986). Een negatieve relatie werd gevonden met: burnout (Cronin-Stubbs en Rooks, 1985; Roelens, 1986; Constable en Russell, 1986), emotionele uitputting en depersonalisatie (Firth, 1986), verloopgeneigdheid (Firth, 1986; Peiro e.a., 1986) en psychische symptomen (Norbeck, 1985b).

In meerdere onderzoeken is de modererende functie van ondersteuning onderzocht. In het onderzoek van Peiro e.a. (1986) bleek structurele sociale ondersteuning geen buffereffect te hebben. Functionele sociale steun zwakte enkel de negatieve bijdrage van rolconflict op tevredenheid af. In hun analyse van 36 mogelijke interactie-effecten vonden Constable en Russell (1986) slechts een modererend effect van ondersteuning van de leiding op de relatie tussen taakverruiming en emotionele uitputting; bij een toename van steun van de leiding verdwijnt de negatieve relatie tussen takkverruiming en emotionele uitputting.

Norbeck (1985b) en Roelens (1986) konden niet aantonen dat sociale ondersteuning de relatie tussen werkstress en burnout, satisfactie en psychische symptomen afzwakt of versterkt.

\section{Coping}

Albrecht (1982) bestudeerde de invloed van het gebruik van bepaalde copingstrategieën op de mate van burnout. De resultaten lieten zien dat twee strategieën, namelijk zich terugtrekken van anderen en overwegen van werk te veranderen, de sterkste positieve correlaties met symptomen van burnout vertoonden. Strategieën die negatief gerelateerd waren aan burnout waren: praten met de leidinggevende, godsdienstoefeningen, het opzoeken van collega's van de afdeling. Bovendien werd in deze studie nagegaan of verpleegkundigen die een hoge mate van burnout ervaren van andere copingstrategieën gebruik maken dan verpleegkundigen met een lage ervaren burnout. Een opvallend resultaat was dat de hoge-burnout-groep meer gebruik maakte van zogenaamd vluchtgedrag ("flight") (overmatig eten, overwegen van baan te veranderen, praten met vrienden/verwanten), terwijl de lage-burnout-groep strategieën hanteerde waaruit de betrokkenheid in het werk en de werkomgeving duidelijk bleek (de aard van het probleem overdenken, praten met andere verpleegkundigen die in dezelfde situatie verkeren, leidinggevende om hulp vragen, lichaamsbeweging). 


\section{Hordiness"}

Keane ea (1985) toonden voor een groep van 96 1CU en niet-ICU verpleegkundigen aan dat er een verband bestaat twssen de mate van "hardiness" en burnout; verpleegkundigen die meer extern georienteerd zijn, meer vervreemding van het werk en zichzelf ervaren en zich machteloos voelen, ervaren een grotere mate van burnout. McCranie e.a. (1987) kwamen tot eenzelfde resultat. Bovendien vonden zij dat werkstress (voornamelijk werklast) en de mate van "hardiness" als additieve en niet als interactieve predictoren van burnout beschouwd moeten worden. Met andere woorden, de variabele "hardiness" bleek een hoofd-effect en geen buffer-effect op burnout te hebben.

\section{BIOGRAFISCHE KENMERKEN}

\section{Leeftijd}

Uit een aantal onderzoeken kwam naar voren dat leeftijd niet significant bijdraagt aan satisfactie (Huckabay en Jagla, 1979; Leatt en Schneck, 1980; Dear e.a., 1982; Sanger e.a., 1985). In het onderzoek van Keane e.a. (1985) bleken oudere verpleegkundigen lagere burnoutscores te hebben dan hun jongere collega's. Bovendien kwam uit het onderzoek van Floor (1976) naar voren dat het verloop onder jongeren hoger is dan onder ouderen. Dit stemt overeen met het gevonden verband tussen verloop en leeftijd in de studie van Dear e.a. (1982). Een andere bevinding in het onderzoek van Floor (1976) was dat het verzuimpercentage (het aantal verzuimdagen per 100 dagen) hoger is bij oudere verpleegkundigen, terwijl de verzuimfrequentie (het aantal verzuimgevallen per persoon) bij ouderen juist lager is.

\section{Opleiding}

In het onderzoek van Hall e.a. (1981) bleken hoger opgeleiden meer tevreden met verschillende aspecten van het werk, zoals autonomie, salaris, prestige en interactie, dan lager opgeleiden. Echter zowel in het onderzoek van Dear e.a. (1982) als in het onderzoek van Sanger e.a. (1985) bleek opleidingsniveau in de regressie-vergelijking geen predictor van satisfactie.

Het verloop onder hoger opgeleiden is in de studie van Gray-Toft en Anderson (1981a) hoger, in de studie van Dear e.a. (1982) lager en Lemler en Leach (1986) vonden geen verschil op deze variabele tussen hoger en lager opgeleiden.

Ten aanzien van verzuim wordt tenslotte gevonden dat een hogere opleiding samengaat met een lagere verzuimfrequentie (Barr, 1967; Clark, 1975). Floor (1976) kwam echter tot een tegengesteld resultat.

\section{Dienstrijd}

De invloed van diensttijd op reacties van verpleegkundigen is bij herhaling onderzocht. Zo vonden Hall e.a (1981) dat de meest tevreden verpleegkundigen diegenen zijn die minder dan een jaar en langer dan vijf jaar in dezelfde functie werkzaam zijn. Een lineaire relatie tussen diensttijd en satisfactie werd gevonden ten aanzien van de dimensies: tevredenheid met taakbenodigdheden en tevredenheid met autonomie.

Steeds weer blijkt dat naarmate men langer in dienst is men meer tevreden is met het werk (Nichols e.a., 1981; Gray, 1984; Norbeck, 1985b; Simpson, 1985; Bryson e.a., 1985) en minder psychische symptomen vertoont (Norbeck, 1985b). Dit zou ons inziens te maken kunnen hebben met een selectie-effect: verpleegkundigen die ontevreden zijn en psychische klachten hebben vertrekken voortijdig wit hun functie. 
Ten aanzien van de variabele "verloop" wordt gevonden dat degenen die kort in dienst zijn een groter verloop hebben (Floor, 1976, Weisman e.a., 1981). Floor (1976) en Clark (1975) tensllotte melden dat de verzuimfrequentie hoger is bij een langere diensttijd. Jamal (1981) kwam tot een tegengesteld resultaat.

Een opmerking die gemaakt moet worden is dat veel studies die het effect van diensttijd bestudeerd hebben geen melding maken van de soort diensttijd die onderzocht is. Men kan namelijk een onderscheid maken tussen diensttijd in de verpleging, in het ziekenhuis en op de verpleegafdeling.

\section{Soort aanstelling}

De soort aanstelling die men heeft zou de uiteindelijke reactie van de verpleegkundige op het werk mede kunnen bepalen. In de verpleging, waarvoor kenmerkend is dat gewerkt wordt in ploegendiensten, kan onderscheid gemaakt worden tussen verpleegkundigen die alle diensten draaien en verpleegkundigen die vaste werktijden hebben. Bovendien kan men verpleegkundigen onderscheiden die een partime en een fulltime aanstelling hebben. Onderzoeken in de verpleging die fulltimers en parttimers op bijvoorbeeld hun arbeidsvoldoening en ziekteverzuim vergelijken zijn ons onbekend. Wel is onderzoek verricht naar het effect van werken in vaste of wisselende diensten. Zo bleek uit het onderzoek van Jamal (1981) dat verpleegkundigen die in wisselende onregelmatige diensten werken een grotere verloopgeneigdheid vertonen dan hun collega's die steeds op vaste tijden werkzaam zijn. De bevindingen van Colligan e.a. (1979) liggen op dezelfde lijn; verpleegkundigen met wisselende diensten zijn vaker ziek dan verple egkundigen met een vaste dienstregeling. Norbeck (1985b) tenslotte vond dat verpleegkundigen die uitsluitend nachtdiensten draaien minder tevreden zijn met hun werk dan verpleegkundigen waarvoor een andere dienstregeling geldt.

\section{Geslacht}

De bevinding van Simpson (1985) dat mannelijke verpleegkundigen meer tevreden zijn met hun werk dan hun vrouwelijke collega's kon door Van den Bergh-Braam (1984) in haar onderzoek bij hoofdverpleegkundigen niet bevestigd worden; zij vond geen significante samenhang tussen geslacht en satisfactie. Wel toont het onderzoek van Dassen (1989) bij psychiatrisch verpleegkundigen aan dat mannen significant hoger scoren dan vrouwen op twee van de drie dimensies van burnout, namelijk emotionele uitputting en depersonalisatie.

\section{SAMENVATTING}

In arbeidsstudies betreffende de relatie tussen verpleegkundigen en hun werk blijken derde variabelen vaak een belangrijke bijdrage te leveren aan de viteindelijke reactie op dat werk. Deze bijdrage kan plaatsvinden in een direct hoofd-effect of een buffer(moderator)-effect. De modererende functie van derde variabelen is voornamelijk onderzocht voor de variabelen sociale ondersteuning en de mate van "hardiness". Op dit moment is te weinig onderzoek verricht naar deze modererende functie van persoons- en psychosociale kenmerken om een voldoende onderbouwde uitspraak te doen over een dergelijke rol van sociale ondersteuning, "hardiness" of welke andere derde variabele dan ook. Van de volgende persoonsvariabelen blijkt het hoofdeffect op andere variabelen te zijn onderzocht: copingstrategieën (op burnout); leeftijd (op satisfactie, verloop, verzuim); opleidingsniveau (op tevredenheid, verloop, verzuim); diensttijd (op tevredenheid, psychische symptomen, verloop, verzuim); vaste/wisselende diensten (op verloopgeneigdheid, verzuim, satisfactie); geslacht (op satisfactie). 


\subsection{Conclustes}

\section{Stand wan zaken}

$\mathrm{Er}$ is sprake van een groeiende belangstelling bëj verplegings- en gedragswetenschappers voor empirisch en kwantitatief onderzoek naar het werk en de werkbeleving van verpleegkundigen. Deze omwenteling in de omvang maar vooral de aard van het onderzoek toont een vooruitgang ten aanzien van de vroegere beschrijvingen van verpleegkundigen, artsen en leidinggevenden die gebaseerd waren op subjectieve beoordelingen en observaties. Deze wetenschappelijke belangstelling voor het onderwerp heeft er echter niet toe geleid dat men in de onderzoeken uitgaat van gedegen en gangbare theorieên, aangezien het merendeel van de studies a-theoretisch van aard is. Een uitzondering hierop vormen wellicht een aantal onderzoeken die in Nederland zijn opgezet vanuit de roltheoretische benadering (Zwaga, 1983; Van den BerghBraam, 1984).

De wijdverspreide veronderstelling dat intensieve verpleging "stressvoller" is dan de meer algemene verpleging wordt vooralsnog niet met empirische gegevens bevestigd. Veel studies zijn enkel gericht op de werksituatie van de ICU. Vergelijkend onderzoek tussen de intensieve en algemene verpleging naar bronnen van stress en tevredenheid laten tegenstrijdige resultaten zien. Ditzelfde geldt voor de onderzoeken die de stressreacties van ICU- en niet-ICU-verpleegkundigen hebben vergeleken. Mogelijke verklaringen hiervoor zijn wellicht te vinden in de verschillen in gehanteerde meetinstrumenten en onderzoekspopulaties.

Tot nu toe hebben de meeste onderzoeken zich gericht op het in kaart brengen van 6fwel de werkaspecten 6fwel de stressreacties. Te weinig studies hebben geprobeerd percepties van de verpleegkundige werkomgeving en de eisen die aan de verpleegkundigen worden gesteld in verband te brengen met mogelijke reacties van verpleegkundigen zoals de mate van burnout, arbeidstevredenheid, gezondheidsklachten, taakuitvoering, verloop en verzuim. Een stresserende werksituatie hoeft namelijk niet per se tot een negatieve outcome te leiden. Andere, meer persoonsgebonden en psychosociale factoren kunnen mede een rol spelen bij het tot stand komen van de uiteindelijke reactie die verpleegkundigen op hun werk vertonen.

Onderzoeken waarmee beoogd werd verbanden aan te tonen tussen aspecten in het werk en reactie-variabelen hebben zich vaak beperkt tot een of slechts enkele werkaspecten. De relatieve en samenhangende invloed van meerdere variabelen is nauwelijks onderzocht.

Op basis van de literatuurstudie kan geconcludeerd worden dat er te weinig aandacht besteed is aan de invloed en werking van individuele en psychosociale variabelen die als derde variabele een rol kunnen spelen in de vorm van een hoofd- en/of buffereffect. Vooral is nagelaten dergelijke factoren in de functie van moderator-variabelen te onderzoeken.

In weel van de genoemde studies is een aanzienlijk aantal methodologische problemen te signaleren. Men beperkt zich vaak tot willekeurig gekozen en kleine onderzoekspopulaties, afkomstig van één of slechts enkele verpleegafdelingen binnen één of enkele ziekenhuizen; slechts weinig onderzoeken hebben gebruik gemaakt van gerandomiseerde steekproeven, met alle gevolgen ten aanzien van de beperking van de generaliseerbaarheid van de bevindingen vandien. Ook zijn de gebruikte meetinstrumenten niet altijd gevalideerd, noch gestandariseerd. Bovendien wordt in een aantal onderzoeksartikelen gén of slechts summier melding gemaakt van de opzet en uitvoering van het onderzoek en de validiteit en betrouwbaarheid van de vragenlijsten, hetgeen een kritische beoordeling van de kwaliteit van de onderzoeken dan onmogelijk maakt. 
Aandachtspunten voor het onderhavige onderzoek

Voor het onderhavige onderzoek kunnen op grond wan de verrichte literatuurstudie een aantal aandachtspunten geformuleerd worden.

Om tot een opsporing van knelpunten en problemen in de verpleegkundige werksituatie te komen zal niet alleen een analyse van verschillende aspecten van het werk en mogelijke reacties bij verpleegkundigen dienen plaats te vinden, maar zal ook getracht moeten worden verbanden tussen aspecten van het werk en reacties van verpleegkundigen te achterhalen. Bovendien zal aandacht besteed moeten worden aan de invloed van persoonsgebonden en psychosociale factoren, waarbij nagegaan wordt of er sprake is van een hoofd- of buffereffect. Door zowel werkaspecten als individuele en psychosociale factoren bij het onderzoek te betrekken kan nagegaan worden op welk terrein toekomstige interventies kansrijk zijn. Afhankelijk van de resultaten van het onderzoek kunnen aan de ene kant bijwoorbeeld structurele veranderingen aanbevolen worden in het werk zelf, zoals veranderingen in de taak, de structuur en organisatie van de afdeling. Aan de andere kant kunnen interventies aangewezen lijken met betrekking tot kenmerken van de verpleegkundigen, zoals het aanleren van effectieve copingstrategieën. Eveneens kan ingegrepen worden in de meer psychosociale kenmerken, zoals het verbeteren van het sociale ondersteuningssysteem op een afdeling.

Om de bestaande veronderstelling na te gaan dat intensieve verpleging meer stresssituaties herbergt dan de niet-intensieve meer algemene verpleging en dat intensive care-verpleegkundigen meer negatieve reacties vertonen op hun werk dan verpleegkundigen van algemene afdelingen, lijkt het zinvol beide typen afdelingen in het onderzoek te betrekken en te vergelijken. Dit maakt het mogelijk uitspraken te doen over de werksituatie en de reacties van zowel verpleegkundigen van intensieve als van meer algemene verpleegafdelingen. In het kader van deze vergelijking hebben verpleegkundigen van beide typen verpleegafdelingen deel uitgemaakt wan de onderzoekspopulatie van de onderhavige studie (zie 4.3). Over de resultaten van deze vergelijking zal elders worden gerapporteerd.

Voor de onderzoeksontwikkeling in de verpleging is het van belang dat men tot een gedegen theoretische onderbouwing komt. Aan het theoretisch kader van het onderhavige onderzoek zal uitgebreid aandacht besteed worden in het volgende hoofdstuk.

\section{NOTEN}

1) $\mathrm{ICU}=$ Intersive Care Unit, $\mathrm{CCU}=$ Cardiac Care Unit; Hartbewakingsafdeling, IC-CCU = Intensive Care Unit en Cardiac Care Unit gecombineerd.

2) Voor een omschrijving van deze verpleegsystemen zie 2.5 en 4.5.2.3.

3) "Humanistic thrust" is de mate waarin het gedrag van de leider gekenmerkt wordt door pogingen haar/zijn ondergeschikten te motiveren door een persoonlijk voorbeeld te stellen. "Esprit" is de mate waarin de ondergeschikten het gevoel hebben dat hun sociale behoeften bevredigd worden en ze iets tot stand brengen in hun werk. "Disengagement" is de mate waarin de ondergeschikten niet betrokken zijn bij de door hen uit te voeren taken. 


\section{DE THEORETISCHE ACHTERGROND VAN HET ONDERZOEK}

\subsection{Inleiding}

Het vorige hoofdstuk is afgesloten met de belangrijke opmerking dat onderzoek naar de relatie tussen arbeid en reacties van werknemers in het veld van de verpleging in grotere mate aansluiting zou moeten zoeken met gangbare theorieên en modellen. Vandaar dat in dit hoofdstuk uitgebreid aandacht zal worden besteed aan de keuze van de theoretische achtergrond van het onderhavige onderzoek.

Allereerst zal nader ingegaan worden op de ontwikkelingsgeschiedenis van denken over arbeid. Hierin neemt het principe van de arbeidsdeling een belangrijke plaats in. Het uitgangspunt van arbeidsdeling en vereenvoudiging van taken, dat zijn grondslag vindt in het werk van Adam Smith (1776; zie Van Assen en Den Hertog, 1980), werd in een ver doorgevoerde vorm toegepast door Taylor (1911; zie Van Assen en Den Hertog, 1980) in zijn wetenschappelijke aanpak van de organisatie van de arbeid ("Scientific Management"). De algemene verwachting van deze benadering was dat de invoering van een "horizontale" en "verticale" deling van taken zou leiden tot verhoging van de arbeidsproduktiviteit samengaande met een verlaging van de produktiekosten en verbetering van de beheersing van het produktieproces door het management (Van Assen en Den Hertog, 1980).

Echter al snel werd duidelijk dat vereenvoudigde en routinematige arbeid een negatieve invloed had op de arbeidstevredenheid en het verloop en verzuim van de werknemers, wier invloed op het werk vrijwel geheel verdwenen was (Hackman en Lawler, 1971).

Als reactie op deze misstanden deden omstreeks 1930 stromingen (onder andere "Human Relations", "Revisionisme") hun intrede die de benadering wan de werkende mens als een sociaal wezen met $z$ 'n individuele behoeften centraal stelden (Van Assen en Den Hertog, 1980; Van Strien, 1980).

Langzamerhand ontstond een traditie die erop gericht was (en is) factoren in de werksituatie te achterhalen die van invloed zijn op reacties van werknemers zoals arbeidsmotivatie en -satisfactie. De aanzet tot deze traditie is te vinden in het werk van Maslow (1954) en Herzberg e.a. (1959). Vooral de Twee-factor theorie van Herzberg e.a. is van belang geweest, omdat deze de aandacht vestigde op het onderscheid tussen de taakintrinsieke aspecten van het werk (bijvoorbeeld verantwoordelijkheid, groei, ontwikkeling) die vooral zouden samenhangen met gevoelens van tevredenheid en motivatie en de taakextrinsieke factoren (bijvoorbeeld manier van leidinggeven, werkomstandigheden, beloning) die vooral van invloed zouden zijn op dissatisfactie.

Ondanks het feit dat in verschillende onderzoeken deze theorie niet kon worden bevestigd, heeft het werk van Herzberg e.a. de aanleiding gevormd voor ontwikkelingen die benoemd worden als werkherstucturering, kwaliteitsverbetering van de arbeid en humanisering van de arbeid. Deze ontwikkelingen beoogden terugdringing van de arbeidsdeling en vergroting van de verantwoordelijkheid, medezeggenschap en controle van werknemers over hun arbeidsactiviteiten. 
In aansluiting op Herzberg e.a. zijn verschillende theorieën en modellen ontwikkeld aangaande de relatie tussen kenmerken van werk en reacties van taakuitvoerders. Voor een uitgebreid overzicht hiervan wordt verwezen naar het proefschrift van Algera (1981).

De meest gangbare benadering binnen de richting van taakontwerp ("job design") tot nu toe is het "Job Characteristics Model" (JCM) van Hackman en Oldham (1975, 1976). Dit model is gebaseerd op het werk van Turner en Lawrence (1965) en Hackman en Lawler (1971). Het model is geen geheel nieuw uitgangspunt op het gebied van taakontwerp, maar vormt een bundeling van een woorafgaande onderzoekslijn die zich uitstrekt over een periode van meer dan 15 jaar (Wall en Martín, 1987).

In dit hoofdstuk zal het JCM nader besproken worden aangezien dit model het theoretisch uitgangspunt heeft gevormd van het onderzoeksmodel dat in deze studie gehanteerd wordt bij het beschrijwen wan relaties tussen aspecten van verpleegkundig werk en reacties van verpleegkundigen daarop (zie hoofdstuk 4).

De keuze voor het JCM heeft te maken met de ontstaansgeschiedenis van het model die een reactie vormde op de problemen die voorkwamen in organisaties opgezet volgens de Tayloriaanse werkmethode. Een belangrijk aandachtspunt in de benadering van "Scientific Management", de arbeidsdeling, wordt ook aangetroffen in de organisatie van het werk in de verpleging (functionele verpleging). Ook verpleegkundige taken worden veelal verdeeld zodat iedere verplegende opdracht krijgt én of meerdere specifieke handelingen te verrichten bij alle daarvoor in aanmerking komende patiënten. Het werk van Hackman en Oldham zou belangrijke aangrijpingspunten kunnen bieden voor werkherstructureringsprojecten en interventies in de verpleegkundige praktijk die aandacht besteden aan de negatieve gevolgen van de verdoorgevoerde taaksplitsing in de verpleging. Bovendien is het JCM onderwerp van vele studies geweest, waarbij inzicht is verkregen in de positieve en negatieve kanten van het model.

In de volgende paragrafen zal achtereenvolgens een beschrijving gegeven worden van de achtergrond van het JCM en zal het model in zijn huidige formulering gepresenteerd worden (3.2), zal een bespreking plaatsvinden van onderzoek naar de geldigheid van het "Job Characteristics Model" (3.3) en zal in een nabeschouwing nader ingegaan worden op knelpunten die in een eventuele herformulering van het model de aandacht verdienen (3.4).

\subsection{Achtergrond en beschrijving van het "Job Characteristics Model"}

Onderzoek naar "objectieve" kenmerken van werk gaat terug tot het werk van Turner en Lawrence (1965). Deze auteurs ontwikkelden een instrument voor het meten van een aantal taakkenmerken waarvan voorspeld werd dat ze positief gerelateerd zouden zijn aan reacties van taakuitvoerders zoals arbeidstevredenheid en verzuim. Op grond van een literatuuronderzoek en een a priori opgesteld beschrijvend model kwamen ze tot de afbakening van de volgende zes "requisite task attributes" (vereiste taakkenmerken):

1. variety (gevarieerdheild)

2. autonomy (autonomie)

3. required interactions (vereiste contacten)

4. optional interactions (mogelijkheid tot, of beperking van contacten)

5. knowledge of skills (benodigde inleertijd)

6. responsibility (verantwoordelijkheid). 
Turner en Lawrence ontwikkelden 18 schalen om deze 6 takkenmerken in katart te brengen. Voor 47 functies binnen 11 organisaties werden scores op de schalen verkregen met behulp van observaties en interviews verricht door de onderzoekers. Daar de zes taakkenmerken onderling vrij hoog gecorreleerd waren, werd een enkele gewogen totaalscore berekend (de "Requisite Task Attributes Index"; RTA-index). Naast deze "requtsite task attributes" onderscheidden Turner en Lawrence enkele "associated task attributes", waarvan "task identity" het voornaamste taakkenmerk vormt.

Uit de resultaten van de studie van Turner en Lawrence kwamen subculturele verschillen naar voren, aangezien de verwachting van een positieve (respectievelijk negatieve) relatie tussen banen die hoog scoorden op de RTA-index en de tevredenheid en het verzuim van de werknemers, alleen bleek op te gaan voor mensen die in kleinere steden werkten. Voor werkers in grotere steden werd een negatief verband gevonden tussen de RTA-index en arbeidssatisfactie en geen verband tussen de index en verzuim. Vervolgonderzoek van Hulin en Blood (1968) verschaft ondersteuning van de veronderstelling dat subculturele factoren van invloed zijn op de reacties van werknemers op hun werk.

De studie van Hackman en Lawler (1971) ondersteunt de these dat taakkenmerken de attitude en het gedrag van werknemers beïnvloeden. In tegenstelling tot Turner en Lawrence gingen deze onderzoekers wel uit van een theorie, namelijk de "Expectancy Theory" (Vroom, 1964; Porter en Lawler, 1968). Deze theorie heeft als uitgangspunt dat de mate van inspanning bepaald wordt door het produkt van (A) de aantrekkelijkheid van de opbrengst van de inspanning, en (B) de verwachting dat het arbeidsgedrag inderdaad tot de opbrengst leidt. Bepaalde aspecten van het werk bevorderen de perceptie dat goede prestaties leiden tot gevoelens van zelfwaardering: werknemers zullen daarom positief reageren op vier kerndimensies, te weten "variety", "task identity", "autonomy" en "feedback" (overgenomen van Turner en Lawrence, 1965). Naast deze vier kerndimensies onderscheiden ze de dimensies "dealing with others" en "friendship opportunities" ten aanzien waarvan echter geen specifieke verwachtingen over de effecten werden geformuleerd. Een toevoeging door Hackman en Lawler was de veronderstelling dat mensen met een hoge "growth need strength", GNS, (groeibehoefte; de behoefte aan persoonlijke groei en ontwikkeling in het werk), positiever zullen reageren op werk dat hoog scoort op de kerndimensies, aangezien ze het meest de kansen en intrinsieke beloningen die complexe banen bieden, zullen waarderen. Zij ontwikkelden de "Yale Job Inventory" om de verschillende variabelen te meten (Hackmari en Lawler, 1971).

Een essentieel verschil in de theoretische opvattingen van Turner en Lawrence (1965) en Hackman en Lawler (1971) is dat bij de laatstgenoemden de reacties van de werknemers bepaald worden door de perceptie van de taak door de werknemers zelf, terwijl bij Turner en Lawrence de taakkenmerken worden bepaald op grond van observaties van de onderzoekers. In 3.3.4 zal op de verschillende gezichtspunten ten aanzien van beide meetmethoden nader ingegaan worden.

Het later door Hackman en Oldham $(1975,1976)$ ontwikkelde "Job Characteristics Model" dat gebaseerd is op het werk van Turner en Lawrence (1965) en Hackman en Lawler (1971) wordt gepresenteerd in figuur 3.1. 


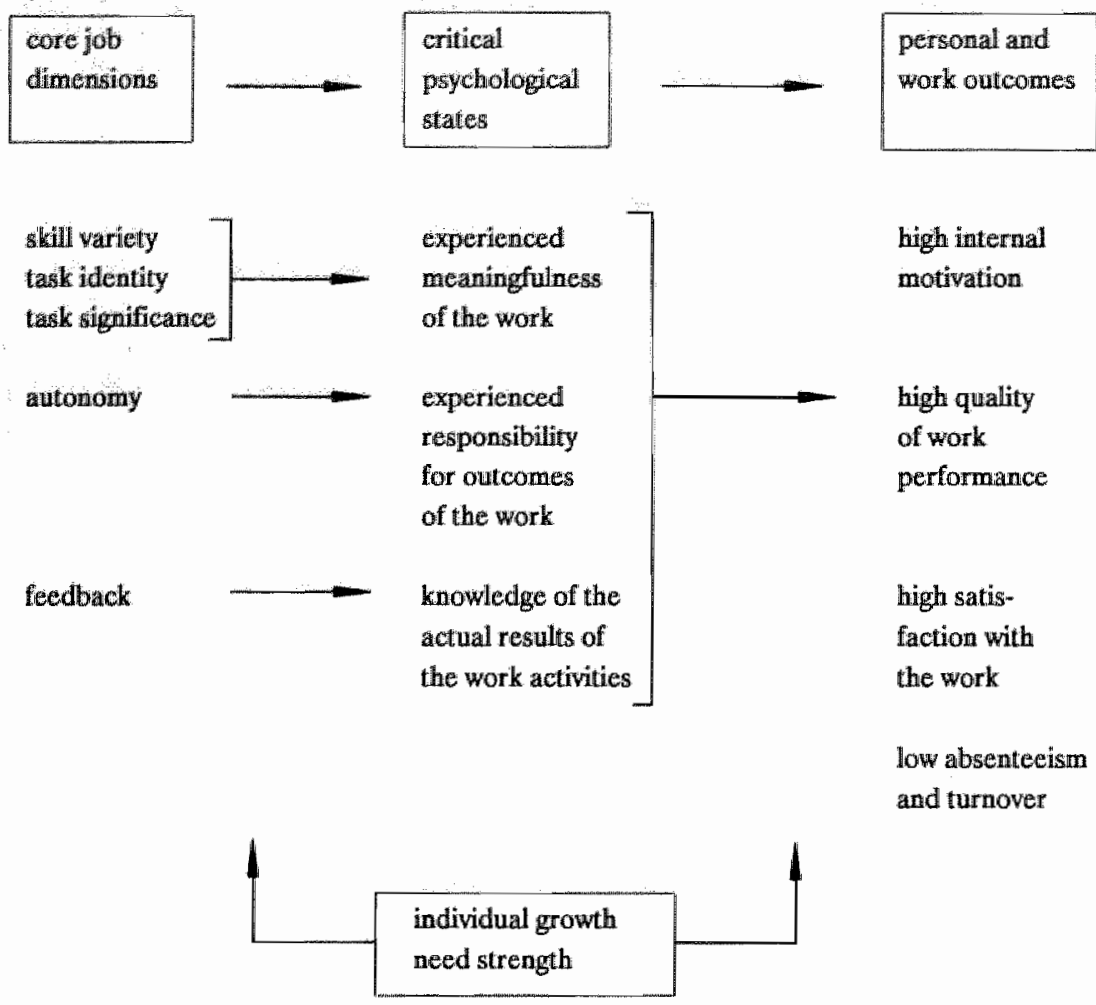

Figuur 3.1. Het "Job Characteristics Model" (ontleend aà Hackman en Oldham, 1975, 1976)

De theorie rond het JCM bestaat uit een aantal veronderstellingen ten aanzien van de relaties tussen de centrale taakkenmerken, de kritische psychologische toestanden en de effecten. De drie psychologische toestanden: ervaren betekenis, ervaren verantwoordelijkheid en kennis van resultaten, die verondersteld worden invloed te hebben op de "effect"-variabelen (motivatie, kwaliteit van het werk, satisfactie, verzuim en verloop) worden op hun beurt voorspeld door de mate waarin bepaalde taakkenmerken aanwezig zijn in het werk. Zo wordt verwacht dat de taakkenmerken: afwisseling, identiteit en belang, verantwoordelijk zijn voor de intermediërende variabele ervaren betekenis, dat autonomie gerelateerd is aan ervaren verantwoordelijkheid en dat feedback van invloed is op kennis van resultaten. Een centrale gedachtengang van het model is dat een individu een positieve gewaarwording ervaart in de mate waarin hij aan de weet komt (kennis van resultaten) dat hij persoonlijk (ervaren verantwoordelijkheid) een goede prestatie heeft geleverd bij het uitvoeren van een taak die hij zinvol vindt (ervaren betekenis). Deze positieve gewaarwording zou fungeren als bekrachtiging ("reinforcement") van het gedrag van het individu en dient als aansporing ("incentive") voor het individu om ook in de toekomst een goede prestatie te leveren (Hackman en Oldham, 1976; Algera, 1981).

De vijf centrale taakkenmerken worden als volgt gecombineerd tot de "Motivating Potential Score" (MPS), die het motiverend vermogen van het werk uitdrukt: 
MPS $=($ afwisseling + identiteit + bellang $) \mathrm{x}$ autonomie $\mathrm{x}$ feedback

Eveneens onderscheidden Hackman en Oldham de twee additionele taakdimensies "dealing with others" en "feedback from agents", die echter in het JCM niet gerelateerd worden aan de reactie-variabelen.

Zowel volgens Turner en Lawrence als volgens Hackman en Lawler kunnen verschillen in persoonskenmerken tussen mensen mede de manier bepalen waarop ze reageren op hun werk. In het JCM wordt er van uitgegaan dat de variabele "groeibehoefte" een modererende functie heeft en wel in die zin dat mensen met een grote behoefte aan persoonlijke groei en ontwikkeling positiever zullen reageren op werk dat hoog scoort op de MPS dan mensen met een lage groeibehoefte. Hackman en Oldham ontwikkelden voor het meten van de verschillende variabelen de "Job Diagnostic Survey (JDS)".

\subsection{De geldigheid van het "Job Characteristics Model"}

Sinds de formulering wan het JCM door Hackman en Oldham hebben zich talloze studies gericht op het weerleggen c.q. bevestigen van eén of meerdere veronderstellingen in het model. Een aantal kritische overzichtsartikelen (Roberts en Glick, 1981; O'Brien, 1982) getuigt van de grote nadruk die binnen de taakontwerpbenadering op het model gelegd is. De geldigheid van het JCM zal in deze paragraaf besproken worden aan de hand van een aantal relevante thema's, te weten de toetsing van de in het model gepostuleerde relaties (3.3.1), de invloed van moderatoren (3.3.2), de dimensionaliteit van het taakdomein (3.3.3) en het objectief versus subjectief meten van taakkenmerken (3.3.4). Een uitgebreide bespreking van de geldigheid is in die zin belangrijk dat het in de nabeschouwing (zie 3.4) zal uitmonden in enkele aanbevelingen aangaande een eventuele herformulering van het model.

\subsubsection{De toetsing van de in het "Job Characteristics Model" gepostuleerde relaties}

TOETSING VAN HET GEHELE MODEL

Slechts weinig onderzoeken hebben het volledige model met z'n specifieke patroon van veronderstelde relaties tussen de (klassen van) variabelen bestudeerd. De onderzoeken van Hackman en Oldham (1976), Wall e.a. (1978) en Algera (1981) vormen hierop uitzonderingen. Hackman en Oldham (1976) hebben met behulp van correlaties en multiple regressie-analyses de causale relaties die het model postuleert plausibel trachten te maken. De resultaten van deze analyses vormden volgens de onderzoekers een sterke onderbouwing van de validiteit van het model. Terecht wordt hierbij door verschillende auteurs (Algera, 1981) de kritische kanttekening gemaakt dat met behulp van de door Hackman en Oldham toegepaste methoden geen causale verbanden bewezen kunnen worden. Bovendien bestaan er meer stringente methoden die het mogelijk maken het model in éen keer te toetsen, in plaats van verschillende deelanalyses uit te voeren.

Zo maakten Wall e.a. (1978) gebruik van de padanalyse, waarbij ze het JCM vergeleken met een alternatief model dat in die zin van het JCM verschilde dat er rechtstreekse relaties tussen 
taakkenmerken en reactie-variabelen woorspeld werden. De resultaten lieten zien dat het alternatief model een significant grotere portie variantie verklaarde dan het JCM, hetgeen vooral twijfels uitriep over de plaats van de "kritische psychologische toestanden".

Een ander voorbeeld van simultane toetsing van het JCM is het onderzoek van Algera (1981). Hij deed dit met behulp van het programma LisRel (zie Jöreskog en Sörbom, 1978) waarmee nagegaan kan worden in hoeverre een bepaald model verenigbaar is met de empirische gegevens (de "fit"). Bij deze toetsing bleek dat de "fit" tussen het model en de empirische gegevens slecht was. Dit gold zowel woor de analyses verricht op basis van de gegevens van Hackman en Oldham (1976), van Wall e.e: (1978) als van Algera zelf. Op basis van de correlatiepatronen en suggesties in de literatuur (Wall e.a., 1978) kwamen Algera e.a. (1986) tot een herformulering van het model, waarin de voornaamste modificatie daaruit bestond dat de variabelen "interne motivatie" en "betrokkenilheid" tot de intermediërende "kritische psychologische toestanden" werden gerekend en "psychische klachten" als aftankelijke variabelen werden beschouwd in een vierde stadium na arbeidstevredenheid. Bovendien gebruikten Algera e.a. een ander set taakkenmerken, namelijk "significance", "complexity", "object variety", "interaction", "autonomy" en "motor variety". Wederom bleek de "fit" onvoldoende te zijn. Belangrijk te vermelden is dat het toevoegen van psychische klachten aan de groep afhankelijke wariabelen plaatsvond in navolging van Wall e.a. (1978), die terecht aangaven dat psychische klachten eveneens voorspelbaar kunnen zijn uit de taakkenmerken. Deze relatie is echter tot nu toe binnen de taakkenmerkenbenadering en specifiek in het JCM van Hackman en Oldham verwaarloosd gebleven.

De meeste onderzoeken die opgezet zijn vanuit de taakkenmerkenbenadering volgens het JCM hebben, in tegenstelling tot de hiervoor besproken studies, de aandacht gericht op de relatie tussen taakkenmerken en reacties enerzijds en de mogelijke invloed van moderatoren, voornamelijk "Growth Need Strength", op deze relatie anderzijds. De toetsing van de intermediërende plaats van de kritische psychologische toestanden en de daarmee samenhangende invloed van GNS op twéé plaatsen in het model (zie figuur 3.1) heeft slechts op beperkte schaal plaatsgevonden.

Gezien de omvangrijkheid van de studies die vooral na Hackman en Lawler (1971) en Hackman en Oldham $(1975,1976)$ verricht zijn, is het niet doenlijk in het kader van deze studie een overzicht te verschaffen van de resultaten van al deze onderzoeken. We zullen ons dan ook voornamelijk beperken tot de bespreking van enkele belangrijke krítische overzichtsartikelen en meta-analyses, die getuigen van een gedegen inzicht in de voor handen zijnde problematiek.

\section{TOETSING VAN DE RELATIE TUSSEN TAAKKENMERKEN EN REACTIES}

Loher e.a. (1985) maakten gebruik van zogenaamde meta-analyses om de aard van de relatie tussen de vijf taakkenmerken van Hackman en Oldham en de reactie-variabele arbeidstevredenheid te bepalen. Deze relatie wordt vastgesteld door te achterbalen in welke mate de variantie tussen correlatiecoëfficiënten afkomstig van de 28 in de meta-analyses betrokken onderzoeken toegeschreven kan worden aan zaken als "sampling error" en "measurement unreliability". Loher e.a. kwamen tot de conclusie dat er slechts een matige relatie bestaat tussen taakkenmerken en arbeidstevredenheid (varierend van .32 tot .46). Bovendien bleek een substantieel deel van de variantie verklaard te worden door andere factoren, bijvoorbeeld de invloed van moderatoren zoals GNS.

Stone (1986) geeft in zijn artikel een zogenaamde "kwantitatief georiënteerd overzicht" van 27 veldonderzoeken (correlationeel of experimenteel) en 7 laboratoriumonderzoeken, waarin de 
resultaten van deze studies met betrekking tot de gevonderi relaties tussen "job scope" en arbeidstevredenheid (algemene tevredenheid en tevredenheid met het werk) en tussen "job scope" en taakuitvoering worden geëvalueerd. Onder "job scope" verstaat de auteur de mate waarin een taak verrijkt is, dat wil zeggen gekenmerkt wordt door de taakkenmerken die in het JCM worden beschreven. Het begrip "job scope" kan derhalve inhoudelijk vergeleken worden met de "Motivating Potential Score" van Hackman en Oldham. Ook de benaming "complexiteit" wordt vaak gehanteerd wanneer men het over de mate van verrijking van de taak heeft. Met behulp van de kwantitatieve analyse van Stone (1986) werd een schatting verkregen van een gecombineerde, gewogen (volgens de omvang van de onderzoekspopulaties) correlatie-coëfficiënt van de predictor-criterium variabelen in kwestie, gebaseerd op de gevonden coëfficiënten in de bestudeerde onderzoeken. Deze gewogen correlatiecoęfficiënten zijn telkens berekend voor de veldonderzoeken en laboratoriumonderzoeken afzonderlijk. De resultaten gaven aan dat de correlaties tussen "job scope" en satisfactie redelijk tot hoog zijn (variërend van .53 tot .93 ), zowel voor de groep veldonderzoeken alls voor de groep laboratoriumstudies. De relaties tussen "job scope" en taakuitwoering zijn echter matig.

Een punt van kritiek op de analyse van Stone is ons inziens dat de toegepaste kwantitatieve analyse niet corrigeert voor "sampling error" en "measurement unreliability", hetgeen bij Loher e.a. (1985) en bij de hierna te bespreken studie van Fried en Ferris (1987) wel het geval is.

Een veel uitgebreidere meta-analyse dan die van Loher e.a. (1985) en Stone (1986) werd vrij recent verricht door Fried en Ferris (1987), waarin 76 studies betrokken werden. De resultaten van de meta-analyse met betrekking tot de relatie taakkenmerken - reactievariabelen lieten zien dat de taakkenmerken "feedback", "autonomie" en "gevarieerdheid" de sterkste relatie hebben met respectievelijk "algemene tevredenheid", "tevredenheid met groeimogelijkheden" en "interne werkmotivatie". Een andere bevinding van Fried en Ferris is dat de taakkenmerken minder sterke, alhoewel significante, verbanden bleken te hebben met de gedragsmatige reacties: taakuitvoering en ziekteverzuim dan met de psychische variabelen zoals tevredenheid (zie ook Pierce en Dunham, 1976).

\section{TOETSING VAN DE INVLOED VAN "GROWTH NEED STRENGTH"}

De invloed van GNS is eveneens in talloze onderzoeken tot onderwerp van studie genomen. Zo kwam uit de meta-analyse van Loher e.a. (1985) naar voren dat de variabele GNS inderdaad een rol speelt als moderator in die zin dat de relatie tussen taakkenmerken en tevredenheid voor werknemers met een grote groeibehoefte sterker was dan voor werknemers met een kleine groeibehoefte. Bij het bepalen van de tevredenheid van werknemers met een lage GNS bleken bovendien andere factoren een belangrijke rol te spelen. Loher e.a. veronderstellen dat deze andere factoren uit situationele kenmerken bestaan (bijvoorbeeld ondersteuning van de werkgroep en/of het management bij het uitvoeren van "verrijkte" taken).

De invloed van de moderator GNS werd ook door Fried en Ferris (1987) in hun meta-analyse behandeld. Uit deze analyses kwam naar voren dat GNS slechts een modererende invloed heeft op de relatie tussen MPS en taakuitvoering; het verband tussen MPS en taakuitvoering bleek sterker te zijn voor mensen met een hoge "Growth Need Strength" dan voor mensen met een lage GNS. Dit matige resultaat met betrekking tot de werking van GNS als moderator wordt ook gesignaleerd door Roberts en Glick (1981) en Graen e.a. (1986). Deze laatsten geven in hun artikel een kritische terugblik op de resultaten van 26 onderzoeken die de invloed van GNS op de relatie taakkenmerken - reactievariabelen (motivatie, satisfactie, taakuitvoering) hebben bestudeerd. Graen e.a. kwamen tot de conclusie dat vaak geen moderator-effecten van GNS 
gevonden worden. De resultaten van die studies die wel een dergelijk effect aantonen, zijn inconsistent. De resultaten van de meta-analyses van Spector (1985) waren positiever, in die zin dat er wel degelijk ondersteuning voor de veronderstelde werking van GNS gevonden wordt, wooral ten aanzien van de variabele: satisfactie. In de analyses van Spector waren de resultaten van 20 onderzoeken betrokken, waarvan een groot aantal ook in de terugblik van Graen e.a. (1986) is gebruikt.

Slechts enkele studies hebben de invloed van GNS op beide door Hackman en Oldham (1976) woorspelde schakels in het model behandeld. Hackman en Oldham zelf meenden met behulp van subgroepanalyses voldoende onderbouwing te vinden voor de invloed van GNS op de schakels respectievelijk tussen taakkenmerken en psychologische toestanden en tussen psychologische toestanden en reactie-variabelen. Terecht wordt door Algera (1981) erop gewezen dat Hackman en Oldham twee subgroepen creëerden die slechts uit de bovenste en onderste $25 \%$ van de scoreverdeling op de variabele GNS bestaan, hetgeen tot een overschatting van het effect kan leiden.

Arnold en House (1980) vonden in hun onderzoek enige ondersteuning voor de invloed van GNS op de relaties tussen taakkenmerken en psychologische toestanden doch geen ondersteuning voor de invloed van GNS op de relatie tussen psychologische toestanden en reactie-variabelen.

\section{TOETSING VAN DE ROL VAN DE MEDIËRENDE VARIABELEN}

Een laatste vraagstelling die enkel in het overzicht van Fried en Ferris (1987) behandeld wordt, is de mediêrende rol van de kritische psychologische toestanden. Slechts in enkele studies is deze vraag nader onderzocht (bijvoorbeeld Hackman en Oldham, 1976; Wall e.a., 1978; Arnold en House, 1980). Het JCM suggereert dat 1) de correlaties tussen specifieke taakkenmerken en bepaalde psychologische toestanden hoger zullen zijn dan de correlaties tussen taakkenmerken en niet-gespecificeerde psychologische toestanden en dat 2 ) de correlaties tussen psychologische toestanden en de reactie-variabelen beduidend hoger zullen zijn dan de correlaties tussen de taakkenmerken en deze reactie-variabelen.

Ten aanzien van de eerste veronderstelling konden Fried en Ferris slechts een zwakke ondersteuning voor de theorie van het JCM verschaffen. Het bleek namelijk dat bepaalde taakkenmerken eveneens belangrijke relaties onderhouden met door het model niet-gespecificeerde psychologische toestanden en visa versa.

Wat betreft de tweede assumptie van het JCM gaven de resultaten aan dat de verbanden tussen de psychologische toestanden en de reactie-variabelen inderdaad sterker zijn dan de verbanden tussen de taakkenmerken en de reactie-variabelen. Wellicht met de uitzondering van de reactie-variabele "taakuitwoering" waarvoor beduidend sterkere correlaties met de taakkenmerken werden aangetroffen dan met de psychologische toestanden.

Bij onderzoek van hun herformulering van het JCM lieten Algera e.a. (1986) de "kritische psychologische toestanden" als intermediërende groep variabelen weg zij het met handhaving van de reactie-variabelen: "satisfactie" en "psychische klachten", in een respectievelijk tweede en derde stadium. De resultaten van de analyses konden het model in deze vorm echter niet onderbouwen. 
- Weinig onderzoeken hebben alle in het "Job Characteristics Model" veronderstelde relaties onderzocht. De meeste onderzoeken richten zich op de relatie tussen talkkenmerken en reactie-variabelen en/of de mogelijke invloed van moderatoren, met name van GNS.

- De mediërende rol van de "kritische psychologische toestanden" is twijfelachtig, hetgeen ertoe geleid heeft, aldus Wall en Martin (1987), dat in vele studies ófwel de psychologische toestanden weggelaten worden (Orpen, 1979) ofwel als afhankelijke variabelen behandeld worden (Kiggundu, 1983).

- Voor de relatie tussen taakkenmerken en reactie-variabelen wordt bij herhaling voldoende ondersteuning gevonden in redelijk tot hoge correlaties. Een matige samenhang wordt gevonden tussen taakkenmerken en de gedragsmatige reacties: taakuitvoering en ziekteverzuim. Een mogelijke verklaring ten aanzien van de weinig positieve resultaten betreffende taakuitvoering is volgens Stone (1986) dat taakuitvoering niet beïnvloed wordt door taakkenmerken maar door contextuele factoren zoals beloningssystemen en normen en waarden van de eigen werkgroep. De minder sterke correlaties tussen taakkenmerken en ziekteverzuim zouden verklaard kunnen worden door het feit dat de analyses aangaande deze variabele veelal verricht zijn op individueel niveau. Op dit probleem wordt nader ingegaan in hoofdstuk 5.

- De resultaten met betrekking tot de modererende werking van GNS zijn matig. Op de invloed. van andere moderatoren wordt in de volgende paragraaf nader ingegaan.

\subsubsection{De invloed van moderatoren}

Na een terugblik op relevante literatuur op het gebied van taakontwerp kwam Hulin in 1975 tot de conclusie dat er behoefte is aan onderzoek naar de bijdrage van individuele verschillen. aan de manier waarop mensen reageren op hun werk(situatie). In 1976 kwamen Pierce en Dunham tot de bevinding: "clearly some workers respond more favorably to expanded task design than do others". Bovendien vermelden ze dat er voldoende aanwijzingen waren dat niet-taak gebonden omgevingsfactoren van invloed zijn op de relatie tussen taakkenmerken enerzijds en reacties van taakuitvoerders anderzijds. Evenals Hulin wezen Pierce en Dunham op de noodzaak van vervolgonderzoek om deze factoren duidelijk af te bakenen en in te passen in een theoretisch model. Op dit moment is het aantal onderzoeken dat gezocht heeft naar moderatoren die van invloed zouden kunnen zijn op de relatie tussen taakkenmerken en reacties van werknemers tamelijk uitgebreid. Het merendeel van deze studies heeft zich geconcentreerd op de invloed van GNS, welke reeds uitgebreid in de vorige paragraaf aan de orde is geweest. Daarnaast is aandacht besteed aan andere individuele moderatoren zoals: protestantse arbeidsmoraal (Stone, 1976; O'Reilly en Caldwell, 1979), stad/platteland (Wanous, 1974), "locus of control" (Kimmons en Greenhaus, 1976; Knoop, 1981), diensttijd (Katz, 1978a, 1978b; Kemp en Cook, 1983) en tevredenheid met taakextrinsieke aspecten zoals salaris, leiding, collega's (Oldham, 1976; Oldham e.a., 1976; Katerberg e.a., 1979).

Slechts enkele studies hebben zich bezig gehouden met organisationele en situationele moderatoren zoals: organisatie-klimaat (Ferris en Gilmore, 1984) en technologie (Brass, 1985). Hulin en Blood (1968) gaven als eersten een overzicht van de onderzoeken op het terrein van de moderatoren met als conclusie dat deze literatuur overstelpt is met methodologische en analytische problemen. $\mathrm{Na}$ hen gaf White in 1978 een overzicht van 29 onderzoeken in zake 
potentięle individuele moderatorvariabelen van psychische, sociaal-psychologische en demografische aard met alls conclusies:

1. Vaak worden geen moderator-effecten gevonden.

2. De effecten wani aantoonbare moderatoren zijn matig en inconsistent.

3. De aanwezigheid van de effecten van vele moderatoren zou herleidbaar zijn op nauwkeurig gedefinieerde begrippen en specifieke onderzoekspopulaties en situaties.

4. Bijna alle onderzoeken waren "cross-sectioneel", met alle kans op verwarring van kenmerken van taakuitvoerders en kenmerken van taken vandien.

5. De meeste onderzoeken vergeleken reacties van werknemers op actuele werksituaties. Dit beperkt de mogelijkheid om tot generalisaties te komen over de manier waarop werschillende werknemers zullen reageren op potentiële veranderingen in het werk.

Op grond van deze vrij negatieve bevindingen kwam White tot de uitspraak dat verder onderzoek wellicht niet tot betere resultaten zal leiden betreffende de invloed van moderatoren, en het derhalve aangewezen is met dergelijk onderzoek te stoppen.

O'Connor e.a. kwamen in 1980 met alternatieve verklaringen voor de door White (1978) gevonden resultaten. In de door White aangehaalde studies fungeert volgens $O^{\prime}$ Connor $e^{2} a_{\text {. }}$ als algemeen aanvaarde hypothese dat reacties van takuitvoerders op objectieve takkkenmerken variëren als een functie van individuele verschillen. Bij het toetsen van deze hypothese zijn bij de meeste onderzoeken echter de objectieve taakkenmerken vervangen door subjectieve beschrijvingen van de taken door de taakuitvoerders. Verscheidene auteurs merken op dat bij subjectieve taakpercepties de kans bestaat dat objectieve taakkenmerken en individuele verschillen worden verward (Schwab en Cummings, 1976; White, 1978). Juist omdat de meeste onderzoeken naar moderatoren uit zijn gegaan van zulke perceptieve taakmetingen, waarbij de taakuitvoerders gevraagd werd zowel zichzelf als hun werk te beschrijven, is het niet verwonderlijk dat White weinig steun vond voor het modererend effect van individuele verschillen. Anderzijds bestaan er onderzoeken (Robey, 1974; O'Reilly, 1977) die suggereren dat gebruikmaking van objectieve metingen de mogelijkheid vergroot om significante effecten te vinden van moderatoren op individueel niveau. In paragraaf 3.3.4 zal echter blijken dat er de nodige steun wordt gevonden voor de veronderstelling dat subjectieve taakpercepties voldoende overeenstemmen met objectieve taakkenmerken.

Een andere mogelijke verklaring die O'Connor e.a. (1980) aandragen voor White's negatieve moderator-bevindingen, is dat de meeste onderzoeken zijn uitgevoerd binnen eén bepaalde werkplek. Dit vermindert de mogelijkheid significante persoon-situatie interacties te achterhalen, omdat 1) organisaties meestal de werknemers selecteren op hun individuele eigenschappen en 2) personen met dezelfde eigenschappen terecht komen op soortgelijke werkplekken. Onderzoek naar moderatoren moet dan ook volgens O'Connor e.a. verricht worden over verschillende werkplekken. Een geheel andere oorzaak is volgens O'Connor e.a. gelegen in de statistische analyse-methode waarmee de invloed van eventuele moderatoren in de meeste studies werd onderzocht, middels namelijk indeling in groepen die hoog of laag scoren op de betreffende moderator-variabele door splitsing bij de mediaan. Op deze manier wordt de "statistical power" om de nulhypothese te verwerpen aangetast met name in geval van kleine onderzoekspopulaties.

O'Connor e.a. komen tot de conclusie dat het niet vinden van significante en consistente moderator-effecten van individuele verschillen eerder te wijten is aan de onderzoeksopzet en gehanteerde meetinstrumenten dan aan foutieve hypothesen; onderzoek op dit gebied moet zeker voortgezet worden. 
In overeenstemming met de opvatting van diverse auteurs kunnen we concluderen dat in dit stadium van onderzoek op het gebied van taakontwerp het verkeerd zou zijn de aandacht voor de werking van individuele verschillen tussen mensen te laten varen.

Wellicht zou daarmee waardevolle informatie over de invloed van aspecten van werk op taakuitvoerders verloren gaan. Het verdient de aanbeveling de moderatoren duidelijk af te bakenen en in te passen in een theoretische kader (Pierce en Dunham, 1976). In de toekomst zou weleens kunnen blijken dat de werking van de moderatoren inderdaad afhankelijk is van specifieke onderzoekspopulaties en -situaties, hetgeen White (1978) veronderstelde. Het voortijdig afstoten van de moderatorfunctie zou dan al te voorbarig blijken te zijn.

\subsubsection{De dimensionaliteit van het taakdomein}

Een belangrijk aandachtspunt binnen de taakkenmerkenbenadering is de vraag welke taakkenmerken gerelateerd zijn aan de reacties van werknemers, zoals arbeidstewredenheid, motivatie, ziekteverzuim en taakuitwoering. In paragraaf 3.2 zijn reeds de te onderscheiden taakkenmerken van respectievelijk Turner en Lawrence (1965), Hackman en Lawler (1971) en Hackman en Oldham (1975) aan de orde gesteld. Daarnaast ontwikkelden Sims e.a. (1976) het meetinstrument de "Job Characteristics Inventory (JCI)", dat dezelfde taakdimensies als die van Hackman en Lawler (1971) in kaart tracht te brengen, waarbij echter een uitbreiding van het aantal items heeft plaats gevonden.

Op het moment blijkt de "Job Diagnostic Survey" (zie 3.2) van Hackman en Oldham (1975) het meest gebruikt te worden ter bepaling van taakdimensies (Pierce en Dunham, 1978; Kulik e.a., 1988). Deze populariteit is eerder het gevolg van het bestaan van de taakkenmerken-theorie van Hackman en Oldham dan van de psychometrische kwaliteiten die de JDS zou bezitten (Idaszak en Drasgow, 1987).

Onderzoeken die de dimensionaliteit van de JDS hebben bestudeerd komen tot inconsistente factorstructuren. Zo konden de onderzoeken van Abdel-Halim (1978) en Katz (1978a) de vijf-factorenstructuur van de JDS bevestigen. De studies van Dunham (1976), Dunham e.a. (1977), Green e.a. (1979), Pokorney e.a. (1980) en Fried en Ferris (1986) kwamen echter tot de conclusie dat een én, twee, drie of vier-factor oplossing beter geschikt is om de dimensionaliteit van de JDS te beschrijven.

Dunham e.a. (1977), die voor 20 diverse beroepsgroepen verschillende factoroplossingen van de JDS vonden, concludeerden hieruit dat de resultaten van de factoranalyses mogelijk afhankelijk zijn van specifieke onderzoekspopulaties.

Meer recentelijk kwamen Harvey e.a. (1985) tot een alternatieve verklaring van de inconsistente resultaten betreffende de JDS, namelijk dat de negatief geformuleerde items de oorzaak van alle tegenstrijdigheden vormen. In navolging van Harvey e.a. introduceerden Idaszak en Drasgow (1987) een herziening van de JDS, waarin de betreffende negatief geformuleerde items herschreven werden tot positief geformuleerde items. De vervolgens verrichte factoranalyse bevestigde inderdaad het bestaan van de vijf a priori dimensies. Kulik e.a. (1988) vergeleken hierop de oude met de herziene versie van de JDS en kwamen tot de conclusie dat de herziene JDS inderdaad een verbetering oplevert. Echter de resultaten van vervolgens verrichte analyses gaven aan dat de herziene items de bruikbaarheid van de IDS in het 
voorspellen van reactie-variabelen (satisfactie, motivatie, produktiviteit) niet konden verbeteren (Kulik e.a., 1988).

Gegeven de bevindingen van Kulik e.a. resteert de wragg, eerder geopperd door Roberts en Glick (1981), O'Brien (1982) en Wall en Martin (1987), of de vijf taakdimensies van Hackman en Oldham het gehele taakdomein onvatten. Wellicht zijn er andere kenmerken van de taak die reacties van werknemers beïnvloeden. Verschillende onderzoekers die zich in hun studies niet uitsluitend of geheel niet richten op de onderhavige vijf dimensies wijzen op taakkenmerken die bepalend zouden kunnen zijn woor de werkbeleving van taakuitvoerders zoals "skillutilization" (Caplan e.a., 1975; O'Brien, 1982; Arsenault en Dolan, 1983), "challenge" (Katerberg e.a., 1979; Abush en Burkhead, 1984; Leppănen, 1985), "learning opportunities" (Katerberg e.a., 1979), "job participation" (Caplan e.a., 1975; Arsenault en Dolan, 1983), "social contacts" (Caplan e.a., 1975; Leppänen, 1985) en "work pressure" (Billings en Moos, 1982; "The work Environment Scale"). Campion en Thayer (1985) presenteren in hun artikel een meetschaal bestaande uit 16 taakdimensies, waaronder de vijf taakkenmerken van Hackman en Oldham. Deze 16 taakdimensies zijn afkomstig van diverse auteurs die het zogenaamd "motivationele" taakontwerp als theoretisch uitgangspunt hebben gekozen. De somscore van de taakdimensies bleek positief te correleren met tevredenheid, motivatie, taakuitvoering en negatief met ziekteverzuim en gezondheidsklachten. Ook Algera (1981) kwam op grond van een literatuurstudie tot een uitbreiding van het aantal taakkenmerken tot 24 , welke hij relateerde aan verscheidene reactie-variabelen.

Behalve vragen met betrekking tot de uitgebreidheid van het taakdomein kan men eveneens overwegen of niet ook niet-taakgebonden factoren betrokken moeten worden bij de voorspelling van reacties zoals tevredenheid. Er bestaan verschillende meetinstrumenten voor werkkenmerken ("work characteristics") die naast de meting van taakkenmerken ook aandacht besteden aan de operationalisatie van organisatiefactoren zoals leiderschap (de "Perceived Work Environment", Newman, 1977; zie ILO/WHO Committee, 1984). Wellicht zou een uitbreiding van de taakkenmerken met éen of meerdere niet-taakgebonden factoren de voorspelling van bijvoorbeeld satisfactie kunnen verbeteren. Deze veronderstelling past geheel in het theoretisch kader van waaruit Wallis (1987) reacties van verpleegkundigen op het werk tracht te verklaren. Naast de "job characteristics" onderscheidt Wallis namelijk ook nog "organizational factors" en "environmental factors" als belangrijke predictoren van reacties. Wallis laat echter na deze factoren nader in te vullen.

\section{CONCLUSIES}

We kunnen stellen dat op dit moment het meetinstrument de "Job Diagnostic Survey" van Hackman en Oldham (1975) het meest gebruikt wordt om taakkenmerken in kaart te brengen. De vijf centrale taakdimensies van het "Job Characteristics Model" blijken echter niet te beschikken over een duidelijke reproduceerbare factorstructuur. Een mogelijke verklaring hiervoor is volgens Dunham e.a. (1977) dat de structuur van de JDS varieert tussen verschillende onderzoekspopulaties. Een andere oorzaak wordt gezocht in de negatief geformuleerde items (Harvey e.a., 1985). Echter alhoewel een herformulering van deze items een verbetering van de structuur oplevert, geeft de herziene JDS geen betere voorspelling van de reactie-variabelen (Kulik e.a., 1988). Een uitbreiding van de taakkenmerken (Algera, 1981) en inpassing van niet-taakgebonden factoren in het taakkenmerkenmodel zou wellicht een betere voorspelling van de reactie-variabelen kunnen opleveren. 


\subsubsection{Het objectief versus subjectief meten van taakkenmerken}

De taakkenmerken-theorie van Hackman en Oldharn $(1975,1976)$ stelt dat de gepercipieerde taak een functie is van objectieve taakelementen en dat dergelijke percepties wan talken gerelateerd zijn aan reacties van taakuitwoerders. Wanneer men het "Job Characteristics Model" wan toepassing wil doen zijn voor werkstructurering, is het van essentieel bellang dat er sprake is van een hoge overeenstemming tussen gepercipieerde (subjectieve) en objectieve taakkenmerken (Shaw, 1980; O'Brien, 1982). Dit uiterst belangrijke thema wordt besproken door Roberts en Glick (1981). Zij stellen dat binnen de takkkenmerkenbenadering geen duidelijk onderscheid gemaakt wordt tussen "within-person"-relaties, "person-situation"-relaties en "situational"-relaties. Wanneer men uitgaat van "within-person"--relaties, vindt er een subjectieve beoordeling plaats van de taakdimensies, waarbij zowel de taakdimensies als de reacties op deze dimensies beoordeeld worden door de taakuitvoerder zelf. Wanneer men echter uitgaat van de "person-situation"-relatie, dienen taken objectief en onafhankelijk van (de perceptie van) taakuitvoerders beoordeeld te worden. Dit kan gebeuren door ofwel beoordelingen van buitenstaanders (observatoren, leidinggevenden) te gebruiken, of wel door de taakkenmerken in kaart te brengen met behulp van onafhankelijke structurele metingen (zie Algera, 1989), zoals bijvoorbeeld de "Position Analysis Questionnaire (PAQ)" van MoCormick e.a. (1976; zie ILO/WHO Committee, 1984). Op het moment is het meest gebruik gemaakt van een "within-person"-model, waarbij men impliciet uitgaat van de veronderstelling dat men objectieve taken meet zonder dit expliciet te stellen (Pierce en Dunham, 1976; Roberts en Glick, 1982; Taber e.a., 1985). Dit gebeurt in navolging van Hackman en Lawler (1971) en Hackman en Oldham (1975) die uitgaan van het gebruik van gepercipieerde taakkenmerken. De argumentatie hiervoor is dat het niet in eerste instantie de objectieve werkelijkheid is die de reacties van taakuitvoerders bepaalt, maar dat de reactie van het individu bepaald wordt door de perceptie die het individu heeft van die objectieve werkelijkheid.

De laatste tijd wordt dan ook steeds meer kritiek geleverd op de manier waarop de traditionele taakkenmerkenbenadering taakdimensies in beeld tracht te brengen. Bepaalde auteurs pleiten sterk voor het meten van objectieve taakkenmerken (Schwab en Cummings, 1976; Aldag e.a., 1981). Het argument hiervoor is dat bij het veranderen van taken de objectieve taakkenmerken veranderd worden en niet de perceptie daarvan. Echter het vaststellen van de objectieve kenmerken zoals bijvoorbeeld "work variety" is een moeilijke aangelegenheid. Voor een uitgebreide behandeling van deze problematiek wordt verwezen naar Algera (1981).

Een ander herhaaldelijk geuit kritiekpunt is het volgende (onder andere Roberts en Glick, 1981). Wanneer men zowel de taakdimensies als de reacties laat beoordelen door de taakuitvoerder zelf en men dit doet met behulp van dezelfde vragenlijsten, zou men de kans op "common method variance" tussen onafhankelijke en afhankelijke variabelen vergroten, waardoor de relatie tussen de perceptie van de taak en de reacties overtrokken wordt. Hieraan ten grondslag ligt het mechanisme van de cognitieve consistentie dat de respondenten belet inconsistent te zijn in hun antwoordpatroon (Salancik en Pfeffer, 1977).

Als reactie op de uitgangspunten van het JCM is een alternatieve benadering van werkstructurering, de "Social Information Processing (SIP)"-benadering, tot stand gekomen, die zijn grondslag vindt in het werk van Salancik en Pfeffer (1977). De grote nadruk op gepercipieerde taakkenmerken in de literatuur heeft de aanzet gevormd voor de groeiende belangstelling voor deze benadering (Wall en Martin, 1987). Onderzoeken die vanuit deze theorie zijn opgezet gaan ervan uit dat subjectieve taakkenmerken en reacties van takuitvoerders niet alleen beinvloed worden door objectieve taakkenmerken, maar ook door informatie vanuit de sociale 
omgeving. Bijvoorbeeld wanneer een werknemer voortdurend van zijn collega's te horen krijgt dat zij het werk als een uitdaging ervaren en tevreden zijn met hun werk, zal deze informatie van inwloed zijn op de perceptie die hij heeft van zijn werk (meer of minder uitdagend), evenals op de reactie die hij vertoont (meer of minder tevreden). Voor een uitgebreide behandeling van de benadering van de "Sockal Information Processing" wordt verwezen naar bijwoorbeeld Thomas en Griffin (1983) en Glick e.a. (1986).

Vrij recent behandelden Fried en Ferris (1987) het gebruik van subjectieve beoordelingen van taakkenmerken door taakuitvoerders versus "objectieve" beoordelingen met behulp van de volgende twee vraagstellingen:

1) Bestaat er een samenhang tussen subjectieve en "objectieve" beoordelingen van taakkenmerken

2) Bestaat er een overeenkomst tussen enerzijds de relaties tussen "objectieve" taakkenmerken en reacties en anderzijds de relaties tussen subjectieve taakkenmerken en reacties.

Deze twee vraagstellingen zijn in tegenstelling tot de eerder aangehaalde meta-analyses van Fried en Ferris (zie 3.3.1) behandeld in een beschrijvende terugblik op de resultaten van relevante studies.

Ten aanzien van de eerste vraag blijkt uit verscheidene laboratoriumexperimenten (O'Reilly en Caldwell, 1979; Weiss en Shaw, 1979) en veldexperimenten (Orpen, 1979; Griffin, 1983) dat objectieve veranderingen in de taak invloed hebben op de perceptie van taakkenmerken in de richting van de verandering.

Bovendien bleek uit een vijftiental onderzoeken (onder andere Hackman en Oldham, 1975; Griffin, 1981; Algera, 1983) dat er een redelijke samenhang bestaat tussen de beoordelingen van taakkenmerken door taakuitvoerders en door buitenstaanders (leidinggevenden, onderzoekers). De resultaten van het organisatie-vergelijkend onderzoek van Nijhuis e.a. (1985) sluiten hierbij aan. In deze studie vergeleken Nijhuis e.a. twee manieren van dataverzameling namelijk de institutionele en vragenlijstmethode. Bij de eerste methode wordt informatie over kenmerken van de organisatie verkregen bij én of meerdere informanten, die doorgaans in de top van de organisatie zitten. Met behulp van de vragenlijst-methode daarentegen verzamelt men de gegevens bij een steekproef van personeelsleden. De resultaten van het onderzoek gaven aan dat beide methoden, voorzover identiek geoperationaliseerd, in redelijke mate convergeren. Wat betreft de tweede vraagstelling toonden de onderzoeken van Oldham e.a. (1976), Stone en Porter (1978), Kiggundu (1980) en Algera (1983, zie ook Algera, 1981) gelijkenis aan in de samenhangen van taakkenmerken beoordeeld door taakuitvoerders en taakkenmerken beoordeeld door buitenstaanders met de reactie-variabelen. Brief en Aldag (1978) echter konden deze bevindingen niet bevestigen. Een andere bevestiging van deze vraagstelling vormen volgens Fried en Ferris de resultaten van de onderzoeken van Umstot e.a. (1976), Orpen (1979) en Ganster (1979). Deze experimentele studies tonen aan dat zowel objectief gemanipuleerde taken als gepercipieerde taakkenmerken invloed hebben op reacties van werknemers. Omdat echter de gepercipieerde taakdimensies telkens meer variantie gemeenschappelijk blijken te hebben met de reactie-variabelen dan de manipulatie van taken blijft het effect van "method variance" niet geheel uitgesloten.

Dit laatste stemt overeen met de bevinding van Glick e.a. (1986) dat taakkenmerken en reactie-variabelen samenhangen vertonen die onafhankelijk zijn van methode-effecten, ook al kan "common method variance"' de omvang van de relaties beïnvloeden. De resultaten van het onderzoek van Jenkins e.a. (1983) daarentegen duiden erop dat taakkenmerken en reacties aan elkaar gerelateerd zijn volledig onafhankelijk van "common methode variance". 
In owereenstemming met Fried en Ferris (1987) kunnen we ten aanzien van het gebruik van beoordelingen door taakuitvoerders concluderen, dat de problemen die mogelijk met deze wijze van dataverzameling samenhangen minder serieus zijn dan oorspronkelijk werd aangenomen.

\section{CONCLUSIES}

De vraag of men gebruik moet maken van objectieve dan wel subjectieve taakkenmerken heeft veel aandacht gekregen in de literatuur. De meeste onderzoeken binnen de taakkenmerkenbenadering zijn uitgegaan van gepercipieerde taakkenmerken ("within-person"-model) in tegenstelling tot de meer objectieve vaststelling van taakkenmerken met behulp van beoordelingen van buitenstaanders dan wel onafhankelijke structurele metingen ("person-situation"model). Door gepercipieerde taakdimensies te relateren aan reactie-variabelen zoals tevredenheid en motivatie zou men de kans op "common method variance" vergroten. Echter de zeer gedegen behandeling van deze problematiek door Fried en Ferris (1987) en de bevindingen van Jenkins e.a. (1983) en Glick e.a. (1986) geven steun aan de veronderstelling dat taakkenmerken en reacties van werknemers samenhangen vertonen die onafhankelijk zijn van "common method variance", allhoewel niet geheel kan worden uitgesloten dat "method variance" de omvang van deze samenhangen mogelijk beïnvloedt.

\subsection{Nabeschouwing}

In dit hoofdstuk is uitgebreid aandacht besteed aan het "Job Characteristics Model" van Hackman en Oldham $(1975,1976)$. Er is een overzicht gegeven van de ontwikkelingen op het gebied van de taakkenmerkenbenadering van werkstructurering aan de hand van enkele relevante thema's. Een bespreking van de geldigheid van het JCM brengt enige nog niet opgeloste knelpunten aan het licht. Echter de vrij krasse uitspraak van onder andere Roberts en Glick (1981) dat er weinig vooruitgang zou zijn geboekt sinds de oorspronkelijke herformulering van het model lijkt voorbarig, getuige de positieve bevindingen van andere auteurs (Fried en Ferris, 1987). Uit talloze onderzoeken met verschillende opzet (correlationeel, experimenteel, longitudinaal) komt naar voren dat taakkenmerken samenhangen met reactievariabelen zoals arbeidstevredenheid. Echter de conclusies van de voorafgaande paragrafen geven aan dat het JCM in z'n huidige formulering met z'n specifieke set van variabelen en veronderstelde relaties weinig steun vindt, zodat een onvoorwaardelijke aanbeveling van het model niet terecht is. Alvorens een toepassing van het JCM in een verpleegkundige onderzoekssituatie plaatsvindt, lijkt een herformulering van het model aangewezen.

In een dergelijk herformulering zou aandacht besteed moeten worden aan de volgende knelpunten die zich op dit moment binnen de taakkenmerken-theorie van Hackman en Oldham voordoen:

1a.In een eventuele herformulering lijkt het gerechtvaardigd geen mediërende variabelen in het model op te nemen; variabelen zoals de "kritische psychologische toestanden" van Hackman en Oldham zouden als afhankelijke variabelen beschouwd moeten worden.

$1 \mathrm{~b}$.Bovendien zou een toevoeging van "psychische klachten" aan de groep afhankelijke variabelen een tegemoetkoming zijn aan de verwaarlozing van deze variabelen die binnen de taakkenmerkenbenadering tot nu toe heeft plaatsgevonden (zie ook Wall e.a., 1978; Algera, 1981, 1986). 
2a.Ondanks de vrij negatieve bevindingen aangaande de invloed van moderatoren, zouden dergelijke variabelen in het model opgenomen moeten worden. Aangezien het JCM nog niet toegepast is bij een verpleegkundige populatie, zou met het afstoten wan de moderatorfunctie belangrijke informatie verloren kunnen gaan.

$2 b$,Echter een beperking tot de irvloed wan de uit het JCM afgeleide GNS lijkt voorbarig, daar voor een verpleegkundige onderzoeksgroep ook andere moderatoren in aanmerking kunnen komen (zie hoofdstuk 2).

3a. Voorts lijkt een uitbreiding van het JCM ten aanzien van de taakkenmerken aangewezen wat betreft taakdimensies die kenmerkend zijn voor de werksituatie van de verpleging.

3b.Bovendien zouden niet-taak gebonden variabelen in het model opgenomen moeten worden ter verbetering van de voorspelling van de reactie-variabelen (zie ook Wallis, 1987).

4. Ten aanzien van het subjectief versus objectief meten lijkt de keuze gerechtvaardigd voor subjectieve beoordelingen van taakkenmerken door de verpleegkundigen zelf, indien althans tevens onderzocht wordt of er voldoende convergentie bestaat met "objectieve" beoordelingen door buitenstaanders (bijvoorbeeld leidinggevenden). 


\section{ONDERZOEKSMODEL EN -METHODEN}

\subsection{Inleiding}

De bevindingen in het voorafgaande hoofdstuk leidden tot de conclusie dat het taakkenmerkenmodel van Hackman en Oldham $(1975,1976)$ ) een geschikt uitgangspunt kan vormen voor de concrete invulling van het theoretisch kader van deze studie (zie figuur 1.1). Tevens bleek dat een aantal wijzigingen de bruikbaarheid van het model kunnen bevorderen. Onze herformulering van het taakkenmerkenmodel tot een toepasbaar onderzoeksmodel voor de verpleging bestaat uit de toevoeging van nieuwe variabelen en een wijziging in de specifieke set van veronderstelde relaties. De keuze van de nieuwe variabelen is enerzijds gebaseerd op theoretische overwegingen en anderzijds op de specifieke kenmerken van de verpleegkundige werksituatie.

In dit hoofdstuk zal allereerst het onderzoeksmodel van de huidige studie gepresenteerd worden (4.2). Vervolgens vindt een beschrijving plaats van de planning en uitvoering van het onderzoek (4.3) en van de onderzoekspopulatie (4.4). Voorts zullen de verschillende groepen. variabelen afzonderlijk worden toegelicht, terwijl nader zal worden ingegaan op de operationalisatie (4.5). Daarna komen achtereenvolgens aan de orde de reductie van het aantal variabelen (4.6), de formulering van de onderzoeksvraagstellingen (4.7), de toegepaste statistische analyses (4.8) en de aggregatieniveaus waarop de verwerking heeft plaatsgevonden (4.9).

\subsection{Het onderzoeksmodel}

Het onderzoeksmodel van deze studie wordt gepresenteerd in figuur 4.1.

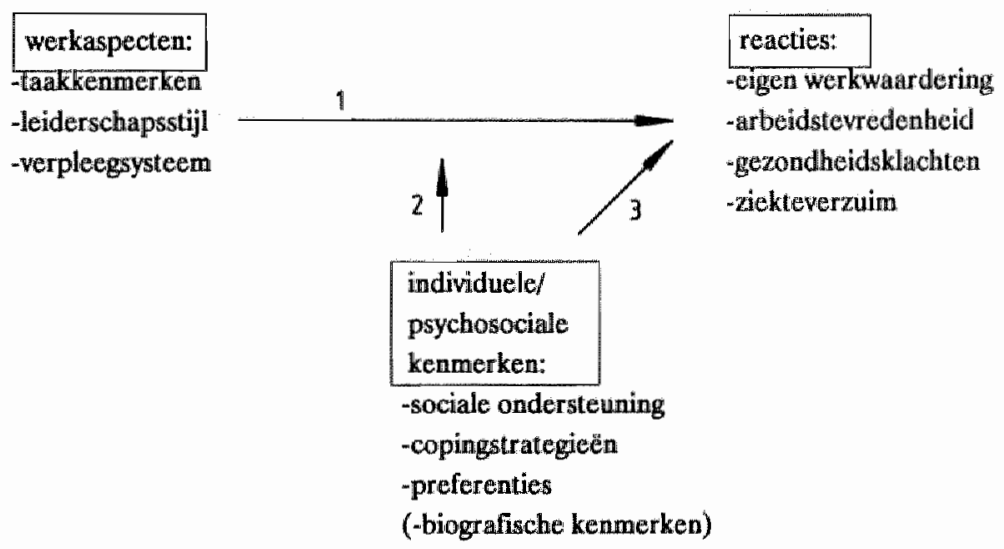

Figuur 4.1. Het onderzoeksmodel van deze studie 
In tegenstelling tot het JCM wan Hackman en Oldham $(1975,1976)$ is in ons onderzoeksmodel de categorie intermediêrende variabelen ("experienced meaningfullness", "experienced responsibility", "knowledge of results") niet als zodanig opgenomen. Deze kritische psychologische toestanden ressorteren in ons model onder de noemer eigen werkwaardering als afhankelijke variabelen, samen met tevredenheid, ziekteverzuim en de in navolging van Wall e.a. (1978) en Algera (1981) nieuw toegevoegde variabele "gezondheidsklachten".

Een tweede belangrijke verandering ten aanzien van het JCM bestaat uit het opnemen van twee organisatiekenmerken, te weten de leiderschapsstijl van het afdelingshoofd en het gehanteerde werpleegsysteem op de afdeling. Naast de groep taakkenmerken zullen beide variabelen in het model fungeren als predictoren van reacties van verpleegkundigen op hun werk (pijl 1).

Een laatste wijziging bestaat uit een uitbreiding van de groep "derde variabelen". De invloed van de individuele kenmerken: preferenties, gehanteerde copingstrategieën en biografische kenmerken, en van het psychosociale kenmerk: sociale ondersteuning, zal nader bestudeerd worden. Naast bestudering van de bufferfunctie van deze variabelen in het model (pijl 2), zal ook onderzocht worden of een direct effect op de reactie-variabelen beter of eveneens van toepassing is (pijl 3).

\subsection{Planning en uitvoering van het onderzoek}

Menigeen zal een overzicht van alle activiteiten die hebben plaatsgevonden in het totale kader van het onderzoek wellicht overbodig achten, aangezien in een wetenschappelijke verslaglegging vooral ingegaan moet worden op zaken die wetenswaardig zijn in verband met een eventuele replicatie van het onderzoek. Echter een specifieke opgave van alle onderzoeksactiviteiten geeft een goed inzicht in al het werk dat verricht moet worden alvorens een onderzoek als afgerond beschouwd kan worden. Ook die informatie is uiteraard interessant voor eventuele "replicatieonderzoekers". Tabel 4.1 geeft een chronologische opsomming van de activiteiten ter voorbereilding van het onderzoek. Tabel 4.2 laat een overzicht zien van de onderzoekspopulaties die betrokken waren bij de vragenlijstanalyse van de verschillende schalen in het vooronderzoek. Tabel 4.3 tenslotte geeft een samenvatting van die activiteiten die in het kader van het eigenlijke hoofdonderzoek geplaatst moeten worden.

Tabel 4.1. Activiteiten in het kader van de voorbereidingsfase

preferenties, eigen werkwaardering, gezondheidsklachten en satisfactie):

- op zes verpleegafdelingen in een psychiatrische instelling $(\mathrm{n}=65,90 \%$ respons)

(Boumans, 1985)

- op een verpleegafdeling in een academisch ziekenhuis (Stoffels, 1985)

- afname vragenlijst op een verpleegafdeling in hetzelfde academisch ziekenthwis

(Landeweerd, 1985) (totaal aantal respondenten in het academisch ziekenhuis was 35,

100 or respons). 
Opstellen van de definitieve onderzoelksopzet en aanpassing en voltooing van de vragenlijist.

Vooronderzoek op acht verpleegafdelingen van een Acadenuisch ziekenihuis (m $=69,47 \%$ respons).

Verwerking van de data en terugkoppeling van de resultaten van de acht werpleegafdelingen van het Academisch ziekenhuis in de vorm wan een rapport (Boumans, 1987a).

Contactlegging met een Categoraal ziekenhuis in verband met eventuele deelname aanhet vooronderzoek.

Voorbereiding vooronderzoek van de vragenlijst in het Categoraal ziekenhuis.

Vooronderzoek op vier verpleegafdelingen van het Categoraal ziekenhwis, verwerking en verslaglegging ( $n=103,94 \%$ respons) (Schoonbeek, 1987)

Vooronderzoek in een verpleeghuis op 11 verpleegafdelingen $(\mathrm{n}=197,97 \%$ respons) (ten Vergert, 1987)

Vragenlijstanalyse: factor-en betrouwbaarheidsanalyses op basis van de gegevens van de vooronderzoeken (zie tabel 4.2 voor een volledig overzicht van de onderzoekspopulaties die betrokken waren bij het vragenlijstonderzoek van de verschillende schalen). febr. 86 - matart 86

april "86- juni "86

juli 86 - aug: 86

sept. 86

oct. 86 - nov. 86

dec. $86-$ juni 87

febr. 87 - juni 87

febr. "87 - aprill' 87

Tabel 4.2. Overzicht onderzoekspopulaties betrokken bij de vragenlijstanalyse (factor- en betrouwbaarheidsanalyses *) van de verschillende schalen in het vooronderzoek

Instelling Aantal resp. Aantal afd. Vragerlijstonderzoek

\begin{tabular}{|c|c|c|c|c|c|}
\hline Psychiatrisch ziekenhuis & 65 & 5 & & & Schaal D,F, G,I \\
\hline Academisch ziekenhuis & 35 & 2 & & & $(\mathrm{n}=272)^{* *}$ \\
\hline Academisch ziekenhuis & 69 & 8 & Schaal A & Schaal & \\
\hline Categoriaal ziekenthuis & 103 & 4 & $(\mathrm{n}=369)^{* * *}$ & $\mathrm{~B}_{\mathrm{s}} \mathrm{C}, \mathrm{E}_{\mathrm{j}} \mathrm{H}$ & \\
\hline Verpleeghuis & 197 & 11 & & $(n=172)^{*}$ & \\
\hline
\end{tabular}

Schaal $A=$ Taakkenmerken; Schaal B = Verpleegsysteem; Schaal C $=$ Leiderschapsstijl; Schaal D $=$ Eigen werkwaardering; Schaal $\mathbb{E}=$ Satisfactie**; Schaal $F=$ Gezonidheidsklacluten $(2 x)$; Schaal $G=$ Copingstrategieën; Schaal $\mathbf{H}=$ Sociale ondersteuning; Schaal I $=$ Preferenties.

* Voor de schaal "werpleegsysteem" zijn frequentieverdelingen berekend.

** De verschillende samenstelling wan de onderzoekspopulaties betrokken bij de rragenlijstonderzoeken van de afzonderlijke schalen heeft te maken met tussentijdse revisies van diverse schalen. Bovendien kwanen de data van het verpleeghuis binnen op het moment dat het laatste vragenlijst-onderzoek bijna was afgesloten, zodat deze gegevens slechts voor de analyse van schaal A gebruikt zijn.

*** Voor een bespreking van de schalen wordt verwezen naar paragraaf 4.5 . 
Tabel 43. Adiviteiten in het tadet wan luet hoofdonderroek

Activiteit

Feriode

Stekproftreklking en schrifteliyke benadering van de ziekenhwizen

jan. 87

Eerste oriênterende gesprekken in de 16 ziekenhuizen en het maken wan definitieve febr. $87-$ april 87 afspraken voor de afname van de vragenlijsten.

Aframe van de wragenlijsten in de 16 zekenthuizen op de 36 verpleegafdelingenmei 87 - febr. "88 $(\mathrm{n}=709,91 \%$ regpons) inclusief voxtbereiding van de dataverwerking.

Toezenden van de vragenlijst aan het "verpleegkundig management". jan. 88

Dataverwerking met behulp van het SPSSX-pakket. maart ' 88 - aug. ' 88

\subsection{Beschrijving van de onderzoekspopulatie}

Aan het hoofdonderzoek hebben 16 ziekenhuizen verspreid over Nederland deelgenomen. Er is gezorgd voor een evenredige spreiding om eventuele regionale invloeden tegen te gaan. De ziekenhuizen zijn verkregen door Nederland te verdelen in vier zones (zie tabel 4.4) en vervolgens in elke zone aselect vier ziekenhuizen te kiezen. Een voorwaarde voor deelname aan het onderzoek was dat het ziekenhuis in bezit moest zijn van een $\mathrm{ICU}$, een $\mathrm{CCU}$ of een gecombineerde IC/CCU. Dit vanwege de voorgenomen vergelijking tussen ICU's en niet-ICU's. Naast deze steekproef werd op dezelfde wijze een schaduwsteekproef uitgevoerd, zonder teruglegging van een reeds in de eerste steekproef getrokken ziekenhuis. Op deze wijze kon een ziekenhuis uit de eerste steekproef dat weigerde deel te nemen aan het onderzoek direct verwangen worden. In totaal hebben vier zlekenhuizen wit de eerste steekproeftrekking hun deelname aan het onderzoek geweigerd. Redenen hiervoor waren bijvoorbeeld een onstabiele situatie in het ziekenluuis en op de verpleegafdelingen in verband met een groot aantal vacatures of "enquête-moeheid" in verband met het grote aantal reeds verrichte onderzoeken.

Tabel 4.4. Indeling in vier zones

\begin{tabular}{ll}
\hline Zone & Provincies \\
\hline Noord & Groningen, Friesland, Drenthe \\
Oost & Overijssel, Gelderland, Flewoland \\
West & Utrecht, Noord-Holland, Zuid-Holland \\
Zuid & Zeeland, Noord-Brabant, Limburg
\end{tabular}


Hoewel de steekproeftrekking is uitgegaan van alle Nederlandse ziekenhuizen (academisch, categoraal, algemeen) bleken uiteindelijk alle 16 ziekenhuizen uit onze onderzoeksgroep algemene ziekenhuizen te zijn.

Tabel 4.5 geeft een overzicht van de grootte's van de ziekenhuizen (uitgedrukt in het aantal erkende bedden; NZI, 1985).

Tabel 4.5. De grootte van de ziekenhinizen

Grootte wan thet ziekenhuis Aanal zickenhuizen

\begin{tabular}{lc}
\hline$<150$ bedden & - \\
$150-300$ bedden & 4 \\
$300-500$ bedden & 5 \\
$>\quad 500$ bedden & 7 \\
\hline
\end{tabular}

De 16 deelnemende ziekenhuizen zijn in eerste instantie benaderd met een brief (zie bijlage 1) gericht aan de directie met een korte toelichting op de inhoud en opzet van het onderzoek en het verzoek om een eerste oriënterend gesprek. Vervolgens is in alle 16 ziekenhuizen een eerste gesprek gevoerd met leden van de directie en/of hoofd Verplegingsdienst en/of coördinerende hoofd(en). Hierin werd door de onderzoeker een uitgebreide toelichting gegeven op het onderzoek. Verder werd gevraagd om een bevestiging van deelname van het ziekenhuis aan het onderzoek. Bovendien werd in de meeste gesprekken een eerste aanzet gegeven tot het selecteren van de deelnemende afdelingen en werd een periode aangegeven waarin eventueel de afname van de schriftelijke enquêtes, waarmee de benodigde gegevens verzameld zouden worden (zie 4.5), zou kunnen plaatsvinden. In elk ziekenhuis werden eén (of twee) ICU's (ICU, CCU; ICU/CCU) en én algemene verpleegafdeling (interne en/of chirurgische afdelingen) geselecteerd. Vervolgens werden de verpleegafdelingen door het hoofd Verplegingsdienst of het betreffende coördinerende hoofd en een begeleidende brief van de onderzoeker op de hoogte gebracht van het onderzoek. Daarna werd in overleg met de afdelingshoofden een exacte planning van de afname van de enquêtes (data, tijden, deelnemerslijst) opgesteld. Deze planning werd schriftelijk vastgelegd en doorgegeven aan de onderzoeker. De afname van de enquêtes vond plaats in zo groot mogelijke groepen verpleegkundigen onder werktijd en in aanwezigheid van de onderzoeker. De invultijd voor de vragenlijsten was ongeveer een uur. De enquêtes zijn ingevuld door de afdelingshoofden, de sub/waarnemende hoofden, gediplomeerd- en leerling verpleegkundigen en HBOV-stagiaires. Op algemene verpleegafdelingen werden ziekenverzorgers(sters) uitgesloten van deelname. Op Intensive Care afdelingen werden die verpleegkundigen uitgesloten die niet in het bezit waren wan een IC-diploma en ook niet met deze opleiding bezig waren op het moment van het onderzoek. De reden voor deze selectie was dat bij deze groepen gewoonlijk sprake is van een ander takenpakket en taakomschrijving dan bij de rest van de verpleegkundige staf.

In totaal hebben 709 verpleegkundigen aan het onderzoek meegedaan (91\% respons). De verdeling van de respondenten over de verschillende typen afdelingen is weergegeven in tabel 4.6.

$\mathrm{Na}$ aftrek van die verpleegkundigen, die korter dan drie maanden werkzaam zijn op de verpleegafdeling, bleef een aantal. over van 630 . Verwacht kon namelijk worden dat men op 
een werpleegafdeling enige tijd werkzaam moet zijn om zich een goed beeid te kunnen vormen van de "normale" gang wan zakern.

Tabell 4.6. Verdeling respondenten over de iypen afdelingen

\begin{tabular}{|c|c|c|c|c|}
\hline type afdeling & Hartal offi. & aanial resp. & $\begin{array}{l}\text { aantal resp. } \\
<3 \text { maanden }\end{array}$ & $\begin{array}{l}\text { definitieve } \\
\text { steekproef }\end{array}$ \\
\hline alginterne & 7 & 139 & 21 & 118 \\
\hline algchirurgie & 9 & 206 & 36 & 170 \\
\hline ICU & 9 & 160 & 8 & 152 \\
\hline $\mathrm{CCU}$ & 4 & 62. & 5 & 57 \\
\hline \multirow[t]{2}{*}{$1 \mathrm{C} / \mathrm{CCU}$} & 7 & 142 & 9 & 133 \\
\hline & $\cdots$ & 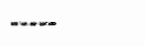 & $\ldots$ & $\ldots$ \\
\hline Totaal & 36 & 709 & 79 & 630 \\
\hline
\end{tabular}

Aan het onderzoek (definitieve steekproef) namen in totaal 168 mannen (26.7\%) en 461 vrouwen ( $73.2 \%$ ) deel (op de variabele geslacht was én missing value). De gemiddelde leeftijd is 30 jaar ( $\mathrm{SD}=6.96)$. De gemiddelde diensttijd in de verpleging is 10.4 jaar $(\mathrm{SD}=6.5)$, in het ziekenhuis 7.6 jaar $(S D=5.25)$ en op de verpleegafdeling 4.3 jaar $(S D=4.42)$.

Voor de beantwoording van vraagstelling 6 (zie 4.7), waarvoor een vergelijking plaatsvindt tussen de beoordelingen van de taakkenmerken door de verpleegkundigen en door het verpleegkundig management, is voor elke verpleegafdeling de schaal "taakkenmerken" (zie 4.5) ingevuld door een of meerdere personen uit het hoger verpleegkundig management van het ziekenhuis. Tot deze groep behoorden het coördinerende hoofd, de assistent hoofd Verplegingsdienst, het hoofd Verplegingsdienst en in sommige gevallen de verpleegkundig directeur c.q. de directeur Patiëntenzorg. Het aantal personen uit het hoger verpleegkundig management dat elke verpleegafdeling beoordeelde op de taakkenmerken was afhankelijk van de hiërarchische structuur van de Verplegingsdienst binnen elk ziekenhuis. In sommige (kleinere) ziekenhuizen ressorteerden de verpleegafdelingen rechtstreeks onder het hoofd Verplegingsdienst (of onder de verpleegkundig directeur). In de meeste andere ziekenhuizen bestonden tussen hoofd Verplegingsdienst en de afdelingen de functies van assistent hoofd Verplegingsdienst en coördinerend hoofd. De vragenlijst, die naast de schaal taakkenmerken eveneens een gedeelte biografische kenmerken bevatte, is in totaal aan 56 personen verstuurd, waarvan 54 de enquête retourneerden ( $96 \%$ respons). Het aantal personen dat de verpleegafdeling beoordeelde op de taakkenmerken varieerde tussen de éen en drie per afdeling. Omdat dit aantal te beperkt was, is bij nader inzien besloten eveneens de afdelingshoofden en sub/waarnemend hoofden te rekenen tot het verpleegkundig management, en daarmee uit te sluiten van alle andere analyses die uitgevoerd zijn voor beantwoording van de vraagstellingen 1-5 ${ }^{1)}$ (zie 4.7). Tabel 4.7 geeft een overzicht van de groep "verpleegkundig management" ingedeeld naar functie. 
Tabel 4.7. Overzicht groep "verpleegkundig management" ingedeeld naar functie

\begin{tabular}{lc}
\hline Functie & Aantal \\
\hline A.fidelingshoofd & 35 \\
sub/wnd hoofd & 34 \\
hoofd V.D. & 28 \\
coördinerend hoofd & 13 \\
anders & 13 \\
& -123 \\
\hline
\end{tabular}

\subsection{Toelichting op de variabelen}

\subsubsection{Inleiding}

In deze paragraaf zullen de verschillende concepten uit het onderzoeksmodel (zie figuur 4.1) en de operationalisaties worden toegelicht. Meer uitgebreid zal worden ingegaan op die variabelen die in het model van Hackman en Oldham niet voorkomen en in dit onderzoek zijn toegevoegd. Hierbij zal vooral aandacht besteed worden aan de theoretische achtergrond en de onderzoeksresultaten met betrekking tot deze variabelen. Alvorens van start te gaan met de beschrijving van de afzonderlijke variabelen dienen enkele algemene opmerkingen gemaakt te worden aangaande de operationalisatie.

Voor het meten van de verschillende variabelen in het onderzoeksmodel is gebruik gemaakt van vragenlijsten. De totale vragenlijst die de verpleegkundigen werd voorgelegd bestond uit de volgende schalen:

- taakkenmerken

- leiderschapsstijl

- verpleegsysteem

- eigen werkwaardering

- arbeildssatisfactie

- gezondheidsklachten

- ziekteverzuim

- sociale ondersteuning

- copingstrategieẻn

- preferenties

- biografische kenmerken.

Het merendeel van de schalen is gebaseerd op het werk van andere auteurs, al dan niet aangepast aan de speciffeke situatie van de verpleging.

In de eerste opzet van het onderzoek was het de bedoeling de factorstructuur en interne consistentie van de verschillende schalen vast te stellen op basis van de gegevens van een aantal vooronderzoeken (zie tabel 4.1 en 4.2). Dit kon echter niet geheel gerealiseerd worden. Zo bleken de schalen "leiderschapsstijl" en "gezondheidsklachten" goede factorstructuren en 
betrouwbaarheden te bezitten. De resultaten met betrekking tot de structuur van het merendee] van de schalen waren echter niet optimaal. De schalen "taakkenmerken" en "verpleegsysteem" lieten in deze minder bevredigende resultaten zien. De resultaten van het vragenlijstonderzoek met betrekking tot de schalen: arbeidssatisfactie, eigen werkwaardering, copingstrategieën, sociale ondersteuning en preferenties, waren redelijk. Echter ondanks de benoem-baarheid wan de geïdentificeerde factoren en de redelijke proporties verklaarde varianties, bleek dat in deze schalen een aantal a priori inhoudelijk relevante variabelen niet als zelfstandige factoren terug te vinden waren. Op grond wan deze overweging werd besloten de definitieve factorstructuur van alle schalen te bepalen op basis van de gegevens van het hoofdonderzoek. Vervolgens werden op basis van de bevindingen in het vooronderzoek door middel van herformulering, toevoeging dan wel weglating van bepaalde items de nodige veranderingen aangebracht in de lijsten "taakkenmerken", "verpleegsysteem", "satisfactie" en "eigen werkwaardering".

Gezien de goede resultaten in het vooronderzoek bleven de schalen: leiderschapsstijl en gezondheidsklachten, onveranderd. Op basis van bekende goede psychometrische eigenschappen zijn ook de schalen: copingstrategieën, sociale ondersteuning en preferenties, ongewijzigd in het hoofdonderzoek opgenomen (zie respectievelijk Schreurs e.a., 1984; Reiche en Van Dijkhuizen, 1979; Algera, 1987). Het wegvallen in het vooronderzoek van a priori variabelen in de door ons gevonden factorstructuur van deze schalen is wellicht verklaarbaar op grond van het feit dat het vooronderzoek heeft plaatsgevonden bij een beperkte, relatief homogene onderzoekspopulatie. Daar het hoofdonderzoek zou plaatsvinden bij een grotere en meer heterogene groep werd verwacht dat een grotere spreiding betere factoranalytische resultaten zou opleveren.

In deze studie zullen voor de verschillende schalen ${ }^{2)}$ slechts de definitieve factorstructuur en de betrouwbaarheden, zoals die uiteindelijk zijn vastgesteld op basis van de gegevens van het hoofdonderzoek, in het kort worden beschreven. Voor een meer uitgebreide toelichting op de ontwikkeling van de afzonderlijke schalen en de bevindingen ten aanzien van de schalen in vooren hoofdonderzoek wordt verwezen naar respectievelijk Boumans (1986) en Boumans (1989).

\subsubsection{De werkaspecten}

\subsubsection{Taakkenmerken}

Het opnemen van taakkenmerken in ons onderzoeksmodel als predictoren van reacties van verpleegkundigen is een logisch gevolg van het feit dat het model in oorsprong gebaseerd is op de taakkenmerkenbenadering en specifiek op het "Job Characteristics Model" van Hackman en Oldham $\left.\left(1975_{*} 1976\right)^{3}\right)$. In onze studie heeft echter een uitbreiding van de vijf taakkenmerken van Hackman en Oldham plaatsgevonden, waarbij ook aandacht besteed wordt aan taakaspecten die kenmerkend zijn voor de werksituatie van de verpleging. In hoofdstuk 3 is reeds aan de orde gesteld dat twijfels bestaan, of de vijf taakkenmerken van Hackman en Oldham het gehele taakdomein bevatten.

\section{OPERATTONALISATIE}

De items van de schaal "taakkenmerken" die wij gebruiken zijn gebaseerd op het werk van Hackman en Oldham $(1975,1976)$ en Algera (1981). Om een genoemde aansluiting met de verpleegkundige praktijk te realiseren zijn een aantal items hergeformuleerd en toegevoegd. De uiteindelijke schaal die afgenomen werd in het hoofdonderzoek bestaat uit 40 items. De 
respondent is gevraagd op een zeven-puntsschaal de mate van aan- dan wel afwezigheid van de betreffende werkaspecten aan te geven door aankruising van eén van de 7 hokjes op een horizontale as, oplopend in intensiteit van het betreffende aspect.

De door ons verrichte factoranalyse toonde aan dat de 40 items de volgende zes factoren meten (in volgorde van percentage verklaarde variantie met vermelding van Cronbach's alpha tussen haakjes):
1) complexiteit/moeilijkheid ( 0.87$)$
2) feedback/duidelijkheid (0.72)
3) werkdruk (0.51)
4) autonomie $(0.55)$
5) promotie/groei (0.48)
6) verzorgende en begeleidende activiteiten (0.31).

De interne consistenties zijn redelijk tot hoog, behalve wat betreft de laatst genoemde factor "verzorgende en begeleidende activiteiten". De keuze om toch de factor "verzorgende en begeleidende activiteiten" te zien als zelfstandige en volwaardige factor, ondanks de lage interne consistentie, is louter en alleen op een inhoudelijke argument gebaseerd en wel de specifieke relevantie van deze factor in de verpleging.

\subsubsection{Leiderschapsstijl}

In hoofdstuk 2 werd het functioneren van het afdelingshoofd reeds vermeld als mogelijke bron van stress en/of (on)tevredenheid. Het afdelingshoofd neemt op de verpleegafdeling een centrale plaats in. Deze wordt geacht de van hogere hand voorgeschreven beleidsmaatregelen. uit te voeren en als hoofd beslissingen te nemen die van invloed zijn op de organisatie van de patiëntenzorg en de dagelijkse activiteiten wan de overige afdelingsverpleegkundigen (Duxbury e.a., 1984). Bovendien kan het afdelingshoofd een belangrijke rol spelen bij het motiveren en aansporen van de verpleegkundige staf en het initiëren, invoeren en doen welslagen van veranderingsprocessen zoals patiëntgerichte verpleging (AZG, 1986).

De stijl van leidinggeven van het afdelingshoofd is dan ook wellicht mede bepalend voor de arbeidssatisfactie en het ziekteverzuim van de verpleegkundigen (zie 2.5). Onderzoek naar de invloed van de leiderschapsstijl van het afdelingshoofd op de arbeidsbeleving van de verpleegkundigen heeft echter slechts op beperkte schaal plaatsgevonden. Daarentegen is aan deze variabele in andere sectoren zoals bijvoorbeeld de industrie uitgebreid aandacht besteed (Stogdill; 1974). In de betreffende literatuur wordt, evenals in de verpleegkundige studies, onderscheid gemaakt tussen voornamelijk twee dimensies van leiderschapsgedrag, te weten "taakstructurerend" en "sociaal-emotioneel". Daarnaast wordt ook aandacht besteed aan een derde te onderscheiden aspect aan de leiderschapsstijl, te weten productiegericht leiderschap. Voor een beschrijving van deze drie stijlen wordt verwezen naar hoofdstuk twee.

Zwaga (1981) geeft een uitgebreid overzicht van onderzoeken die de samenhang tussen leiderschapsstijl en arbeidstevredenheid hebben bestudeerd (onder andere Szilagi en Sims, 1974; Stinson en Johnson, 1975). Daaruit blijkt dat sociaal-emotioneel leiderschap over het algemeen positief gecorreleerd is met verscheidene dimensies van arbeidssatisfactie, zoals tevredenheid met de leiding, met collega's, met het werk zelf, met promotiemogelijkheden en met salaris. Wat betreft de relatie tussen taakstructurerend leiderschap en verschillende dimensies van tevredenheid komt naar voren dat deze relatie zowel positief, negatief als niet significant kan zijn (Zwaga, 1981). 
Smulders constateerde in 1984 dat er over de samenhang tussen de twee leiderschapsstijlen en verzuim minder bekend is. Uit zijn bestudering van achttien onderzoeken, die sociaal leiderschap niet als zodanig geoperationaliseerd hebben, maar afzonderijke kenmerken van deze stijl zoals luisteren, aandacht woor gevoelens, respect etcetera in relatie brachten met verzuim, kwam. naar voren, dat sociaal leiderschap negatief gecorreleerd is met verzuim (Smulders, 1984). De resultaten aangaande de relatie tussen taakstructurerend leiderschap en verzuim bleken uit een overzicht van veertien onderzoeken tegenstrijdig te zijn (Smulders, 1984). Het merendeel van de gevonden correlaties bleek niet-significant te zijn, terwijl naast enkele negatieve ook positieve werbanden werden aangetroffen.

Over de invloed van beide leiderschapsgedragingen op gezondheidsklachten en dimensies van eigen werkwaardering zoals ervaren betekenis, ervaren verantwoordelijkheid en motivatie is niets of nauwelijks iets bekend.

Vroegere onderzoeken beschouwden sociaal-emotioneel en taakstructurerend leiderschap als twee uiterste polen van én enkele dimensie (Likert, 1961). Latere studies echter leggen de nadruk op de onafhankelijkheid van deze twee stijlen (Philipsen en Cassee, 1965) en onderzoeken de interactie van sociaal en structurerend leiderschapsgedrag als predictoren van reacties van werknemers (Fleisman en Harris, 1962). In paragraaf 2.5 zijn twee onderzoeken aangehaald die de invloed van verschillende combinaties van beide leiderschapsstijlen op arbeidsvoldoening van verpleegkundigen hebben onderzocht. Op grond van het beperkt aantal onderzoeken betreffende dit onderwerp kan men geen eenduidige conclusies baseren. Desalniettemin blijft het effect van verschillende combinaties wan sociaal-emotioneel en takstructurerend leiderschap op reacties van verpleegkundigen op hun werk een interessante vraagstelling.

Ook naar de samenhang tussen leiderschapsstijlen en taakkenmerken is weinig onderzoek verricht. Johns (1978) vond sociaal leiderschap positief gerelateerd aan de taakkenmerken "variety", "identity" en "significance". Taakstructurerend leiderschap bleek met geen van de zes taakkenmerken van Hackman en Oldham $(1975,1976)$ significant gecorreleerd te zijn.

\section{OPERATIONALISATIE}

De schaal die gebruikt is om het begrip leiderschapsstijl te meten is gebaseerd op een door Zwaga (1981) vertaalde versie van de bekende "Leadership Behavior Questionnaire" van Stogdill (1963). De schaal "leiderschapsstijl" bestaat uit 20 items, waarbij de respondent op een vijf-puntsschaal moet aangeven hoe vaak zij/hij een bepaald soort leiderschapsstijl bij het afdelingshoofd waarneemt. Factoranalytisch kon aangetoond worden dat sociaal-emotioneel leiderschap wordt gemeten met 11 items en zogenaamd instrumenteel leiderschap, inclusief aspecten van productiegericht en taakstructurerend leiderschap (zie ook Philipsen, 1965) met 9 items wordt gemeten. De interne consistentie van beide factoren is hoog, namelijk respectievelijk 0.90 en 0.82 .

\subsubsection{Verpleegsysteem}

Verscheidene auteurs geven aan dat de werkorganisatie van grote invloed kan zijn op de manier waarop werknemers c.q. verpleegkundigen hun werk beleven (Van Bergen, 1972; Mercx, 1975a; 1975b; Van Assen en Den Hertog, 1980). Op de meeste verpleegafdlelingen in Nederland werd en wordt nog steeds zogenaamd functioneel verpleegd, hetgeen wil zeggen dat het werk opgedeeld is in kleinere deeltaken die door de hoofdverpleegkundige aan de andere (leerling-) verpleegkundigen worden toegewezen. Deze toegewezen taken moet de verpleegkundige bij 
alle in aanmerking komende patiënten op de afdeling verrichten. Deze Tayloriaanse arbeidsdeling beoogt een optinale gebruikmaking van mankracht en middelen. Geen van de verpleegkundigen kent zodoende echter de patiënt in zijn totaliteit. Alleen de hoofdverpleegkundige heeft de beschikking over alle gegevens en onderhoudt de contacten met de artsen. Steeds meer wint in verpleegkundige kringen de overtuiging veld dat dit in strijd is met het uitgangspunt dat de verpleging probeert aan te nemen, namelijk dat elke patiënt uniek is en dat de patieznt als socio-psycho-somatische eenheid verpleegd en verzorgd moet worden.

Het rapport van Van Bergen (1972) leidt zelfs tot de conclusie dat de traditionele functionele organisatiestructuur van verpleging dysfunctioneel is ten aanziern van de patient en bovendien demotiverend voor de verpleegkundigen: de patiënt ziet per dag veel verschillende verpleeg* kundigen die allen druk bezig zijn met hun "(deel)taken" zonder tijd te hebben voor de vragen en angsten van de individuele patiënt. De verpleegkundige daarentegen heeft meestal dit beroep gekozen om mensen te helpen, hetgeen in deze situatie vaak een desillusie wordt. In het systeem van taaktoewrijzing ontbreekt de gelegenheid om een goede zorgrelatie op te bouwen en komt de continuiteit van de zorg in het gedrang. In een tijd waarin de mondigheid van de patiënt toeneemt, grote groepen MDGO-VP- (v6́r 1985 MBO) en HBO-opgeleiden hun intrede in de verpleging doen en de verpleegkundige beroepsontwikkeling en professionalisering centraal staan wordt de vraag naar organisatorische aanpassingen steeds luider (AZG, 1986).

De laatste jaren is men zich dan ook steeds meer bewust geworden van de problemen die functionele verpleging met zich meebrengt. Vandaar dat men is gaan zoeken naar andere vormen van verpleging. In deze andere vormen ligt de grote nadruk op patiëntgericht verplegen; (groepen) verpleegkundigen krijgen patiënten toegewezen die ze volledig verzorgen en verplegen. Deze toewijzing van patiënten kan plaatsvinden op basis van groepen, teams of units (Nederlandse 4) "Teamverpleging", Themo ${ }^{5}$-verpleging, groepsverpleging) of op basis van individuele verpleegkundigen ("Primary Nursing", Integrerende Verpleegkunde, Individuele Verpleging). De gemeenschappelijke doelstelling in deze nieuwe benaderingswijzen is het bevorderen van de kwaliteit van de verpleegkundige zorgverlening door onder andere de aandacht te vestigen op de integratie van somatische, psychische en sociale zorgaspecten, het vergroten van de betrokkenheid van de patiënt zelf in het zorgverleningsproces, de waarborging van de continuiteit van zorg, en het vergroten van het verantwoordelijkheidsbesef van de verpleegkundigen.

Er vindt een verticale taakverrijking plaats omdat verpleegkundigen betrokken worden in alle fasen van het zorgproces, namelijk de diagnostisering van het verpleegkundig probleem en vervolgens de planning, uitvoering en evaluatie van de verschillende activiteiten.

In hoofdstuk 2 is reeds uit de resultaten van verschillende onderzoeken gebleken dat verpleegsystemen waarin de nadruk ligt op patiëntentoewijzing de arbeidsvoldoening, betrokkenheid en motivatie van verpleegkundigen bevorderen en het verzuim en verloop verminderen (Mercx, 1975b; NZR, 1979; Boekholdt, 1981; Alexander e.a., 1981; Sellick e.a., 1983; AZG, 1986). Over de effecten van de manier van verplegen op gezondheidsklachten en dimensies van eigen werkwaardering zoals ervaren betekenis, kennis van resultaten en ervaren verantwoordelijkheid etcetera is nauwelijks iets bekend.

Wel kan de verwachting uitgesproken worden dat patiëntgericht verplegen gepaard gaat met bepaalde leiderschapsstijlen. Zo bleek uit het onderzoek van Boekholdt (1981) dat met de invoering van groepsverpleging minder instrumenteel leiderschap ervaren werd. Er deed zich echter geen verandering voor in het sociaal-emotioneel leiderschap. Mercx (1975b) daarentegen vermelde dat op de experimentele afdelingen waar groepsverpleging gehanteerd werd 
minder instrumenteel en meer sociaal leiderschap werd toegeschreven aan het afdelingshoofd dan op de controle-afdelingen. In een reeds in hoofdstuk 2 behandeld onderzoek van Higthower (1986) bleken affelingshoofden van "primary nursing" afdelingen meer relatiegericht gedrag te vertonen dan afdelingshoofden van "non-primary" afdelingen.

Naar de relatie tussen verpleegsystemen en taakkenmerken is nauwelijks onderzoek verricht. De enige studie die ons bekend is vormt het afstudeerwerk van Durlinger (1981). Echter vanwege de geringe differentiatie in scores op het Meetinstrument Teamverpleging en op de taakkenmerken van de "Iob Diagnostic Survey" zijn de resultaten vrij beperkt. Er werd slechts ến significant (positief) verband aangetroffen, namelijk tussen de score op enkele teamverplegingselementen uit het cluster "overleg" (bijvoorbeeld werkoverleg, werkplanning, afdelingsbespreking) en de mate waarin men aangeeft van anderen informatie te krijgen over de eigen werkprestaties ("feedback from agents").

\section{OPERATIONALISATIE}

Bij het operationaliseren van de variabele "verpleegsysteem" deden zich twee moeilijkheden voor. Op de eerste plaats bleek er geen vragenlijst voorhanden die als basis kon dienen voor het benodigde meetinstrument in deze. Wel bestaan er schalen ter evaluatie van een bepaald type verpleegsysteem (bijvoorbeeld Themoverpleging, zie Van den Heuvel 1976, zie ook NZR, 1979). Bovendien bestond de verwachting dat er op de verpleegafdelingen in Nederland niet strikt én type verpleegsysteem wordt toegepast. In de praktijk blijkt namelijk meestal sprake te zijn van een mengvorm van verschillende verpleegmodellen. Bij het meetbaar maken van het concept verpleegsysteem zijn we uitgegaan van de volgende vierdeling van de werkorganisatie van Mercx (1975a):

A. functionele verpleging: iedere verplegende verricht bepaalde handelingen bij alle daartoe in aanmerking komende patiënten op de gehele afdeling;

B. partiële functionele verpleging: de afdeling is verdeeld in units en iedere verplegende verricht bepaalde handelingen bij alle daartoe in aanmerking komende patiënten binnen de unit (vergelijkbaar met "Team Nursing" in de Verenigde Staten);

C. partiële individuele verpleging: de afdeling is verdeeld in units en liedere verplegende heeft een aantal patiënten die zij (hij) verpleegt en verzorgt. Een aantal handelingen mag zij, als zij leerling is tenminste, niet zelf verrichten. Deze worden verricht door een andere verplegende van de unit op de afdeling. Een gediplomeerde doet uiteraard alles voor haar patiënten zelf, en helpt de leerlingen in haar unit met die handelingen die deze niet zelfstandig mogen verrichten (vergelijkbaar met Themoverpleging en Teamverpleging in Nederland);

D. individuele verpleging: alle verplegenden (in dit geval allemaal verpleegkundigen) hebben ieder een aantal patiënten die ze integraal verplegen en verzorgen. Daarbij kunnen ze eventueel de hulp van bijvoorbeeld een verpleeghulp krijgen (vergelijkbaar met Integrerende Verpleegkunde en "Primary Nursing").

Voor elke type verpleegsysteem is een zo eenduidig mogelijke omschrijving opgesteld. De respondenten wordt gevraagd op een vijf-puntsschaal de mate van overeenstemming aan te geven van elk van de vier omschreven organisatiemodellen met de organisatie op de eigen afdeling. Bij factoranalyse bleek de schaal unidimensioneel. Van de scores op de vier verpleegsystemen, die te beschouwen zijn als afzonderlijke items, wordt een somscore berekend die de factor "taakgericht (versus patiëntgericht) verplegen" aanduidt. Een hoge somscore op deze factor betekent een hoge mate van taakgericht verplegen en een lage mate van patiëntgericht 
verplegen. Een lage somscore geeft een indicatie voor het tegenovergestelde. De interne consistentie van de factor "taakgericht (versus patiëntgericht) verplegen" is 0.59 .

\subsubsection{De reactie-variabelen}

Zoals we in hoofdstuk 3 hebben kunnen zien, zijn in het "Job Characteristics Model" van Hackman en Oldham $(1975,1976)$ de variabelen arbeidstevredenheid, motivatie, kwaliteit van de taakuitvoering, ziekteverzuim en verloop als reacties (effecten) opgenomen. Conform Hackman en Oldham en hun navolgers hebben we ervoor gekozen in elk geval arbeidssatisfactie en ziekteverzuim in ons onderzoek als indicatoren van een positieve ciq. negatieve werkevaluatie te betrekken. Bovendien hebben we hieraan het samenvattend concept "eigen werkwaardering" toegevoegd, waaronder variabelen ressorteren clie de ervaring van aspecten van het werk in kaart brengen, zoals bijvoorbeeld de drie "kritische psychologische toestanden" en "motivatie" van Hackman en Oldham. De variabele "arbeidstevredenheid" geeft een indicatie voor de mate waarin een persoon zich welbevindt in zijn werk (Thierry en Koopman-Iwema, 1983), terwijl de afzonderlijke tevredenheidsdimensies met verschillende werkaspecten veel concreter aangeven in hoeverre aan bepaalde behoeften wordt voldaan.

In navolging van Wall e.a. (1978) en Algera (1981) is eveneens de tot nu toe binnen de taakkenmerkenbenadering verwaarloosde variabele "gezondheidsklachten" in ons model opgenomen als mogelijke reactie van werpleegkundigen op hun werksituatie. Het gaat hierbij om psychische en psycho-somatische klachten die mensen kunnen ervaren en die als zodanig in de stressliteratur en specifiek in studies naar werkstress als reactie-variabelen worden aangemerkt (Reiche en Van Dijkhuizen, 1979).

De variabele "kwaliteit van de taakuitvoering" wordt in onze studie uitgesloten, aangezien onze belangstelling meer uitgaat naar psychische (bijvoorbeeld satisfactie, mervositeit), psycho-somatische (bijvoorbeeld algemene malaise) en gedragsmatige reacties (bijvoorbeeld ziekteverzuim) van verpleegkundigen dan naar prestatiegerichte dimensies zoals taakuitvoering. Bovendien is de operationalisatie van de variabele "kwaliteit van de taakuitvoering" in de verpleging een lastige aangelegenheid. Evenals bij de operationalisatie van de "kwaliteit van de verpleegkundige zorgverlening" moet men aan de verschillende zorgactiviteiten een waarde-oordeel toekennen. Levert bijvoorbeeld de verpleegkundige die meer aandacht besteedt aan de psychische begeleiding van de patiënt een betere c.q. slechtere zorg dan de verpleegkundige die de patiënt een goede lichamelijke verzorging verleent.

Een bijkomende reden was dat men in de gezondheidszorg van start is gegaan met "functiewaardering". Dit zou er toe kunnen leiden dat vragen met betrekking tot de werkprestaties als bedreigend door de verpleegkundigen ervaren zouden kunnen worden vooral in die ziekenhuizen waar men nog moest starten met functiewaardering ten tijde van het onderzoek, ook al valt de wijze waarop iemand zijn werk verricht buiten het terrein van "functiewaardering" (De Jong en Thierry, 1983). Bovendien zou de anonimiteit van de verpleegkundigen in het gedrang komen indien men op de meest gangbare manier de taakuitwoering achterhaalt, namelijk met behulp van beoordeling van de taakuitvoering door bijvoorbeeld het afdelingshoofd of collega-verpleegkundigen (zie ook Algera, 1981).

De reactie-variabelen worden verwacht niet onafhankelijk van elkaar te zijn. Zo blijkt uit de literatuuroverzichten van zowel Zwaga (1983) als van Rosse en Miller (1984) dat verzuim negatief samenhangt met voornamelijk algemene tevredenheid en tevredenheid met het werk. Tussen verzuim en tevredenheid met de leiding en tevredenheid met de collega"s worden geen 
significante relaties aangetroffen. De bevindingen ten aanzien van de relatie tussen verzuim enerzijds en tevredenheid met salaris en met promotie anderzijds zijn miet eenduidig; er worden zowel negatieve als niet-significante correlaties aangetroffen. Zwaga (1983) zelf echter vond in zijn onderzoek bijwerpleegkundigen uit algemene ziekenhuizen weinig steun voor de samenhang tussen verzuim en verschillende tevredenheidsdimensies. Tenslotte blijkt verzuim bij Algera (1981) nauwelijks en bij Wall e.a. (1978) redelijk samen te hangen met gezondheidsklachten. Verzuim correleert slechts zwak met de kritische psychologische toestanden (Hackman en Oldham, 1976; Wall e.a., 1978; Algera, 1981).

Uit de gegevens van Hackman en Oldham (1976), Wall e.a. (1978) en Algera (1981) komt eveneens naar voren dat er een redelijke samenhang bestaat tussen de kritische psychologische toestanden en verschillende tevredenheidsdimensies, evenals tussen gezondheidsklachten en tevredenheid, en dat er een matige samenhang gevonden wordt tussen gezondheidsklachten en kritische psychologische toestanden. De gegevens met betrekking tot de gezondheidsklachten zijn steeds afkomstig van Wall e.a. en Algera, aangezien Hackman en Oldham deze variabele niet in hun onderzoek betrokken hebben. In de volgende subparagrafen zal voor elke afhankelijke variabele afzonderlijk worden ingegaan op de operationalisatie.

\subsubsection{Eigen werkwaardering}

\section{OPERATIONALISATIE}

Voor het meetbaar maken van de variabele "eigen werkwaardering" is in eerste instantie gebruik gemaakt van de operationalisering van dit begrip door Algera (1981), mede met het oog op mogelijke vergelijking van de data uit de verpleegkundige sector met die uit de industrie. Tevens werd zo aansluiting verkregen met het taakkenmerkenmodel, omdat de schaal van Algera de drie kritische psychologische toestanden inschaalt. De uiteindelijke schaal die in het hoofdonderzoek is afgenomen bestaat uit 26 items, welke uitspraken betreffen over het werk, waarbij de respondent op een vijf-puntsschaal (lopend van "volledig mee eens" tot "volledig mee oneens"), moet aangeven in hoeverre zij/hij het met de uitspraak (on)eens is. Uit onze factoranalyse bleek dat de schaal de volgende zes factoren meet (in volgorde van percentage verklaarde variantie met vermelding van Cronbach's alpha):
1) algemene werkvoldoening (0.81)
2) ervaren belasting ( 0.68$)$
3) ervaren verantwoordelijkheid (0.66)
4) interne werkmotivatie $(0.60)$
5) ervaren betekenis $(0.62)$
6) kennis van resultaten $(0.57)$.

\subsubsection{Satisfactie}

\section{OPERATTONALISATIE}

Om dezelfde redenen als vermeld bij "eigen werkwaardering" werd ook voor het meten van "satisfactie" de operationalisering van Algera (1981) gebruikt. Daar echter enkele items te zeer op de industriële situatie sloegen, leken een aantal herformuleringen noodzakelijk (bijvoorbeeld 
"bedrijf" vervangen door "ziekenhuis"' en "chef" door "afdelingshoofd"). Tevens zijin door middel van de nodige items tevredenheidsdimensies toegevoegd, die in een verpleegkundige setting mogelijk van belang zijn (zie bijvoorbeeld Hinshaw en Atwood, 1984). De uiteindelijke schaal bestaat uit 36 items die betrekking hebben op aspecten binnen het werk ten aanzien waarvan de respondent heeft aan te geven in welke mate zij/hij tevreden is met die aspecten, op een vijf-puntsschaal lopend van "zeer tevreden" tot "zeer ontevreden". De schaal meet de volgende zeven tevredenheidsfactoren:

1) tevredenheid met kwaliteit van zorg (0.86)

2) tevredenheid met het afdelingshoofd $(0.90)$

3) tevredenheid met contacten collega's (0.81)

4) tevredenheid met promotiemogelijkheden $(0.84)$

5) tevredenheid met contacten patiënten $(0.74)$

6) tevredenheid met duidelijkheid (0.64)

7) tevredenheid met groeimogelijkheden $(0.70)$.

\subsubsection{Gezondheidsklachten}

\section{OPERATIONALISATIE}

Als operationalisering van de variabele "gezondheidsklachten" is eveneens in navolging van Algera (1981) gebruik gemaakt van twee schalen die een onderdeel vormen van de V ragenlijst Organisatie Stress (vos) (Reiche en Van Dijkhuizen, 1979). Aan de vos ligt het theoretisch model over de effecten van psychosociale stress op gezondheid en ziekte van Caplan e.a. (1975) ten grondslag.

De eerste schaal heeft betrekking op psychosomatische klachten. De schaal bestaat uit 11 items die de volgende twee factoren meten:

1) algemene malaise (0.57)

2) ervaren hartklachten (0.61).

De eerste factor wordt in de vos "algemene gezondheid" genoemd. Gezien de negatieve formulering van de items is echter gekozen voor een eveneens negatieve benaming "algemene malaise". De items die gebruikt worden om beide factoren in te schalen, beschrijven gezondheidservaringen ten aanzien waarvan de respondent wordt gevraagd op een vier-puntsschaal, lopend van "zeer vaak" tot "nooit", aan te geven hoe vaak zij/hij gedurende de afgelopen maand die ervaringen op het werk heeft gehad.

De tweede schaal betreffende drie soorten psychische klachten bestat uit 15 items die betrekking hebben op gevoelens. Aan de respondent wordt gevratagd aan te geven op een vier-puntsschaal, lopend van erg "vaak" tot "nooit of bijna nooit", hoe vaak zij/hij die gevoelens op het werk ervaart. De drie factoren die met behulp van deze schaal gemeten worden zijn de volgende:

1) gespannenheid/nervositeit $(0.76)$

2) geprikkeldheid (0.85)

3) depressiviteit $(0.72)$. 


\subsubsection{Ziekteverzuim}

\section{OPERATIONALISATHE}

Het vaststellen van de hoogte wan het ziekteverzuim kon op twee manieren gebeuren:

1) Het verkrigen van objectieve verzuimgegevens via de administratie van het ziekenhuis

2) Het verzamelen van persoonlijke verzuimgegevens bij de respondenten zelf met behulp van de vragenlijst.

Aangezien de eerste methode de meest betrouwbare gegevens zou opleveren, bestond de intentie deze vorm van dataverzameling toe te passen. Echter al gauw bleek dat in de bij het onderzoek betrokken ziekenhuizen veelal geen gebruik werd gemaakt van geautomatiseerde databestanden. Hierdoor zouden de ziektekaarten van de verpleegkundigen handmatig op onze vragen onderzocht moeten worden. Bovendien waren in een aantal ziekenhuizen de ziekteverzuimgegevens berekend over de hele sector "patiëntenzorg" (inclusief laboranten en dergelijke), waardoor de specifieke cijfers over de verpleegkundigen niet te achterhalen waren. Noodgedwongen moest gebruik gemaakt worden van methode twee.

Hierbij moest de wraag gesteld worden wat de betrouwbaarheid is van dergelijke zelf gerapporteerde verzuilmgegevens. Uit een vooronderzoek bij 203 ziekenverzorgenden (Ten Vergert, 1987) was gebleken, dat er een hoge correlatie bestond tussen persoonlijke en objectieve verzuimgegevens; voor verzuimduur was deze correlatie 0.87 en voor verzuimfrequentie 0.75 . Aangezien in ons onderzoek sprake is van een onderzoekspopulatie die uit dezelfde arbeidssector afkomstig is als de onderzoeksgroep van Ten Vergert, geven de hoge correlaties die Ten Vergert vond tussen persoonlijke en objectieve verzuimgegevens een indicatie voor de betrouwbaarheid van verzuirngegevens werkregen van de respondent zelf.

In de vragenlijst zijn aan de respondent met betrekking tot verzuim de volgende vragen gesteld"

- "Hoe vaak heeft u zich in de afgelopen 12 maanden ziek gemeld?"

- "Hoeveel dagen (kalenderdagen van ziekmelding tot herstelmelding) bent $u$ in de afgelopen

12 maanden wegens ziekte afwezig geweest?"

Op grond hiervan kunnen drie verzuimmaten vastgesteld worden:

1) de totale duur: het totaal aantal verzuimde dagen in eén jaar;

2) de frequentie: het totaal aantal ziekmeldingen in één jaar;

3) de gemiddelde duur: het totaal aantal verzuimde dagen gedeeld door het totaal aantal ziekmeldingen.

Tussen de maten "verzuimpercentage" en "het totaal aantal verzuimde dagen" bestaat verhoudingsgewijs geen verschil. Wellicht overbodig te vermelden is dat alle berekeningen met ziekteverzuim uitgevoerd zullen worden over die respondenten die minstens én jaar op de afdeling werkzaam waren ten tijde van de afname van de enquête.

\subsubsection{De individuele/psychosociale kenmerken}

\subsubsection{Sociale ondersteuning}

In het kader van het belang van sociale interacties tussen mensen voor bun dagelijks leven heeft het concept sociale ondersteuning zich de laatste jaren ontwikkeld tot een belangrijke psychosociale variabele in gezondheidskundige studies met de veronderstelling dat sociale relaties gezondheid beschermende effecten kunnen hebben. Alhoewel de variabele "sociale ondersteuning vooral gebruikt is in onderzoeken naar de invloed van uiteenlopende levensgebeurtenissen 
zoals werkeloosheid, veroudering en pensionering, zwangerschap etcetera op gezondheidsbeleving en ziekte (Gore, 1978), neemt de belangstelling naar de rol van deze wariabele in de werksituatie ook drastisch toe. Ook in onderzoeken in de verpleegkundige arbeidssituatie wordt in toenemende mate aandacht besteed aan sociale ondersteuning (zie hoofdstuk 2). Studies naar de invloed van sociale ondersteuning in de arbeidssituatie zijn veelal opgezet vanuit onderzoeksmodellen die relaties postuleren tussen bepaalde (werk)stressoren, stressreacties en interveniërende variabelen. Stressoren binnen de werksituatie die in onderzoeken betrokken worden, zijn onder andere rolconflict, rolonduidelijkheid, werkdruk, tijdsdruk, overbelasting, "skill underutilization", toekomstonzekerheid, gebrek aan afwisseling, aan autonomie, aan duidelijkheid en aan complexiteit (Reiche, 1982; Karasek e.a., 1982; Billings en Moos, 1982; Jayarathe en Chess, 1984; Gangster e.a., 1986; Chrisholm e.a., 1986). Een aantal van deze werkstressoren zijn ook terug te vinden bij onze taakkenmerken. Een groot verschil tussen beide groepen variabelen is dat de taakkenmerken in tegenstelling tot de stressoren over het algemeen positief geformuleerd zijn en dus ook verwacht worden positieve invloed uit te oefenen op reacties van werknemers.

Gangster e.a. (1986) merken op dat er tot nu toe slechts een beperkt aantal stressoren in studies naar de invloed van sociale ondersteuning op het werk is meegenomen. Volgens hen bestaan er wellicht nog andere organisationele-en taakkenmerken die gerelateerd zijn aan stressreacties.

Stressreacties die gemeten worden, zijn van fysiologische (bloeddruk, cholesterolgehalte), psychische (tevredenheid, angst, depressie) of gedragsmatige aard (roken, ziekteverzuim) (zie bijvoorbeeld het overzicht van Reiche, 1982).

Een bekend voorbeeld van een onderzoeksmodel is het organisatie-stressmodel van Michigan, ontworpen door Kahn e.a. (1964) en nader uitgewerkt door onder andere Caplan e.a. (1975). In Nederland zijn vanuit de Stressgroep Nijmegen verschillende studies opgezet aan de hand van dit model (Van Dijkhuizen, 1980; Reiche, 1982; Van Bastelaer en Van Beers, 1982; Van den Bergh-Braam, 1984; Marcelissen, 1987).

Alhoewel een ieder zich een voorstelling kan maken van de betekenis van sociale ondersteuning worden in de onderzoeksliteratuur zeer diverse definities gehanteerd (Pinneau, 1975; Cobb, 1976; House, 1981). De gehanteerde operationalisaties hangen vaak sterk samen met de formulering van dergelijke definities. Strikt genomen bestaan er twee soorten metingen van sociale ondersteuning: structurele (de aan- of afwezigheid van relaties binnen een sociaal. netwerk; omvang en samenstelling) en functionele metingen (de mate waarin interpersoonlijke relaties bepaalde hulpbronnen verschaffen).

Volgens Marcelissen (1987) wordt met behulp van de meer structurele instrumenten slechts een randvoorwaarde voor sociale ondersteuning gemeten.

In deze studie is gekozen voor de omschrijving van House (1981) omdat deze nauw aansluit bij onze operationalisatie van sociale ondersteuning (onderdeel van de Vragenlijst Organisatie Stress, Reiche en Van Dijkhuizen, 1979) en verschillende functies van steun omvat die ook in diverse andere definities terug te vinden zijn. House omschrijft sociale ondersteuning als een interpersoonlijke transactie bestaande uit één of meerdere van de volgende subconcepten:

1. emotionele steun (waardering, genegenheid, vertrouwen, bezorgdheid, luisteren)

2. waarderingssteun (bevestiging, feedback, sociale vergelijking)

3. informationele steun (advies, suggesties, aanwijzigingen en informatie verstrekkend)

4. instrumentele steun (het werstrekken van geld, arbeid, tijd, interventies in de omgeving).

De rol die sociale ondersteuning heeft bij de bepaling van uiteindelijke reacties op situaties/gebeurtenissen kan als volgt kort worden weergegeven; sociale steun kan een hoofdeffect hebben 
op de stressreacties of een buffereffect op de relatie tussen stressoren en stressreacties (Jayaratne en Chess, 1984; Marcelissen, 1987). Het effect van sociale steun op stressreacties moge duidelijk zijn; sociale ondersteuning heeft een direct effect op psychische, fysiologische en gedragsmatige reacties van mensen ongeacht de aanwezigheid van stressoren. Volgens Buunk en Janssen (1987) vindt een gerichte toetsing van het direct effect van sociale steun op stressreacties dan ook plaats indien gecontroleerd wordt woor de aanwezigheid van stressbronnen. Van een bufferfunctie is sprake wanneer stressoren voor degenen die in hoge mate ondersteuning van anderen ontvangen/ervaren niet tot negatieve (of minder negatieve) stressreacties zullen leiden.

Alhoewel steeds meer onderzoeken naar de rol van sociale ondersteuning in de werksituatie verricht worden; is dit aantal vooralsnog te beperkt om vergaande conclusies te trekken met name aangaande de bufferfunctie. Vandaar dat bij de hieropvolgende bespreking van belangrijke onderzoeksbevindingen ook enkele studies aangehaald zullen worden die niet binnen de specifieke werksetting hebben plaatsgevonden.

Uit verschillende studies komt naar voren dat sociale ondersteuning negatief samenhangt met verscheildene stressreacties (zie het overzicht van Reiche, 1982; Jayaratne en Chess, 1984; Gangster e.a., 1986; Chrisholm e.a., 1986). Met betrekking tot de bufferwerking van sociale ondersteuning zijn de bevindingen echter inconsistent. Verscheidene onderzoeken bevestigen een modererend effect (Gore, 1978; LaRocco e.a., 1980; Reiche, 1982; Winnubst e.a., 1982; Karasek e.a., 1982). Deze modererende rol van sociale steun blijkt echter in grote mate selectief zowel wat betreft de bron van steun (de leidinggevende, de collega's, het thuisfront) als wat de reactie-variabelen betreft (satisfactie, gezondheidsklachten) (Chrisholm e.a., 1986; Gangster e.a., 1986). Diverse andere studies geven daarentegen geen steun aan de bufferwerking van sociale steun (Jayaratne en Chess, 1984; Gangster e.a., 1986). Weer andere onderzoeken rapporteren negatieve buffereffecten in die zin dat sociale ondersteuning de negatieve effecten van stressoren op stressreacties zou vergroten (Abdel-Halim, 1982, Winnubst e.a., 1982; Kaufman en Beehr, 1986).

Met betrekking tot het vinden van een hoofd-of buffereffect concluderen Cohen en Wills (1985) dat vooral dan aanwijzingen voor hoofdeffecten worden gevonden indien als maat voor sociale ondersteuning de integratie in een sociaal netwerk wordt gebruikt. Buffereffecten daarentegen worden voornamelijk aangetroffen in studies die de waargenomen beschikbaarheid van interpersoonlijke hulpbronnen als maat hanteren.

Op grond van voorafgaande bevindingen kan niet eenduidig geconcludeerd worden dat sociale ondersteuning een directe en/of een modererende rol speelt in het stressproces. Bij het opnemen van deze psychosociale variabele in een onderzoek naar de relatie tussen werkaspecten en reacties van verpleegkundigen zullen beide mogelijkheden derhalve nader onderzocht moeten worden.

\section{OPERATTIONALISATTE}

De vragenlijst die sociale ondersteuning meet is evenals die voor gezondheidsklachten afkomstig uit de vos (Reiche en Van Dijkhuizen, 1979). Deze schaal meet met behulp van 22 items, te scoren op een vier-puntsschaal, de mate van sociale steun afkomstig van een vijftal hulpbronnen. Voor gebruik in ons onderzoek is de schaal enigermate aangepast. Zo is ook hier "directe chef" vervangen door "afdelingshoofd" en voorts de bron "directe collega's" gesplitst in "verpleegkundigen van de afdeling" en "leerling-verpleegkundigen van de afdeling". Zo bestaat onze versie van de schaal uiteindelijk uit 27 items die de volgende vijf bronnnen van sociale ondersteuning meten: 
1) steun van verpleegkundigen en leerlingverpleegkundigen (0.84)

2) steun van het afdelingshoofd (0.86)

3) steun van andere mensen op het werk (0.82)

4) steun van vrienden of verwanten $(0.85)$

5) steun van de partner (0.75).

Naast deze vijf-factoroplossing bleek eveneens de twee-factorstructuur duidelijk te interpreteren factoren op te leveren, namelijk:

1) sociale ondersteuning vanuit de werksituatie $(0.86)$

2) sociale ondersteuning vanuit de thuissituatie $(0.80)$.

De eerste factor vertoont een samenstelling wan items die betrekking hebben op het afdelingshoofd, de verpleegkundigen, de leerlingverpleegkundigen en andere mensen op het werk. Be tweede factor behelst die items die informeren naar de steun van vrienden of verwanten en de partner. Aangetoond kon worden dat woor de schaal sociale ondersteuning zowel de twee- als de vijf-factorstructuur goede resultaten opleveren en in beide oplossingen de betrouwbaarheden voldoende zijn.

\subsubsection{Coping}

In de vorige paragraaf hebben we gezien dat sociale ondersteuning die iemand ervaart een rol kan spelen bij het bepalen van de uiteindelijke beleving van stressvolle gebeurtenissen en situaties. Naast de rol van sociale steun wordt binnen de stressbenadering een soortgelijke functie toegeschreven aan copinggedrag: de manier waarop mensen omgaan met de belastende omstandigheden (Pearlin e.a., 1981; Van de Willige e.a., 1983). Het verschil tussen sociale ondersteuning en coping wordt door Pearlin en Schooler (1978) als volgt omschreven:

"Although both are capable of mediating stress, coping is a psychological resource. It resides within the individual. Social support, in contrast, is inextricably bound to interpersonal relationships. It is therefore external to the person; it is an environmental resource."

(Pearlin en Schooler, 1978)

Schreurs e.a. (1984) omschrijven coping als "de inspanningen van een individu indien de aan haar/hem gestelde eisen relevant zijn voor het welzijn (gezondheid, sociaal functioneren en zelfvertrouwen) en wanneer deze eisen een beroep doen op het aanpassingsvermogen". Deze inspanningen verwijzen naar de copingstrategieën die gehanteerd worden zoals "het probleem vermijden" of "actief aanpakken".

Binnen het copingonderzoek bestaan twee verschillende benaderingen, namelijk die betreffende de classificatie van mogelijke copingstrategieën en die betreffende het proces van coping waarbij mogelijke effecten centraal staan (Cox, 1987). In hoofdstuk 2 is gebleken dat studies in de verpleging zich voornamelijk hebben beziggehouden met de classificering van copinggedrag. Onderzoek naar de effectiviteit van coping van verpleegkundigen in de zin van het bewerkstelligen van positieve c.q. negatieve reacties op de arbeidssituatie heeft nog niet plaatsgevonden. Verpleegkundigen komen regelmatig in situaties terecht waarin verrichte handelingen tevergeefs zijn en teleurstellingen verwerkt moeten worden. Van groot belang is dan ook dat verpleegkundigen gebruik maken van effectieve en adequate copingvormen, waardoor de negatieve gevolgen van deze frustraties op gezondheid en psychisch functioneren vermeden kunnen worden. 
De classificatie van copingstrategieên vindt veelal plaats volgens de functie die coping in het stressproces kan hebben. Op dit moment worden daarbij de volgende drie functies onderscheiden:

1. gedrag dat gericht is op het weranderen van de problematische situatie

2. gedrag dat gericht is op de verandering van de perceptie en evaluatie van de bedreigende situatie

3. gedrag dat gericht is op vermindering van de ondervonden spanning

(Pearlin en Schooler, 1978; Pearlin e.a., 1981; Van de Willige e.a., 1982; Thoits, 1986).

Vanuit deze indeling geredeneerd zou men kunnen verwachten dat een copingstrategie zoals "actief-probleem-aanpakken" voornamelijk samenhangt met situationele kenmerken (stressoren), copingstrategieën als "ontkenning", "vermijding" en "geruststellende gedachten" eerder als moderatoren in het proces optreden en een strategie als "meer gaan eten, drinken of roken" vooral invloed uitoefent op de stressreactie. Volgens Schreurs e.a. is het lastig (1984) copingstrategieën wan hun functies te onderscheiden, omdat de meeste copinggedragingen niet uitsluitend of de situatie, of de perceptie en evaluatie of de spanning beïnvloeden. Fleming e.a. (1984) illustreren dit probleem aan het hanteren van de copingstrategie "ontkenning", die als copingstrategie kan inhouden dat of de aanwezigheid van een stressvolle situatie ontkend wordt (situatie-gericht gedrag), 6f de aanwezigheid van de stressvolle situatie wel erkend wordt, maar daarbij ontkend wordt dat deze situatie enige effecten heeft (perceptie-gericht gedrag), of zowel cle stressvolle situatie als de effecten erkend worden, maar de mogelijkheid dat deze effecten ernstig of schadelijk zijn ontkend wordt (spanning-gericht gedrag).

Althoewel uit verschillende onderzoeken naar voren komt dat de manier van omgaan met belastende situaties en gebeurtenissen van invloed is op het psychisch, fysiek en sociaal welzijn van mensen (Pearlin en Schooler, 1978; Cohen en Lazarus, 1979; Pearlin e.a., 1981; Billings en Moos, 1981), kan niet duidelijk gesteld worden dat deze invloed van copingstrategieën middels een hoofd- of bufferwerking plaatsvindt. Tot nu toe is voornamelijk het direct effect van het gebruik van copingstrategieën op stressreacties onderzocht. Bovendien bestaat er op dit moment nog geen eenduidig beeld over de effectiviteit van de verschillende copingstrategieën ten aanzien van diverse situaties en gebeurtenissen. Eveneens is de hantering en het effect van diverse copingstrategieën binnen de arbeidssituatie slechts sporadisch onderzocht (Pearlin en Schooler, 1978; Folkman en Lazarus, 1980; Kompier, 1987).

Met betrekking tot de mogelijke relatie tussen sociale ondersteuming en coping poneren Van de Vliert en De Boer (1984) de hypothese dat "sociale steun via bevestiging van de eigen identiteit probleemoplossend gedrag in de hand werkt, wat uiteindelijk iemands gezondheid ten goede komt". Deze veronderstelling sluit aan bij de gedachtengang van Thoits (1986) die sociale ondersteuning opvat als "coping assistence"; significante anderen kunnen suggesties doen aangaande het toepassen van stressmanagement-technieken dan wel zelf deelnemen aan dergelijke inspanningen en zodoende iemands pogingen tot het omgaan met problematische situaties en gebeurtenissen vergemakkelijken en versterken. Zowel Van de Vliert en De Boer als Thoits gaan er van uit dat sociale ondersteuning het copinggedrag beïnvloedt.

In recentere publicaties ontwikkelen onder andere Dunkel-Schetter e.a. (1987) en Van DamBaggen (1989) daarentegen de visie dat de relatie tussen sociale ondersteuning en coping juist omgekeerd is. Volgens deze onderzoekers verschaft de manier waarop een individu met specifieke stressvolle omstandigheden omgaat de leden van haar of zijn sociale netwerk aanwijzingen aangaande haar of zijn behoeften aan steun. 
Ook al wordt over het algemeen verondersteld, dat sociale steun en coping onderling gerelateerd zijn, over de aard van deze relatie bestaat vooralsnog geen duidelijkheid.

\section{OPERATIONALISATIEE}

Ter operationalisatie van coping is in ons onderzoek gebruik gemaakt van de Nederlandstalige "Utrechtse Coping Lijst" (UCL) van Schreurs e.a. (1984). Als basis voor de ontwikkeling van deze schaal heeft het stressmodel van Van de Willige (1983) gediend. De tot nu toe ondernomen pogingen om coping te meten zijn hoofdzakelijk gebaseerd op de volgende drie themabenaderingen: coping als defensiemechanisme, coping als persoonlijkheidskenmerk of -stijl en coping als interactioneel proces tussen persoon en omgeving. De UCL is het beste te plaatsen onder de opvatting van coping als persoonskenmerk. Dit betekent niet dat copingvormen opgevat worden als onveranderlijke eigenschappen (traits), maar wel dat er vanuit gegaan wordt dat individuen voorkeuren hebben voor bepaalde copingvormen over een aantal situaties heen. De vragenlijstanalyse door Schreurs e.a. toonde aan dat de UCL goede psychometrische eigenschappen bezit. De schaal bestaat uit 47 items ter meting van zeven factoren, als evenzovele manieren van omgaan met problematische gebeurtenissen. De items bestaan uit beschrijvingen van wat men kan denken of doen als zich problemen op het werk voordoen. De respondent wordt gevraagd op een vier-puntsschaal aan te geven hoe vaak zij/hij in het algemeen op het werk op de beschreven manier reageert (varierend van "zeer vaak" tot "zelden of nooit").

De factorstructuur die wij in onze studie vonden bleek de zeven factoren van Schreurs e.a. bijna volledig te repliceren, namelijk:

1) palliatieven $(0.77)^{6}$

2) sociale steun zoeken $(0.78)$

3) actief-probleem-aanpakken (0.75)

4) depressief reactiepatroon $(0.65)$

5) afwachten en vermijden $(0.68)$

6) comforting cognitions $(0.62)^{7}$

7) uiten van emoties $(0.62)$.

\subsubsection{Preferenties}

Bij de bespreking van de taakkenmerkentheorie van Hackman en Oldham (zie 3.3.1) is naar voren gekomen dat individuele behoeften van werknemers mede bepalend kunnen zijn voor de manier waarop mensen op hun werk(situatie) reageren. De variabele die op grond van deze veronderstelling binnen hun "Job Characteristics Model" is opgenomen is "Growth Need Strength": de behoefte die men heeft aan persoonlijke groei en ontwikkeling binnen het werk. De veronderstelling die hier mee samenhangt is dat niet iedere werknemer even enthousiast reageert op complexe en "verrijkte" taken. Hieruit volgt de concrete verwachting dat individuen met een hoge score op "Growth Need Strength" positiever zullen reageren op werk dat hoog scoort op de taakkenmerken, uitgedrukt in de "Motivating Potential Score", dan mensen met een lage "Growth Need Strength".

Tot nu toe is bij het toetsen van de hypothese dat individuele verschillen in de behoefte aan "rijke" functies de relaties tussen taakkenmerken en reacties beïnvloeden, veelal de variabele "Growth Need Strength" van Hackman en Oldham als preferentie gebruikt. Hierop vormen de onderzoeken van bijvoorbeeld Steers en Braunstein (1976), Steers en Spencer (1977) en 
Stone e.a (1977) uitzonderingen in die zin dat andere behoeften als modererende variabelen zijn onderzocht, zoals de behoefte aan onafhankelijkheid, aan prestige, aan autonomie, aan samenwerken en aan leidinggeven.

Het lijkt aannemelijk dat naast de voornamelijk toegepaste variabele "Growth Need Strength" eveneens andere behoeften en daarmee andere preferenties de relatie tussen aspecten van het werk en variabelen zoals tevredenheid beïnwloeden. Zo zal bijwoorbeeld iemand die een sterke behoefte aan samenwerking heeft dit in zijn werksituatie ook tot uitdrukking gebracht willen zien.

\section{OPERATIONALISATLE}

De schaal "preferenties" is ontwikkeld door Algera (1981) en meet zes preferenties voor verschillende aspecten van het werk. De lijst bestaat uit 33 items die betrekking hebben op diverse aspecten van het werk. De respondent moet op een vijf-puntsschaal aangeven hoe aantrekkelijk die aspecten voor haar/hem zijn. De schaalpunten variëren van "uiterst aantrekkelijk" tot "niet aantrekkelijk". De factorstructuur die op basis van onze gegevens kon worden vastgesteld kwam volledig overeen met die van Algera (1981). De zes factoren die geidentificeerd werden, konden conform Algera worden benoemd als:

1) preferentie voor carrière $(0.93)$

2) preferentie voor prestige $(0.89)$

3) preferentie voor autonomie $(0.84)$

4) preferentie voor samenwerken $(0.85)$

5) preferentie voor afwisseling (0.75)

6) preferentie voor het ontbreken van tijdsdruk (0.80).

\subsubsection{Biografische kenmerken}

Deze categorie omvat kenmerken die primair op de levensloop van individuen betrekking hebben; het zijn kenmerken die voor het arbeidsgedrag relevant kunnen zijn (Roe, 1983). Uit het overzicht in hoofdstuk twee van studies die de invloed van biografische kenmerken (zoals leeftijd, opleiding, diensttijd, soort aanstelling, geslacht) in de verpleging hebben onderzocht, blijkt dat deze individuele kenmerken mede bepalend kunnen zijn voor iemands arbeidsbeleving (satisfactie, burnout) en -gedrag (verzuim, verloop). Ook uit studies die in andere werksituaties dan de verpleging zijn verricht (voornamelijk de industrie) blijkt dat biografische kenmerken van invloed zijn op reacties van werknemers zoals arbeidstevredenheid (Gruneberg, 1979). Vele onderzoeken beperken zich echter tot het opsporen van een direct hoofdeffect op reactievariabelen zoals satisfactie. Binnen het onderzoeksveld van de taakkenmerkenbenadering echter heeft men eveneens bekeken of de relaties tussen taakkenmerken en reacties verschillen voor subcategorieën werknemers, die zich onderscheiden in biografische achtergronden. Dit is slechts nagegaan voor enkele variabelen zoals de geografisch-culturele achtergrond (afkomstig van stad of platteland), diensttijd, opleiding, protestants arbeidsethos (Turner en Lawrence, 1965; Blood en Hulin, 1967; Siegel, 1971; Siegel en Ruh, 1973; Wanous, 1974; Katz, 1978a, 1978b; Kemp en Cook, 1983).

Binnen studies naar werkaspecten is de modererende werking van diverse biografische kenmerken tot nu toe verwaarloosd. Niet alleen vanuit theoretisch maar ook vanuit praktisch oogpunt is het belangrijk inzicht te verschaffen in de invloed van dergelijke individuele verschillen tussen werknemers, zowel ter verdere ontwikkeling van theoretische modellen zoals het "Job Charac- 
teristics Model", als voor de toepassing van deze kenmis bij het opzenten en invoeren van werkstructureringsprojecten in de praktijk.

\section{OPERATIONALISATIE}

In de vragenlijst werden gegevens gevraagd met betrekking tot de volgende biografische kenmerken: leeftijd in jaren, geslacht, functie (gediplomeerd versus leerling), opleiding (basis en woortgezette), soort betrekking (fulltime versus parttime), diensttijd in de verpleging, in het ziekenhuis en op de afdeling en werktijd (vaste versus wisselende diensten). Er is gebruik gemaakt van volledig geprecodeerde items. Hierbij wordt de respondent gevraagd bij elk item uit een der antwoordalternatieven te kiezen door een kruisje te zetten in bet betreffende hokje.

\subsection{Reductie van het aantal variabelen}

De 56 variabelen waarmee ons onderzoeksmodel zal worden getoetst, zijn als volgt te verdelen in drie categorieën:

- 9 werkaspecten, namelijk zes taakkenmerken, twee leiderschapsstijlen, en eén factor verpleegsysteem"

- 21 reactie-variabelen, namelijk zes factoren eigen werkwaardering, zeven satisfactiefactoren, vijf gezondheidsfactoren en drie verzuimdimensies;

- 26 individuele/psychosociale variabelen, namelijk zeven copingstrategieên, vijf (of twee)

sociale ondersteuningsfactoren, zes preferenties en acht biografische kenmerken.

Gezien de voorgenomen regressie- en subgroep-analyses moest het aantal variabelen als te uitgebreid beschouwd worden vanwege het te grote risico op type I fout. Ter correctie voor deze kanskapitalisatie bij een zo uitgebreid aantal uit te voeren vergelijkingen, is besloten het aantal variabelen in het model te reduceren. Een beperking van het aantal onafhankelijke variabelen leek ongewenst, omdat hierdoor de beschrijwing van de werksituatie te globaal zou worden. Gekozen is voor een reductie van het grote arantal reactie- en individuele/psychosociale-variabelen.

\subsubsection{Beperking van het aantal reactie-variabelen}

De reductie van het aantal afhankelijke variabelen heeft onder andere platsgevonden door middel van een tweede factoranalyse op de schalen "eigen werkwardering" "arbeidssatisfactie" en beide "gezondheidsschalen", waarbij de scores op de 18 factoren resulterend uit de eerste factoranalyse als de items fungeerden.

Met behulp van deze zogenaamde tweede-orde-factoranalyse (zie bijlage 3 voor een volledig overzicht inclusief factorladingen) zijn de volgende drie factoren te identificeren:

- Factor I, benoembaar als arbeidstevredenheid, blijkt een samenstelling te zijn van de zeven factoren uit de schaal "arbeidstevredenheid" en de factor "algemene werkwoldoening" uit de schaal "eigen werkwaardering".

- Factor II, benoembaar als gezondheidsklachten, bundelt de vijf factoren die psychische en psycho-somatische klachten meten met de factor "ervaren belasting" uit de schaal "eigen werkwaardering". 
- Factor II, benoembaar als eigen werkwaardering, bestaat uit de factoren "interne werkmotivatie", "ervaren betekenis" en "ervaren verantwoordelijkheid", uit de schaal "eigen werkwaardering".

De betrouwbaarheden wan deze drie nieuwe factoren zijn redelijk tot hoog, namelijk respectievelijk $0.80,0.75$ en 0.56 (Cronbach's alpha).

De clustering wan oorspronkelijke factoren afkomstig uit dezelfde schaal onder dezelfde nieuwe factor geeft in feite aan dat de oude factoren niet volledig onafhankelijk van elkaar zijn (zie bijlage 4). Een aantal oude factoren blijken redelijk tot hoog (.40) te intercorreleren. Deze bevinding stemt overeen met hetgeen Algera (1981) vond in zijn onderzoek met gebruik van dezelfde schalen ter meting van satisfactie, eigen werkwaardering en gezondheidsklachten.

Een verdere reductie van het aantal afhankelijke variabelen heeft plaatsgevonden in de groep verzuimindicatoren. Zoals bij de behandeling van de operationalisatie van ziekteverzuim (4.5.3.4) naar voren is gekomen, kunnen op grond van onze data drie verzuimmaten vastgesteld worden, namelijk: totale duur, frequentie en gemiddelde duur. Daar ziekteverzuim slechts één van de afhankelijke variabelen is, lijkt het gewenst ook hier een reductie toe te passen door een keuze voor ến verzuimmaat te maken. Deze keuze kan gebaseerd worden op bevindingen in verzuilmonderzoeken die aangeven dat de verschillende verzuimindicatoren in feite niet door gelijksoortige factoren bepaald worden. Zo lijkt de verzuimfrequentie meer gevoelig voor "casuele" afwezigheid, direct gerelateerd aan de evaluatie van de werksituatie, dan de gemiddelde duur of de totale duur (Brook, 1986), welke laatste in feite een afgeleide maat is van verzuimfrequentie en gemiddelde duur en geen verdere informatie bevat (Smulders, 1980; 1984). In de herformulering van het "Attendance"-model van Steers en Rhodes (1978) kiest Brooke dan ook voor frequentie als verzuimmaat. De verzuimfrequentie zou eerder een indicatie vormen voor "vrijwillige" ("unexcused", "uncertified", "unauthorized", "dillegitimate") afwezigheid, welke beïnvloed wordt door negatieve werkattitudes en -percepties (Chadwick-Jones e.a., 1975; Hammer en Landau, 1981; Larson en Fukami, 1985). Uit een aantal in Nederland verrichte studies (bijvoorbeeld Philipsen, 1969: zie ook Smulders, 1980) blijkt dat verzuimfrequentie voornamelijk gerelateerd is aan soort aanstelling, de taak, organisatie van de werkgroep, delegatie van verantwoordelijkheden, leiderschapsstijl, werkomstandigheden, ploegendienst, uitkeringsvoorwaarden en controle-maatregelen. Gemiddeld duur daarentegen wordt beïnvloed door leeftijd, fysieke werkomstandigheden, mate van persoonlijke en medische begeleiding door organisaties, uitkeringsvoorwaarden en de organisatie van de gezondheidszorgstructuur. De resultaten van het onderzoek wan Johns (1978) stemmen hiermee overeen, in die zin dat de variabele "totale duur" minder voorspeld kon worden uit kenmerken van de werksituatie zoals leiderschapsstijl en taakinhoud dan de variabele "verzuimfrequentie". Resumerend kiezen we op grond van de bevindingen in diverse verzuimstudies als verzuimmaat voor "verzuimfrequentie", omdat verwacht wordt dat deze variabele het beste voorspeld kan worden door onze werkaspecten.

Aldus blijkt het mogelijk de 21 reactie-variabelen te reduceren tot vier variabelen, te weten: arbeidstevredenheid, gezondheidsklachten, eigen werkwaardering en verzuimfrequentie. 


\subsubsection{Beperking wan het antal individuele/psychosociale kenmerken}

Ten behoeve van verdere reductie van het aantal variabelen is uiteindelijk de volgende selectie gemaakt uit de individuele/psychosociale kenmerken:
1) sociale ondersteuning vanuit de werksituatie
2) actief-probleem-aanpakken
3) comforting cognitions
4) palliatieven
5) preferentie voor autonomie.
Deze keuze is per variabele als volgt toe te lichten.

\section{SOCLALE ONDERSTEUNING VANUIT DE WERKSITUATIE}

Daar de schaal "sociale ondersteuning" meerdere ondersteuningsfactoren meet, ligt het voor de hand daaruit én of twee factoren te kiezen. Uit de factoranalyse op de schaal "sociale ondersteuning" komen zowel de twee-factorstructuur als de vijf-factorstructuur als goed interpreteerbaar naar voren. Tevens vertonen zowel de factoren uit de twee-factor-structuur als die uit de vijf-factorstructuur hoge betrouwbaarheden. Binnen de vijf-factorstructuur kunnen in feite de twee factoren van de twee-factorstructuur teruggevonden worden, en wel de factor "sociale ondersteuning vanuit de werksituatie" (van het afdelingshoofd, van de gediplomeerde verpleegkundigen en de leerlingverpleegkundigen en van andere mensen op het werk) en "ondersteuning vanuit de thuissituatie" (van vrienden of verwanten en van de partner). Uit bijlage $5 \mathrm{komt}$ naar voren dat de drie factoren die ondersteuning op de werksituatie meten onderling hoger correleren dan met de twee factoren die ondersteuning in de thuissituatie meten afzonderlijk. Voor de twee "thuissituatie" factoren geld mutatis mutandis hetzelfde. Dit wijst erop dat ook binnen de vijf-factorstructuur in feite twee soorten ondersteuningsvariabelen aanwijsbaar zijn. Vandaar dat wij gekozen hebben voor de twee-factoroplossing, met afbakening van enerzijds steun vanuit de werksituatie en anderzijds steun vanuit de thuissituatie. De argumentatie voor de beslissing om uiteindelijk alleen de ondersteuningsfactor vanuit de werksituatie als "derde" variabele mee te nemen is geheel van praktische aard. Ondersteuning vanuit de thuissituatie vormt bij eventuele toekomstige interventies een moeilijk manipuleerbare factor.

\section{ACTIEF-PROBLEEM-AANPAKKEN, COMFORTING COGNITIONS EN PALLIATIEVEN}

Ter reductie van het zevental factoren van copingstrategieën, die conform Schreurs e.a. (1984) resulteren uit onze factoranalyse van de "Utrechtse Coping Lijst" is gekozen voor de copingstrategieën "actief-probleem-aanpakken", "comforting cognitions" en "palliatieven" gezien hun overeenkomst met de drie functies van coping, namelijk respectievelijk situatie-gericht, perceptie- en evaluatie-gericht en spanning-gericht copinggedrag (zie 4.5.4.2).

\section{PREFERENTIE YOOR AUTONOMIE}

De keuze voor de factor "preferentie voor autonomie" uit de groep preferentiefactoren ligt voor de hand gezien de grote belangstelling binnen de taakkenmerkenbenadering voor de invloed van de moderator "Growth Need Strength". Onze factor "preferentie voor autonomie" komt inhoudelijk overeen met deze moderator. 
Aanvankelijk waren in ons onderzoeksmodel de acht biografische kenmerken ondergebracht bij de groep moderatorvariabelen varwwege de verwachte invloed van deze kenmerken op de relatie tussen de onafhankelijke en afhankelijke variabelen. Theoretische gezien blijft het achterhalen van de aard en omwang van deze invloed interessant. Echter praktisch gezien zijn dit niet-manipuleerbare variabelen. Omdat uit de correlatiematrices (zie bijlage 6) blijkt dat deze variabelen wel verband houden met afhankelijke variabelen en ze daardoor wellicht als verstorende variabelen zullen optreden, is besloten een aantal relevante kenmerken wel op te nemen als controle-variabelen in de regressievergelijkingen. Rekening houdend met hun intercorrelaties is de uiteindelijke keuze uit de individuele kenmerken gebaseerd op de resultaten van multiple regressie-analyses van de acht kenmerken op de vier afhankelijke variabelen. Hierbij worden per afhankelijke variabele die kenmerken geselecteerd die een substantiële (significante) bijdrage leveren aan de voorspelling van de afhankelijke variabelen.

De resultaten van de vier regressievergelijkingen (zie bijlage 7) laten zien dat van de vier afhankelijke factoren de kenmerken "geslacht", "functie", "jaren werkzaam in ziekenhuis", "soort betrekking" als meest relevante predictoren beschouwd moesten worden.

Uiteindelijk is ervoor gekozen de variabelen "geslacht", "functie", "soort betrekking" en "jaren werkzaam in ziekenthuis" mee te nemen als controle-variabelen. In de regressie-analyses zijn de dichotome variabelen "geslacht", "functie" en "soort betrekking" wanzelfsprekend gedummificeerd.

Uit de correlatiematrix van bijlage 5 komt bovendien naar voren dat de biografische kenmerken die uiteindelijk niet meegenomen zijn als controle-variabelen wel redelijk tot hoog correleren met eén of meerdere kenmerken die als controle-variabelen gaan fungeren. Zo correleert de variabele "leeftijd" hoog met "jaren werkzaam in het ziekenhuis" (.65). "Jaren werkzaam op de afdeling" en "jaren werkzaam in de verpleging" correleren eveneens hoog met "jaren werkzaam in het ziekenhuis" (respectievelijk .81 en .73). "Werktijd" vertoont samenhang met "jaren werkzaam in het ziekenhuis" (-.28), met "geslacht" (-.13), en met "soort betrekking" (-.31). Alhoewel deze laatste correlaties niet erg hoog zijn, zijn ze wel significant. Overigens komt de variabele "werktijd" uit de vier regressievergelijkingen niet als relevante predictor naar voren.

\subsection{De onderzoeksvraagstellingen}

In deze paragraaf zal een nadere uitwerking van de probleemstelling van het onderzoek in specifieke onderzoeksvraagstellingen plaatsvinden. Daarbij is gekozen voor een exploratieve aanpak met open vraagstellingen, omdat voor een groot aantal effecten uit ons onderzoeksmodel vooralsnog geen concrete, eenduidige hypothesen ter toetsing opgesteld kunnen worden. Dit hangt samen met het feit dat verschillende variabelen nog niet eerder aan elkaar gerelateerd zijn zoals ons onderzoeksmodel voorstelt. Met name geldt dit voor de (buffer en/of hoofd) werking van de individuele/psychosociale kenmerken in het model. Bestaande kennis over de invloed van deze variabelen is nog onvoldoende. Zo kan men zich bijvoorbeeld afvragen of de variabelen "sociale ondersteuning" en "behoefte aan autonomie" een modererende functie hebben voor alle mogelijke of slechts bepaalde relaties tussen werkaspecten en reacties van verpleegkundigen. Over de effectiviteit van de drie specifieke copingstrategieën is nog minder bekend. Zijn de directe actie-mechanismen het meest effectief of kan perceptie-gericht en/of spanning-gericht copinggedrag eveneens of juist eerder een oplossing bieden? 
Voor een aantal relaties in het model, met name tussen de werkaspecten en de reactie-wariabelen, is het wel mogelijk op grond van de literatuurstudie de vraagstellingen nader aan te vullen met gerichte verwachtingen.

\section{DE ONDERZOEKSWRAAGSTELLINGEN}

Een aantal vraagstellingen is rechtstreeks uit het onderzoeksmodel van deze studie af te leiden en vormt derhalve het primair belang van het onderhavige onderzoek. Naast deze zogenaande kernvragen kan echter een aantal secundaire vraagstellingen opgesteld worden. Allereerst zallen beide primaire onderzoeksvraagstellingen geformuleerd worden en verwolgens de secundaire.

\section{PRIMAIRE VRAAGSTELIINGEN:}

1.Wat is de samenhang tussen de werkaspecten en de reactie-variabelen?

Op grond van aanwijzingen in de literatuur wordt verwacht dat de taakkenmerken "complexiteit/moeilijkheid", "feedback/duidelijkheid", "autonomie", "promotie/groei" en "verzorgende/begeleidende activiteiten" en de sociaal-emotionele leiderschapsstijl positief samenhangen met de reactie-variabelen "arbeidssatisfactie" en "eigen werkwaardering" en negatief gecorreleerd zijn met "gezondheidsklachten" en "verzuimfrequentie". Het taakkenmerk "werkdruk" en de taakgerichte methode van verpleging zullen negatief samenhangen met "arbeidssatisfactie" en "eigen werkwaardering" en positief met "gezondheidsklachten" en "verzuimfrequentie". Ten aanzien van het effect van instrumenteel leiderschap kunnen geen eenduidige verwachtingen geformuleerd worden gezien de inconsistente onderzoeksresultaten in deze tot nu toe.

Bij de bespreking van de variabele "leiderschapsstijl" hebben we gesteld dat de vraag naar het effect van verschillende combinaties van sociaal-emotioneel en instrumenteel leiderschap op reacties van verpleegkundigen interessant zou zijn. Vandaar dat deze vraagstelling apart behandeld zal worden.

\section{Wat is het effect van individuele/psychosociale kenmerken op de reactie-variabelen?}

Zoals uit de behandeling van de literatuur is gebleken kunnen individuele/psychosociale variabelen ofwel een buffer- ofwel een hoofdeffect op reacties van mensen uitoefenen, zodat beide mogelijkheden onderzocht moeten worden. De behandeling van vraagstelling 2 zal dan ook plaatsvinden aan de hand van de volgende drie subvraagstellingen:

2a.Wat is de invloed van de individuele/psychosociale kenmerken op de rellatie tussen de werkaspecten en de reactie-variabelen?

Deze vraagstelling gaat nader in op het buffereffect van de individuele /psychosociale variabelen. Van een buffereffect is dus sprake indien de relaties tussen de werkaspecten en de reactie-wariabelen anders verlopen bij veranderende scores op een derde variabele. Ten aanzien van sociale steun wordt in de literatuur bijwoorbeeld aangenomen dat deze variabele de negatieve samenhang van de werkstressoren met de stressreacties afzwakt. Op grond hiervan wordt in ons onderzoek uitgegaan van de verwachting dat sociale steun de verwachte positieve samenhang tussen werkdruk en gezondheidsklachten afzwakt. Concreet betekent dit 
bijvoorbeeld dat mensen met veel sociale steun in een werksituatie die gekenmerkt wordt door een hoge werkdruk minder gezondheidsklachten ervaren dan mensen met weinig sociale steun. Verder gaan we uit van de verwachting dat de veronderstelde positieve samenhangen tussen de taakkenmerken "complexiteit/moelijkheid", "feedback/duidelijkheid", "autonomie", "promotie/groei" en de reactie-variabelen "arbeidstevredenheid" en "eigen werkwaardering" sterker zijn voor verpleegkundigen met veel behoefte aan autonomie dan voor verpleegkundigen met weinig behoefte aan autonomie. Ditzelfde gelde voor de veronderstelde negatieve correlaties tussen de genoemde taakkenmerken en de reactie-variabelen "gezondheidsklachten" en "verzuimfrequentie".

Naast een dergelijke modererende werking van de individuele/psychosociale variabelen, zal een eventueel hoofdeffect van deze variabelen op de reacties van verpleegkundigen eveneens onderzocht moeten worden. Hierbij zal een antwoord verkregen moeten worden op de volgende twee vraagstellingen.

2b. Wat is de samenhang tussen de individuelelpsychosociale kenmerken en de reactie-variabelen?

Ten aanzien van het effect van sociale ondersteuning wordt op grond van de literatuur verwacht dat deze variabele positief samenhangt met satisfactie en eigen werkwaardering en negatief met gezondheidsklachten en verzuimfrequentie. De vraag naar de samenhang tussen de individuele/psychosociale kenmerken en de reactie-variabelen geeft enig inzicht in het hoofdeffect van deze variabelen op reacties van verpleegkundigen. Echter volgens Buunk en Janssen (1987) moet een gerichte toetsing van een hoofdeffect van variabelen zoals sociale steun en coping plaatsvinden door te controleren voor de invloed van stressbronnen, in ons geval dus werkaspecten. Vandaar dat een tweede vraagstelling ten aanzien van de samenhang tussen de individuele/ psychosociale variabelen en de reactie-variabelen opgesteld kan worden:

2c. Wat is de samenhang tussen de individuele/psychosociale kenmerken en de reactie-variabelen wanneer gecontroleerd wordt voor de invloed van de werkaspecten?

\section{SECUNDAIRE VRAAGSTELLINGEN"}

\section{Wat is de samenhang tussen de werkaspecten onderling?}

Deze vraagstelling is vooral belangrijk omdat een te grote samenhang tussen de verschillende predictoren problemen met betrekking tot de multicollineariteit kan opleveren. Op grond van de literatuurbevindingen bestaat de verwachting dat naarmate men op een verpleegafdeling meer patiëntgerichte verpleging hanteert, er meer sociaal-emotioneel en minder instrumenteel leiderschap toegeschreven wordt aan het afdelingshoofd. Bovendien kan worden verwacht dat beide leiderschapsstijlen nauwelijks samenhang vertonen. Duidelijke verwachtingen met betrekking tot de samenhang tussen taakkenmerken enerzijds en leiderschap en verpleegsysteem anderzijds kunnen niet opgesteld worden.

\section{Wat is de samenhang tussen de reactie-variabelen onderling?}

Op grond van aanwijzingen in de literatuur wordt verondersteld dat de reactie-variabelen: arbeidssatisfactie, eigen werkwaardering, gezondheidsklachten en verzuimfrequentie, onderling samenhangen zullen vertonen. Arbeidssatisfactie en eigen werkwaardering worden ver- 
wacht positief met elkaar samen te hangen en negatief met gezondheidsklachten en veruimfrequentie. Gezondheidsklachten en verzuimfrequentie zullen positief correleren. Opgemerkt dient te worden dat de verschillende subdimensies van eigen werkwaardering, arbeidssatisfactie en gezondheidsklachten tot eén variabele zijn teruggebracht. De resultaten wan het bestudeerd onderzoek hebben daarentegen veelal betrekking op de afzonderlijke subdimensies.

\section{Wat is de samenhang tussen de individuele/psychosociale kenmerken onderling?}

Uit de literatuur komen aanwijzingen dat sociale ondersteuning en coping samenhangen, hetzij doordat sociale steun probleemoplossend gedrag in de hand werkt, hetzij doordat de manier waarop een individu met stressvolle situaties omgaat de leden van haar/zijn sociaal netwerk aanwijzingen verschaft omtrent de bestaandle behoefte aan steun.

6. Welke scores vertonen het verpleegkundig management en de verpleegkundigen op de taakkenmerken en wat zijn de verschillen?

Deze vraagstelling gaat na of er voldoende convergentie bestaat tussen subjectieve beoordelingen van de taakkenmerken door de taakuitvoerders zelf en "objectieve" beoordelingen van de taakkenmerken door buitenstaanders, in ons geval leidinggevenden. Een hoge mate van overeenstemming geeft steun aan de veronderstelling dat taakkenmerken en reacties van verpleegkundigen samenhangen vertonen die onafhankelijk zijn van gemeenschappelijke methode variantie.

\subsection{De analyses}

In deze paragraaf zullen in het kort de statistische analyses besproken worden die gebruikt zijn ter dataverwerking voor de beantwoording van de verschillende onderzoeksvraagstellingen (zie 4.7).

\section{Analysetechniek ten aanzien van vraagstellingen:}

3. Wat is de samenhang tussen de werkaspecten onderling?

4. Wat is de samenthang tussen de reactie-variabelen onderling?

5. Wat is de samenhang tussen de individuele/psychosociale kenmerken onderling ?

$2 b$. Wat is de samenhang tussen de individuele/psychosociale kenmerken en de reactie-variabelen?

Voor het nagaan van de onderlinge samenhang tussen dle werkaspecten en de individuele/psychosociale kenmerken zijn Pearson Product Moment Correlaties (PMCC) berekend. Voor beantwoording van de vragen naar de onderlinge samenhang tussen de reactie-variabelen en de samenhang tussen de individuele/psychosociale kenmerken enerzijds en de reactie-variabelen anderzijds zijn daarentegen partiële correlaties gebruikt, gecorrigeerd voor de vier in het onderzoek opgenomen controle-variabelen "geslacht", "functie", "soort betrekking" en "jaren werkzaam in het ziekenhuis". 
Analysetechiniek ten aanzien van vraagstelling:

1. Wat is de samenhang hussen de werkaspecten en de reactie-wariabelen?

2c. Wat is de samenthang tussen de individuele/psychosociale kenmerken en de reactie-variabelen wanneer gecontroleerd wordt woor de invloed wan de werkaspecten?

De directe invloed van de werkaspecten op de reactie-variabelen is eveneens onderzocht met behulp van partiële correlaties, gecorrigeerd voor de vier controle-variabelen. De correlaties geven een eerste inzicht in de richting en de sterkte van de samenhangen die tussen beide groepen variabelen bestaan.

Voor een verdere beantwoording van vraagstelling 1 zijn stapsgewijze multiple regressie-analyses uitgevoerd ter selectie van een zo efficiënt mogelijke set van predictoren, die samen een zo groot mogelijke proportie variantie voorspellen. Door toetsing van de multiple correlatie coefficiënt $(\mathrm{R})$, de gewichten en de stijging van de $\mathrm{R}$ door toevoeging van nieuwe predictoren vindt een optimale ordening plaats van de predictoren.

Voor beantwoording van vraagstelling $2 \mathrm{c}$ is gebruik gemaakt van biërarchische regressie-analyses, waarbij telkens v6or invoer van het betreffende individuele/psychosociale kenmerk alle negen werkaspecten zijn ingevoerd. Zowel in de regressie-analyses met betrekking tot vraagstelling 1 als met betrekking tot vraagstelling $2 \mathrm{c}$ zijn $\mathrm{n}$ in de allereerste stap de vier controle-variabelen ingevoerd.

Analysetechniek ten aanzien van vraagstelling:

$5 a$. Wat is de invloed van de individuele/psychosociale kenmerken op de relatie tussen de werk-aspecten en de reactie-variabelen?

Om de invloed wan de individuele/psychosociale variabelen op de relaties tussen de werkaspecten en de reactie-variabelen na te gaan is gebruik gemaakt van subgroep-regressie analyses. In deze anallyse worden eerst subgroepen geformeerd door de scores op de derde variabele te splitsen bij de mediaan en op deze manier lage en hoge scoregroepen te creëren. Vervolgens worden afzonderlijke regressie-analyses voor beide subgroepen uitgevoerd. De verschillen tussen de verkregen subgroep-regressie-coëfficiënten worden getoetst met behulp van een t-toets. Voor elke mogelijke predictor - criterium combinatie wordt een subgroepanalyse uitgevoerd.

Analysetechniek ten aanzien van vraagstelling:

6. Welke scores vertonen het verpleegkundig management en de verpleegkundigen op de taakkenmerken en wat zijn de verschillen?

Vraagstelling 6 heeft betrekking op het probleem van de verschillen die zouden bestaan tussen subjectieve (door de verpleegkundigen) en "objectieve" (door het verpleegkundig management) beoordelingen van de zes taakkenmerken. Ter beantwoording van deze vraagstelling zal per taakkenmerk een vergelijking tussen beide beoordelingen moeten plaatsvinden. Aangezien de taakkenmerken betrekking hebben op werkaspecten van de afdeling, worden de analyses uitgevoerd op een hoger aggregatieniveau, namelijk dat van de afdeling. Worden de berekeningen uitgevoerd op individueel niveau, waarbij per taakkenmerk een vergelijking plaatsvindt tussen de score van de hele groep verpleegkundigen en de score van de hele groep managers, dan zou een eventueel gevonden verschil tussen beide scores eveneens toegeschreven kunnen worden aan het bestaan van grote verschillen in de beoordeling binnen de groepen als gevolg 
van bestaande afdelingsverschillen. Voor dit effect kan gecorrigeerd worden door de analyses niet op individueel- maar op afdelingsniveau uit te voeren $(n=36)$, waarbij per taakkenmerk voor elke afdeling een gemiddelde score van de verpleegkundigen ( $v$-score) en een gemiddelde score van het verpleegkundig management ( $\mathrm{m}$-score) berekend wordt. Naast het berekenen van een correlatie (PMCC) tussen de v-score en m-score kan men eveneens de verschillen tussen beide scores nagaan met behulp van paarsgewijze $t$-toetsen.

\subsection{De aggregatieniveaus}

In de vorige paragraaf is reeds ingegaan op verschillen in aggregatieniveaus bij de analyses. Afhankelijk van vraagstelling en soort kenmerken waarmee men de verschillen in arbeidssatisfactie, eigen werkwaardering, gezondheidsklachten en verzuimfrequentie tracht te verklaren, kan men het individu, de afdeling of de organisatie als analyse-eenheid kiezen. In onderzoeken betreffende organisatiekenmerken als determinanten van satisfactie etcetera blijkt over het algemeen de organisatie als eenheid van analyse te worden genomen. Dit is echter niet geheel vanzelfsprekend omdat satisfactie etcetera toch een individueel beleven betreft zodat de invloed van organisatiekenmerken ook analyses op individueel niveau behoeft.

Belangrijk is dat uit de keuze van analyse-eenheid de nodige consequenties worden getrokken ten aanzien van de uitspraken die men kan doen.

Kiest men voor het individu als eenheid, dan dient dit bij de interpretatie van de analyses te resulteren in uitspraken over verschillen in satisfactie etcetera tussen individuen. Is men meer geïnteresseerd in verschillen tussen groepen, afdelingen of organisaties, zijn de analyses op een hoger aggregatieniveau aangewezen.

In eerste instantie werd voor de beantwoording van de vraagstellingen (met uitzondering van vraagstelling 6) besloten de analyses te verrichten op individueel niveau, waarbij dus de individuele scores van de verpleegkundigen op de onafhankelijke variabelen gekoppeld worden aan de individuele scores van diezelfde verpleegkundigen op de afhankelijke variabelen. De reden hiervoor was dat we op individueel niveau kunnen beschikken over een voldoende grote groep respondenten $(n=561)$, zodat bijvoorbeeld voor de regressie-analyses de verhouding tussen de grootte van de onderzoeksgroep en het aantal predictoren gunstig ligt. Bovendien kunnen vraagstellingen 2 en 5 het beste op individueel niveau beantwoord worden, aangezien specifieke kenmerken van individuen als zodanig op individueel niveau een rol spelen en derhalve ook op dat niveau bestudeerd moeten worden.

Toch zijn een aantal redenen te geven om de relaties tussen onafhankelijke en afhankelijke variabelen eveneens te onderzoeken op een hoger aggregatieniveau, namelijk dat van de afdeling $(\mathrm{n}=36)$. Hierbij wordt uitgegaan van de gemiddelde scores van de verpleegkundigen die werkzaam zijn op dezelfde afdeling op zowel de onafhankelijke als afhankelijke variabelen. In de eerste plaats betreffen de variabelen die in ons onderzoeksmodel de groep determinanten vormen, kenmerken van de afdeling en gaat het om de vraag naar verschillen in satisfactie etcetera tussen afdelingen. Eventuele toekomstige interventies zullen uiteraard eerder plaatsvinden op het niveau van de afdeling dan op het niveau van het individu.

Een tweede reden vormt de mogelijkheid dat op afdelingsniveau typisch medische en individuele oorzaken van reacties, met name van verzuim grotendeels worden "uitgemiddeld" (Swanborn, 1981; Smulders, 1984). Zo kan iemand die aan een lichamelijke of psychische 
alandoening lijdt dit uiten in een hoog verzuim, terwijl de arbeidssituatie waarin hij werkt door hem als positief ervaren wordt.

De derde reden heeft specifiek betrekking op verzuim. Verzuim is namelijk meestal scheef verdeeld met gevolg dat in de correlatie- en regressie-analyses de coëfficiënten laag zullen zijn. Echter omdat op een hoger aggregatieniveau de extreme waarden naar het gemiddelde worden toegetrokken en de varianties in de variabelen kleiner zullen zijn, wordt voor verzuim, evenals voor de overige afhankelijke variabelen in casu satisfactie, eigen werkwaardering en gezondheidsklachten, hogere verbanden met andere variabelen verwacht. Ook Algera (1981) vond in zijn onderzoek op functieniveau (vergelijkbaar met ons afdelingsniveau) hogere multiple correlatiecoëfficiënten tussen de taakkenmerken en reactie-variabelen dan op individueel niveau. Deze bevinding is volgens Algera een aanwijzing dat de gemeenschappelijke variantie tussen de onafhankelijke en afhankelijke variabelen meer een reflectie is van de "objectieve" verschillen tussen de functies dan van strikt individuele verschillen in perceptie van en reactie op dezelfde functie.

Het besluit om als hoger aggregatieniveau de afdeling te kiezen en niet het ziekenhuis (organisatie-niveau) is eveneens gebaseerd op het feit dat onze predictoren kenmerken van de afdeling zijn en we geînteresseerd zijn in verschillen in satisfactie etcetera tussen afdelingen. Bovendien zou het om statistische redenen onmogelijk zijn de organisatie als analyse-eenheid te kiezen, omdat het betreffende aantal van 16 ziekenhuizen wellicht te beperkt is voor verantwoorde statistische analyses.

Samenvattend worden de data-analyses ten aanzien van vraagstellingen 1-5 op individueel niveau verricht en ten aanzien van de vraagstellingen 1,3 en 4 eveneens op afdelingsniveau. De analyses ten aanzien van vraagstelling 6 tenslotte zijn reeds uitwoerig behandeld in paragraaf 4.8 en zullen uitgevoerd worden met de afdeling als analyse-eenheid.

\section{NOTEN}

1) Daarmee wordt de grootte van de groep respondenten die gebruikt wordt voor de beantwoording van de vraagstellingen 1-5: 709 - 79 (verpleegkundigen die korter dan 3 maanden werkzaam zijn op de afdeling) - 69 (afdelings- en sub/waarnemende hoofden) $=561$ Voor de berekeningen met ziekteverzuim blijven dan 561-134 $=427$ respondenten over.

2) Voor een overzicht van gemiddelden en standaarddeviaties van de variabelen gemeten met de verschillende schalen wordt verwezen naar bijlage 2 .

3) Voor een uitgebreide behandeling van deze benadering en het model van Hackman en Oldham wordt verwezen naar hoofdstuk 3.

4) Teamverpleging in Nederland onderscheidt zich van Teamverpleging in de Verenigde Staten in die zin dat met deze vorm van verplegen in de Nederlandse situatie een patiënt-gericht systeem en in de Amerikaanse situatie een functionele organisatie bedoeld wordt.

5) Themo duidt op de beoogde doeleinden: therapeutisch en motiverend. Het geeft tevens de plaats aan waar het ontwikkeld is: Technische Hogeschool Eindhoven ontwikkeld Model.

6) Bijvoorbeeld: het zoeken van afleiding, aan andere dingen denken die niet met het probleem te maken hebben, proberen je wat prettiger te voelen.

7) Bijvoorbeeld: bedenken dat anderen het ook wel eens moeilijk hebben, dat er nog ergere dingen kunnen gebeuren, dat na regen zonneschijn komt. 


\section{RESULTATEN "PRIMAIRE ONDERZOEKS- VRAAGSTELLINGEN"}

\subsection{Inleiding}

In dit hoofdstuk wordt verslag gedaan van de resultaten met betrekking tot de primaire vraagstellingen (zie 4.7). Allereerst zal in paragraaf 5.2 een bespreking plaatsvinden van de gevonden samenhangen tussen de werkaspecten en de reactie-variabelen zowel op individueel- als op afdelingsniveau (vraagstelling 1). In paragraaf 5.3 wordt vervolgens de rol van de individuele/psychosociale kenmerken behandeld, waarbij het hoofd- en het buffereffect met elkaar worden vergeleken (vraagstellingen 2).

Zoals uit de bespreking van de operationalisatie in hoofdstuk 4 duidelijk werd, was de groep variabelen in eerste instantie veel uitgebreider. Om statistische redenen heeft een reductie van het aantal variabelen plaatsgevonden, waarmee eveneens een bijdrage wordt geleverd aan de overzichtelijkheid van de gevonden verbanden.

\subsection{De samenhang tussen de werkaspecten en de reactie-variabelen}

\subsubsection{Inleiding}

Voor de beantwoording van de eerste onderzoeksvraagstelling "Wat is de samenhang tussen de werkaspecten en de reactie-variabelen?" is naast partiële correlaties gebruik gemaakt van regressie-analyses (zie 4.8). Bij toepassing van deze statistische methode moet echter voldaan worden aan de volgende voorwaarden.

Op de eerste plaats mag er geen sprake zijn van multicollineariteit in de groep predictoren. Dit zou ertoe leiden dat nieuwe predictoren niet opgenomen kunnen worden in de regressievergelijking omdat ze een te hoge samenhang vertonen met reeds opgenomen predictoren en te weinig eigen variantie gemeenschappelijk hebben met de criteriumvariabelle. In de regressie-analyse wordt hiervoor getoetst met behulp van de tolerantiemaat. Alvorens de resultaten met betrekking tot de eerste vraagstelling te presenteren, zal dan ook nader ingegaan moeten worden op de onderlinge samenhang tussen de werkaspecten (5.2.2).

Op de tweede plaats moet gecontroleerd worden voor een aantal assumpties die de regressieanalyse stelt. Aan de belangrijke assumpties van normaal-verdeling en lineariteit bleken onze data te voldoen. Er was zowel sprake van een normale verdeling van de variabelen (met uitzondering van verzuimfrequentie; zie 5.2.3) als van lineaire verbanden tussen de predictoren criteriumvariabelen.

\subsubsection{De onderlinge samenhang tussen de werkaspecten}

In deze en volgende paragrafen zullen slechts de meest interessante verbanden nader toegelicht worden. Zonodig zullen deze correlaties betrokken worden bij de interpretatie van de 
resultaten van de regressie-analyses en de bespreking van conclusies en praktische aanbevelingen. Aangezien de regressile-analyses op zowel individueel-als op afdelingsniveau zallen worden uitgevoerd (zie 4.8), worden in deze paragraaf de correlaties ook op beide aggregatie-niveaus gepresenteerd en besproken. Tabel 5.1 geeft een overzicht van de intercorrelaties tussen de werkaspecten (met significantie-niveau*s) gebaseerd op de individuele scores.

Trbel 5.1. Intercorrelaties werkaspecten op individueel niveau $(\mathbf{a}=561)$

\begin{tabular}{|c|c|c|c|c|c|c|c|c|c|}
\hline & 1. & 2 & 3. & 4 & 5. & 6. & 7 & 8. & 9 \\
\hline 1. compl/moeith. & $y$ & $.27^{* * *}$ & $25 * 4 *$ & $.15^{* * *}$ & $24^{* * *}$ & $.17^{* * * *}$ & -.02 & $-12^{*}$ & $-.47 * *$ \\
\hline 2. feedb/duidelh & & & -.01 & $.25^{* * *}$ & $.40^{* * *}$ & $.30^{* * *}$ & $.43^{* * *}$ & .04 & $-.16^{* * *}$ \\
\hline 3. werkdrak & & & & $-.13^{* * *}$ & .05 & $.19^{* * *}$ & $-.15 * *$ & $.10^{*}$ & .04 \\
\hline 4. autonomie & & & & & .08 & .07 & .07 & $-.21 * * *$ & $-.17^{* * * 4}$ \\
\hline 5. prom/groel & & & & & & $.25^{* * *}$ & $.19^{* * * *}$ & .01 & $-.14 * *$ \\
\hline 6. verzfbegellact. & & & & & & & $.12^{*}$ & .07 & .08 \\
\hline 7. socin-emotleider & & & & & & & & .01 & -.08 \\
\hline 8. instrum leider & & & & & & & & & $.27 * * *$ \\
\hline 9. taak(ws pat.) verpl. & & & & & & & & & \\
\hline
\end{tabular}

*** $\mathrm{p} \leq 0.001 ; * * \mathrm{p} \leq 0.01 ; * \mathrm{p} \leq 0.05$ (tweexijdig)

In het algemeen zijn de verbamden tussen de onafhankelijke variabelen onderling naar verwachting niet erg hoog, hetgeen gunstig is in verband met het probleem van de multicollineariteit bij de regressie-analyse. De drie hoogste correlaties liggen tussen .40 en .47 ( $p \leq 0.001$ ). Dit zijn de verbanden tussen feedback/duidelijkheid en promotie/groei (.40), tussen feedback/duidelijk heid en sociaal-emotioneel leiderschap (.43) en tussen complexiteit/moeilijkheid en taakgericht (versus patiënt-) verplegen $(-.47)$.

De significante correlaties zijn begrijpelijk. Zo lijkt de positieve correlatie tussen feedback/duidelijkheid en sociaal-emotioneel leiderschap een logische samenhang, aangezien binnen deze stijl van leidinggeven de openheid en bevordering van communicatie tussen verpleegkundigen en afdelingshoofd en tussen verpleegkundigen onderling centraal staat.

De verwachting dat, naarmate men op een verpleegafdeling meer patiëntgerichte verpleging toepast er minder instrumenteel leiderschap toegeschreven wordt aan het afdelingshoofd wordt bevestigd door de positieve correlatie $(.27, \mathrm{p} \leq 0.001)$ tussen de werkaspecten "taakgericht (versus patiënt-) verplegen" en "instrumenteel leiderschap". Deze correlatie betekent concreet dat meer taak- en daaraan gekoppeld dus minder patiëntgerichte verpleging gepaard gaat met een grotere nadruk van het afdelingshoofd op de instrumentele aspecten in zijn leidinggeven. De veronderstelde positieve relatie tussen patiëntgerichte verpleging en sociaal-emotioneel leiderschap zoals aangetoond door Mercx (1975b) kon door ons niet bevestigd worden. Wat dat betreft komen onze bevindingen meer overeen met die van Boekholdt (1981) die na invoering van patiëntgerichte verpleging enkel een verandering constateerde in instrumenteel- en niet in sociaal leiderschapsgedrag. Conform de verwachting blijken beide leiderschapsstijlen niet met elkaar samen te hangen.

Tabel 5.2 geeft de intercorrelaties tussen de werkaspecten op afdelingsniveau weer. Deze correlaties worden bepaald door uit te gaan van de gemiddelde score per afdeling op de variabelen in plaats van de individuele score van de verpleegkundige. Uiteraard is het aantal 
cases waarover de berekeningen worden uitgevoerd op aldelingsniveau kleiner, zodat significantiegrenzen minder snel bereikt zullen worden.

Tabel 5.2. Intercorrelaties werkaspecten op afdelingsmiveau ( $(n=36)$

$\begin{array}{lllllllll}11 . & 2 . & 3 . & 4 . & 5 . & 6 . & 7 . & 8 . & 9 .\end{array}$

\begin{tabular}{|c|c|c|c|c|c|c|c|c|}
\hline 1. compl/moeilh. & $.40^{*}$ & .22 & $.40^{*}$ & $.45^{* *}$ & -.00 & -.07 & $-.38^{*}$ & $-.78 * *$ \\
\hline 2. feedb/dunidelh. & & -.16 & .26 & $.44^{* *}$ & .12 & $.48 * *$ & -17 & $-.47^{*}: *$ \\
\hline 3. werkdruk & & & -.11 & .07 & $45^{* *}$ & -.24 & -14 & .01 \\
\hline 4. autonomie & & & & .20 & -.27 & .05 &. $.34 \%$ &. $.52 * * *$ \\
\hline 5. prom/groei & & & & & .20 & .04 & -.21 & $-.43^{* *}$ \\
\hline 6. verz/begel.act. & & & & & & .13 & .11 & .11 \\
\hline 7. soc.-emot.leider & & & & & & & -.02 & -.22 \\
\hline 8. instrum.leider & & & & & & & & $52^{* \text { th th }}$ \\
\hline 9. taak (vs pat.) werpl. & & & & & & & & \\
\hline
\end{tabular}

*** $\mathrm{p} \leq 0.001 ; * * \mathrm{p} \leq 0.01 ; * \mathrm{p} \leq 0.05$ (tweezijdig)

In grote lijnen komt het patroon van correlaties in tabel 5.2 overeen met dat van tabel 5.1. In het algemeen zijn de verbanden op geaggregeerd niveau gelijk of hoger dan op individueel niveau.

Echter worden ook verbanden aangetroffen die veel lager uitvallen op afdelingsniveau, zoals bijvoorbeeld de relatie tussen complexiteit/moeilijkheid en verzorgende en begeleidende activiteiten en tussen promotie/groei en sociaal-emotioneel leiderschap.

Het feit dat bepaalde variabelen op afdelingsniveau nogal hoge samenhangen vertonen kan problemen geven in de regressie-analyses op dit niveau. Dit geldt vooral voor de correlatie tussen "complexiteit/moeilijkheid" en "taakgericht (versus patiënt-) verpleging".

\subsubsection{Verzuimfrequentie}

Zoals reeds aangehaald in de inleiding van deze paragraaf blijkt de verzuimdimensie "verzuimfrequentie" scheef verdeeld. Dit resultaat is ook in andere onderzoeken gevonden (Schroër e.a., 1982; Smulders, 1984). Smulders attendeert in deze op de scheve verdeling van verzuimde dagen over individuen. In een bepaalde waarnemingsperiode zijn er namelijk veel werknemers zonder verzuim (met een 0-waarde) en een relatief gering aantal met veel verzuim. Het gevolg wan zo'n scheve verdeling is dat er lage correlaties gevonden zullen worden tussen verzuimfrequentie en andere variabelen. Een oplossing voor deze complicatie is transformatie tot een normale verdeling, hetgeen volgens Smulders echter geen effect zou hebben vanwege het grote aantal 0-waarden. Een andere mogelijkheid is uitvoering van de analyses op een hoger aggregatieniveau in plaats van op individueel niveau, zoals reeds is aangegeven in paragraaf 4.9. Zowel de mogelijkheid van transformatie als van aggregatie van de scores op afdelingsniveau zijn nader onderzocht. Tabel 5.3 geeft een overzicht van de verdeling van de oorspronkelijke en getransformeerde variabele "verzuimfrequentie" op individueel niveau. 
scheefheid

1a. vercuinfrequentie

1b. logaritme
1.91

0.30

Uit tabel 5.3 wordt duidelijk dat de logaritmisch getransformeerde variabele "verzuimfrequentie" veel minder scheef verdeeld is dan de oorspronkelijke variabele. Op dezelfde wijze is de geaggregeerde variabele "verzuimfrequentie" op scheefheid gecontroleerd. Tabel 5.4 geeft de verdeling van de oorspronkelijke en getransformeerde variabele op afdelingsniveau.

Tabel 5.4. Verdeling verzuimfrequentie op afdelingswiveau $(n=36)$

\section{scheefheid}

$\begin{array}{ll}\text { 1a. verzumfrequentie } & 0.53 \\ \text { 1b. logarime } & 0.17\end{array}$

Uit tabel 5.4 blijkt dat op de oorspronkelijke variabele "verzuimfrequentie" op afdelingsniveau de normaal-verdeling voldoende benaderd. Bij logtransformatie echter wordt nog meer voor scheefheid gecorrigeerd. Concluderend kan gesteld worden dat zowel op individueel- als op afdelingsniveau de getransformeerde variabele "verzuimfrequentie" het meest de normaalverdeling benadert en derhalve in verdere berekeningen met de getransformeerde variabele gewerkt zal worden.

Overigens correleren de getransformeerde variabelen volgens de verwachting op beide aggregatieniveaus met de oorspronkelijke zéér hoog (zowel op individueel niveau als op afdelingsniveau .94)

\subsubsection{De samenhang tussen de werkaspecten en de reactie-variabelen}

Zoals reeds aangegeven wordt vraagstelling 1 betreffende de samenhang tussen de werkaspecten en de reactie-variabelen achtereenvolgens op individueel- en op afdelingsniveau behandeld.

\section{ANALYSES OP INDIVIDUEEL NIVEAU}

Een eerste indruk van de samenhang tussen de negen werkaspecten en de vier reactie-variabelen is verkregen met behulp van partiële correlaties, gepartialiseerd voor de vier biografische kenmerken ("geslacht"'" "functie", "soort betrekking" en "jaren werkzaam in het ziekenhuis") die in dit onderzoek als controle-variabelen zijn opgenomen (zie 4.6.2). De aldus verkregen bevindingen (zie tabel 5.5) kunnen op deze manier dus niet toegeschreven worden aan verschillen in deze controle-variabelen, aangezien voor hun invloed gecorrigeerd is. 
Tabel 5.5. Partiële correlaties tussen werkaspecten en reactie-variabelen op individueel niveau $(n=561)$ (bij verzuimfrequentie $n=427$ ) a)

reactie-variabelen:

werkaspecten: tevredh. gezklacht werkw. freq(log)

\begin{tabular}{lcccc}
\hline 1. compl./moeilh. & $.18^{* * *}$ & .09 & $.25^{* * *}$ & -.09 \\
2. feedb/duidelh. & $.61^{* * *}$ & $-.26^{* * *}$ & $.30^{* * *}$ & -.08 \\
3. werkdruk & $-.20^{* * *}$ & $.34^{* * *}$ & .01 & $.12^{*}$ \\
4. autonomie & $.27^{* * *}$ &. $.20^{* * *}$ & $.17^{* * *}$ & .04 \\
5. promotie/groei & $.45^{* * *}$ &. .08 & $.26^{* * *}$ & $-.11^{*}$ \\
6. verz/begel.act. & $.19^{* * *}$ & .05 & $.21^{* * *}$ & .00 \\
7. soc.-emot.leider & $.57^{* *}$ & $-.34^{* * *}$ & $.21^{* * *}$ & -.03 \\
8. instrum.leider & .02 & $.13^{* *}$ & .01 & -.00 \\
9. taak(vs. pat.)verpL. & $-.12^{*}$ & -.02 & -.09 & .10
\end{tabular}

*** $\mathrm{p} \leq 0.001 ;{ }^{* *} \mathrm{p} \leq 0.01 ;{ }^{*} \mathrm{p} \leq 0.05$ (tweezijdig);

a) Correlaties zijn gecorrigeerd voor de effecten van de vier controle-variabelen "geslacht", "functie", "soort betrekking" en "jaren werkzaam in het ziekenhuis"

Tabel 5.5 laat zien dat er op individueel niveau over het algemeen vrij hoge samenhangen blijken te bestaan tussen onze werkaspecten en reacties van verpleegkundigen zoals tevredenheid, gezondheidsklachten en eigen werkwaardering. Tevens komt naar voren dat verzuimfrequentie niet significant samenhangt met de werkaspecten, wellicht met uitzondering van de positieve correlatie met werkdruk en het negatief verband met promotie/groei (alhoewel deze correlaties laag zijn, zijn ze significant op 5-procents-niveau).

Het merendeel van de significante correlaties is in de verwachte richting. Zo blijkt dat verpleegkundigen een grotere mate van tevredenheid en eigen werkwaardering, en een geringere mate van gezondheidsklachten ervaren, naarmate de werksituatie zich kenmerkt door meer feedback/duidelijkheid, meer sociaal-emotioneel leiderschap en meer autonomie. Bovendien komt naar voren dat verpleegkundigen meer gezondheidsklachten hebben en minder tevreden zijn, naarmate men onder een grotere werkdruk staat. De werkaspecten "promotie/groei" en "verzorgende en begeleidende activiteiten" hangen positief samen met zowel tevredenheid als eigen werkwaardering. Instrumenteel leiderschap en soort verpleegsysteem blijken nauwelijks samen te hangen met reacties van verpleegkundigen. Voor instrumenteel gericht leidinggeven wordt enkel een significante, alhoewel lage, positieve correlatie met gezondheidsklachten gevonden.

Naast correlaties tussen de werkaspecten en de reactie-variabelen zijn eveneens stapsgewijze regressie-analyses van arbeidstevredenheid, gezondheidsklachten, eigen werkwaardering en verzuimfrequentie uitgevoerd met alle negen werkaspecten als mogelijke predictoren. Hiermee worden voor elk van de vier reactie-variabelen die werkaspecten geselecteerd die het meest bepalend zijn in de voorspelling van reacties van verpleegkundigen. In alle regressievergelijkingen zijn telkens in de eerste stap de biografische kenmerken "geslacht", "functie", "soort betrekking" en "jaren werkzaam in het ziekenhuis" als controle-variabelen ingevoerd. Tabel 5.6 geeft een samenvatting van de resultaten van de vier verrichte regressie-analyses. 
Tabe1 5,6. Stapsgewijze regressig-analyses win tevredentheid, gezondheidsklachten, eigen werkwatering en verzuimfrequentie(log) met alle werkaspecten als predictor-variabelen op individueelnivean ( $\mathrm{n}=561$ ) (bij werzuimfirequentie in $=427$ a)

\begin{tabular}{|c|c|c|c|c|}
\hline predictor: & $\begin{array}{l}\text { criteriunt. } \\
\text { tevredth. }\end{array}$ & gez.ki: & werkw. & freq. $(\log )$ \\
\hline 1. compl/moelh. & $\ldots \ldots$ & .13 & .14 & $\ldots$ \\
\hline 2. feedb./duidelh. & .21 & -.16 & .11 & $\ldots$ \\
\hline 3. werkdruk & -.02 & .23 & $\cdots$ & .12 \\
\hline 4. autonomile & .07 & -.13 & .10 & $\cdots$ \\
\hline 5. promotie/groei & .10 & $\ldots$ & .12 & -.12 \\
\hline 6. werzafbegelact. & $\ldots$ & $\ldots$ & .10 & $\ldots$ \\
\hline 7. soc.-emotileider & .24 & -.23 & .10 & $\ldots$ \\
\hline 8. instrum. leider & $\ldots-.$. & .10 & $\ldots$ & $\ldots$ \\
\hline 9. taak(ws pat.) verpl. & $\cdots$ & $\cdots$ & $\cdots$ & $\cdots$ \\
\hline R bij invoer controle-variabelen & .24 & .07 & .23 & .12 \\
\hline \multicolumn{5}{|l|}{ R bij stapsgewijze regressie } \\
\hline$(p \leq 0.05)$ & .77 & .51 & .45 & .20 \\
\hline $\mathbf{R}^{2}$ & .59 & .26 & .20 & .04 \\
\hline $\operatorname{adj} \cdot \mathbf{R}^{2}$ & .58 & .24 & .18 & .02 \\
\hline
\end{tabular}

a) gecorrigeerd voor de effecten wan de vier controle-variabelen "geslacht", "functie", "soort betrekking" en "jaren werkzaam in het ziekenhuis" in de eerste stap wan de regressie

) beta's

In tabel 5.6 worden voor elke afzonderlijke criterium-variabele achtereenvolgens vermeld: de gestandariseerde regressiegewichten (beta's) van de geselecteerde werkaspecten, de multiple correlatie bij invoer van de vier controle-variabelen, de uiteindelijke multiple correlatie na voltooling van de stapsgewijze regressie, de gekwadrateerde multiple correlatie (werklaarde variantie) en de "adjusted" gekwadrateerde multiple correlatie.

Gezien de multiple correlaties in tabel 5.6 blijkt, zowel voor arbeidstevredenheid, gezondheidsklachten als eigen werkwaardering, een redelijk percentage (respectievelijk $59 \%, 26 \%$ en 20\%) van de variantie verklaard te worden. Ook bij de regressie-analyse blijkt de verzuimfrequentie van weinig betekenis in relatie tot de werkaspecten ( $4 \%$ verklaarde variantie).

In het algemeen bevestigen de resultaten van de vier regressie-analyses de middels partiële correlaties gevonden verbanden tussen de werkaspecten en de betreffende reactie-variabelen (zie tabel 5.5). De resultaten zullen nu per reactie-variabele afzonderlijk behandeld worden.

Vergelijking van tabel 5.5 met tabel 5.6 toont dat voor tevredenheid niet alle daarmee significant gecorreleerde werkaspecten als predictoren in de regressie-analyse geselecteerd worden. De niet-geselecteerde aspecten "complexiteit/moeilijkheid", "verzorgende en begeleidende activiteiten" en "taakgericht (versus patiënt-) verpieging" vertonen lage univariate (gepartialiseerde) verbanden met tevredenheid (respectievelijk .18, .19 en -.12). 
Samenvattend blijkt dat de tevredenheid bij verpleegkundigen in volgorde van belangrijkheid relatief hoger is bij:

- veel sociaal-emotioneel gericht leidinggeven van het afdelingshoofd

- veel feedback/duidelijkheid

- veel mogelijkheden tot promotie/groei

- veel autonomie

- een niet te hoge werkdruk.

Verpleegkundigen blijken relatief weinig gezondheidsklachten te ervaren bij (in volgorde van belangrijkheid):

- een niet te hoge werkdruk

- veel sociaal-emotioneel leiderschap van het afdelingshoofd

- veel feedback/duidelijkheid

- niet te veel complexiteit/moeilijkheid

- veel autonomie

- niet te veel instrumenteel gericht leidinggeven van het afdelingshoofd.

De eigen werkwaardering van verpleegkundigen blijkt relatief hoog te zijn buj (in volgorde van belangrijkheid):

- veel complexiteit/moeilijkheid

- veel promotie/groei

- veel feedback/duidelijkheid

- veel sociaal-emotioneel leiderschap van het afdelingshoofd

- veel autonomie

- veel verzorgende en begeleidende activiteiten.

De verzuimfrequentie blijkt relatief laag te zijn bij (in volgorde van belangrijkheid):

- een niet te hoge werkdruk

- veel promotie/groei.

\section{ANALYSES OP AFDELINGSNIVEAU}

Evenals op individueel niveau zijn op geaggregeerd niveau allereerst de partiële correlaties tussen de werkaspecten en de reactie-variabelen berekend. Tabel 5.7 geeft hiervan een overzicht.

Vergelijking van tabel 5.7 met tabel 5.5 toont dat het overgrote deel van de verbanden op afdelingsniveau hoger is dan op het niveau van het individu. Vanwege het geringere aantal onderzoekseenheden worden de significantiegrenzen echter minder snel bereikt. Alle geaggregeerde correlaties met verzuimfrequentie vallen hoger wit dan de op de individuele scores gebaseerde verbanden. Terwijl aan de ene kant verbanden op afdelingsniveau "wegvallen" (bijvoorbeeld de correlaties tussen sociaal-emotioneel leiderschap en eigen werkwaardering), komen op dit niveau andere verbanden "naar voren" (bijvoorbeeld de samenhangen van taakgericht (versus patiënt-) verplegen met tevredenheid, eigen werkwaardering en verzuimfrequentie). 
Tabel S.7. Partiele correlathes tussen werkaspecten en reactie-variabelen op afdelingsniweau $(\mathbf{n}=36)$ a)

\begin{tabular}{|c|c|c|c|c|}
\hline \multirow[b]{2}{*}{ werkaspecten: } & \multicolumn{4}{|c|}{ reacte-variabelen: } \\
\hline & tevredh. & gez.kl. & werkw. & freq. $(\log )$ \\
\hline 1. conpl/mowilh. & .24 & .23 & $.49^{* *}$ & $-.51 * *$ \\
\hline 2. feedb/duidelh. & $.80^{* * *}$ & -.36 & .29 & -.17 \\
\hline 3. werkdruk & $-37^{*}$ & $.59 * * *$ & .11 & .16 \\
\hline 4. automomie & $.39^{*}$ & -.32 & .21 & -.14 \\
\hline 5. promotie/groelt & $.51 *$ & -.08 & $.45^{*}$ & -.27 \\
\hline 6. verz/begellact. & .12 & .18 & .26 & .17 \\
\hline 7. soc -emot leider & $.60^{\text {*in* }}$ &. $.45^{*}$ & $\therefore .02$ & .18 \\
\hline 8. instrum.leider & -.03 & .11 & -.11 & .10 \\
\hline 9. taak(ws pat.) werpl. & $-.43^{*}$ & .06 & $-39^{*}$ & $.48 * *$ \\
\hline
\end{tabular}

*** $\mathrm{p} \leq 0.001 ; * * \mathrm{p} \leq 0,01 ; * \mathrm{p} \leq 0.05$ (tweezjdig); a) Correlaties zijn gecorrigeerd voor de effecten van de vier controle-variabelen "geslacht", "functie", "soort betrekking" en "jaren werkzaam in thet ziekenhuis"

In tabel 5.8 worden de resultaten van de vier regressie-analyses weergegeven.

Tubel 5.\$. Stapsgewijze regressie-analyses van tevredentheid, gezondheidsklachten, eigen werkwaar-dering en verzuimfrequentie(log) met alle werkaspecten als predictor-variabelen op afdelingsniveau $(n=36)$ a)

\begin{tabular}{|c|c|c|c|c|}
\hline predictor: & $\begin{array}{l}\text { criteriwon: } \\
\text { tevredh. }\end{array}$ & gezkl. & werkw. & freq. $(\log )$ \\
\hline 1. compl/moeilh. & $\left.\ldots+{ }^{*}\right)$ & $\cdots$ & 56 & -.63 \\
\hline 2. feedb./duidelh. & .77 & ...- & $-\cdots$ & $\cdots$ \\
\hline 3. werkdruk &. .22 & .47 & 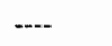 & $\cdots$ \\
\hline 4. autonomie & .28 & $\cdots$ & $\ldots$ & $\cdots$ \\
\hline 5. promotie/groei & $\cdots$ & $\cdots$ & $\ldots$ & $\ldots$ \\
\hline 6. verzdbegelact. & $x=-\infty$ & -..- & - & $-\cdots$ \\
\hline 7. soc-ernot.leider & $\ldots$ & -.31 & $-\ldots$ & $\cdots \cdots$ \\
\hline 8. instrum.lëider & $\ldots$ & $\ldots$ & $\ldots$ & $-\cdots$ \\
\hline 9. taak(ws pat.)verpl. & $\cdots$ & $\ldots . .-$ & $\cdots$ & $\cdots-$ \\
\hline $\mathrm{R}$ bij inwoer controle-variabelen & .12 & .38 & .39 & .13 \\
\hline $\begin{array}{l}\text { R bij stapsgewijze regressie } \\
(p \leq 0.05)\end{array}$ & .86 & .72 & .60 & .52 \\
\hline$\overline{R^{2}}$ & .75 & .52 & .36 & .27 \\
\hline $\mathrm{adj} \cdot \mathrm{R}^{2}$ & .68 & .42 & .24 & .14 \\
\hline
\end{tabular}

a) gecorrigeerd voor de effecten wan de vier controle-variabelen "geslacht", "functie", "soort betrekking" en "jaren werkzaam in het ziekenhuis" in de eerste stap van de regressie; ") beta's 
De percentages verklaarde variantie (voor tevredenheid, gezondheidsklachten, eigen werkwaardering en verzuimfrequentie respectievelijk $75,52,36$ en 27 procent) en de beta's zijn, vergeleken met die op individueel niveau, aanmerkelijk hoger. Dit geldt vooral voor verzulmfrequentie. Het aantal geselecteerde predictoren is bij elke reactie-variabele op geaggregeerd niveau geringer. De bespreking van de uitkomsten van de regressie-analyses zal hierna wederom plaatsvinden voor elke afhankelijke variabele afzonderlijk.

Uit de regressie-analyse van tevredenheid komt naar voren dat evenals op individueel niveau de werkaspecten "feedback/duidelijkheid", "werkdruk" en "autonomie" als meest bepalende factoren te voorschijn komen. In tegenstelling tot de resultaten op individueel niveau behoren de onafhankelijke variabelen "promotie/groei" en "sociaal-emotioneel leiderschap" op geaggregeerd niveau niet tot de groep geselecteerde werkaspecten, ondanks de relatief hoge correlaties die tussen deze variabelen en tevredenheid gevonden worden, namelijk respectievelijk .51 en .60 (zie tabel 5.7). Dit zou het gevolg kunnen zijn van de relatief hoge samenhang van promotie/groei en sociaal-emotioneel leiderschap met de vrij sterke predictor "feedback/duidelijkheid". Ook het werkaspect "taakgericht (versus patiënt-) werplegen" wordt, ondanks de relatief hoge partiële correlatie met tevredenheid (-.43; zie tabel 5.7$)$, niet opgenomen in de regressievergelijking. De samenhang tussen taakgericht (versus patiënt-) verplegen en feedback/duidelijkheid (-.47) is hiervan mogelijk de oorzaak.

Voor gezondheidsklachten geldt, dat die werkaspecten geselecteerd worden die ook op individueel niveau het grootste aandeel bleken te hebben in de voorspelling van gezondheidsklachten, namelijk werkdruk en sociaal-emotioneel leiderschap.

Hetzelfde kan geconstateerd worden voor eigen werkwaardering. Complexiteit/moeilijkheid blijkt de grootste voorspellende waarde te hebben voor deze reactie-variabele. Het feit dat het verpleegsysteem niet opgenomen wordt in de regressievergelijking, ondanks de relatief hoge partiële correlatie tussen deze variabele en eigen werkwaardering $(-39)$, is een gevolg van de vrij hoge samenhang tussen het verpleegsysteem en het taakkenmerk "complexiteit/moeilijkheid" (-.78). Hierdoor blijft voor deze variabele te weinig eigen gemeenschappelijke variantie met eigen werkwaardering over. Ditzelfde geldt voor de predictor "promotie/groei" die ook niet opgenomen wordt in de vergelijking als gevolg van de samenhang met complexiteit/moeilijkheid (.45).

Verzuimfrequentie tenslotte blijkt op afdelingsniveau door complexiteit/moeilijkheid in belangrijke mate voorspeld te worden. Evenals bij eigen werkwaardering het geval was, zorgt de hoge samenhang tussen complexiteit/moeilijkheid en taakgericht (versus patiënt-) verplegen ook in de regressie-analyse van verzuimfrequentie ervoor dat het verpleegsysteem, ondanks de hoge correlatie tussen verpleegsysteem en verzuimfrequentie, geen predictor-functie krijgt.

\subsubsection{De samenhang tussen leiderschapsstijlen en reacties van verpleegkundigen}

Met betrekking tot de samenhang tussen de leiderschapsstijlen van het afdelingshoofd en de reactie-variabelen is in de vorige paragraaf reeds vastgesteld dat, uitgaande van individuele scores, sociaal leidinggeven positief correleert met de tevredenheid en eigen werkwaardering van verpleegkundigen en negatief met gezondheidsklachten, en instrumenteel leiderschia een zwak positief verband vertoont met gezondheidsklachten (zie tabel 5.5). Op afdelingsniveau bleek het leiderschapsgedrag een geringer effect te hebben, in die zin dat enkel sociaal-emo- 
tioneel leiderschap een positieve samenhang bleek te hebben met de tevredenheid en een negatieve correlatie met gezondheidsklachten (zie tabel 5.7).

Gegeven de onderlinge onafhankelijkheid van de twee dimensies van leiderschap (zie tabel 5.1 en 5.2) kan de score op de ene dimensie niet afgeleid worden uit de score op de andere. Vanwege de mogelijkheid van verschillende combinaties van leiderschapsdimensies, is aan de primaire vraagstelling 1 (zie 5.2.4) de volgende subvraag toegevoegd:

"WAT IS DE SAMENHANG TUSSEN COMBINATIES VAN LEIDERSCHAPSSTIJLEN EN DE REACTIE-VARIABELENT

Ter beantwoording van deze vraagstelling is woor elk afdelingshoofd een score bepaald op de sociaal-emotionele- en op de instrumentele leiderschapsstijl door de scores van de verpleegkundigen van de betreffende afdeling te middelen. Vervolgens zijn deze scores bij de mediaan gesplitst en aldus zijn vier klassen (typen) geformeerd namelijk: laag sociaal/laag instrumenteel, laag sociaal/hoog instrumenteel, hoog sociaal/laag instrumenteel en hoog sociaal/hoog instrumenteel (zie figuur 5.1).

\begin{tabular}{|c|c|c|c|}
\hline \multirow{3}{*}{$\begin{array}{l}\text { sociaal- } \\
\text { emotioneel } \\
\text { leiderschap }\end{array}$} & & \multicolumn{2}{|c|}{ instrumenteel leiderschap } \\
\hline & & laag & hoog \\
\hline & laag & groep 1 & groep 2 \\
\hline & hoog & groep 3 & groep 4 \\
\hline
\end{tabular}

Figuur 5.1. De vier typen van leiderschapsstijl

Aan de hand van deze indeling van leiderschapsstijlen zijn de 36 afdelingshoofden ingedeeld in één wan de vier typen. Met behulp van variantie analyses en vervolgens paarsgewijze vergelijkingen van gemiddelden (Scheffe, 1959) is gezocht naar verschillen tussen deze vier groepen op tevredenheid, gezondheidsklachten, eigen werkwaardering en verzuimfrequentie.

Tabel 5.9 geeft de resultaten van de variantie-analyse met tevredenheid als afhankelijke variabele.

Tabel 59. One-way wariantie-analyse (inclusief paarsgewijze vergelijkingen) met de vier combinaties leiderschapsstijlen als onafhankelijke variabele en tevredenheid als afhankelijke wariabele $(F=8.81, D f=3,503, p \leq 0.001)$

Leiderschapsatijl afdelingshoofd tewr. Gemid.

$\begin{array}{ll}\text { groep1: lang sociaal/aag instrumented }(n=147) & 3.47 \\ \text { groep2: lang sociaal/hoog instrumenteel }(n=115) & 3.45 \\ \text { groep3: hoog sociaal/laag instrumenteel }(n=122) & 3.58 \\ \text { groep4: hoog sociaal/hoog instrumenteel }(n=177) & 3.66\end{array}$

Scheffe-toets: 1 4; 2 4 (p $\leq 0.05)$ 
De "overall" F-waarde met bijbehorende overschrijdingskans in tabel 5.9 geeft aan of het gevonden verschil tussen de vier groepen significant is. Aangezten op basis van deze F-wwaarde nog geen uitspraak gedaan kan worden over de vraag tussen welke groepen de verschillen aangetroffen zijn, is middels paarsgewijze vergelijkingen wan de gemiddelden gezocht naar deze specifieke verschillen.

De uitkomst met betrekking tot "tevredenheid" is significant $(F=8.81, p \leq 0.001)$. Uit een nadere bestudering van de resultaten van de paarsgewijze vergelijkingen komt naar voren dat, conform de bevindingen in de correlatiematrices van tabel 5.5 en 5.7 , verpleegkundigen met een afdelingshoofd dat hoog scoort op social-emotioneel leiderschap gemiddeld hoger scoren op tevredenheid. Uit de gegevens van de paarsgewijze vergelijkingen zou men op het eerste gezicht kunnen concluderen, dat bij hoog sociaal leiderschap gemiddeld het hoogst gescoord wordt op tevredenheid, onafhankelijk van de mate van instrumenteel leiderschap (groep 3 en 4 verschillen niet). Echter blijkt ook dat, indien het afdelingshoofd laag scoort op de instrumentele dimensie, het wat betreft de hoogte van de tevredenheid van de verpleegkundigen niet uitmaakt of zij/hij dit combineert met hoog of laag sociaal leiderschap (groepen 1 en 3 verschillen niet). Hieruit kan men concluderen dat de tevredenheid het hoogst is, indien het afdelingshoofd veel aandacht besteedt aan zowel de sociale als de instrumentele aspecten binnen haar/zijn stijl van leidinggeven.

In tabel 5.10 worden de resultaten met betrekking tot gezondheidsklachten gepresenteerd (een hogere score in de tabel betekent meer gezondheidsklachten).

Tabel 5.10. One-way variantie-analyse met de vier combinaties leiderschapsstijlen als onafhankelijke variabele en gezondheidsklachten als afhankelijke variabele $(F=3.10, D f=3,533, p \leq 0.026)$

groep1: laag sociaal/laag instrumenteel $(\mathrm{n}=147)$

groep2: laag sociaal/hoog instrumenteel $(n=115)$

groep3: hoog sociaal/laag instrumenteel $(n=122)$

groep4: hoog sociaal/hoog instrumenteel $(\mathrm{n}=177)$

\subsection{6}

1.75

1.70

1.66

Ook de uitkomst met betrekking tot "gezondheidsklachten" is significant ( $F=3.10, p \leq 0.026)$. Geen van de paarsgewijze vergelijkingen van de gemiddelden blijkt echter significante resultaten op te leveren. Bedacht moet worden dat door correctie voor kanskapitalisatie de Scheffe-toets vrij conservatief is. Bij de "overall" F-toets is de beta-fout (de kans dat de nulhypothese ten onrechte niet verworpen wordt) kleiner, zodat significante resultaten eerder aangetroffen zullen worden. Men kan dus stellen dat er een tendens bestaat dat de combinatie hoog sociaal/hoog instrumenteel leiderschap in de minste gezondheidsklachten resulteert. Bovendien wordt het grootste verschil gevonden tussen groep 1 en 4.

Uit tabel 5.11 komt naar voren dat de eigen werkwaardering wan verpleegkundigen niet verschilt tussen de vier mogelijke combinaties van leiderschapsstijlen. De "overall" F-waarde is niet significant $(\mathbb{F}=1.02, \mathrm{p} \leq 0.384)$. 
Tabel 5.11. One-way variantie-analyste met de vier combinaties leiderschapsstiflen als onafhankelijke variabele en elige werkwarderfag als afhankelijke wariabele $(F=1,02, D f=3,544, p \leq 0.384)$

Leiderschapsotijl afdelingshoofd

werkw. Grewid.

groepl: laag sociaal/laag instrutrented $(n=147) \quad 4.35$

groep2. llag sociaal/hoog instrumentel $(n=1.15) \quad 4.28$

groep3: hoog sociaallaag instrumenteel $(n=122) \quad 4,30$

groeps: hoog sociaal/hoog instrumented $(n=177) \quad 4.34$

Tabel 5.12 laat de resultaten met betrekking tot $(\log )$ verzuimfrequentie zien. Ook deze uitkomst is significant $(\mathrm{F}=6.46, \mathrm{p} \leq 0.001)$.

Tabel 5.12. One-way variantie-analyse (inclusief paarsgewijze vergelijkingen) met de vier combinaties leiderschapsstijlen als onafhankelijkse variabele en werzuimfrequentie (log) als afhankelijke wariabele ( $F=6.46, \mathrm{Df}=3,420$, $p \leq 0.001)$

Leiderschapsstijl afdelingshoofd

freq. $(\log )$ Gemid.

groep1: laag sociaal/latag instrumenteel $(\mathrm{n}=124) \quad 0.23$

groep2: laag sociaal/hoog instrumenteel $(\mathrm{n}=83) \quad 0.36$

groep3: hoog sociaal/aag instrumenteel $(\mathrm{n}=100) \quad 0.30$

groep4: hoog sociaal/hoog instrumenteel $(\mathrm{n}=120) \quad 0.23$

Scheffe-toets: $1 \# 2 ; 2 \# 4(\mathrm{p} \leq 0.05)$

De paarsgewijze vergelijkingen geven aan dat enkel de gemiddelden van groep 1 en 2 van groep 2 en 4 significant verschillen. Op grond hiervan zou men op het eerste gezicht kunnen stellen, dat verpleegkundigen met een afdelingshoofd dat ofwel een hoog sociaal leiderschap combineert met een hoog instrumenteel ofwel een laag sociaal met een laag instrumenteel het minst vaak verzuimen.

Er komt echter tevens naar voren, dat wanneer het hoofd hoog scoort op sociaal leiderschap, het wat betreft de hoogte van de verzuimfrequentie niet uitmaakt of zij/hij dit combineert met hoog of laag instrumenteel leiderschap (groep 3 en 4 verschillen niet). Bovendien geldt dat wanneer een afdelingshoofd laag scoort op instrumenteel leiderschap, de omvang van de verzuimfrequentie onafhankelijk is van de score van het hoofd op sociaal leiderschap (groep 1 en 3 verschillen niet).

\subsubsection{Samenvatting en conclusies}

In deze paragraaf zijn de resultaten met betrekking tot de primaire onderzoeksvraagstelling naar de samenhang tussen de werkaspecten en de reacties van verpleegkundigen uitvoerig aan de orde gesteld. In de behandeling van deze vraagstelling is gebruik gemaakt van partiële correlaties (gecorrigeerd voor het effect van de vier biografische kenmerken "geslacht", "functie", "soort 
betrekking" en "jaren werkzaam in het ziekenhuis") en stapsgewijze multiple regressie-analyses. Controle op de assumpties die aan de toepassing van deze analyses zijn verbonden, bracht an het licht dat verzuimfrequentie, vooral op individueel niveau, volgens verwachting scheef verdeeld is, en derhalve overgegaan moest worden tot log-transformatie van deze variabele. De beide anallyse-technieken zijn uitgevoerd zowel op individueel- als op afdelingsniveau.

Op individueel niveau blijken de negen werkaspecten relatief hoog samen te haiggen met tevredenheid, gezondheidsklachten en eigen werkwaardering en nauwelijks met verzuimfrequentie.

De resultaten van de vier verrichte regressie-analyses op individueel niveau komen overeen met de gegevens van de partiële correlaties op ditzelfde analyse-niveau in die zin dat de gevonden (gekwadrateerde) multiple correlaties voor arbeidstevredenheid, gezondheidsklachten en eigen werkwaardering redelijk hoog zijn (respectievelijk $.59, .26$ en .20) en voor verzuimfrequentie zeer laag (.04). Bovendien blijken in het algemeen die werkaspecten in betekenis te worden geselecteerd die ook significante partiële correlaties met de reactie-variabelen vertonen, zodat op individueel niveau nauwelijks sprake kan zijn geweest van een te hoge multicollineariteit.

Op afdelingsniveau blijken de meeste correlaties tussen de werkaspecten en de reactie-variabelen hoger uit te vallen dan op individueel niveau. Vooral geldt dit voor de verzuimmaat "frequentie". Ook wordt duidelijk dat sommige verbanden op afdelingsniveau verdwijnen, terwijl andere samenhangen dan juist zichtbaar worden. Hiermee kan aangetoond worden dat de invloed van sommige werkaspecten (op bepaalde reacties van verpleegkundigen) op individueel niveau zichtbaar is, terwijl andere werkaspecten daarentegen op afdelingsniveau werkzaam zijn.

Op afdelingsniveau zijn de percentages verklaarde variantie (voor tevredenheid, gezondheidsklachten, eigen werkwaardering en verzuimfrequentie respectievelijk $75,52,36$ en 27 procent) en de beta's in de regressie-analyses volgens verwachting aanzienlijk hoger. Over het algemeen wordt in de vier regressie-analyses op geaggregeerd niveau een geringer aantal werkaspecten geselecteerd. Men kan dus stellen dat op afdelingsniveau een kleiner aantal predictoren in staat is een grotere hoeveelheid variantie in de afhankelijke variabelen te voorspellen dan op individueel niveau.

Uit de vier regressie-analyses blijkt dat op afdelingsniveau over het algemeen die werkaspecten als belangrijkste predictoren geselecteerd worden, die ook op individueel niveau de grootste bijdrage leveren in de voorspelling. Echter zorgen op afdelingsniveau de relatief hoge onder-" linge samenhangen tussen de werkaspecten ervoor dat bepaalde predictoren niet opgenomen worden in de regressie-vergelijkingen, ondanks de relatief hoge correlaties die tussen deze predictoren en de reactie-variabelen gevonden worden.

Ten aanzien van de belangrijkste effecten van de negen werkaspecten op verscheidene reacties van verpleegkundigen kan het volgende geconcludeerd worden. Op individueel niveau is gebleken dat complexe werksituaties met een hoge moeilijkheidsgraad aan de ene kant leiden tot een positieve eigen werkwaardering, maar aan de andere kant ook gezondheidsklachten oproepen. Op afdelingsniveau valt op dat bij een hoge mate van complexiteit/moeilijkheid de verpleegkundigen op verpleegafdelingen een grotere eigen werkwaardering rapporteren en minder vaak verzuimen.

Naast de mate van complexiteit/moeilijkheid blijkt de feedback die men ontvangt van het afdelingshoofd en collega-verpleegkundigen over de taakuitvoering en de duidelijkheid met 
betrekking tot de inhoud van het werk en de te vervullen rol binnen dat werk belangrijk te zijn bij het bepalen van positieve reacties van verpleegkundigen, met uitzondering van verzuimfrequentie. De mate van deze feedback/duidelijkheid blijkt vooral van belangrijke voorspellende waarde ten aanzien van de tevredenheid van verpleegkundigen over hun werk.

Bij een te hoge werkdruk zijn de verpleegkundigen volgens de verwachting minder tevreden, thebben meer gezondheidsklachten en verzuimen vaker.

Een ander aspect in thet werk van verpleegkundigen dat bepalend is voor positieve gevoelens van tevredenheid, erwaren gezondheid en eigen werkwaardering is de mate van autonomie aangaande werkmethoden en -procedures. Gelegenheid voor promotie, groei en persoonlijke ontwikkeling (op tevredenheid, eigen werkwaardering en verzuimfrequentie) blijkt, evenals verzorgende en begeleidende activiteiten (op eigen werkwaardering) enkel op individueel niveau effecten te hebben. Het type verpleegsysteem speelt geen belangrijke rol in de voorspelling van de afhankelijke variabelen. Noch op individueel-noch op afdelingsniveau blijkt het soort verpleegsysteem in de regressie-analyses van de vier reactie-variabelen een bepalende variabele (zie tabel 5.8 en 5.10 ).

Ten alanzien van het leiderschapsgedrag van het afdelingshoofd hebben we kunnen vaststellen, dat sociaal-emotioneel leiderschap in belangrijke mate bijdraagt aan tevredenheid, (vermindering van) gezondheidsklachten en eigen werkwaardering. Instrumenteel leiderschap daarentegen leidt tot meer gezondheidsklachten.

Verder komt uit de verrichte Scheffe-toetsen naar voren dat verpleegkundigen het meest tevreden zijn, wanneer thet afdelingshoofd veel aandacht besteedt aan zowel de sociaal-emotionele als ook de instrumentele aspecten in haar/zijn stijl van leidinggeven. Dit resultaat stemt overeen met de conclusie van auteurs zoals Gruenfeld en Kassum (1973) en Andriessen en Drenth (1982). Dezen stellen namelijk dat "de meest ideale leider beide aspecten van het leiderschap in hoge mate moet waarmaken" (Andriessen en Drenth, 1982).

De bevindingen van Duxbury e.a. (1984) wijken hier echter van af in die zin dat zij vaststelden, dat sociaal leiderschap de satisfactie van de verpleegkundigen positief beïnvloedt, onafhankelijk van de mate van taakstructurend leiderschap.

Uit de Scheffé-toets met verzuimfrequentie wordt duidelijk dat er niet één optimale combinatie van beide leiderschapsstijlen aanwijsbaar is, maar dat een relatief lage verzuimfrequentie bij diverse combinaties voorkomt.

\subsection{De rol van de individuele/psychosociale kenmerken}

\subsubsection{Inleiding}

Nä behandeling van de samenhangen tussen de werkaspecten en de reactie-variabelen, zal nu uitvoerig ingegaan worden op de rol die individuele/ psychosociale kenmerken spelen bij de bepaling van de uiteindelijke reacties van verpleegkundigen op hun werk(situatie). De gevonden relaties tussen de werkaspecten en de reactie-variabelen behoeven immers niet voor iedereen gelijk te zijn (noch wat de aard noch wat de intensiteit van het effect betreft). Bepaalde variabelen, die, althans in ons onderzoek, te beschouwen zijn ofwel als kenmerken van personen ófwel als kenmerken wan de interactie tussen personen en hun omgeving, kunnen mogelijk een modererende werking uitoefenen op de relatie tussen de onafhankelijke en afhankelijke variabelen. Zo kan bijvoorbeeld verwacht worden dat een hoge werkdruk enkel voor personen die weinig steun van collega's ontvangen tot een negatieve reactie, zoals arbeidsontevredenheid, 
leidt. Concreet zou dit betekenen dat sociale steun in feite een beschermende werking heeft in werksituaties waarin men onder hoge druk het werk moet witvoeren. Echter naast of in plaats van een modererende werking kunnen de individuele/psychosociale variabelen een rechtstreeks effect uitoefenen op de reactie-variabelen. Deze directe invloed van dergelijke variabelen zou volgens sommigen (Buunk en Janssen, 1987) pas achterhaald kunnen worden, indien de invloed van kenmerken van de omgeving, in ons geval de werkaspecten, uitgepartialiseerd wordt. In een dergelijkk geval wordt namelijk nagegaan wat bijvoorbeeld de invloed van sociale steun op reacties van verpleegkundigen is, ongeacht de mate van bijvoorbeeld werkdruk en autonomie.

Bij de beantwoording van de primaire onderzoeksvraagstelling 2 naar de rol van de individuele/psychosociale kenmerken (zie 4.7) zullen de drie mogelijke effecten van deze kenmerken op reacties van verpleegkundigen behandeld worden, achtereenvolgens in paragraaf 5.3.2, 5.3.3 en 5.3.4.

\subsubsection{De modererende rol van de individuele/psychosociale kenmerken op de relatie tussen de werkaspecten en de reactie-variabelen}

Ter toetsing van de moderator-functie is gebruik gemaakt van subgroep(regressie)analyses. In deze regressie-analyses zijn wederom telkens de vier controle-variabelen "geslacht", "functie", "soort betrekking" en "jaren werkzaam in het ziekenhuis", ingevoerd. Na deze invoer in de eerste stap, wordt het werkaspect in kwestie als predictor toegevoegd. Vervolgens wordt het verschil tussen de twee verkregen subgroepregressiecoëfficiënten van het betreffende werkaspect met behulp van een t-toets getoetst. Voor alle mogelijke predictor (9) - criterium (4) combinaties is aldus een subgroepanalyse uitgevoerd, resulterend per moderator in 36 subgroepanalyses.

In figuren 5.2 - 5.6 zijn voor de moderator "behoefte aan autonomie" de subgroepanalyses weergegeven die tot significante resultaten hebben geleid, hetgeen dus wil zeggen dat uit de t-toets is gebleken, dat het verschil tussen de subgroep regressie-coëfficiënten (groep met weinig en groep met veel behoefte aan autonomie) significant is. De significante interacties worden in bijlage 8 eveneens in tabel-vorm weergegeven.

Figuren 3.2-5.6. Significante interacties met "behoefte aan autonomie" als moderator,
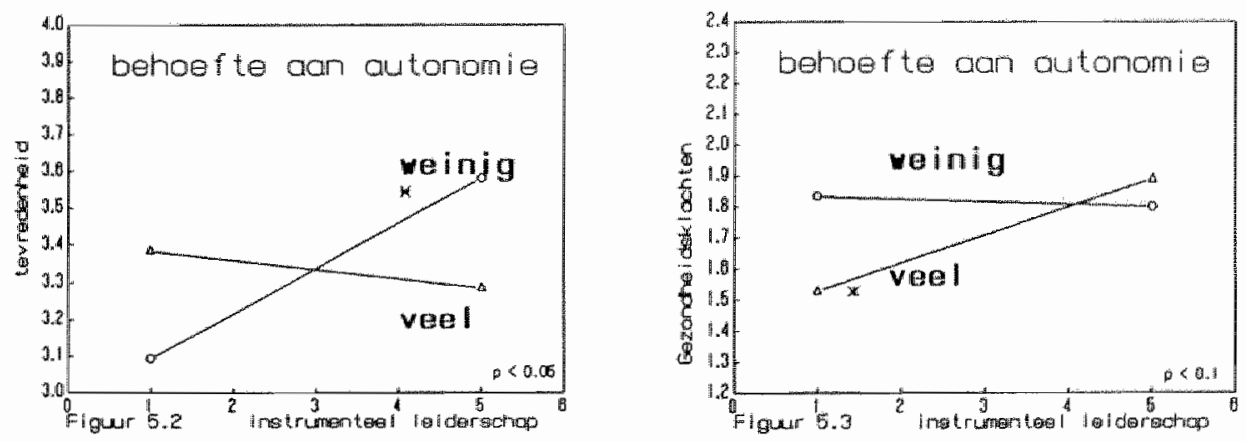

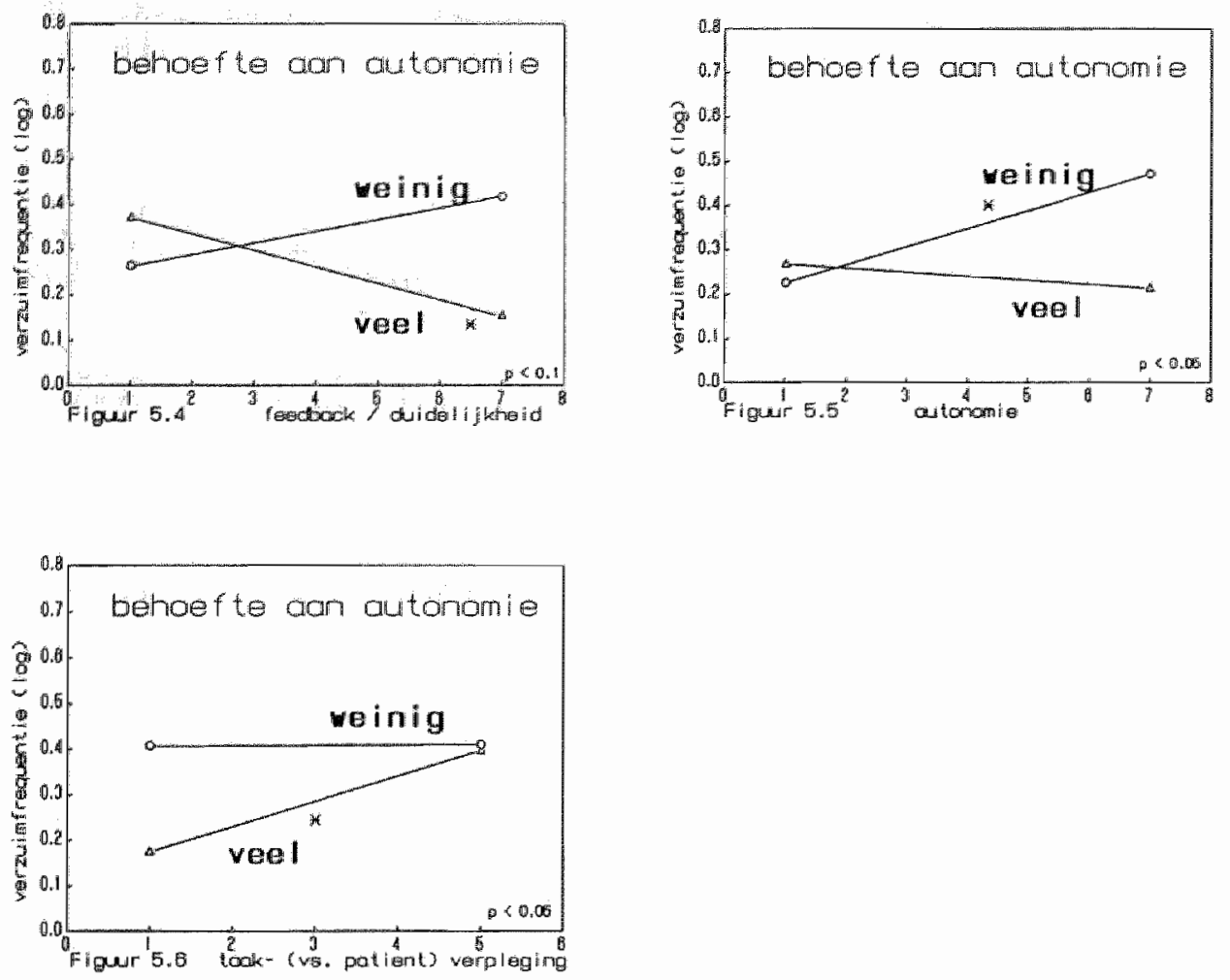

Onderaan de figuren wordt telkens aangegeven op welk niveau de resultaten significant zijn. Vanwege het exploratieve karakter in deze studie met betrekking tot de moderatorfunctie en ter voorkoming van een voortijdige beperking van mogelijke toekomstige onderzoekshypothesen zijn ook gevonden verschillen op 10-procents-niveau opgenomen, waarbij we ons wel degelijk realiseren dat de kans dat de nulhypothese ten onrechte verworpen wordt (type I fout) groot is.

In de figuren is tevens voor de regressie-vergelijkingen aangegeven of de multiple correlatie door toevoeging van de predictor aan de vier controle-variabelen significant verhoogd wordt (" = significante verhoging).

In totaal blijken 5 van de $36(13.9 \%)$ met "behoefte aan autonomie" als moderator uitgevoerde subgroepanalyses significante resultaten op te leveren $(\mathrm{p} \leq 0.1)$. Samengevat laten de resultaten het volgende zien:

* naarmate het afdelingshoofd meer nadruk legt op de instrumentele aspecten in zijn leidinggeven, zijn verpleegkundigen met weinig behoefte aan autonomie tevredener; voor verpleegkundigen met veel behoefte aan autonomie wordt daarentegen geen samenhang tussen instrumenteel leiderschap en tevredenheid aangetroffen.

" naarmate het afdelingshoofd meer nadruk legt op de instrumentele aspecten in zijn leidinggeven, hebben verpleegkundigen met veel behoefte aan autonomie meer gezondheidsklachten; voor verpleegkundigen met weinig behoefte aan autonomie heeft instrumenteel leiderschap daarentegen geen effect op gezondheidsklachten. 
* naarmate er meer feedback en duidelijkheid in de werksituatie asnwezig is, bestaat de tendens ( $\mathrm{p} / \mathrm{Fch}^{1)}$ is namelijk 0.061) dat verpleegkundigen met veel behoefte aan autonomie minder vaak verzuimen; voor verpleegkundigen met weinig behoefte aan autonomie daarentegen heeft dit taakkenmerk geen invloed op de omvang van de verzuimfrequentie.

* naarmate op een verpleegafdeling het werk meer autonomie inhoudt, verzuimen verpleegkundigen die juist weinig behoefte hebben aan autonomie vaker; voor verpleegkundigen met veel behoefte aan autonomie wordt daarentegen geen samenhang gevonden tussen de mate van autonomie en het aantal keren dat men verzuimt.

- naarmate men meer op een functionele taakgerichte wijze de patiënten verpleegt en verzorgt, melden verpleegkundigen met veel behoefte aan autonomie zich vaker ziek; naarmate men echter meer patiëntgerichte verpleging toepast verzuimen deze verpleegkundigen minder vaak. Voor de hoogte van de verzuimfrequentie van verpleegkundigen met weinig behoefte aan autonomie maakt het niet uit op welke manier het werk op de verpleegafdeling georganiseerd is.

De bevindingen ten aanzien van het modererend effect van behoefte aan autonomie op de relatie tussen de taakkenmerken "feedback/duidelijkheid" en "autonomie" en verzuimfrequentie steunen de veronderstellingen die binnen het "Job Characteristics Model" van Hackman en Oldham $(1975,1976)$ ten aamzien van de werking van de "Growth Need Strength"-variabele zijn opgesteld. Werknemers met veel behoefte aan autonomie waarderen meer de aanwezigheid van deze taakaspecten in de werksituatie en reageren dan ook positiever (althans minder negatief in geval van de samenhang tussen autonomie en verzuimfrequentie) dan werknemers met weinig behoefte aan autonomie. Ten aanzien van de relatie tussen het taakkenmerk "autonomie" en verzuimfrequentie zou men echter niet alleen verwacht hebben dat verpleegkundigen met weinig behoefte aan autonomie vaker verzuimen, maar ook dat verpleegkundigen met veel behoefte aan autonomie zich minder vaak ziekmelden, hetgeen niet het geval blijkt.

Daarnaast blijkt, dat in een werksituatie waarin een afdelingshoofd vrij instrumenteel gericht optreedt en patiënten op de traditionele taakgerichte wijze worden verpleegd en verzorgd, verpleegkundigen met veel behoefte aan autonomie meer gezondheidsklachten hebben en vaker verzuimen.

Tenslotte is gebleken dat alleen voor verpleegkundigen met weinig behoefte aan autonomie instrumenteel leiderschap tot een grotere tevredenheid leidt.

Figuren 5.7-5.14 geven de significante resultaten van de subgroepanalyses met "sociale steun vanuit het werk" als moderator weer.

Figuren 5.7-5.14. Significante interacties met "sociale steun vanuit het werk" als moderator.
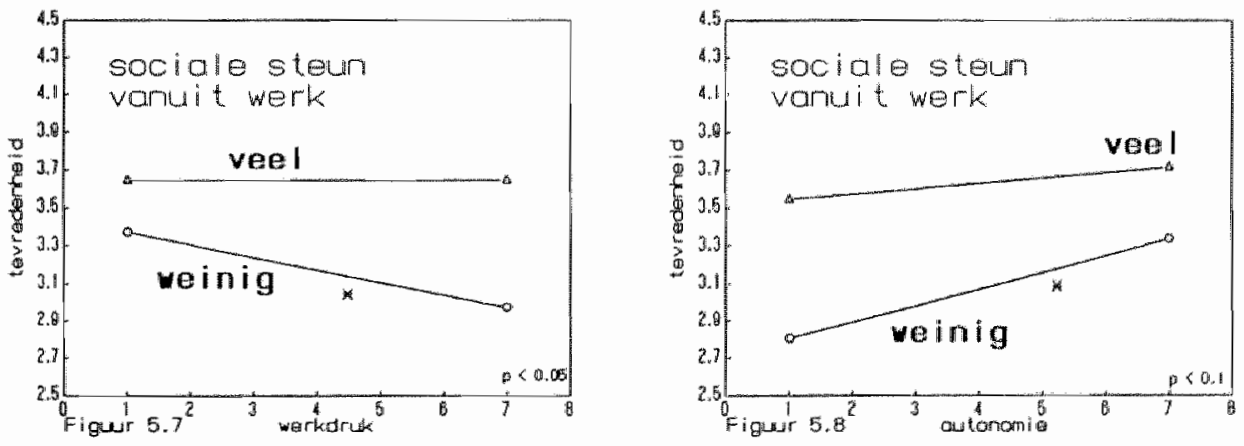

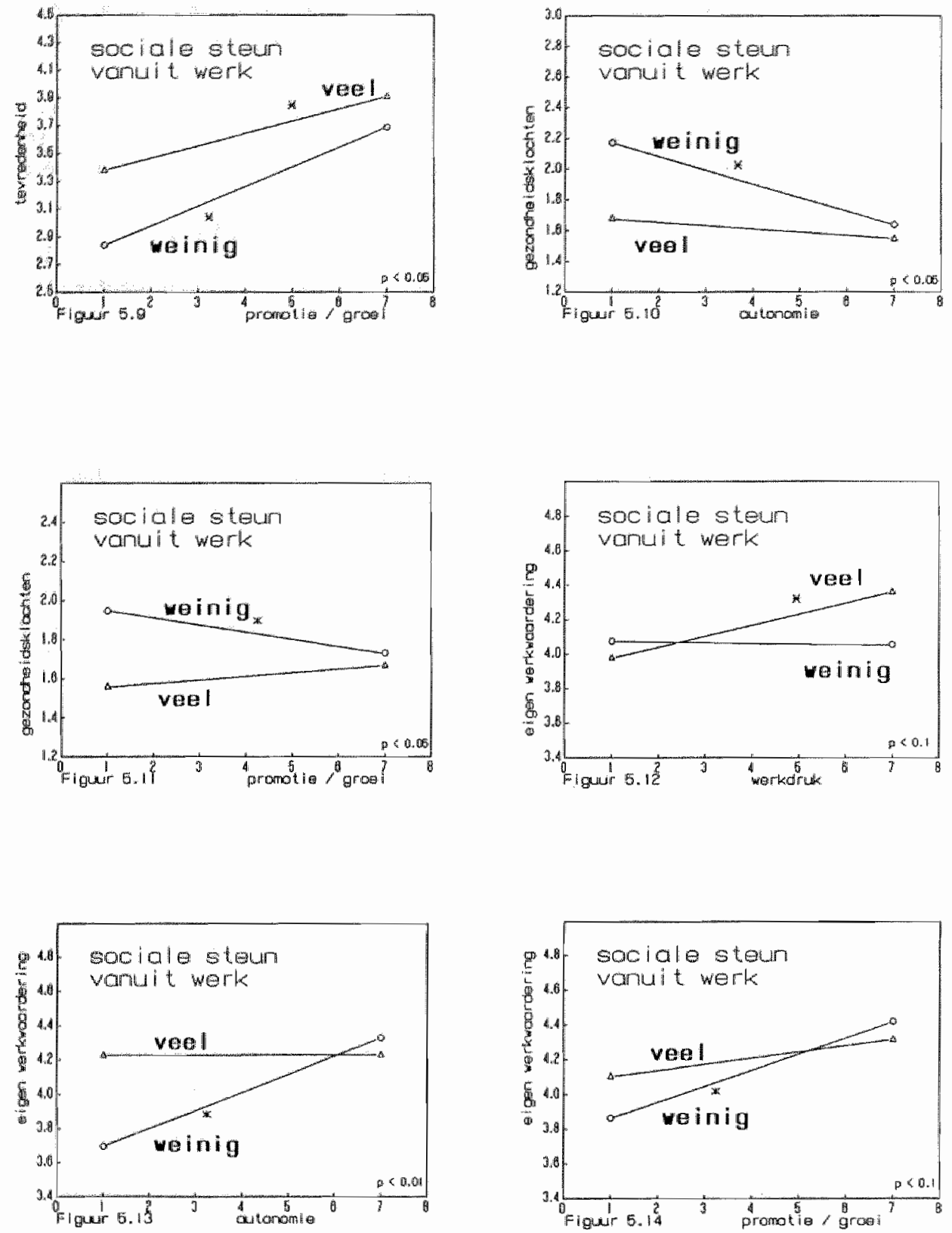
Uit figuren 5.7 - 5.14 (zie ook bijlage 9) blijkt dat, wederom uitgaande van een overschrijdingskans van 10 procent, 8 van de 36 subgroepanalyses significant (22.2\%) zijn. Uit de resultaten van deze acht analyses komt het volgende naar woren:

* naarmate men onder een hogere werkdruk moet werken, zijn verpleegkundigen met weinig ervaren steun minder tevreden; voor verpleegkundigen met veel steun beeft de werkdruk geen invloed op de tevredenheid.

* naarmate men onder hogere werkdruk moet werken hebben verpleegkundigen die veel steun ervaren een positievere eigen werkwaardering; voor personen die weinig steun ondervinden bestaat er geen samenhang tussen de werkdruk en de eigen werkwaardering.

* naarmate men minder autonomie in het werk heeft, hebben verpleegkundigen met weinig steun een geringere tevredenheid, meer gezondheidsklachten en een geringere eigen werkwaardering; voor verpleegkundigen met veel steun op het werk heeft autonomie geen effect op de drie genoemde reacties

* naarmate er minder promotie- en groeimogelijkheden in het werk aanwezig zijn, hebben verpleegkundigen met weinig sociale steun een geringere eigen werkwaardering en meer gezondheidsklachten; de eigen werkwaardering en gezondheid van verpleegkundigen met veel steun wordt daarentegen niet beïnvloed door dit werkaspect.

" naarmate men minder promotie- en groeimogelijkheden in het werk heeft, zijn zowel verpleegkundigen met veel als met weinig steun minder tevreden; de tevredenheid van personen met weinig steun neemt echter veel sterker af bij een geringe kans op promotie/groei.

De uitkomsten van deze significante subgroepanalyses bevestigen op eén na de beschermende bufferfunctie die aan sociale ondersteuning wordt toegeschreven. De bufferhypothese voorspelt namelijk, dat wanneer de stress hoger wordt (in ons geval een hogere werkdruk en een mindere mate van autonomie en promotie/groeimogelijkheden), dit vooral bij gebrek aan steun tot een negatieve reactie zal leiden (LaRocco e.a., 1980). Deze veronderstelling blijkt niet op te gaan voor de modererende werking van steun op de relatie tussen werkdruk en eigen werkwaardering. Toename van de werkdruk blijkt namelijk geen invloed te hebben op de eigen werkwaardering van verpleegkundigen met weinig steun en een relatief hoge positieve invloed op de eigen werkwaardering van verpleegkundigen met veel steun.

Het door ons gevonden percentage significante interacties voor de variabele sociale ondersteuning $(22.2 \%)$ is vergelijkbaar met dat van andere onderzoeken. Uit bijlage 10 wordt duidelijk dat ons percentage zelfs hoger ligt dan dat van andere studies, wanneer men van het totaal aantal getoetste interacties (sociale steun door chef en collega"s samengenomen) per studie uitgaat. Dit geldt zeker als men onze uitkomsten wergelijkt met die van onderzoeken die eveneens in de verpleging verricht zijn (Norbeck, 1985a; Peiro, 1986; Constable en Russell, 1986; Roelens, 1986). Bovendien vertonen in onze studie zeven van de acht significante interacties $(87.5 \%)$ het verwachte buffer-effect, hetgeen op basis van toeval minder zou moeten zijn.

Figuren 5.15 - 5.17 geven een overzicht van de subgroepanalyses met de copingstrategie "actief-probleem-aanpakken" als moderator. 
I"Iguren 5.15-5.17. Significante interacties met "actief-probleem-aanpakken" als moderator.
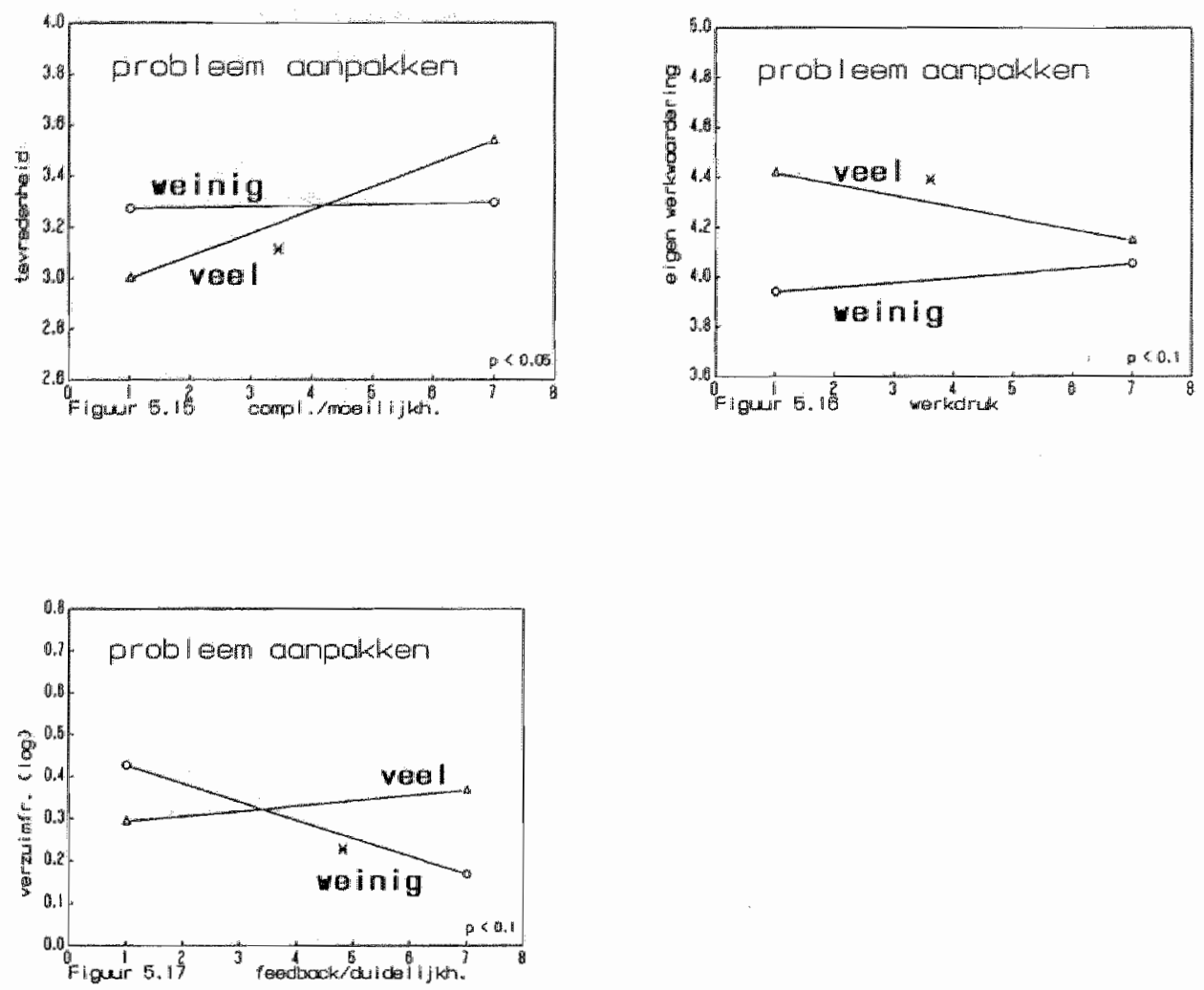

Uit figuren 5.15 - 5.17 (zie ook bijlage 11) wordt duidelijk dat de resultaten met deze moderator minder bevredigend zijn, aangezien het aantal gevonden interacties $(8.3 \%)$ beneden kansniveau ligt. De drie significante subgroepanalyses geven de volgende met het nodige voorbehoud weergegeven interacties aan:

- naarmate de werksituatie op een afdeling complexer/moeilijker wordt, zijn verpleegkundigen met meer actieve aanpak van problematische situaties tevredener; daarentegen hangt voor verpleegkundigen die zelden op deze manier reageren de complexiteit/moeilijkheid niet samen met tevredenheid.

" naarmate de werkdruk hoger wordt, bestaat de tendens dat verpleegkundigen met meer actieve aanpak van problemen een negatievere eigen werkwaardering hebben $(\mathrm{p} / \mathrm{Fch}$ is namelijk 0.101; zie bijlage 11); voor verpleegkundigen die zelden deze aanpak toepassen daarentegen heeft werkdruk geen invloed op de eigen werkwaardering

* naarmate er meer feedback en duidelijkheid in het werk aanwezig is, verzuimen verpleegkundigen die zelden een actieve aanpak hanteren minder vaak; feedback/duidelijkheid heeft 
daarentegen voor verpleegkundigen met meer actieve aanpak geen effect op het aantal keren dat men zich ziekmeldt.

Resumerend blijkt uit onze gegevens dat complexe/moeilijke werksituaties een actieve aanpak van problemen van verpleegkundigen vereisen. Naarmate echter het werk minder complex/moeilijk wordt, leidt deze aanpak tot een geringere tevredenheid. In werksituaties waarin de verpleegkundigen onder zéér grote druk het werk moeten klaren is een actieve aanpak bij zich voordoende problemen mogelijk minder geschikt. Bezien vanuit de items waarmee in deze studie de copingstrategie "actief-probleem-aanpakken" geoperationaliseerd is, impliceert actief ingrijpen voornamelijk dat men doelgericht te werk gaat door het probleem van alle kanten te belichten en verschillende oplossingen tegen elkaar af te zetten. In periodes waarin de werkdruk hoog is, zal men waarschijnlijk geen tijd hebben op een dergelijke weloverwogen wijze in te gaan op problemen die dan optreden.

De bevinding dat een toename in feedback/duidelijkheid alleen voor verpleegkundigen met een geringere actieve aanpak tot een lagere verzuimfrequentie leidt, is vooralsnog moeilijk verklaarbaar. Mogelijk bieden een regelmatige terugkoppeling over het eigen (dis)functioneren en een duidelijke omschrijving van taken, werkprocedures en -methoden aan verpleegkundigen die niet gewend zijn moeilijke situaties zelf op te lossen zoveel houvast en structuur, dat dit hun verzuimfrequentie beperkt.

Figuren $5.18-5.24$ presenteren de resultaten met betrekking tot de copingstrategie "comforting cognitions".

Figuren 5.18-5.24. Significante interacties met "comforting cognitions" als moderator.
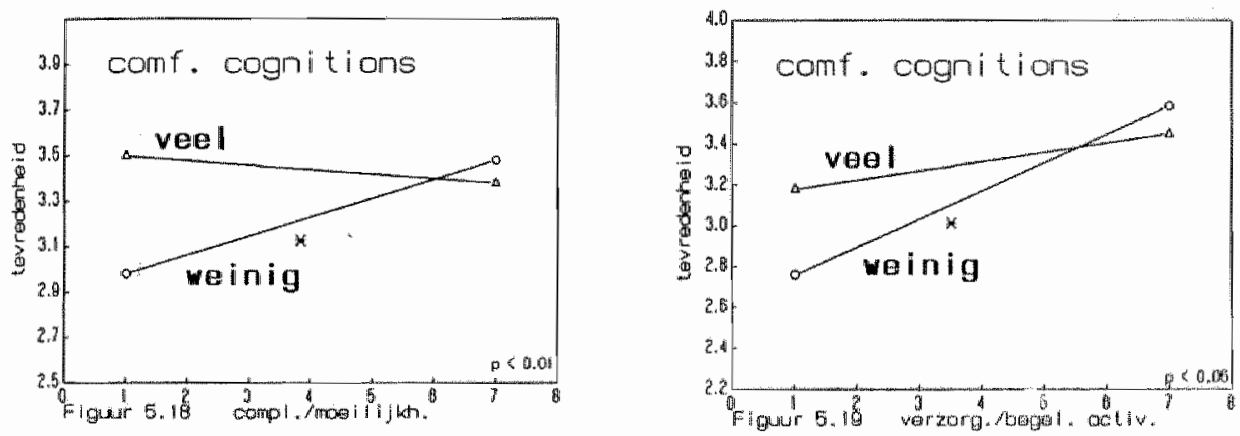

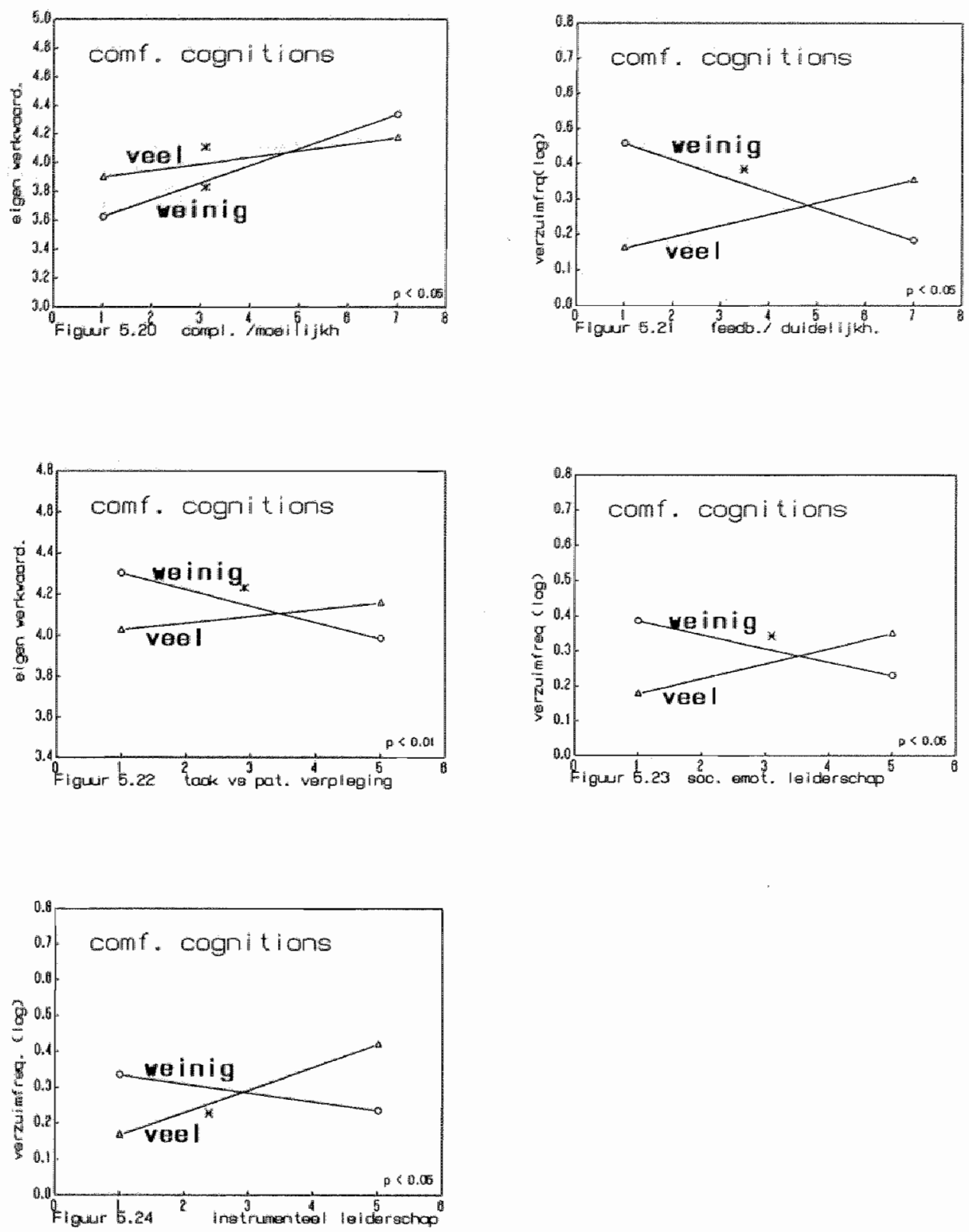
Uit figuren $5.18-5.24$ (zie ook bijlage 12) blijkt dat zeven van de 36 subgroepanalyses (19.4\%) met "comforting cognitions" als moderator significante resultaten opleveren, hetgeen meer is dan als gevolg van kansfluctuaties verwacht kon worden. Deze interacties met betrekking tot de modererende rol van "comforting cognitions" geven het wolgende aan:

* naarmate de complexiteit/moeilijkheid van het werk toeneemt, zijn verpleegkundigen met weinig "comforting cognitions" tevredener; daarentegen wordt voor verpleegkundigen die vaak op deze wijze problemen aanpakken geen samenhang gevonden tussen de mate van complexiteit/moeilijkheid en tevredenheid

* naarmate de werksituatie zich kenmerkt door meer complexiteit/moeilijkheid hebben verpleegkundigen met weinig "comforting cognitions" een positievere eigen werkwaardering; ook voor verpleegkundigen die vaker op deze wijze reageren bestaat een lichte tendens in deze richting ( $\mathrm{p} / \mathrm{Fch}$ is 0.090 ; zie bijlage 12).

* naarmate in een werksituatie meer ruimte is voor verzorgende en begeleidende activiteiten zijn verpleegkundigen met weinig "comforting cognitions" tevredener; voor verpleegkundigen die deze aanpak minder eigen is heeft het werkaspect "verzorgende/begeleidende activiteiten" geen effect op de tevredenheid.

* naarmate men een meer taakgericht dan een patiëntgericht zorgsysteem op de afdeling toepast hebben verpleegkundigen met weinig "comforting cognitions" een minder positieve eigen werkwaardering; voor verpleegkundigen die vaak op deze wijze reageren heeft het type verpleegsysteem geen effect op de eigen werkwaardering

* naarmate een werksituatie gekenmerkt wordt door meer feedback/duidelijkheid en het afdelingshoofd meer nadruk legt op de sociaal-emotionele aspecten van leidinggeven (voor sociaal-emotioneel leiderschap $\mathrm{p} / \mathrm{Fch}$ is 0.089 ; zie bijlage 12 ), verzuimen verpleegkundigen met weinig "comforting cognitions" minder vaak; voor verpleegkundigen die deze coping-strategie veel toepassen wordt geen samenhang aangetroffen tussen deze twee werkaspecten en de omvang van de verzuimfrequentie.

- naarmate het afdelingshoofd meer aandacht besteed aan de instrumentele aspecten van leidinggeven, bestaat de tendens dat verpleegkundigen met meer "comforting cognitions" vaker verzuimen ( $\mathrm{p} / \mathrm{Fch}$ is 0.078 ; zie bijlage 12$)$; voor verpleegkundigen die zelden deze aanpak gebruiken hangt instrumenteel leiderschap niet samen met het aantal keren dat men zich ziekmeldt.

Resumerend kan gesteld worden dat in werksituaties die gekenmerkt worden door: complexiteit/moeilijkheid, aandacht voor verzorgende/begeleidende activiteiten, een meer patiënt- dan taakgericht verpleegsysteem, feedback/duidelijkheid en sociaal-emotioneel, leidinggeven, verpleegkundigen die de copingstrategie "comforting cognitions" weinig toepassen in het algemeen positievere reacties op het werk vertonen. Omgekeerd geldt natuurlijk dat naarmate dergelijke werkaspecten niet c.q. in geringere mate aanwezig zijn, een beperkte gebruikmaking van copinggedrag dat middels geruststelling gericht is op de verandering van de perceptie en evaluatie van de situatie, tot negatievere reacties leidt.

Bovendien is gebleken dat voor personen die vaak deze strategie hanteren praktisch geen relaties worden gevonden tussen onze werkaspecten en de reactie-variabelen, met uitzondering van de positieve samenhang tussen instrumenteel leiderschap en verzuimfrequentie. 
In de 36 subgroepanalyses met de copingstrategie "palliatieven" als moderator bleek geen enkele interactie een significant effect te tonen, zodat aangenomen mag worden dat copinggedrag dat gericht is op vermindering van ondervonden spanining geen modererende rol speelt binnen ons onderzoeksmodel.

\subsection{De individuele/psychosociale kenmerken als hoofdeffect op de reactie-variabelen}

Het directe hoofdeffect van de vijf individuele/psychosociale kenmerken is onderzocht met behulp van partielle correlaties, die wederom gecorrigeerd zijn voor het effect van de vier controle-variabelen (zie tabel 5.13).

Tabel 5.13. Partièle correlaties tussen de individuele/psychosociale kenmerken en de reactie-variabelen op individueel nivean $(n=561)($ biy verzuimfrequentie $n=427)$ a)

\begin{tabular}{lllll}
\hline & tevredh. & gezkl. & werkw. & freq(log) \\
\hline sociale steun & $.65^{* * * * *}$ & $-.38^{* * *}$ & $.28^{* * *}$ & -.04 \\
beh. aan autonomic & -.08 & -.06 & .07 & -.00 \\
palliaticven & -.01 & $.33^{* * *}$ & $.14^{* *}$ & -.01 \\
act.-prob.-aanp. & $.26^{* * *}$ & $-.16^{* * *}$ & $.24^{* * *}$ & -.03 \\
comf.cogn. & .08 & $.11^{*}$ & .09 & .01
\end{tabular}

*** $\mathrm{p} \leq 0.001 ; * * \mathrm{p} \leq 0.01 ; * \mathrm{p} \leq 0.05$ (tweezjdig); a) Correlaties zijn gecorrigeerd voor de effectien van de wier controle-variabelen "geslacht", "functie", "soort betrekking" en "jaren werkzaam in het ziekenhuis"

Uit de correlatiematrix van tabel 5.13 komt naar voren, dat naarmate de verpleegkundigen meer sociale ondersteuning vanuit de werksituatie ervaren, ze hoger op tevredenheid en eigen werkwaardering en lager op gezondheidsklachten scoren. Tussen sociale steun en verzuimfrequentie blijkt geen samenhang te bestaan. Deze resultaten sluiten aan bij de bevindingen van andere onderzoekers (Caplan, 1971; Caplan e.a., 1975; Reiche, 1982; Winnubst e.a., 1982; Gangster e.a., 1986; Chrisholm e.a., 1986). In het algemeen blijkt sociale steun relatief hoge samenhangen met psychische en psycho-somatische reacties (bij ons tevredenheid, gezondheidsklachten en eigen werkwaardering) te vertonen. Een relatie tussen steun en meer gedragsmatige reacties zoals verzuim wordt nauwelijks aangetroffen (Reiche, 1982).

Uitgaande van de theoretische veronderstellingen van Hackman en Lawler (1971) en Hackman en Oldham $(1975,1976)$ is binnen de taakkenmerkenbenadering enkel een modererende werking toegeschreven aan behoefte aan autonomie. Ten aanzien van een hoofdeffect van behoefte aan autonomie op de reactie-variabelen bestonden geen duidelijke verwachtingen. Behoefte aan autonomie blijkt geen samenhang te vertonen met onze reactie-variabelen. Dit wil dus zeggen dat verpleegkundigen met veel behoefte aan autonomie niet hoger of lager scoren op tevredenheid, gezondheidsklachten, eigen werkwaardering en verzuimfrequentie dan verpleegkundigen met weinig behoefte aan autonomie.

In het algemeen worden tussen de drie copingstrategieën en de reactie-variabelen (met uitzondering van werzuimfrequentie) significante, alhoewel lage, verbanden aangetroffen. Zo blijkt dat naarmate de verpleegkundigen meer palliatieve gedragingen vertonen, ze meer gezondheidsklachten rapporteren en een grotere eigen werkwaardering hebben. Ook de copingstrategie "comforting cognitions" correleert positief met gezondheidsklachten. 
Een actieve aanpak van problemen heeft een gunstig effect op drie reacties van verpleegkundigen. Opvallend is dus dat strategieën die niet zozeer gericht zijn op verandering van de situatie, maar veel meer gekenmerkt worden door het zoeken van afleiding (palliatieven) of geruststellend denken ("comforting cognitions"), de psychische en psycho-somatische gezondheidsklachten doen toenemen, terwijl de strategie die gericht is op de aanpak van de problematische situatie de gezondheidsklachten doet afnemen.

Bovendien is een interessante bevinding dat de spanning-reducerende palliatieve aanpak aan de ene kant de eigen werkwaardering bevordert en aan de andere kant de gezondheidsklachten doet toenemen.

\subsubsection{Het effect van de individuele/psychosociale kenmerken op de reactie-varia- belen wanneer gecontroleerd wordt voor de invloed van de werkaspecten}

In de vorige paragraaf is het direct hoofdeffect van de vijf individuele/psychosocialle kenmerken op de reactie-variabelen behandeld. Hier zal nader ingegaan worden op het hoofdeffect van de betreffende kenmerken op de reacties van verpleegkundigen, wanneer gecontroleerd wordt voor de negen werkaspecten. Ter beantwoording van deze vraagstelling is gebruik gemaakt van de (hiërarchische) regressie-analyse, waarbij voor elke afhankelijke variabele in de eerste stap de vier controle-variabelen zijn ingevoerd, gevolgd door de negen werkaspecten en tenslotte door het betreffende individuele/psychosociale kenmerk. Van een hoofdeffect (onder controle van de negen werkaspecten) is pas sprake, wanneer de toevoeging van het betreffende individuele/psychosociale kenmerk in de laatste stap van de regressie-vergelijking een significante toename in de multiple correlatie bewerkstelligt.

Tabel 5.14 geeft een overzicht van de resultaten. In de tabel worden voor elke predictor-criterium combinatie de volgende gegevens gepresenteerd:

- de toename in de gekwadrateerde multiple correlatie na toevoeging van het individuele/psychosociale kenmerk in kwestie

- de F-waarde van de F-toets die nagaat of de toename in de gekwadrateerde multiple correlatie significant afwijkt van nul

- het beta-gewicht dat in dit geval vooral van belang is voor een inzicht in de richting van het gevonden verband. 
Tabel 5;14, Fiêtrchische regressite analyses van tevedentheid, gezondheidshlachten, eigen werkwaardering en wer-

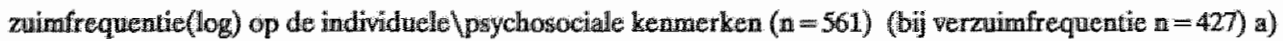

\begin{tabular}{|c|c|c|c|c|}
\hline predictor: & $\begin{array}{l}\text { criteriumis } \\
\text { tevredenh. }\end{array}$ & gez.kl. & wertkw. & freq. $(\log )$ \\
\hline \multirow[t]{3}{*}{ sociale steun } & 1) .04 & .04 & .01 & .00 \\
\hline & 2) 40.34 * * & $17.58 *$ & 2.83 & .004 \\
\hline & 3) .03 & -.27 & .11 & .01 \\
\hline behoefte aan & 1) 01 & .00 & .00 & .00 \\
\hline \multirow[t]{2}{*}{ atonomie } & 2) $4,97^{*}$ & .59 & 1.16 & .23 \\
\hline & 3) -.08 & .04 & .05 & .03 \\
\hline \multirow[t]{3}{*}{ palliatieven } & 1) .00 & .07 & .00 & .00 \\
\hline & 2) $3.87^{*}$ & $38.81^{* * *}$ & .98 & .54 \\
\hline & 3) -.07 & .27 & .05 & -.04 \\
\hline actief-prob. & 1) .00 & .02 & .02 & .00 \\
\hline \multirow[t]{2}{*}{ aanpakken } & 2) 2.30 & $10.61 * * *$ & $8.46 * *$ & .035 \\
\hline & 3) .05 & -.15 & .14 & -.01 \\
\hline comforting & 1) .00 & .02 & .00 & .00 \\
\hline \multirow[t]{2}{*}{ cognitions } & 2) 0.03 & $9.38^{* *}$ & .63 & .06 \\
\hline & 3) .01 & .14 & .04 & .01 \\
\hline
\end{tabular}

*** $\mathrm{p} \leq 0.001 ;$;* $\mathrm{p} \leq 0.01_{\mathrm{j}}^{*} \mathrm{p} \leq 0.05$ (tweezjjdig);

a) gecorrigeerd voor de effecten van de vier controle-variabelen "geslacht", "functie", "soort betrekking" en "jaren werkzaam in het ziekenhuis" in de eerste stap wan de regressie en gecorrigeerd woor de effecten van de negen werkaspecten in de tweede stap

1) toename in de gekwadrateerde multiple correlatie

2) F-waarde bij toename in de gekwadrateerde multiple correlatie

3) beta

Voor het psychosociale kenmerk "sociale steun vanuit de werksituatie" geldt, dat ook na controle van de werkaspecten de invloed op de tevredenheid en gezondheidsklachten van de verpleegkundigen blijft bestaan. Bij eigen werkwaardering valt deze invloed echter weg. Met andere woorden in een werksituatie die wat betreft onze negen werkaspecten voor alle verpleegkundigen gelijk is, vertoont sociale steun geen samenhang met de eigen werkwaardering.

Na correctie voor de werkaspecten blijkt tussen behoefte aan autonomie en tevredenheid een negatieve samenhang te bestaan. Dit resultaat, dat afwijkt van de niet-significante partiële correlatie die tussen beide variabelen is gevonden (zie tabel 5.13), geeft aan dat naarmate men meer preferentie voor autonomie heeft, men minder tevreden is met het werk, gegeven een werksituatie die voor iedereen gelijk is wat betreft onze negen werkaspecten. Zeker in de verpleging zijn personen die in het werk ten aanzien van bijvoorbeeld procedures en methoden veel zelf wensen te bepalen minder snel tevreden te stellen. Vooral op de traditionele verpleeg- 
afdeling, die zich kenmerkt door een taakgerichte en vrij gestructureerde organisatie, bestaat er weinig ruimte voor een eigen aanpak.

De palliatieve copingstrategie vertoont, na correctie van de werkaspecten, een negatieve relatie met tevredenheid (niet aangetroffen in tabel 5.13) en een positieve samenhang met gezondheidsklachten. De positieve partiële correlatie tussen deze strategie en eigen werkwaardering (zie tabel 5.13) valt na correctie van de werkaspecten echter weg.

De copingstrategie "actief-probleem-aanpakken" blijft ook na correctie een gunstig effect uitoefenen op zowel gezondheidsklachten als op eigen werkwaardering; de invloed op de tevredenheid daarentegen verdwijnt.

"Comforting cognitions" tenslotte blijft na correctie slechts positief gecorreleerd met gezondheidsklachten.

\subsubsection{Samenvatting en conclusies}

In deze paragraaf is de rol van de individuele/psychosociale kenmerken binnen ons onderzoeksmodel nader onderzocht. Hierbij is in eerste instantie het buffereffect van deze variabelen bestudeerd en vervolgens is gekeken naar het hoofdeffect. Tabel 5.15 geeft een kort overzicht van de desbetreffende significante resultaten in percentages.

Tabel 5.15. Overzicht van de significante resultaten met betrekking tot de rol van de individuele/psychosociale kenmerken in percentages

\begin{tabular}{lcll}
\hline & $\begin{array}{l}\text { subgroep- } \\
\text { regressie- } \\
\text { analyses }(\%)\end{array}$ & $\begin{array}{l}\text { partièle } \\
\text { correlaties } \\
(\%)\end{array}$ & $\begin{array}{l}\text { hiërarchische } \\
\text { regressie- } \\
\text { analyses }(\%)\end{array}$ \\
\hline behoefte aan autonomie & 13.9 & 0 & 25 \\
sociale steun & 22.0 & 75 & 50 \\
palliatieven & 0 & 50 & 50 \\
actief-prob.-aanpakken & 8.3 & 75 & 50 \\
comforting cognitions & 19.4 & 25 & 25 \\
\hline
\end{tabular}

Voor elk individuele/psychosociale kenmerk zijn telkens 36 subgroepregressie-analyses (ter bestudering van het buffereffect gecorrigeerd voor de vier controle-variabelen), 4 partiële correlaties (ter bestudering van het hoofdeffect gecorrigeerd voor de vier controle-variabelen) en 4 hierarchische regressie-analyses (ter bestudering van het hoofdeffect gecorrigeerd voor de vier controle-variabelen en de negen werkaspecten) uitgevoerd.

Voor de toetsing van de moderatorfunctie is de 10-procentsgrens als significantieniveau aangehouden om redenen genoemd in 5.3.2 en voor de toetsing van het hoofdeffect de 5-procentsgrens. De toetsing van het hoofdeffect is krachtiger, waardoor het gerechtvaardigd lijkt een kleinere overschrijdingskans als grens te hanteren. In de subgroepanalyses daarentegen wordt het onderscheidingsvermogen van de toets gereduceerd door splitsing van de oorspronkelijke onderzoeksgroep in tweeën bij de mediaan met een kleinere kans op significante uitkomsten vandien. Handhaving van de 10 -procentsgrens voorkomt dat mogelijk inte- 
ressante interacties onvermeld blijven. Uiteraard moeten gevonden interactie-effecten op dit niveau met enige zorgvuldigheid bezien worden.

De resultaten met betrekking tot de direct uit het "Job Characteristics Model" van Hackman en Oldham $(1975,1976)$ af te leiden variabele "behoefte aan autonomie" zijn minder bevredigend. Slechts 13.9 procent van de interacties tussen deze preferentie-variabele en de werkaspecten is significant, hetgeen praktisch op kansniveau ligt. Desondanks zijn de gevonden interacties in de verrichte subgroepanalyses duidelijk interpreteerbaar en in lijn der verwachting. In het algemeen blijkt namelijk dat werpleegkundigen met veel behoefte aan autonomie positiever (of minder negatief) reageren op werk dat zich kenmerkt door veel feedback/duidelijkheid, autonomie, patiëntgerichte verpleging en een lage mate van instrumenteel gericht leiderschap. De bestudering van het hoofdeffect van behoefte aan autonomie, volledigheidshalve in deze studie aan het "Job Characteristics Model" toegevoegd, levert slechts één significant resultaat op. Alleen onder constanthouding van de negen werkaspecten hangt behoefte aan autonomie positief samen met tevredenheid.

De resultaten met betrekking tot de werking van sociale ondersteuning vanuit de werksituatie zijn redelijk positief. Zeven van de acht significante interacties geven conform het verwachte buffereffect aan dat sociale steun in meer of mindere mate "bescherming" kan bieden tegen:

- een te hoge werkdruk (met betrekking tot tevredenheid)

- een gebrek aan autonomie (met betrekking tot tevredenheid, gezondheidsklachten en eigen werkwaardering)

- een gebrek aan promotie/groeimogelijkheden (met betrekking tot tevredenheid en eigen werkwaardering).

Bovendien is gevonden dat sociale steun de tevredenheid en eigen werkwaardering van verpleegkundigen bevordert en hun psychische en psycho-somatische gezondheidsklachten reduceert. Onder constanthouding van de negen werkaspecten valt de samenhang tussen sociale steun en eigen werkwaardering weg. Dit betekent dat in werksituaties die wat betreft onze negen werkaspecten niet verschillen, sociale steun geen effect heeft op de eigen werkwaardering van de verpleegkundigen.

Eveneens is de rol van copingstrategie "palliatieven" behandeld. Er werden geen significante interacties aangetroffen. Verder is gebleken dat een palliatieve spanning-reducerende aanpak, gecorrigeerd voor de vier controle-variabelen, gezondheidsklachten bevordert, maar een positievere eigen werkwaardlering bewerkstelligt. Wordt daarentegen eveneens gecorrigeerd voor de werkaspecten, dan blijft de positieve samenhang met gezondheidsklachten bestaan. Bovendien blijkt dan dat deze manier van aanpak wan problemen tot geringere tevredenheid leidt.

Het aantal gevonden interacties met betrekking tot de copingstrategie "actief-probleem-aanpakken" ligt duidelijk beneden kansniveau ( $8.3 \%$ ). Daar de drie significante interacties mogelijk het gevolg zijn van kansfluctuaties wordt niet verder ingegaan op de modererende rol van deze copingstrategie. De uitkomsten van de toetsen met betrekking tot het hoofdeffect van "actiefprobleem-aanpakken" zijn veel positiever. De partiële correlaties geven aan dat naarmate men een meer actieve aanpak in moeilijke situaties/gebeurtenissen op het werk hanteert, men meer tevredenheid en eigen werkwaardering en minder gezondheidsklachten rapporteert. Werkt men daarentegen in een wat (onze) werkaspecten betreft vergelijkbare werksituatie, dan blijft de relatie met gezondheidsklachten en eigen werkwaardering bestaan, maar verdwijnt de samenhang met tevredenheid.

Met betrekking tot de copingstrategie "comforting cognitions" tenslotte worden zeven significante interacties aangetroffen $(19.4 \%)$. De interpretatie van deze interacties geeft aan dat in 
een werksituatie die zich kenmerkt door: complexiteit/moeilikheid, ruimte voor verzorgende/begeleidende activiteiten, een meer patiënt- dan taakgerichte methode van verplegen en verzorgen, feedback/duidelijkheid en door een afdelingshoofd dat grote nadruk legt op zowel de sociaal-emotionele als de instrumentele aspecten, verpleegkundigen die niet of slechts weinig gebruik maken van de copingstrategie "comforting cognitions" positievere (of minder negatievere) reacties op het werk vertonen.

De copingstrategie "comforting cognitions" heeft slechts een select hoofdeffect op de reactievariabelen. Zowel bij de berekening van de partiële correlaties als in de hiërarchische regressie-analyses blijken alleen de correlaties met gezondheidsklachten significant.

Afsluitend kan op grond van onze bevindingen in deze paragraaf geconcludeerd worden dat de variabelen "sociale steun", "actief-probleem-aanpakken" en "palliatieven" in een hoofdeffect invloed uitoefenen op de reacties van verpleegkundigen, al dan niet gecontroleerd voor de invloed van de negen in het onderzoek opgenomen werkaspecten. Dit geldt in mindere mate voor "comforting cognitions" en voor "behoefte aan autonomie". In het algemeen zijn de resultaten met betrekking tot de moderatorfunctie van de individuele/psychosociale kenmerken teleurstellend. Desalniettemin moet rekening gehouden worden met een modererende werking en wel voornamelijk van "sociale ondersteuning" en "comforting cognitions".

NOTEN

1) $P / F c h$ is de overschrijdingskans van de F-waarde verkregen bij de toetsing van de multiple correlatie coëfficiënt na toevoeging van de betreffende predictor aan de vier controle-variabelen (zie ook bijlage 8 ). 


\section{RESULTATEN "SECUNDAIRE ONDERZOEKS- VRAAGSTELLINGEN"}

\subsection{Inleiding}

In dit hoofdstuk komen de resultaten aan de orde betreffende drie onderzoeksvraagstellingen die in feite van secundair belang zijn in het kader van de doelstellingen van dit onderzoek. De relevantie van deze studie ligt immers primair in het achterhalen van oorzaken wan positieve c.q. negatieve reacties van verpleegkundigen op hum werksituatie.

De betekenis van de drie secundaire vragen moet desalniettemin niet worden onderschat. Behandeling van deze vraagstellingen vindt niet alleen plaats omdat het onderzoeksmateriaal ons deze kans biedt, maar ook ter bijdrage aan inzichten die ook in andere onderzoeken reeds aan de orde zijin gesteld.

Achtereenvolgens worden aan de orde gesteld: de onderlinge relaties tussen de reactie-variabelen (6.2), de onderlinge relaties tussen de individuele/psychosociale kenmerken (6.3) en de vergelijking van de beoordelingen van taakkenmerken door respectievelijk verpleegkundigen en het verpleegkundig management (6.4). Afgesloten wordt met een korte samenvatting en conclusies (6.5).

\subsection{De onderlinge samenhang tussen de reactie-variabelen}

De onderhavige vraag naar de intercorrelaties tussen de afhankelijke variabelen (onderzoeksvraagstelling 4) wordt in deze paragraaf volledigheidshalve behandeld in het kader van het al dan niet bevestigen van bevindingen van andere onderzoeken in deze.

Bovendien zal getracht worden aan de hand van het patroon van correlaties na te gaan of er mogelijk sprake is van meerdere niveau's van afhankelijke variabelen, zoals bijwoorbeeld Algera voorstelt (1981) in diens herformulering van het "Job Characteristics Model". Zo wordt onder andere in dit nieuwe model ziekteverzuim rechtstreeks voorspeld uit cen aantal taakkenmerken. De kritische psychologische toestanden van Hackman en Oldhan $(1975,1976)$ (uitgebreid met interne werkmotivatie en betrokkenheid) zijn in een cerste niveau an de afhankelijke kant van het model opgenomen en beïnvloeden als zodanig het tweede niveau afhankelijke variabelen, te weten de tevredenheidsdimensies. Deze satisfactie-variabelen voorspellen op hun beurt wederom het derde niveau, namelijk de gezondheidsklachten.

Uiteraard is het onmogelijk een dergelijke (tijds)wolgorde in de afhankelijke variabelen op grond van correlaties vast te stellen. De causale keten die hiermee gesuggereerd wordt is derhalve als zodanig niet aantoonbaar met correlationeel onderzoek. Uit inspectie van de correlatiematrices kunnen wel indicaties voortvloeien, die eventueel in een vervolgonderzoek met een andere (niet-transversale) design getoetst kunnen worden.

Tabel 6.1 geeft de samenhangen weer tussen de reactie-variabelen onderling op individueel niveau. Evenals in het vorige hoofdstuk is hier gebruik gemaakt van partiële correlaties, gecorrigeerd voor de vier in het onderzoek opgenomen controle-variabelen ("geslacht" ${ }^{\text {" }}$ "functie", "soort betrekking", "jaren werkzaam in het ziekenhuis"). 
Tabel 6.1. Partiele correlaties tussen de reactie-wariabelen onderling op individued niveau $(n=561)$ (bij verzuimfrequente $\mathrm{n}=427$ ) a)

\begin{tabular}{|c|c|c|c|c|}
\hline & 1 & 2 & 3 & 4 \\
\hline $1_{\text {I }}$ tevredenheid & & $-477 *$ & $38 * * *$ & -.10 \\
\hline 2. gezondheidsklachten & & & $-.12 *$ & $.16^{* * *}$ \\
\hline 3. eigen werkwaarderimg & & & & $-12^{*}$ \\
\hline 4. verzuimfrequentie (log) & & & & \\
\hline
\end{tabular}

*** $\mathrm{p} \leq 0.001 ; *$ p $\leq 0.01 ; * 0.05$ (tweezijdig); a) gecorrigeerd voor de effecten van de vier controle-variabelen "gesllacht", "functie", "soort betrekking" en "jaren werkzaam in het ziekenhuis"

Wat opvalt in tabel 6.1 is dat de correlaties die significant blijken te zijn logische samenhangen aangeven. Zo bestaat er een relatief hoge negatieve correlatie tussen tevredenheid en gezondheidsklachten (-.47), hetgeen aansluit bij de bevindingen van Algera (1981) en Wall e.a. (1978). Ook de samenhang tussen tevredenheid en eigen werkwaardering kan redelijk genoemd worden (.38). Onze factor "eigen werkwaardering" bundelt in feite twee van de drie kritische psychologische toestanden van Hackman en Oldham, te weten "ervaren betekenis" en "ervaren verantwoordelijkheid", met "interne werkmotivatie". Wanneer we de gemiddelde correlatie tussen tevredenheidsdimensies en de drie kritische psychologische in de onderzoeken van Wall e.a., Algera en Hackman en Oldham beschouwen, zien we dat deze respectievelijk $0.39,0.37$ en 0.48 zijn, grotendeels overeenkomstig ons verband tussen tevredenheid en eigen werkwaardering. Alhoewel de correlatie tussen eigen werkwaardering en gezondheidsklachten niet hoog is (-.12), is deze wel significant $(\mathrm{p} \leq 0.05)$. Wederom is deze relatie vergelijkbaar met de correlaties aangetroffen door Wall e.a. en Algera tussen gezondheidsdimensies en kritische psychologische toestanden (gemiddeld 0.25 ).

Verzuimfrequentie vertoont significante, alhoewel matige verbanden met gezondheidsklachten (.16) en eigen werkwaardering (-.12).

Tabel 6.2 geeft een overzicht van de partiële correlaties tussen de reactie-variabelen onderling op afdelingsniveau.

Tabel 6.2. Partielle correlaties tussen de reactie-variabelen onderling op afdelingsniveau $(n=36)$ a)

\begin{tabular}{lccc}
\hline & 2 & 3 & 4 \\
\hline 1. tevredenheid & $-.58^{* * * * *}$ & .28 & -.18 \\
2. gezondheidsklachten & & -.03 & .06 \\
3. eigen werkwaardering & & & $-.40^{*}$ \\
4. verzuimfrequentic (log) & & &
\end{tabular}

**** $\mathrm{p} \leq 0.001 ; * * \mathrm{p} \leq 0.01 ; * \mathrm{p} \leq 0.05$ (tweezijdig); a) gecorrigeerd voor de effecten van de vier controle-variabeJen "geslacht", "functie", "soort betrekking" en "jaren werkzaam in het ziekenhuis"

Evenals tot dusver het geval was zijn de correlaties in tabel 6.2 op afdelingsniveau in het algemeen hoger of gelijk dan die op individueel niveau. Opvallend is dat op afdelingsniveau de samenhang tussen gezondheidsklachten en verzuimfrequentie "wegvalt", terwijl de correlatie tussen eigen werkwaardering en verzuimfrequentie op geaggregeerd niveau juist "opkomt". Dit resultaat is 
illustratief voor het verschijnsel dat op individueel niveau individueleverschillen in gezondheid bepalend zijn voor verzuim. Door op afdelingsniveau hiervoor te corrigeren worden verbanden tussen verzaim en niet-medische, werkgerelateerde variabelen (eigen werkwaardering) beter zichtbaar.

Vergelijking van de tabellen 6.1 en 6.2 met respectievelijk tabellen 5.5 en 5.7 biedt zicht op de eventuele aanwezigheid van verschillende niveau's afhankelijke variabelen, zoals dat bijwoorbeeld door Algera wordt voorgesteld. Inspectie van de correlaties zou dan duidelijk aan moeten geven dat bepaalde afhankelijke variabelen sterkere samenhangen vertonen met andere afhankelijke variabelen dan met de werkaspecten, en uiteraard voornamelijk met de taakkenmerken. De verwachting, gebaseerd op de herformulering van het "Job Characteristics. Model" door Algera, dat tevredenheid een sterkere correlatie zal vertonen met eigen werkwaardering (opgebouwd uit onder andere twee van de drie psychologische toestanden) dan rechtstreeks met de werkaspecten wordt niet bevestigd. Op beide aggregatieniveaus heeft tevredenheid substantiële samenhangen met de werkaspecten en in bijzonder met de taakkenmerken "feedback/duidelijkheid" (.61 en .80) en "promotie/groei" (.45 en .51) en de sociaal-emotionele leiderschapsstijl (.57 en .60).

De relatief hoge samenhangen tussen tevredenheid en gezondheidsklachten $(-.47$ en -.58$)$ doen wel vermoeden dat gezondheildsklachten inderdaad te beschouwen zijn als een tweede niveau afhankelijke variabelen na tevredenheid. Echter de rechtstreekse correlaties tussen gezondheidsklachten en de werkaspecten (op individueel niveau varierend van .13 tot .34 en op afdelingsniveau van 45 tot 59) zijn, in tegenstelling tot de bevindingen van Algera, niet dermate laag dat dit een overtuigende onderbouwing van een dergelijke modificatie van het model oplevert.

Verzuimfrequentie tenslotte vertoont op individueel niveau zowel met de andere reactie-variabelen als met de werkaspecten lage verbanden. Op afdelingsniveau doet de correlatie met eigen werkwaardering $(-.40)$ vermoeden dat een negatieve eigen werkwaardering vooraf gaat aan deze verzuimdimensie. Echter verzuimfrequentie heeft relevante correlaties met complexiteit/moeilijkheid (-.51) en taakgerichte (versus patiënt-) verpleging (.48). Resumerend blijken er geen eenduidige indicaties aantoonbaar voor een herformulering van het onderzoeksmodel zoals Algera voorstelt. Bovendien geven de correlaties niet duidelijk aan dat eigen werkwaardering (vergelijkbaar met de psychologische toestanden van Hackman en Oldham, 1975, 1976) vooraf gaat aan de overige reacties van verpleegkundigen.

\subsection{De onderlinge samenhang tussen de individuele/psychosociale kenmerken}

De secundaire onderzoekvraagstelling 5 naar de samenhang tussen de individuele/psychosociale kenmerken onderling wordt in deze paragraaf behandeld met behulp van Product Moment Correlatie Coëfficiënten. In tabel 6.3 wordt een overzicht gegeven van de intercorrelaties. 
Tabel 63. Intercorclaties indiwiduele/psychosociale kenmerken op individueel miveau $(n=561)$

\begin{tabular}{|c|c|c|c|c|}
\hline 1 & 2 & 3 & 4 & 5 \\
\hline 1. soxiale steun & -.05 & $.24^{* * *}$ & $.12^{*}$ & -.03 \\
\hline 2. behoefte an alutonomic & & 07 & $-.10^{*}$ & -04 \\
\hline 3. actief-probleem anpalkken & & & $.29 * * *$ & .09 \\
\hline 4. comforting cognitions & & & & $.44^{* * *}$ \\
\hline 3. palliatieven: & & & & \\
\hline
\end{tabular}

" p $\leq 0.001 ; * * \mathrm{p} \leq 0.01 * * \mathrm{p} \leq 0.05$ (wweezijdig)

Uit tabel 6.3 komen aanwijzingen naar voren die de in de literatuur bestaande veronderstelling bevestigen dat sociale ondersteuning en copingstrategieën onderling samenhangen. Socialle steun vertoont positieve samenhangen met de copingstrategieën "actief-probleem-aanpakken" (.24) en "comforting cognitions" (.12). Alhoewel deze correlaties aan de lage kant zijn, zijn ze wel significant. Over de oorzaak-gevolg relatie tussen beide concepten bestaan in de literatuur tegenstrijdige opvattingen. Sommige auteurs beweren dat sociale steun coping beïnvloedit door probleemoplossend gedrag te bevorderen via bevestiging van de eigen identiteit (Van de Vliert en De Boer, 1984) of via het verlenen van suggesties c.q. assistentie in problematische situaties/gebeurtenissen (Thoits, 1986). Andere auteurs daarentegen gaan ervan uit dat copingstrategieën invloed uitoefenen op sociale steun doordat copingvaardigheden een rol spelen bij het vermogen om steun te mobiliseren en te ontvangen (Van Dam-Baggen, 1989) of doordat de manier waarop personen omgaan met stressvolle omstandigheden andere mensen indicaties verschaft omtrent de bestaande behoefte aan steun (Dunkel-Schetter e.a., 1987).

Uit tabel 6.3 komt verder naar voren dat copingstrategieën onderling gerelateerd zijn; zo hangt "comforting cognitions" significant positief samen met zowel actief-probleem-aanpakken (.29) als met palliatief copinggedrag (.44). Concreet betekent dit dat naarmate iemand meer gebruik maakt van perceptie-gericht gedrag, zoals "comforting cognitions", zij/hij eveneens vaker de actieve en de palliatieve aanpak hanteert. De verschillende copingstrategieën blijken derhalve niet onafhankelijk van elkaar.

Tenslotte wordt duidelijk dat naarmate verpleegkundigen meer behoefte aan autonomie hebben ze minder gebruik maken van coping gericht op verandering van de perceptie van de situatie $(-10)$.

\subsection{Verschillen in scores van het verpleegkundig management en van de verpleegkundigen op de taakkenmerken}

In deze paragraaf zal nader ingegaan worden op de secundaire onderzoeksvraagstelling 6 betreffende verschillen in beoordelingen van taakkenmerken door verpleegkundigen en het verpleegkundig management. De behandeling van deze vraag stelt een traditioneel probleem binnen de taakkenmerkenbenadering aan de orde, namelijk of men bij het meten van taakkenmerken uit moet gaan van beoordelingen van taken door de taakuitvoerder zelf (subjectief) of door een "objectieve" buitenstaander (bijvoorbeeld leidinggevende).

Zoals reeds opgemerkt bij de bespreking van de te hanteren analyses voor de afzonderlijke deelvraagstellingen $(4.8)$, is voor de beantwoording van onderzoeksvraag 6 gebruik gemaakt van 
Pearson Product Moment Correlaties en paarsgewijze t-toetsen. Beide typen analyses zijn uitgevoerd op het aggregatieniveau van de afdeling $(n=36)$, waarbij per taakkenmerk voor elke afdeling dus een gemiddelde score van de verpleegkundigen (v-score) en een gemiddelde score van het verpleegkundig management ( $\mathrm{m}$-score) berekend is.

De correlaties tussen de v-score en de m-score geven aan of het onderlinge patroon van de verschillen in de v- en m-scores over de afdelingen heen verschilt. De hoogte van de correlatie geeft de mate aan van overeenkomst in het beoordelingspatroon.

Eveneens kan de vraag gesteld worden of de verpleegkundigen consequent lager, hoger of gelijk scoren dan het management op de taakkenmerken. Ook al geeft een hoge correlatie tussen de v-score en m-score op een taakkenmerk een hoge mate van overeenkomst aan in het beoordelingspatroon van verpleegkundigen en management over de afdelingen heen, dan is het niet uitgesloten dat de verpleegkundigen consequent (op alle afdelingen) lager of hoger scoren dan het management. Om dit effect na te gaan zijn per taakkenmerk paarsgewijze $\mathrm{t}$-toetsen uitgevoerd, waarbij voor elk paar waarnemingen ( $\mathrm{v}$-score en $\mathrm{m}$-score per afdeling op het betreffende taakkenmerk) het verschil berekend wordt. De nulhypothese die in dit geval getoetst wordt is dat het gemiddelde verschil tussen alle paren $(n=36$ paren $)$ nul is. Een $t$-toets kon in dit geval uitgevoerd worden omdat alle zes takkenmerken niet van een normale verdeling afweken.

Tabel 6.4. Correlaties tussen scores van de verpleegkundigen en scores van het verpleegkundig managenent op de zes taakkenmerken op afdelingsmiveau $(n=36)$

taakkerwwerk

complexiteit/moeilijkkheid

feedback/duidelijkheid

werkdruk

autonomie

promotie/groei

verz./begel. activiteiten.

\section{conrelatie}

$.95^{* * *}$
$.56^{* * *}$
$.50^{* *}$
.28
$.50 * *$
.09

${ }^{* * *} \mathrm{p} \leq 0.001 ;{ }^{* *} \mathrm{p} \leq 0.01 ;{ }^{*} \mathrm{p} \leq 0.05$ (tweezijdig)

Tabel 6.4 geeft voor elk taakkenmerk een overzicht van de correlatie tussen de $v$ - en de m-scores. De taakkenmerken "werkdruk", "promotie/groei", "feedback/duidelijkheid" en "complexiteit/moeilijkheid" vertonen relatief hoge samenhangen tussen de inschatting van de aanwezigheid van deze taakkenmerken door de verpleegkundigen en door het verpleegkundig management (respectievelijk .50, .50, .56 en .95). Voor autonomie en verzorgende/begeleidende activiteiten worden geen significante correlaties tussen beide beoordelingen aangetroffen. Vergelijken we deze bevindingen met die van andere studies kunnen we het volgende vaststellen.

De hoogte van de correlatie tussen de v- en m-scores voor het taakkenmerk "complexiteit/moeilijkheid" komt overeen met de bevindingen in deze door bijvoorbeeld Stone (1976) voor "job scope" (.80), door Stone en Porter (1978) voor "job scope" (.54), door Hackman en Oldham voor de "Motivating Potential Score (MPS)" (.56), door Oldham e.a. (1976) eveneens voor de MPS (.85) en door Gould (1979) voor complexiteit (.48). Zes van de negen items waaruit de factor "complexiteit/moeilijkheid" is opgebouwd zijn direct afkomstig van Algera (1981). Voor deze zes items vond Algera (1983) relatief hoge overeenkomsten tussen beoordelingen van 
taakuitvoerders en van leidinggevenden, varierend wan .51 tot .77 , met een gemiddelde correlatie van .60.

De correlatie tussen beide soorten beoordelingen voor het takkenmerk "feedback/duidelijkheid" is, alhoewel beduidend lager dan die voor "complexiteit/moeilijkheid", relatief hoog (.56). Over het algemeen worden in diverse studies voor het taakkenmerk "feedback" lage samenhangen tussen subjectieve en "objectieve" inschattingen aangetroffen. Zo vermelden Hackman en Lawler (1971) een correlatie van .09, Hackman en Oldham (1975) van .33 (voor "feedback from the job") en .07 (voor "feedback from agents") en Hackman e.a. (1978) van .14. Enkel Stone en Porter (1975) vonden eveneens een relatief hoge samenhang (.58). Voor vier van de negen van Algera afkomstige items die in onze studie het taakkenmerk "feedback/duidelijkheid" meten, werd door Algera (1983) een gemiddelde samenhang gevonden van .51 (varierend van .28 tot $.73)$.

In het algemeen blijkt in dit onderzoek een sterkere samenhang gevonden te worden voor de beoordelingen van feedback/duidelijkheid door de taakuitvoerders zelf en de leidinggevenden dan in andere studies. Een reden hiervoor kan zijn dat onze factor "feedback/duidelijkheid" in tegenstelling tot het taakkenmerk "feedback" in andere studies naast de component "feedback" eveneens een component "duidelijkheid" bevat. Dit maakt de vergelijkbaarheid van onze factor met andere feedback-variabelen niet geheel plausibel. Bovendien meten wij met onze component "feedback" veel eerder de feedback die afkomstig is van anderen (bijvoorbeeld van het afdelingshoofd of de collega's) en voorwaarden (of omstandigheden) die daarvoor noodzakelijk zijn (bijvoorbeeld "de mate waarin het werk gelegenheid biedt tot sociale contacten" en "de ruimte om collega's steun te geven"), terwijl Hackman en Oldham $(1975,1976)$ bijwoorbeeld meer nagaan in hoeverre het uitvoeren van de verschillende arbeidstaken voor de werknemer resulteert in duidelijke informatie over de effectiviteit van zijn taakuitvoering ("feedback from the job itself").

Ook voor het taakkenmerk "werkdruk" wordt een relatief hoge samenhang tussen beide beoordelingen gevonden (.50). In de meeste onderzoeken die opgezet zijn vanuit de traditionele taakkenmerkenbenadering is dit taakkenmerk niet opgenomen, zodat vergelijking met de bevindingen in deze studies niet mogelijk is. De drie items waaruit het taakkenmerk "werkdruk" is opgebouwd zijn echter direct afgeleid van het werk van Algera (1981). Hij vond voor deze drie items een gemiddelde correlatie van .47 (varierend van .34 tot .59). hetgeen aansluit bij ons resultaat (Algera, 1983).

De correlatie tussen de v-en de $\mathrm{m}$-scores voor het taakkenmerk "promotie-groei" is relatief hoog (.50). Ook hier kan geen vergelijking met uitkomsten van andere onderzoeken plaatsvinden, aangezien deze variabele in andere studies niet tot de groep taakkenmerken wordt gerekend. Desalniettemin zou de factor "promotie-groei" te beschouwen kunnen zijn als een afzonderlijk taakkenmerk. In de Twee-factoren theorie van Herzberg e.a. (1959) behoren immers de aspecten "advancement" (bevordering, vooruitgang, promotie) en "growth in competence" (persoonlijke groei en ontwikkeling van vaardigheden) tot de groep "motivators". Dit zijn taakintrinsieke ("content") factoren die voortvloeien uit het werk zelf en verondersteld worden de motivatie c.q satisfactie van taakuitvoerders te vergroten.

De samenhang voor autonomie $(.28)$ is niet sterk genoeg om de significantiegrens te bereiken. Deze bevinding wijkt af van de resultaten die in andere studies met dit taakkenmerk worden geboekt (bij Hackman en Lawler, 1971: .85; bij Hackman en Oldham, 1975: .58; bij Jenkins e.a., 1975: .35; bij Stone en Porter, 1975: .76). Voor de drie items waaruit de factor "autonomie" bestaat vond Algera (1983) een gemiddelde correlatie van .57. In de studie van Hackman e.a. (1978) werd echter eveneens een vrij lage, alhoewel significante, samenhang aangetroffen (.21). 
Voor het specifiek voor de verpleging opgestelde taakkenmerk "verzorgende en begeleidende activiteiten ${ }^{\mathrm{n}}$ tenslotte werd geen overeenstemming gevonden tussen de beoordeling wan de verpleegkundigen en de beoordeling van het verpleegkundig management (.09). Ook dit taakkenmerk is in andere, voornamelijk op de industriële setting gerichte, onderzoeken niet bestudeerd, zodat vergelijking niet kan plaatsvinden.

Tabell 6.5. Vergelijking op afdelingsniveau tussen de scores van tespectievelijk verpleegkundigen en werpleegkundig managenent op de zes taakkenmerken mat behulp van parsgewijtet thetsen $(\mathbf{n}=36)$

\begin{tabular}{llll}
\hline taakkenmerken & gernid.M & gemid.V & $T$ \\
\hline complexiteit/moeilijkheid & 5.48 & 5.57 & 1.53 \\
feedback/duidelijkheid & 5.07 & 4.75 & $5.37^{* * *}$ \\
werkdruk & 4.77 & 4.65 & 1.73 \\
autonomie & 4.68 & 4.63 & 0.58 \\
promotie/groei & 3.83 & 3.70 & 1.18 \\
verz/begel. activiteiten & 5.14 & 5.39 & $3.01^{* *}$
\end{tabular}

"** $\mathrm{p} \leq 0.001 ; * \mathrm{p} \leq 0.01 ;{ }^{*} \mathrm{p} \leq 0.05 ; \mathrm{M}=$ verpleegkundig management; $\mathrm{V}=$ verpleegkundigen

Tabel 6.5 geeft de resultaten van paarsgewijze t-toetsing weer. Voor de taakkenmerken "complexiteit/moeilijkheid", "werkdruk", "autonomie" en "promotie/groei" blijkt geen verschil in gemiddelden aantoonbaar, dat wil zeggen dat verpleegkundigen niet consequent lager of hoger scoren dan het verpleegkundig management. De significante resultaten met betrekking tot de taakkenmerken "feedback/duidelijkheid" en "verzorgende/begeleidende activiteiten" geven aan dat de verpleegkundigen consequent (over alle afdelingen heen) de feedback/duidelijkheid in het werk lager en de omvang van verzorgende/begeleidende activiteiten hoger inschatten dan het verpleegkundig management.

De resultaten met betrekking tot de correlaties en de paarsgewijze t-toetsen (zie tabel 6.4 en $6.5)$ zijn in tabel 6.6 op inzichtelijke wijze samengevat.

Tahel 6.6. Samenwatting resultaten correlaties en paarsgewijze t-toetsen

\begin{tabular}{|c|c|c|}
\hline & $\begin{array}{l}\text { hoge (significante) } \\
\text { correlatie }\end{array}$ & $\begin{array}{l}\text { lage (niet-significante) } \\
\text { correlatie }\end{array}$ \\
\hline $\begin{array}{l}\text { génn verschil } \\
\text { in gemiddelden }\end{array}$ & $\begin{array}{l}\text { complexitteit/moeilh. } \\
\text { werkdruk } \\
\text { promotie/groei }\end{array}$ & autonomie \\
\hline $\begin{array}{l}\text { wél verschil } \\
\text { in gemiddelldem }\end{array}$ & feedback/duidelijkh. & $\begin{array}{l}\text { verzorgende/begeleidende } \\
\text { activiteiten }\end{array}$ \\
\hline
\end{tabular}


In tabel 6.6 zijn de zes taakkenmerken ingedeeld naar de vier mogelijke combinaties van uitkomsten van de correlatie-berekeningen en de $t$-toetsen. Een hoge (= significante) correlatie en geén verschil in gemiddelden in scores van de verpleegkundigen en het verpleegkundig management duidt op een minimale discrepantie in de beoordeling van de taakkenmerken. $D_{\text {it }}$ geldt voor de taakkenmerken "complexiteit/moeilijkheid", "werkdruk" en "promotie/groei".

Bij de drie resterende taakkenmerken is er in bepaald opzicht sprake van verschillen in de beoordelingen van de verpleegkundigen en het verpleegkundig management. Nijhuis (1984) geeft een drietal mogelijke verkJaringen woor discrepanties die gevonden worden tussen verschillende beoordelaars, namelijk:

1) verschil in referentiekader

2) beperktheid van de interne communicatie- en informatiestructuur

3) systematische vertekening.

Trachten we vanuit deze verklaringen de gevonden verschillen in onze studie voor de taakkenmerken "feedback/duidelijkheid", "autonomie" en "verzorgende/begeleidende activiteiten" te beredeneren, komen we tot de volgende conclusies.

Ten aanzien van het taakkenmerk "feedback/duidelijkheid" wordt een hoge correlatie en tevens een verschil tussen de gemiddelden van de v-en de m-scores gevonden. In zo'n geval kan sprake zijn van systematische vertekening, in die zin dat de vragen aangaande feedback/duidelijkheid door de verpleegkundigen anders geïnterpreteerd en beoordeeld zijn dan door het verpleegkundig management; bij de beantwoording van de verschillende items geeft een leidinggevende wellicht eerder een globale indruk in tegenstelling tot de verpleegkundige zelf die op basis van specifieke gebeurtenissen en situaties een oordeel velt. Bovendien kan een dergelijk resultaat volgens Nijhuis veroorzaakt worden door verschillen in referentiekaders van beide groepen beoordelaars. Het is mogelijk dat de leidinggevende een oordeel geeft redenerend (en vergelijkend met) vanuit zijn eigen positie of die van zijn superieuren, terwijl bij de verpleegkundigen veel meer de invloed van collega's de doorslag geeft. Dit laatste komt overeen met de veronderstelling van de "Social Information Processing"-benadering (zie 3.3.4), namelijk dat percepties van taken niet rechtstreeks af te leiden zijn van de objectieve werksituatie, zoals de taakkenmerkenbenadering suggereert, maar eveneens beïnvloed worden door percepties van anderen (bijvoorbeeld collega's).

Een andere vorm van discrepantie doet zich voor bij het taakkenmerk "verzorgende/begeleidende activiteiten". Voor deze variabele wordt een lage correlatie gepaard gaande met een significant verschil in gemiddelden gevonden. Van een derde vorm van discrepantie is sprake bij een lage correlatie en geên verschil in gemiddelden, hetgeen voor het taakkenmerk "autonomie" geldt. Dit laatste impliceert dat er een relatief hoge overeenstemming tussen beide groepen beoordelaars bestaat ten aanzien van de mate waarin verpleegkundigen autonomie hebben, zonder dat gesproken kan worden van een systematisch beoordelingspatroon. Deze beide laatste typen discrepantie zijn volgens Nijhuis bijvoorbeeld te verklaren door gebrekkige kennis van de leidinggevenden over, in ons geval, het werk op de verpleegafdelingen, hetgeen mogelijk te wijten is aan een beperkte interne communicatie- en informatiestructuur.

Resumerend blijken er overeenkomsten aantoonbaar in beoordelingen van taakkenmerken door verpleegkundigen respectievelijk het verpleegkundig management (bijvoorbeeld ten aanzien van complexiteit/moeilijkheid, werkdruk, promotie/groei). Echter zijn er tevens aanwijzingen voor verschillende vormen van discrepantie (bijvoorbeeld ten aanzien van feedback/duidelijkheid, autonomie, verzorgende/begeleidende activiteiten), welke mogelijk verklaarbaar zijn vanuit sociale, organisationele en onderzoekstechnische bronnen. 


\subsection{Samenvatting en conclusies}

In dit hoofdstuk is een drietal secundaire onderzoeksvraagstellingen behandeld. De resultaten aangaande onderzoeksvraag 4 tonen logische samenhangen tussen de reactie-variabelen onderling, die over het algemeen overeenstemmen met in andere studies gevonden correlaties. Inspectie en vergelijking van de onderlinge samenhangen tussen de reactie-variabelen enerzijds en de samenhangen tussen de werkaspecten en de verschillende reactie-variabelen anderzijds geven vooralsnog geen steun aan een herformulering van thet model met meerdere niveau's afhankelijke variabelen, bijvoorbeeld zoals Algera (1981) suggereert of zoals in het "Job Characteristics Model I" van Hackman en Oldham (1975, 1976) wordt gepostuleerd. Voor verscheidene reactie-variabelen worden naast de significante correlaties met andere aflankelijke variabelen eveneens substantiële samenhangen met meerdere werkaspecten gevonden.

Ten aanzien van de onderlinge samenhangen tussen de individuele/psychosociale kenmerken (onderzoeksvraagstelling 5) blijkt dat de psychosociale variabele "sociale ondersteuning" volgens verwachting significante, alhoewel lage, samenhangen vertoont met twee van de drie in het onderzoek opgenomen copingstrategieën, namelijk "actief-probleem-aanpakken" en "comforting cognitions". Voorts blijkt dat de diverse copingstrategieën niet onderling onafhankelijk zijn en dat de variabele "behoefte aan autonomie" negatief gecorreleerd is met de copingstrategie "comforting cognitions".

Ten aanzien van vraagstelling 6 naar de verschillen in taakkenmerken-scores van de verpleegkundigen en van het verpleegkundig management blijkt woor de taakkenmerken "complexiteit/ moeilijkheid", "werkdruk" en "promotie/groei" een relatief hoge overeenstemming aantoonbaar tussen beide groepen beoordelaars ten aanzien van de mate waarin de werksituatie zich door deze drie taakaspecten kenmerkt, waarbij tevens sprake is wan een systematisch beoordelingspatroon. Dit laatste wil zeggen dat aangetoond kon worden dat verpleegkundigen niet consequent lager of hoger scoren dan het verpleegkundig management. Voor de overige drie taakkenmerken "feedback/duidelijkheid", "verzorgende/begeleidende activiteiten" en "autonomie" worden verschillende vormen van discrepantie aangetroffen, die een mogelijke verklaring vinden in sociale bronnen (bijvoorbeeld verschil in referentiekaders), organisationele bronnen (bijvoorbeeld beperktheid van interne communicatie- en informatiestructuur in het ziekenhuis) en onderzoekstechnische bronnen (bijvoorbeeld systematische vertekening). 


\subsection{Inleiding}

In dit laatste hoofdstuk vindt een terugkoppeling plaats naar de aan het onderzoek gestelde doelstellingen en wordt nagegaan in hoeverre aan deze doelstellingen voldaan is. Achtereenvolgens worden de volgende onderwerpen behandeld: de reikwijdte van het onderzoek (7.2), de theoretische implicaties die voortkomen uit de bevindingen van het onderzoek (7.3), de praktische implicaties die aan de resultaten ontleend kunnen worden (7.4) en tenslotte enkele aanbevelingen voor verder onderzoek (7.5).

\subsection{De reikwijdte van het onderzoek}

Zoals met elk onderzoek het geval is, heeft ook de reikwijdte van de onderhavige studie een aantal grenzen. Bespreking van de grenslijnen van bet onderzoek is uiteraard noodzakelijk voor de verdere ontwikkeling van theoretische modellen, specifieke hypothesen en onderzoeksdesigns.

Een eerste opmerking in deze betreft de onderzoeksopzet. Er is gebruik gemaakt van enquêtes waarmee op één moment in de tijd zowel de onafhankelijke als de afhankelijke variabelen gemeten zijn. Een probleem met dit type onderzoek is het hard aantonen van causale verbanden, aangezien aan een belangrijke voorwaarde voor causaliteit, de tijdsvolgorde (oorzaak gaat v66raf aan gevolg), niet voldaan is. Echter door aansluiting te zoeken bij een theorie, die, zij het op beperkte schaal, getoetst is in experimentele en longitudinale onderzoeken, is steun te vinden voor de interpretatie van onze bevindingen. Overigens is de uitvoering van een "echt" gerandomiseerd experiment met voor- en nameting en een controle-groep moeilijk uitvoerbaar in een werksituatie zoals de verpleging, waar men te maken heeft met niet echt onder controle te houden werk van mensen voor mensen.

Een tweede opmerking aangaande de opzet van het onderzoek is dat zowel de onafhankelijke als de afhankelijke variabelen beoordeeld zijn door dezelfde personen. Door verhoogde kans op "common method variance" zouden de relaties tussen de werkaspecten en de reacties overtrokken kunnen zijn. Uit de bespreking van dit probleem in hoofdstuk 3 is echter duidelijk geworden dat uit onderzoeken is gebleken dat taakkenmerken en reacties van taakuitvoerders samenhangen vertonen die onafhankelijk zijn van "common method variance". Desondanks moet er rekening gehouden worden met het voorkomen van methode-variantie.

Een drietal opmerkingen betreft de verwerking van de gegevens. De reductie van het aantal variabelen, zoals beschreven in hoofdstuk 4 , was om aldaar genoemde redenen onvermijdelijk. Echter heeft deze selectie van slechts een beperkt en bewerkbaar aantal variabelen geleid tot verlies aan informatie. Zo is bijvoorbeeld gewerkt met vrij algemene concepten als "arbeidstevredenheid", "eigen werkwaardering" en "gezondheidsklachten". De specifieke samenhangen die de afzonderlijke dimensies van deze variabelen (bijvoorbeeld: tevredenheid met het afdelingshoofd, interne werkmotivatie en geprikkeldheid) met de werkaspecten kunnen vertonen zijn niet nader onderzocht. Hetzelfde geldt voor de groep individuele/psychosociale 
kenmerken. Welowerwogen is ook hier gekozen voor een select aantal variabelen. Dit heeft er onder andere toe geleïd dat het effect van sociale steun, afkomstig van verschillende bronnen (bijwoorbeeld het afdelingshoofd, leerling- en gediplomeerde verpleegkundigen, de partner), op reacties van verpleegkundigen niet afzonderlijk is onderzocht. Dit soort keuzen en de daaraan gekoppelde grensijnen van de studie zijn echter in wetenschappelijk onderzoek onvermijdelijk. Een andere opmerking die de verwerking van de data betreft is dat er geen toetsing van het onderzoeksmodel als geheel heeft plaatsgevonden. Er is een aantal deelanalyses met betrekking tot binnen het model veronderstelde relaties uitgevoerd. Uitspraken over de geldigheid van het model in $z^{\prime} n$ geheel zijn in deze dan ook niet mogelijk. Vanwege het exploratieve karakter van de studie hebben we echter gemeend dat de toegepaste analyse-technieken toereikend zijn.

Een derde bemerking betreffende de dataverwerking heeft te maken met de interne consistentie van het taakkenmerk "verzorgende/begeleidende activiteiten". De betrouwbaarheid van deze variabele blijkt onvoldoende zodat in principe deze factor van verdere berekeningen uitgesloten zou moeten worden. Echter vanwege de ons inziens inhoudelijke relevantie van dit taakkenmerk in de verpleging en de verwachte bijdrage aan de beleving van het werk door verpleegkundigen, zijn uiteindelijk toch somscores berekend en is de relatie nagegaan met de reactie-variabelen. De lage intercorrelaties tussen de drie items waaruit de factor "verzorgende/begeleidende activiteiten" is opgebouwd geeft echter bedenkingen over de inhoud van deze variabele. De factor bestaat in feite uit drie afzonderlijke aspecten van een "gemeenschappelijk" concept dat verwijst naar bepaalde te verrichten verpleegkundige activiteiten (bijvoorbeeld bijstand bij lichaamshygiëne, lichaamshouding en -beweging, voorlichtende, adviserende, instruerende en psychosociale begeleidingsactiviteiten), die alle de persoonlijke omgang met de patiënt centraal stellen. De factor zou dus eveneens benoembaar zijn geweest als "persoonlijke omgang met de patiënt" of "sociale interactie met de patiënt". We hebben er echter voor gekozen de factor te benoemen naar de twee hoogst ladende items om zo de aansluiting te behouden bij de oorspronkelijke bedoeling wan de items.

Tenslotte nog een opmerking die meer van inhoudelijke aard is. Achteraf zou het wellicht goed zijn geweest de rol van een op de verpleegafdeling belangrijke groep, namelijk de artsen, in het onderzoek te hebben betrokken. Waarschijnlijk zal het type arts (bijwoorbeeld leiderschapsstijl van de arts) invloed uitoefenen op de organisatie van de afdeling en op taakkenmerken zoals "werkdruk" en "feedback/duidelijkheid". Als zodanig moet de rol van artsen op een afdeling beschouwd worden als een bepalende factor van de werkaspecten. Voorts is de veronderstelling gerechtvaardigd dat de kwaliteit van de relatie en communicatie met artsen (in)direct van invloed is op reacties van verpleegkundigen op de werksituatie.

\subsection{Theoretische implicaties}

Tot dusver heeft in het merendeel van de studies op het gebied van werk en reacties van verpleegkundigen een theoretische onderbouwing ontbroken. Op grond van een aantal eerder genoemde overwegingen is gekozen voor het "Job Characteristics Model" van Hackman en Oldham $(1975,1976)$ als uitgangspunt van onze studie. De theoretische relevantie van het onderzoek heeft dan ook betrekking op het nagaan van de bruikbaarheid van de taakkenmerkenbenadering ter beschrijving en voorspelling van reacties van verpleegkundigen op de werksituatie.

In hoofdstuk 3 is een aantal knelpunten met betrekking tot het JCM gesignaleerd op grond waarvan, in hoofdstuk 4 , een modificatie van het model is aangebracht, waarbij met name 
aandacht besteed is aan de toepasbaarheid in de verpleging. In deze herformulering van het taakkenmerkenmodel van Hackman en Oldham is een tweetal onafhankelijke variabelen, die kenmerkend zijn voor de organisatie van de verpleegafdeling, aan de taakkenmerken toegevoegd, namelijk leiderschapsstijl wan het afdelingshoofd en het type verpleegsysteem. Daarnaast is in navolging van Wall e.a. (1978) en Algera (1981), als mogelijke reactie op de werksituatie de variabele "gezondheidsklachten" opgenomen en zijn de in het JCM intermediërende psychologische toestanden aan de afhankelijke kant wan het model onder de noemer "eigen werkwaardering" geplaatst.

Een verdere uitbreiding van het model heeft plaatsgevonden in de groep "derde" variabelen. Binnen bet JCM wordt slechts aan de variabele "Growth Need Strength" (groeibehoefte) een modererende rol toegeschreven. In ons onderzoeksmodel is een dergelijke bufferfunctie eveneens aan de variabelen "coping" en "sociale ondersteuning" toegekend. Bovendien is niet alleen het moderator-effect van deze variabelen onderzocht, maar is ook het hoofdeffect op reacties van verpleegkundigen bestudeerd.

\section{DE RELATIE TUSSEN DE WERKASPECTEN EN DE REACTIES VAN VERPLEEGKUNDIGEN}

Zoals uit de vorige paragraaf naar voren is gekomen, is een evaluatie van het model in zijn geheel niet toepasselijk. Daarentegen is een beoordeling van bepaalde; afzonderlijk in het model gepostuleerde relaties wel mogelijk.

In totaal zijn in deze studie negen werkaspecten met behulp van (partiêle) correlaties en stapsgewijze regressie-analyses gerelateerd aan vier reactie-variabelen. De correlaties geven een eerste inzicht in de onderlinge samenhangen, terwijl in de regressie-analyses voor elke reactie-variabele de meest bepalende werkdimensies worden geselecteerd. Bij eventuele unterventies in de verpleegkundige praktijk (zie 7.4) wil men immers veranderingen aanbrengen in die aspecten van het werk waarvan men kan aannemen dat ze de grootste effecten hebben op psychische, psycho-somatische en gedragsmatige reacties van verpleegkundigen. Zowel de correlaties als de regressie-analyses zijn uitgevoerd op individueel- en op afdelingsniveau.

Op afdelingsniveau worden de individuele verschillen in scores op zowel de werkaspecten als op de reactie-variabelen van verpleegkundigen die op dezelfde afdeling werkzaam zijn "uitgemiddeld" "Volgens Hackman en Oldham $(1975,1976)$ zou de perceptie van de kenmerken van de werksituatie voor verpleegkundigen die op dezelfde afdeling werkzaam zijn hetzelfde moeten zijn. De variantie in scores tussen verpleegkundigen van dezelfde afdeling kan dan beschouwd worden als error variantie (zie ook Algera, 1981). Aggregatie op afdelingsniveau leidt dan ook tot een nauwkeurigere schatting van aspecten van het werk op een verpleegafdeling en hun verbanden met de reactie-variabelen. De individuele ruis in die schatting blijft immers buiten beschouwing, waardoor verwacht kan worden dat op afdelingsniveau hogere verbanden aangetroffen worden met de negen werkaspecten.

In het algemeen zijn de vier reactie-variabelen goed woorspelbaar uit de negen werkaspecten. Op afdelingsniveau worden in tegensteiling tot het individueel niveau sterkere verbanden tussen de onafhankelijke en afhankelijke variabelen aangetroffen en wordt in de regressie-analyses een grotere proportie variantie van de reactie-variabelen voorspeld.

Dit geldt in het bijzonder voor de gedragsmatige variabele "verzuimfrequentie", waarvoor op individueel niveau nauwelijks relevante correlaties met de werkaspecten aangetoond zijn. Dit laatste is begrijpelijk aangezien de individuele verschillen in gezondheid op individueel niveau 
dermate bepalend zijn voor (de omvang van) verzuimcijfers dat de invloed van niet-medische, werkgerelateerde factoren nauwelijks te achterhalen is. Een verpleegkundige die bijvoorbeeld te kampen heeft met een chronische aandoening zoals chronische bronchitis zal vaak verzuimen, terwijl zij/hij best tevreden kan zijn met de bestaande werksituatie.

De belangrijkste effecten van de negen werkaspecten samenvattend blijkt dat de taakkenmerken "feedback/duidelijkheid", "autonomie", "promotie/groei" en "verzorgende/begeleidende activiteiten" en het organisatiekenmerk "sociaal-emotioneel leiderschap", conform de verwachting een positieve bijdrage leveren aan reacties van verpleegkundigen. De werkaspecten "werkdruk", "instrumenteel leiderschap" en "taakgerichte verpleging" blijken daarentegen een negatief effect te hebben. De variabele "complexiteit/moeilijkheid" geeft een op het eerste gezicht tegenstrijdig resultaat in die zin dat op individueel niveau complexe en moeilijke werksituaties enerzijds tot een positieve eigen werkwaardering leiden, echter anderzijds gezondheidsklachten bevorderen. Gezien de betreffende items kenmerkt de complexiteit/moeilijkheid van het werk zich voornamelijk door nauwelijks te beinnloedlen en door de aard van het werk opgelegde aspecten zoals: de plotselinge veranderingen in de toestand van de patiënt, de hoeveelheid verschillende hulpmiddelen waarmee gewerkt wordt, de vereiste waakzaamheid, acute opname's, de ernst van mogelijke fouten en vergissingen etcetera. Deze werkaspecten kunnen een uitdaging voor de verpleegkundigen vormen, hetgeen kan leiden tot een positieve eigen werkwaardering. Echter de oncontroleerbaarheid en onvoorspelbaarheid van deze aspecten monden allicht uit in vermeerdering van de psychische en psycho-somatisch gezondheidsklachten.

In de stapsgewijze regressie-analyses blijken in het algemeen die werkaspecten geselecteerd te worden die ook significante (partiële) correlaties met de reactie-variabelen vertonen. Dit geldt zeker op individueel niveau. Op afdelingsniveau voorkomt echter de grote onderlinge samenhang tussen bepaalde predictoren dat in de regressie-vergelijkingen essentiële werkaspecten opgenomen worden. Dit laatste is zeker het geval bij het type verpleegsysteem. Deze variabele onderhoudt namelijk op afdelingsniveau vrij hoge correlaties met werkaspecten als "complexiteit/moeilijkheid", "feedback/duidelijkheid", "autonomie", "promotie/groei" en "instrumenteel leiderschap". Waarschijnlijk betekent dit, dat verscheidene elementen die kenmerkend zijn voor de organisatie van het werk op een verpleegafdeling vertegenwoordigd zijn in enkele van de genoemde werkaspecten, zodat de vrij algemene factor "taakgerichte (versus patiënt-) verpleging" niet als zelfstandig verklarende variabele in de regressie-analyses geselecteerd wordt. Naast het effect van de afzonderlijke leiderschapsdimensies op reacties is eveneens de invloed wan verschillende combinaties leiderschapsstijlen als zodanig onderzocht. Het blijkt dat verpleegkundigen het meest tevreden zijn als het afdelingshoofd veel aandacht besteedt zowel aan de sociaal-enotionele als ook aan de instrumentele aspecten in de stijl van leidinggeven. Ook voor de reactie-variabele "gezondheidsklachten" wordt een lichte tendens in deze richting aangetroffen. Verder blijkt geen van de vier combinaties leiderschapsstijlen enig effect te hebben op de eigen werkwaardering van verpleegkundigen. Voor de bepaling van de verzuimfrequentie tenslotte kan niet eenduidig een optimale combinatie aangewezen worden.

Bestudering van het patroon van onderlinge correlaties tussen de reactie-variabelen en vergelijking met de samenhangen tussen de werkaspecten en de reactie-variabelen heeft aan het licht gebracht, dat voor een intermediërende plaats van de variabele "eigen werkwaardering" (opgebouwd uit "ervaren betekenis", "ervaren verantwoordelijkheid" en "interne werkmotivatie"), zoals het JCM voorstelt, geen duidelijke indicaties uit onze data naar voren komen. Eveneens wordt geen bevestiging gevonden voor meerdere niveau's afhankelijke variabelen zoals Algera 
(1981) suggereert. De reactie-variabelen blijken naast significante onderlinge correlaties essentiële samenhangen te vertonen met diverse werkaspecten.

Om een bijdrage te leveren aan de discussie over het gebruik van subjectieve dan wel "objectieve" taakbeoordelingen, zijn in deze studie de scores op de taakkenmerken van de verpleegkundigen zelf vergeleken met die van het verpleegkundig management.

Wanneer namelijk een redelijke convergentie bestat tussen de beoordelingen van beide groepen, zou dit betekenen dat het probleem van "common method variance", dat verondersteld wordt gepaard te gaan met een wijze van dataverzameling waarbij taakpercepties van werknemers gerelateerd worden aan reacties van dezelfde werknemers, een minder belangrijke rol speelt dan tot dusver werd aangenomen.

Voor de taakkenmerken "complexiteit/moeilijkheid", "werkdruk" en "promotie/groei" wordt inderdaad een hoge mate van overeenkomst in de beoordelingen van beide groepen beoordelaars gevonden. Voor de overige drie taakkenmerken blijken echter discrepanties in de inschattingen te bestaan. Dit betekent dat ófwel de verpleegkundigen over alle afdelingen heen lager scoren dan het verpleegkundig management (in geval van feedback/duidelijkheid), ofwel er geen overeenkomst in het beoordelingspatroon van beide groepen bestaat (in geval van autonomie), ofwel de verpleegkundigen consequent hoger scoren dan het management en geen convergentie in het beoordelingspatroon vertonen (in geval van verzorgende/begeleidende activiteiten). Verklaringen voor deze verschillende vormen van discrepanties zijn reeds eerder gegeven (zie 6.4).

Uit deze bevindingen kan dus afgeleid worden dat, wat betreft de taakkenmerken "feedback/duidelijkheid", "autonomie" en "verzorgende/begeleidende activiteiten", de methode-variantie tot gevolg kan hebben gehad dat de vastgestelde relaties tussen deze drie taakkenmerken en reacties van verpleegkundigen enigermate overtrokken kunnen zijn. Bij de taakkenmerken "complexiteit/moeilijkheid", "werkdruk" en "promotie/groei" zal hier minder gauw sprake van zijn geweest.

\section{DE ROL VAN DE INDIVIDUELE/PSYCHOSOCLALE KENMERKEN}

Met betrekking tot de rol van de individuele/psychosociale variabelen blijken in het algemeen meer aanwijzingen voor een hoofd- dan voor een buffereffect aantoonbaar. Dit zou echter mede bet gevolg kunnen zijn van de toegepaste statistische analyse-technieken. Splitsing in twee subgroepen ter bestudering van de werking van moderatoren kan tot gevolg hebben gehad dat de methode niet krachtig genoeg meer is geweest om bestaande interacties aan te tonen. Ook bij hantering van de 10-procentsgrens als significantie-niveau bleek het buffereffect grotendeels in onvoldoende mate aantoonbaar. De analyses met betrekking tot de hoofdeffecten zijn daarentegen gebaseerd geweest op de hele onderzoeksgroep, zodat significante resultaten eerder gesignaleerd konden worden.

Vooral voor de variabelen "behoefte aan autonomie", "actief-probleem-aanpakken" en zeker voor "palliatieven", geldt dat de resultaten ten aanzien van de moderatorfunctie niet opzienbarend zijn. Voor deze variabelen ligt het aantal interacties in de subgroepregressie-analyses onder of om en nabij kansniveau.

Voor de bufferwerking van het psychosociale kenmerk "sociale steun" en de copingstrategie "comforting cognitions" wordt meer ondersteuning in dit onderzoek aangetroffen. Een beduidend deel van het aantal gevonden significante interacties voor deze variabelen kan beslist niet toegeschreven worden aan kansfluctuaties. 
Concreet zijn de volgende effecten van de vijf individuele/psychosociale kenmerken aangetoond. Voor de variabele "behoefte aan antonomie" zijn de gevonden interacties, alhoewel waarschijnlijk grotendeels door kansfluctuaties bepaald, duidelijk interpreteerbaar en in lijn der verwachting. Verpleegkundigen met veel behoefte aan autonomie reageren positiever naarmate het werk zich kenmerkt door meer feedback/duidelijkheid, meer autonomie, meer patiëntgerichte verpleging en eet geringere mate van instrumenteel leiderschap. Verpleegkundigen met veel behoefte aan autonomie blijken dus de zelfstandigheid en intrinsieke beloningen die gepaard gaan met de aanwezigheild van dexe kenmerken van verpleegkundig werk te waarderen.

Bij controle voor onze negen werkaspecten blijkt de variabele "behoefte aan autonomie" positief gerelateerd aan teyredenheid.

De in deze studie gevonden interacties met betrekking tot het psychosociale kenmerk "sociale steun" bevestigen de veronderstelde bufferhypothese. Sociale steun vanuit de werksituatie kan in meer of mindere mate "bescherming" bieden tegen bepaalde werkaspecten met negatief effect (bijvoorbeeld werkdruk). Bowendien blijkt sociale steun naast deze bufferwerking een rechtstreeks verband te vertonen met positieve reacties van verpleegkundigen op hun werk.

De copingstrategieën "palliatieven" en "actief-probleem-aanpakken" blijken voornamelijk in een hoofdeffect de reacties van verpleegkundigen te beïnvloeden. Echter is uit de partiële correlaties in deze (zie tabel 5.13) naar voren gekomen dat een palliatieve aanpak aan de ene kant gezondheidsklachten oproept en aan de andere kant een positieve eigen werkwaardering bevordert. Volgens Schreurs e.a. (1984) moet men bij de vraag naar de effectiviteit van bepaalde copingstrategieën onderscheid maken tussen effecten op korte en op lange termijn. Copingstrategieën die in eerste instantie een gunstig effect hebben, kunnen op langere termijn geen enkel of zelfs een negatief effect hebben. Vanuit deze stelling redenerend zou de eigen werkwaardering eerder een korte-termijn effect weergeven en gezondheidsklachten meer een lange-termijn reactie in kaart brengen. Vooralsnog blijven dit speculaties zonder echte steun van de onderhavige bevindingen.

Tenslotte is gebleken dat naarmate de werksituatie zich meer kenmerkt door de aanwezigheid van werkaspecten als "complexiteit/moeilijkheid", "aandacht voor verzorgende/begeleidende activiteiten", "patiëntgerichte verpleging", "feedback/duidelijkheid", "sociaal- evenals instrumenteel leiderschap", verpleegkundigen, die niet of slechts zelden "comforting cognitions" als copingstrategie hanteren, positievere (althans minder negatievere) reacties op hun werk vertonen. Confrontatie met genoemde werkaspecten betekent waarschijnlijk dat men zich niet kan veroorloven uitsluitend de perceptie van bepaalde problematische situaties/gebeurtenissen te belinwloeden door geruststelling van de eigen gemoedstoestand. Wellicht biedt deze strategie slechts een tijdelijke oplossing. Men zou daarom vermoeden dat de aanwezigheid van dergelijke werkaspecten een actieve aanpak vergt. De subgroepanalyses met de copingstrategie "actief-probleem-aanpakken ${ }^{\text {th }}$ als moderator kunnen deze veronderstelling overigens niet bevestigen.

"Tevens kon aangetoond worden dat "comforting cognitions" een direct gezondheidsklachten versterkend effect heeft. Verpleegkundigen die bij moeilijkheden zichzelf voorhouden dat het allemaal well mee zal vallen en dat na regen toch weer zonneschijn komt, ervaren dus meer gezondheidsklachten dan verpleegkundigen die dit niet, of in mindere mate doen.

Resumerend is met betrekking tot de rol van de individuele/psycho-sociale kenmerken uit onze gegevens gebleken dat wanneer men veranderingen gaat aanbrengen in bepaalde aspecten van het werk op een verpleegafdeling het bedoelde effect niet voor iedereen in dezelfde mate bereikt zal worden. Met name de mate van sociale steun die men op het werk ervaart en het al dan niet hanteren van de copingstrategie "comforting cognitions" bepalen mede de uiteindelijke reactie van de verpleegkundigen op hun werksituatie. Echter vanwege het exploratieve karakter van 
deze studie en de duidelijke interpreteerbaarheid en consistentie van met name de resultaten aangaande behoefte aan autonomie, zou het al te voorbarig zijn de modererende werking van de variabelen "behoefte aan autonomie", "palliatieven" en "actief-probleem-aanpakken" voorgoed af te schrijven. Te meer daar op dit moment te weinig aandacht besteed is aan de toetsing van de bufferwerking van dergelijke variabelen. Dit geldt zeker voor de gebruikmaking van diverse copingstrategieèn in het algemeen en in het bijzonder binnen de (verpleegkundige) werksituatie.

Binnen de groep individuele/psychosociale kenmerken is eveneens de onderlinge samenhang tussen de variabelen onderzocht. De uit theoretisch oogpunt interessante samenhang tussen sociale ondersteuning en coping kan met onze gegevens niet eenduidig worden onderbouwd. Er worden slechts zwakke verbanden aangetroffen tussen "sociale steun" enerzijds en "actiefprobleem-aanpakken" en "comforting cognitions" anderzijds. Bovendien kunnen we over de causale relatie tussen sociale steun en coping op basis van onze gegevens geen helderheid verschaffen. Volgens Thoits (1986) hebben sociale steun en coping een aantal functies gemeen. Zo zouden situatie-gericht copinggedrag (bijvoorbeeld "actief-probleem-aanpakken") en instrumentele steun beide gericht zijn op de verandering van de stressvolle situatie. Perceptiegerichte coping (bijvoorbeeld "comforting cognitions") en informationele steun zouden daarentegen gericht zijn op de verandering van de betekenis van de stressvolle situatie. Spanning-gericht gedrag (bijwoorbeeld "palliatieven") en emotionele steun tenslotte zouden zich richten op de vermindering van de negatieve gevoelens die gepaard gaan met de blootstelling aan de stressvolle situatie.

In onze studie zijn deze drie toe te kennen functies bij sociale steun echter niet afzonderlijk onderscheiden. Dit zou een verklaring kunnen zijn voor de aangetroffen zwakke samenhangen tussen steun en coping. Tussen sociale steun en palliatieven wordt zelfs geen significante correlatie aangetroffen.

\section{AANKNOPINGSPUNTEN VOOR VOORTGEZET ONDERZOEK}

Om redenen die nader uiteengezet zijn in paragraaf 4.7 is in dit onderzoek uitgegaan van een explorerende benadering. De gevonden verbanden in deze studie kunnen eventueel worden uitgewerkt in de richting van toetsbare voorspellingen voor voortgezet onderzoek. Met het oog hierop zijn de belangrijkste resultaten samengevat. Tabellen 7.1-7.3 presenteren de belangrijkste bevindingen, tevens basis ter hypothesevorming woor verder onderzoek, respectievelijk betreffende de samenhangen tussen de werkaspecten en reacties van verpleegkundigen, betreffende de modererende invloed van de individuele/psychosociale variabelen en betreffende de samenhangen tussen de individuele/psychosociale variabelen en de reactie-variabelen. Enkele algemene opmerkingen kunnen hieraan toegevoegd worden:

1. Het is aanbevelingswaardig in toekomstig onderzoek geen hypothesen te formuleren met betrekking tot de intermediërende rol van bepaalde variabelen, zoals de kritische psychologische toestanden in het model van Hackman en Oldham. Het verdient de voorkeur in toekomstig onderzoek enkel rechtstreekse relaties tussen de werkaspecten en reacties te veronderstellen. Een eventuele herformulering waarin voor de diverse reactie-variabelen zowel rechtstreekse als indirecte (gemedieerd door andere variabelen) relaties met de werkaspecten opgenomen worden, leidt tot een nodeloos ingewikkeld model. Toetsing van een dergelijk model zou in de praktijk moeilijk uitvoerbaar zijn, zeker wanneer men de werking van verschillende individuele/psychosociale variabelen daarbij wil betrekken. Een 
op deze manier te verwachten verbetering in de voorspelling van reacties weegt niet op tegen het verlies aan praktische toepasbaarheid van een dergelijk gecompliceerd model.

2. Gezondheidsklachten zijn goed voorspelbaar gebleken uit de werkaspecten. De verwaarlozing van deze variabele in onderzoeken die zich baseren op het taakkenmerkenmodel van Hackman en Oldham zon derhalve als onterecht beschouwd moeten worden. (zie ook Wall e.a., 1978; Algera, 1981).

3. In de voorspelling van reacties van verpleegkundigen vormen "feedback/duidelijkheid", "werkdruk", "autonomie", "promotie/groei" en "sociaal-emotioneel leiderschap" de meest relevante werkaspecten (zie tabel 7.1). De leiderschapsstijl van het afdelingshoofd vormt derhalve een betekenisvolle uitbreiding van het model van Hackman en Oldham, waarin uitsluitend kenmerken van de taak opgenomen zijn. Men kan zich afvragen of de relevantie van deze leiderschapsstijl in dit verband enkel typerend is voor de verzorgende sector, of eveneens van toepassing kan zijn in andere sectoren zoals de industrie. Instrumenteel leiderschap blijkt enkel in combinatie met sociaal-emotioneel leiderschap van belang (zie 5.2.5).

Werkaspecten die kenmerkend zijn voor de specifieke werksituatie van de verpleging, namelijk "verzorgende en begeleidende activiteiten" en "taakgerichte (versus patiëntgerichte) verpleging", hebben vrijwel geen voorspellende waarde voor reacties van verpleegkundigen.

4. Uitgaande van de bevindingen in deze studie kunnen voorspellingen opgesteld worden aangaande de modererende werking van de individuele/psychosociale kenmerken "sociale steun", "comforting cognitions" en "behoefte aan autonomie". Met betrekking tot de bufferwerking van de variabele "behoefte aan autonomie" blijkt overigens dat, alhoewel het aantal gevonden interacties om en nabij kansniveau ligt, de resultaten duidelijk interpreteerbaar en conform de verwachting zijn.

Tabel 7.2 maakt duidelijk dat verwacht kan worden dat modererende werking van de genoemde drie variabelen zér selectief zal zijn zowel wat betreft de werkaspecten als de reactie-variabelen. Wellicht vormt de invloed van sociale steun hierop een uitzondering omdat deze zich concentreert op relaties tussen de werkaspecten "werkdruk", "autonomie" en "promotie/groei" enerzijds en de reacties "arbeidstevredenheid", "gezondheidsklachten" en "eigen werkwaardering" anderzijds.

5. Ten aanzien van het direct effect van de vijf individuele/psychosociale kenmerken op reacties (zie tabel 7.3) kunnen in toekomstig onderzoek vooral eenduidige hypothesen geformuleerd worden aangaande de positieve invloed van sociale steun en de copingstrategie "actief-probleem-aanpakken" op de tevredenheid, ervaren gezondheid en eigen werkwaardering van verpleegkundigen. Tevens kan men ervan uitgaan dat de omvang van de verzuimfrequentie niet bepaald wordt door de onderzochte individuele/psychosociale variabelen. 
Tabel 7.1. Overzicht van de gevonden samenhangen tussen de werkaspecten en de reactie-variabelen **

Reactie-sariabele:

arbeidstevreden-

heid

gezondheids-

eigen werk-

verzaum-

Werkaspect:

klachten

wairdering

Trequentie

\begin{tabular}{lccc}
\hline compll/moeilijkh. & & + & + \\
feedb./duidelh. & + & - & + \\
werkdruk & - & - & + \\
autonomie & + & & + \\
promotie/groci & + & & + \\
verz/hegel. act. & & - & + \\
soc.-emo. leider & + & + &
\end{tabular}

taak(vs. pat.) verpl

* De gepresenteerde samenhangen resulteren uit de verrichte stapsgewijze multiple regressie-analyses op individueel niveau.

** Verbanden zijn gecorrigeerd voor de controle-variabelen "geslacht", "functie", "soort betrekking" en "jaren werkzaam in het ziekenhuis".

Tabel 72. Overzicht van de gevonden modererende invloed van de indlividuele/psychosociale kenmerken "sociale steun vanuit de werksituatie", "comforting cognitions" en "behoefte aan autonomie" *

$\begin{array}{llll}\text { Reactie-variabele: } & & & \\ \text { arbeidstevreden- } & \text { gezondheids- } & \text { eigen werk- } & \text { verzuim- } \\ \text { heid } & \text { klachten } & \text { waardering } & \text { frequentie }\end{array}$

Werkaspect:

\begin{tabular}{|c|c|c|c|c|}
\hline compl/moeilijkh. & $+(\mathrm{e})$ & & $+\left(a^{* *}\right)$ & \\
\hline feedb/duidelh. & & & & $-(e)(0)$ \\
\hline werkdruk & $-(c)$ & & $+(b)$ & \\
\hline autonomie & $+(c)$ & $-(c)$ & $+(c)$ & $+(g)$ \\
\hline promotie/groei & $+\left(a^{* * *}\right)$ & $-(c)$ & $+(c)$ & \\
\hline verz. begell. act. & $+(\mathrm{c})$ & & & \\
\hline soc-emo. leider & & & & $-(e)$ \\
\hline instrum, leider & $+(g)$ & $+(f)$ & & $+(\mathrm{d})$ \\
\hline taak(vs. pat.) verpl. & & & $-(\mathrm{e})$ & $+(0)$ \\
\hline
\end{tabular}

$a=$ hele groep verpleegkundigen; $b=$ verpleegkundigen met "veel" sociale steun vanuit de werksituatie;

$c=$ verpleegkundigen met "weinig" sociale steun wanuit de werksituatie; $d=$ verpleegkundigen die "weel" gebruik maken van "comforting cognitions"; e = werpleegkundigen die "weïnig" gebruilk maken wan "comforting cognitions"; $f=$ verpleegkundigen die "veel" behoefte hebben aan autonomie; $g=$ verpleegkundligen die "weinig ${ }^{n}$ behoefte hebben aan autonomie.

"Verbanden zijn gecorrigeerd voor de controle-variabelen "geslacht", "functie", "soort betrekking" en "jaren werkzaam in het ziekenhuis".

** Verband is sterker voor verpleegkundigen die "weinig" gebruik maken van "comforting cognitions"

*** Verband is sterker voor verpleegkundigen met "weinig" sociale steun vanuit de werksituatie. 
Tabel 73. Oyerzicht wa de gevonden samenhangen tussen de individuele/psychosociale kenmerken en de reactievariabelen *

\begin{tabular}{|c|c|c|c|c|}
\hline $\begin{array}{l}\text { Indilwiduedlpsycho } \\
\text { soctowal kenmerk: }\end{array}$ & $\begin{array}{l}\text { Reache-variabele: } \\
\text { arbeidilstevreden- } \\
\text { heid }\end{array}$ & $\begin{array}{l}\text { gezondheids- } \\
\text { kachten }\end{array}$ & $\begin{array}{l}\text { Eigen werk } \\
\text { wardering }\end{array}$ & $\begin{array}{l}\text { verzuim } \\
\text { frequentie }\end{array}$ \\
\hline $\begin{array}{l}\text { sociale steun } \\
\text { behoefte aan aut. }\end{array}$ & + & - & + & \\
\hline $\begin{array}{l}\text { act-probl.-aanp. } \\
\text { comf. cogn. }\end{array}$ & + & + & + & \\
\hline palliatieven & & + & + & \\
\hline
\end{tabular}

- Verbanden zijt gecorrigeerd voor de controle-variabelen "geslacht" "functie", "soort betrekking" en "jaren werkzaam in het ziekenhuis".

\subsection{Praktische implicaties}

De praktische implicaties van deze studie bestaan daaruit dat aan de verkregen resultaten richtlijnen te ontlenen zijn voor toekomstig beleid in de verpleging. Wanneer men reacties van verpleegkundigen op hun werk wil verbeteren, dan zijn daarvoor op grond van onze bevindingen een aantal praktische aanbevelingen te formuleren, onder te verdelen naar respectievelijk: - aanbevelingen ten aanzien van het organisationele ontwerp van de verpleegafdeling (7.4.1), - aanbevelingen ten aanzien van doelgerichte opleidings- en bijscholingsprogramma's (7.4.2), - aanbevelingen ten aanzien van selectie- en loopbaanbegeleiding (7.4.3).

\subsubsection{Aanbevelingen ten aanzien van het organisationele ontwerp van de verpleegafdeling}

In het algemeen blijken verpleegkundigen een grote behoefte te hebben aan zekerheid en duidelijkheid met betrekking tot de inhoud van hun werk en hun rol binnen dat werk. De feedback die men ontvangt wan het afdelingshoofd en collega's over de taakuitvoering evenals de duidelijkheid in de taakuitvoering blijken een belangrijke rol te spelen bij de reacties van verpleegkundigen.

Daarnaast kan een aantal andere werkaspecten aangewezen worden die bepalend zijn voor positieve reacties van verpleegkundigen en derhalve voor eventuele interventie in aanmerking komen. Verpleegkundigen zouden een ruime mate van autonomie aangaande werkmethoden en -procedures moeten krijgen toegewezen. Bovendien is gebleken dat gelegenheid voor promotie, vakinhoudelijke groei en persoonlijke ontwikkeling door de verpleegkundigen als positief wordt gewaardeerd. Ditzelfde geldt voor de aanwezigheid van voldoende tijd voor verzorgende en begeleidende activiteiten.

Een relatief hoge werkdruk wordt door de verpleegkundigen als negatief geëvalueerd evenals een overwegend taakgerichte aanpak bij het verplegen en verzorgen van de patiënten.

Complexe/moeilijke werksituaties worden op twee manieren beoordeeld. Dit taakkenmerk in het bijzonder vormt in feite een directe indicatie voor de verrijking van de verpleegkundige taak 
en daaraan gekoppeld de aan het werk toe te kennen moeilijkheidsgraad. Uitwoering van een verrijkte taak wordt verondersteld minder gelegenheid te bieden voor routinematige activiteiten en stelt meer eisen aan de opleiding en ervaring van verpleegkundigen met alle uitdaging voor de verpleegkundigen vandien. Dit blijkt ook uit de positieve samenhang tussen dit taakkenmerk en de eigen werkwaardering. Overigens wordt uit de resultaten betreffende dit taakkenmerk eveneens duidelijk dat complexe/moeilijke werksituaties tot meer gezondheidsklachten leiden. Aangezien de mate van complexiteit van de te verrichten taken op een verpleegafdeling veelal bepaald wordt door de aard van de werkzaamheden, zal verandering niet gemakkelijk zijn te realiseren. Het feit dat men te maken heeft met patiënten, wier algehele toestandsbeeld vaak onvoorspelbaar is en plotseling kan veranderen, zeker op intensieve afdelingen, bepaald in sterke mate de condities waaronder men moet werken. Waar men echter well voor zou kunnen zorgen is dat verpleegkundigen leren omgaan met dergelijke werkomstandigheden en in de opleiding hierop goed voorbereid worden.

De bevinding dat sociaal-emotioneel leiderschap bijdraagt aan de verhoging van arbeidstevredenheid en eigen werkwaardering en aan de vermindering van gezondheidsklachten onderstreept het belang van bevordering door het hoofd van een verpleegafdeling van een open atmosfeer en communicatie onder de verpleegkundigen en van diens aandacht voor het (persoonlijk) welzijn van haar/zijn verpleegkundige staf. Instrumenteel leiderschap daarentegen leidt tot meer gezondheidsklachten. Uitsluitend op grond hiervan concluderen dat een afdelingshoofd in mindere mate structurerend zou moeten optreden is echter voorbarig. De analyse betreffende de optimale combinatie van beide leiderschapsstijlen heeft immers uitgewezen dat afdelingshoofden ter bevordering van positieve reacties van hun staf (in het bijzonder de arbeidstevredenheid en ervaren gezondheid), zowel aandacht moeten besteden aan de sociaal-emotionele als ook aan de meer instrumentele structuurgevende aspecten in hun leidinggeven. Een flexibele opstelling, met voortdurende afstemming van de manier van leidinggeven op de behoefte van de verpleegkundige moet gezien worden als een noodzakelijke, zij het niet gemakkelijk te realiseren, eis die aan leidinggevenden in de verpleging gesteld moet worden.

Een mogelijkheid ter stimulering van bovenstaande werkaspecten biedt zogenaamde verticale werkstructurering door bijvoorbeeld de functionele methode van verplegen te vervangen door een verpleegsysteem waarin patiëntentoewijzing centraal staat. In een dergelijke organisatievorm hebben de verpleegkundigen de mogelijkheid de hen toegewezen patiěnten in hun totaliteit te verzorgen en verplegen en als zodanig deel te nemen aan het totale zorgverleningsproces: het opstellen wan een verpleegkundige diagnose en het plannen, uitvoeren en evalueren van verpleegkundige activiteiten. Hantering van het verpleegkundig proces kan een geschikte leidraad vormen ter realisering van een dergelijke systematische probleemoplossende aanpak van de verschillende werkzaambeden van verpleegkundigen. De voltooiing van een compleet en afgerond geheel betekent in de praktijk een verrijking van de kwaliteit van de verpleegkundige taken, waarbij men meer autonomie, verantwoordelijkheid en de daarmee vaak samengaande aansprakelijkheid krijgt toebedeeld. Als resultaat hiervan worden de kennis en vaardigheden van verpleegkundigen optimaal benut en zijn er voldoende mogelijkheden tot zelfactualisatie in de werksituatie aanwezig. Bovendien bestaat in een patiëntgericht verpleegsysteem de ruimte voor het verrichten van verzorgende en begeleidende activiteiten, aangezien de integrale benadering van de patiënt als somatisch-psychisch-sociale eenheid in dit systeem een grotere kans van slagen heeft dan in de taak-verdelende traditionele functionele organisatie. Eveneens kan verwacht worden dat een betere planning en afstemming van activiteiten op 
de lange termijn leidt tot een afname van de werkdruk. Interrupties, die de werkdruk vaak verhogen, zullen zich minder vaak voordoen, aangezien de verpleegkundige de planning van de bezigheden die te maken hebben met de toegewezen patiënten in eigen handen heeft.

Overigens dient bij overgang naar een patiêntgericht zorgsysteem rekening te worden gehouden met een (tijdelijke) verhoging van de werkdruk (AZG, 1986), hetgeen verklaarbaar is wanneer men bedenkt dat de verpleegkundigen zich een geheel nieuwe aanpak van werken moeten eigen maken. Een goede begeleiding bij het initiëren, invoeren, evalueren en bijstellen van een nieuwe, in casu patiëntgerichte, organisatievorm is noodzakelijk.

Ook een duidelijke taakafbakening en -omschrijving moet gezien worden als een vereiste voor een optimale taakuitvoering. Dit geldt zeker voor intensieve verpleegafdelingen, waar regelmatig medisch-technische handelingen door verpleegkundigen worden verricht die wettelijk tot het terrein van de arts behoren (Dassen, e.a., 1987).

Bovendien kunnen bevordering van duidelijkheid in het werk en daarnaast mogelijkheden voor het geven van feedback aan elkaar verkregen worden door invoering van een regelmatige gestructureerde intervisie. Dit biedt verpleegkundigen de gelegenheid tot het uitwisselen van ervaringen en gevoelens ten aanzien van het afdelingshoofd, de collega's en de patiëntenzorg. Een goed functionerende intervisie, waarin naast inhoudelijke besprekingen ook aandacht besteed wordt aan de psycho-sociale kanten van het werk van verpleegkundigen, kan als geëigend middel ter verbetering van het sociale ondersteuningssysteem op de afdeling worden gezien. Het geven van sociale steun aan elkaar is van groot belang, aangezien uit onze gegevens is gebleken dat dit psychosociale kenmerk in staat is, zowel met een hoofd- als met een buffereffect positieve reacties van verpleegkundigen op hun werksituatie te bevorderen.

Daadwerkelijke promotie- en doorgroeimogelijkheden met daaraan gekoppeld verhoogde salariëring zijn in de verpleging zeer beperkt. Wellicht zal de aandacht meer gericht moeten worden op de vakinhoudelijke groei en persoonlijke ontwikkeling. Het creëren van mogelijkheden tot deskundigheidsbevordering via na- en bijscholing, het bijwonen van congressen en het stimuleren tot bestudering en bespreking van vakliteratuur, zou hiervoor een aanzet kunnen bieden.

\subsubsection{Aanbevelingen ten aanzien van opleidings- en bijscholingsprogramma's}

In het voorafgaande is reeds aan de orde gesteld dat het verbeteren van het sociale ondersteuningssysteem op de afdeling bevorderd kan worden middels regelmatige en gedegen intervisie. Echter een belangrijke randvoorwaarde voor het slagen van deze aanpak is dat verpleegkundigen daadwerkelijk in staat zijn de behoefte aan steun bij collega's te signaleren en op een doeltreffende wijze daarop in te gaan. Deze vaardigheden kunnen ontwikkeld worden binnen de opleiding, respectievelijk na- en bijscholing.

Een ander punt waaraan opleidings- en bijscholingsprogramma's aandacht zouden kunnen besteden is de manier van omgaan met belastende situaties/gebeurtenissen, met andere woorden de te hanteren copingstrategieën. Een palliatieve aanpak van problemen blijkt een rechtstreeks voornamelijk negatief effect te hebben op reacties van verpleegkundigen, terwijl een actieve aanpak daarentegen juist een rechtstreeks positief effect vertoont. De copingstrategie "comforting cognitions" tenslotte beinvloedt de reacties van verpleegkundigen via een hoofdeffect negatief. Bovendien blijkt dat een eventuele interventie in de werksituatie, waarbij de werkaspecten "complexiteit/moeilijkheid", "verzorgende/begeleidende activiteiten" en "feedback/duidelijkheid", versterkt worden, een meer patiëntgericht verpleegsysteern ingevoerd 
wordt en het afdelingshoofd beide aspecten van leidinggeven benadrukt, enkel voor verpleegkundigen met weinig "comforting cognitions" tot het gewenste effect (positievere reactie) zal leiden. In de opleiding zou aan de verpleegkundigen aangeleerd moeten worden dat in hun omgang met stresserende omstandigheden directe actie-mechanismen het meest effectief zijn. Het zoeken van ontspanning of afleiding zal waarschijnlijk slechts op de korte termijn werkzaam zijn en leidt op de langere duur tot gezondheidsklachten en arbeidsontevredenheid. Ook een copingstrategie, uitsluitend gericht op de verandering van perceptie en evaluatie van de bellastende situatie door middel van geruststelling van de eigen gemoedstoestand (bijvoorbeeld "jezelf voorhouden dat het allemaal wel meevalt"), moet als een weinig effectieve en adequate aanpak beschouwd worden. Een stress-management cursus, waarin niet alleen de theoretische achtergrond van het begrip "stress" wordt behandeld, maar eveneens door middel van trainingen een effectieve aanpak kan worden geoefend, verdient derhalve aanbeveling.

In na- en bijscholing van afdelingshoofden in de verpleging zou speciaal aandacht besteed moeten worden aan de juiste afstemming van de sociaal-emotionele en instrumentele aspecten van het leidinggeven.

\subsubsection{Aanbevelingen ten aanzien van selectie- en loopbaanbegeleiding}

Omdat het onderzoek voornamelijk gericht is op de samenhangen tussen werkaspecten en reacties van verpleegkundigen, zijn de aanbevelingen betreffende selectie- en loopbaanbegeleiding beperkt.

Bij selectie van personeel en het uitstippelen van een loopbaan is het belangrijk de juiste criteria te hanteren. Op grond van de bevindingen van deze studie kan een aantal aandachtspunten in deze geformuleerd worden.

Het is gebleken dat de tendens bestaat dat verpleegkundigen met veel behoefte aan autonomie eerder die aspecten van het werk waarderen die kenmerkend zijn voor een "verrijkte" taak (bijvoorbeeld feedback/duidelijkheid, autonomie, patiëntgerichte verpleging) dan verpleegkundigen met weinig behoefte aan autonomie. Ditzelfde geldt voor verpleegkundigen die niet of slechts zelden gebruik maken van "comforting cognitions" als copingstrategie. In een werksituatie waarin bijvoorbeeld een ver doorgevoerde verticale werkstructurering heeft plaatsgevonden, wordt dan ook verwacht dat verpleegkundigen met veel behoefte aan autonomie en een geringe "comforting-cognitions"-aanpak goed zullen functioneren. Het is dus belangrijk in een "verrijkte" werksituatie, waarin andere eisen aan de werknemers gesteld worden dan in een meer gestructureerde situatie, verpleegkundigen te werk te stellen die inderdaad behoefte hebben aan een vrij autonome taakuitvoering en in stresserende omstandigheden niet uitsluitend de perceptie van de situatie trachten te beînvloeden door bijvoorbeeld zichzelf voor te houden dat het allemaal wel mee zal vallen. Bij de selectie van hoofden van een verpleegafdeling moet erop gelet worden dat deze in staat zijn een evenwichtige afstemming van sociaal-emotionele en instrumentele aspecten van het leidinggeven te bereiken.

Met aanbevelingen ten aanzien van selectie- en loopbaanbegeleiding is de nodige voorzichtigheid geboden, vanwege het risico dat positieve aanbevelingen in de praktijk omgekeerd worden gehanteerd als negatieve selectie-criteria. Het is echter juist de specifieke combinatie van persoonlijke eigenschappen, opleiding en ervaring die aangeeft of een individu al dan niet in aanmerking komt voor een bepaalde functie. 


\subsection{Aanbevelingen voor verder onderzoek}

Uit het onderhavige onderzoek is naar voren gekomen dat er in het werk van verpleegkundigen een aantal aspecten aan te wijzen is die samenhangen met reacties zoals arbeidstevredenheid. Daarnaast is gebleken dat een aantal individuele/psychosociale variabelen de uiteindelijke reacties van verpleegkundigen op bun werksituatie mede kunnen bepalen. Een volgende stap zou kunnen zijn dat in een (quasi) experimentele interventie-studie manipulatie van de "oorzakelijke" factoren meer duidelijkheid zou kunnen verschaffen in de causale samenhangen tussen werkaspecten en reacties van verpleegkundigen. Voorts zou in een dergelijke onderzoekslijn de link naar de kwaliteit van zorg gelegd kunnen worden en een afbakening en integratie van de rol van de arts op het onderhavige gebied kunnen plaatsvinden. Op basis van een dergelijk onderzoek kunnen meer concrete en onderbouwde aanbevelingen voor werkstructureringsprojecten in de verpleging gedaan worden.

Gerichte onderzoeken moeten het verschil tussen subjectieve en "objectieve" beoordelingen van werkaspecten aan de orde blijven stellen. De vraag die beantwoord dient te worden luidt als volgt: "Hoe komen taakpercepties tot stand en in hoeverre wijken ze af van "objectieve" beoordelingen van buitenstaanders (bijvoorbeeld leidinggevenden) of van onafhankelijke structurele metingen?" Het meest geschikt hiervoor zijn studies die geheel en al gewijd worden aan de behandeling van deze vraagstelling en niet daarnaast ook nog of voornamelijk gericht zijn op de toetsing van een model zoals het "Job Characteristics Model".

Het afstoten van de moderator-functie in theoretische modellen waarin kenmerken van de werksituatie gerelateerd worden aan de arbeidsbeleving van taakuitvoerders zou al te voorbarig zijn en zou kunnen leiden tot verlies van belangrijke informatie. Aanbevelingswaardig voor onderzoeken naar moderator-effecten is gebruikmaking van grote onderzoekspopulaties, zeker wanneer subgroepanalyses worden toegepast. De zwakke ondersteuning voor de moderatorfunctie kan volgens bijwoorbeeld O'Connor e.a. (1980) te maken hebben met het feit dat onderzoeken naar moderatoren eigenlijk verricht moeten worden over verschillende werkplekken in plaats van binnen één werkplek. Werknemers worden immers voor een bepaalde functie/arbeid geselecteerd op hun persoonlijke eigenschappen en als gevolg daarvan komen personen met dezelfde eigenschappen op vergelijkbare werkplekken terecht. Toekomstig onderzoek naar moderatoren zou dan wel moeten plaatsvinden over zér diverse beroepen en functies, aangezien we in de onderhavige studie al de verpleegkundigen van twee extreme typen verpleegafdelingen hebben betrokken, op grond waarvan verwacht kon worden dat de geënquêteerden zich in voldoende mate onderscheiden op de individuele/psychosociale kenmerken.

Een laatste aanbeveling betreft verder onderzoek naar de relatie tussen sociale ondersteuning en coping. In deze studie zijn lage correlaties gevonden tussen beide variabelen. Te beantwoorden blijft de vraag of hogere verbanden worden gevonden indien ook bij het concept sociale steun de drie aan coping toe te kennen functies (situatie-gericht, perceptie-gericht en spanninggericht) onderscheiden worden. Een tweede aandachtspunt in studies naar de onderlinge samenhang tussen sociale steun en coping tenslotte is het achterhalen van de oorzaak-gevolg relatie en de verschillende processen die daarbij van belang zijn. 


\section{SAMENVATTING}

Het achterhalen van determinanten van arbeidstevredenheid, eigen werkwaardering, gezondheidsklachten en ziekteverzuim van verpleegkundigen moet beschouwd worden als een belangrijke aanzet voor gerichte interventies in de verpleegkundige praktijk. In dit proefschrift wordt verslag uitgebracht van een onderzoek waarin is nagegaan wat het effect is van diverse werkaspecten (taakstructuur, leiderschapsstijl, type verpleegsysteem), individuele en psychosociale kenmerken (preferenties, coping, sociale ondersteuning) op de reacties van verpleegkundigen op hun werksituatie.

In hoofdstuk 1 vindt een korte inleiding op het onderwerp plaats, hetgeen uitmondt in de formulering van de probleemstelling en doelstellingen van de onderhavige studie.

Hoofdstuk 2 bevat een overzicht van onderzoeken naar werk en reacties in de verpleging. Over het algemeen kunnen in deze studies een aantal tekortkomingen gesignaleerd worden, waarvan het ontbreken van een theoretisch kader het meest in het oog springt. Bovendien valt op dat tot nu toe de aandacht van de onderzoeken teveel gericht is geweest op de intensieve verpleegafdelingen. Dit heeft ons doen besluiten zowel intensieve als algemene verpleegafdelingen in het onderzoek te betrekken.

Hoofdstuk 3 geeft een korte schets van het theoretisch uitgangspunt van de studie. Uit voornamelijk in de industrie verrichte onderzoeken blijkt dat taakkenmerken invloed hebben op reacties van werknemers. Op het gebied van onderzoek naar taakontwerp vormt het "Job Characteristics Model (JCM)" van Hackman en Oldham (1975, 1976) de meest toegepaste benadering. Dit model is onderwerp van talloze studies geweest. Naast de positieve eigenschappen van het model zijn eveneens de knelpunten duidelijk geworden. Voor de toepassing van het JCM in de verpleegkundige onderzoekssituatie heeft dan ook een herformulering van het model plaatsgevonden.

In hoofdstuk 4 wordt de modificatie van het JCM gepresenteerd, waarbij aan de taakkenmerken twee organisatiekenmerken zijn toegevoegd, te weten de leiderschapsstijl van het afdelingshoofd en het type verpleegsysteem dat men bij de verpleging en verzorging van de patiënten hanteert. Daarnaast zijn de intermediërende "kritische psychologische toestanden" van Hackman en Oldham aan de afhankelijke kant van het model opgenomen samen met de variabelen "arbeidstevredenheid", "ziekteverzuim" en de nieuw toegevoegde variabele "gezondheidsklachten".

Omdat verwacht kan worden dat niet iedereen op dezelfde wijze reageert op de werksituatie, is in het JCM een moderatorfunctie toegekend aan de variabele "groeibehoefte". Verondersteld wordt namelijk dat mensen met veel behoefte aan groei positiever reageren op werk dat hoog scoort op de vijf centrale taakkenmerken dan mensen met weinig behoefte aan groei. Naast invloed van de "groeibeboefte" (in onze studie inhoudelijk vergelijkbaar met "behoefte aan autonomie") hebben wij tevens het effect van de uit de stressbenadering afkomstige variabelen "sociale ondersteuning" en "coping" bestudeerd. Hierbij is niet alleen een mogelijk moderatoreffect bestudeerd, maar is ook nagegaan of een hoofdeffect-model in aanmerking komt. Vanwege het grote aantal variabelen heeft voorafgaande aan de dataverwerking een weloverwogen reductie van het aantal variabelen plaatsgevonden. Uiteindelijk heeft dit geleid tot een onderzoeksmodel dat is opgebouwd uit negen onafhankelijke variabelen, betreffende werkaspecten (zes taakkenmerken, twee leiderschapsstijlen, het type verpleegsysteem), vier afhan- 
kelijke variabelen, betreffende reacties wan verpleegkundigen (arbeidstewredenheid, eigen werkwaardering, gezondheidsklachten, verzuimfrequentie), vier individuele kenmerken ("behoefte aan autonomie" en de copingstrategieën "actief-probleem-aanpakken", "palliatieven" en "comforting cognitions") en éên psychosociaal kenmerk (sociale ondersteuning vanuit de werksituatie).

Met betrekking tot het aldus verkregen onderzoeksmodel zijn de volgende primaire en secundaire onderzoeksvraagstellingen opgesteld, welke op een exploratieve wijze zijn onderzocht:

\section{PRIMAIRE ONDERZOEKSVRAAGSTELLINGEN:}

1. "Wat is de samenhang tussen de werkaspecten en de reactie-variabelen ?"

2. "Wat is het effect van individuele/psychosociale kenmerken op de reactie-variabelen?"

\section{SECUNDAIRE ONDERZOEKSVRAAGSTELLINGEN:}

3. "Wat is de samenhang tussen de werkaspecten onderling ?"

4. "Wat is de samenhang tussen de reactie-variabelen onderling ?"

5. "Wat is de samenhang tussen de individuele/psychosociale kenmerken onderling ?"

6. "Welke scores vertonen het verpleegkundig management en de verpleegkundigen op de taakkenmerken en wat zijn de verschillen ?"

Ter beantwoording van de vraagstellingen zijn schriftelijke vragenlijsten afgenomen bij 709 verpleegkundigen van 36 intensieve en algemene verpleegafdelingen afkomstig van 16 over Nederland verspreide ziekenhuizen en bij 54 leden van het hoger verpleegkundig kader van deze ziekenhuizen.

In hoofdstuk 5 worden de resultaten met betrekking tot de primaire onderzoeksvraagstellingen behandeld. Alvorens de samenhangen tussen de werkaspecten en de reactie-variabelen te behandelen is in verband met het probleem van de multicollineariteit de vraag naar de onderlinge samenhang tussen de werkaspecten aan de orde gesteld.

Uit de resultaten blijkt dat over het algemeen een toename c.q. uitbreiding van de feedback en duidelijkheid in het werk, de autonomie aangaande werkprocedures en -methoden, mogelijkheden voor promotie, groei en persoonlijke ontwikkeling, gelegenheid in het werk voor verzorgende en begeleidende activiteiten en een afname van de werkdruk en de traditionele taakgerichte wijze van werken positieve reacties van verpleegkundigen kan bevorderen.

De complexiteit van het werk en de aan de taken toe te kennen moeilijkheidsgraad blijken aan de ene kant een uitdaging voor verpleegkundigen te vormen en als zodanig de eigen werkwaardering te bevorderen. Echter aan de andere kant dragen de oncontroleerbaarheid en onvoorspelbaarheid, die waarschijnlijk inherent zijn aan complexe werksituaties, bij aan de vermeerdering van psychische en psychosomatische gezondheidsklachten.

De leiderschapsstijl van het afdelingshoofd blijkt eveneens een belangrijke bijdrage te leveren aan de wijze waarop verpleegkundigen op hun werk reageren. Verpleegkundigen zijn het meest tevreden als hun afdelingshoofd zowel veel aandacht besteedt aan de sociaal-emotionele als aan de meer instrumentele aspecten in haar/zijn stijl van leidinggeven. Van deze dubbelzijdige leiderschapsstijl is eveneens een lichte tendens tot beperking van gezondheidsklachten bij verpleegkundigen aantoonbaar.

Vergelijking van de analyses op individueel en afdelingsniveau brengt aan het licht dat reacties van verpleegkundigen op geaggregeerd niveau beter voorspelbaar zijn uit de werkaspecten. Dit 
geldt vooral voor verzuimfrequentie. Echter doet zich op afdelingsniveau het probleem van de multicollineariteit voor.

Met betrekking tot de rol van de individuele/psychosociale kenmerken in het onderzoeksmodel worden ower het algemeen meer aanwijzingen voor een hoofd- dan woor een buffereffect gevonden. Dit geldt zeker voor de copingstrategieên "actief-probleem-aanpakken" en "palliatieven" die respectievelijk een positieve en voornamelijk negatieve bijdrage leveren aan reacties van verpleegkundigen.

Aan de uit het JCM afkomstige variabele "behoefte aan autonomie" moet op grond van onze gegevens een beperkte rol toegeschreven worden. Alhoewel de gevonden moderator-effecten duidelijk interpreteerbaar en volgens verwachting zijn, kan niet worden uitgesloten dat ze door toevalsfluctuaties zijn bepaald.

Voor de psychosociale variabele "sociale ondersteuning" en de copingstrategie "comforting cognitions" zijn naast directe hoofdeffecten eveneens buffereffecten aangetoond. Sociale steun vanuit de werksituatie (van afdelingshoofd, leerling- en gediplomeerde verpleegkundigen en andere mensen op het werk) blijkt in staat te zijn in meer of mindere mate "bescherming" te bieden tegen bepaalde werkaspecten met negatief effect (bijwoorbeeld werkdruk). Ten aanzien van het gebruik van "comforting cognitions" als copingstrategie is aangetoond dat naarmate in een werksituatie in grotere mate bepaalde werkaspecten (bijvoorbeeld complexiteit/moeilijkheid, patiëntgerichte verpleging) aanwezig zijn, die verpleegkundigen positiever (of minder negatief) op hun werk reageren, die slechts zelden deze strategie toepassen.

Hoofdstuk 6 behandelt de bevindingen ten aanzien van de secundaire onderzoeksvraagstellingen. Op grond van de bestudering van het patroon van onderlinge verbanden tussen de vier reactie-variabelen en vergelijking met de gevonden correlaties tussen de werkaspecten enerzijds en de reactie-variabelen anderzijds kan voor een theoretisch model waarin meerdere niveaus afhankelijke variabelen opgenomen worden geen eenduidige bevestiging gegeven worden.

Uit de behandeling van de vraagstelling aangaande de onderlinge samenhang van de individuele/psychosociale kenmerken blijkt dat deze zwakke correlaties vertonen. De veronderstelde relatie tussen coping en sociale steun kan in deze studie nauwelijks onderbouwd worden. Ten aanzien van de vraagstelling naar de verschillen in beoordelingen van taakkenmerken door verpleegkundigen en het verpleegkundig management blijkt voor de taakkenmerken "complexiteit/moeilijkheid", "werkdruk" en "promotie/groei" een relatief hoge overeenkomst aantoonbaar tussen beide groepen beoordelaars. Voor de overige drie taakkenmerken "feedback/duidelijkheid", "verzorgende/begeleidende activiteiten" en "autonomie" worden echter discrepanties aangetroffen.

In de nabeschouwing van hoofdstuk 7 wordt de reikwijdte van de onderhavige studie besproken. Tevens worden de resultaten met betrekking tot het uit het "Job Characteristics Model" afgeleide onderzoeksmodel nader uitgewerkt. Vervolgens worden een aantal praktische aanbevelingen gedaan ten aanzien van respectievelijk het organisationele ontwerp van de verpleegafdeling, opleidings- en bijscholingsprogramma's en selectie- en loopbaanbegeleiding. Het hoofdstuk wordt uiteindelijk afgesloten met enkele aanbevelingen voor verder onderzoek. 


\section{SUMMARY}

Identifying the determinants of nurses' job satisfaction, job esteem, health complaints and absenteeism must be regarded as a relevant starting point for directional interventions in nursing practice. This dissertation reports on a research in which the effect of various work aspects (structure of the task, leadershipstyle, type of nursing care system), individual and

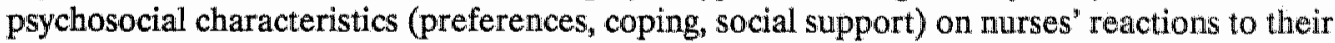
work situation has been examined.

In chapter 1 a short introduction to the subject is given, which leads to the formulation of the problem and goals of the present study.

Chapter 2 contains a review of studies on work and reactions conducted in nursing. On the whole some shortcomings can be signalized in these studies, of which the lacking of a theoretical framework is the most striking. Furthermore it can be noticed that until now research has paid too much attention to intensive care units. Therefore we decided to involve both intensive and general nursing units in the study.

Chapter 3 describes the theoretical starting point of the study. From studies conducted mainly in industry, it appears that job characteristics have influence on reactions of employees. In the field of research on task design the Job Characteristics Model (JCM) of Hackman and Oldham $(1975,1976)$ is the most applied approach. The model has been the subject of countless studies. Besides the positive properties of the model, also the bottlenecks have become clear. For the application of the JCM in the nursing research situation a reformulation of the model has therefore taken place.

In chapter 4 the modification of the JCM is presented, which consists of the adding of two characteristics of the organization to the job characteristics, namely the leadershipstyle of the head of the ward and the type of nursing care system practiced in the nursing and caring for patients. Furthermore the intermediating Hackman and Oldham's critical psychological states are included on the dependent side of the model together with the variables job satisfaction, absenteeism and the newly added variable health complaints.

As it can be expected that not all individuals react to the work situation in the same way, in the JCM a moderator function has been attributed to the variable Growth Need Strength. It is assumed that people with high Growth Need Strength react more positively to work that scores high on the five central job characteristics than people with low need for Growth Need Strength. Besides the influence of Growth Need Strength (in this study it has the same implications as the variable need for autonomy) also the effect of the variables social support and coping, which are derived from the stress approach, has been studied. Not only a possible moderator-effect has been studied, but it has also been checked whether a main effect must be considered.

Previous to the data analysis a well-considered reduction of the number of variables has taken place, because of the large number of variables. Finally this resulted in a research model which consists of nine independent variables concerning work aspects (six task characteristics, two leadershipstyles, the type of nursing care system), four dependent variables concerning reactions of nurses (job satisfaction, job esteem, health complaints, absence frequency) four individual characteristics (need for autonomy and the copingstrategies active-problem-solving, palliative coping and comforting cognitions) and one psychosocial characteristics (social support in the work situation). 
With regard to the model obtained in this way, the following primary and secondary research questions have been drafted, which have been studied in an exploratory way:

\section{PRIMARY RESEARCH QUESTIONS:}

1. "What is the relation between the work aspects and the reaction-wariables?"

2. "What is the effect of the individual/psychosocial characteristics on the reaction-variables?"

SECONDARY RESEARCH QUESTIONS:

3. "What is the relation among the work aspects themselves?"

4. "What is the relation among the reaction-variables themselves?"

5. "What is the relation among the individual/psychosocial characteristics themselves?"

6. "What scores do the nursing management and the nurses have on the task characteristics and what are the differences?"

To answer the research questions questionnaires have been filled up by 709 nurses of 36 intensive and general nursing units from 16 hospitals spread over the Netherlands and by 54 members of the nursing management of these hospitals.

In chapter 5 the results concerning the primary research questions are discussed. Before considering the relations between the work aspects and the reaction-variables, the question of the relation among the work aspects themselves is brought up for discussion, because of the problem of multicollinearity.

The results show that in general an increase c.q. an enlargement of the feedback and clarity in the work, the autonomy concerning working methods and procedures, opportunities for promotion, growth and personal development, opportunities for caring and attending activities and a decrease of the work pressure and the traditional methods of task allocation can stimulate positive reactions of nurses.

The complexity of the work and the degree of difficulty that can be attributed to the tasks appear to be a challenge to the nurses on the one hand and stimulate as such the job esteem. On the other hand, however, the uncontrollability and unpredictability that are probably inherent to complex work situations, contribute to the increase of mental and psychosomatic health complaints.

The leadershipstyle of the head of the ward appears also to make an important contribution to the way in which nurses react to their work. Nurses are most satisfied if their head pays much attention to the social-emotional as well as to the more instrumental aspects in her/his style of leadership. A leadershipstyle with these two aspects also shows a light tendency to a decrease of health complaints of nurses.

Comparison of the analyses on the level of the individual and on the level of the unit shows that nurses' reactions can be better predicted by the work aspects on an aggregated level. This especially applies to absence frequency. On the level of the unit, however, the problem of multicollinearity arises.

Concerning the role of the individual/psychosocial characteristics in the research model, on the whole more indications for a main effect than for a moderating effect are found. This certainly applies to the copingstrategies - active-problem-solving and palliative coping - that respectively make a positive and a mainly negative contribution to nurses' reactions. 
On account of our data a moderate role must be ascribed to the variable need for autonomy that has been taken from the JCM. Although the moderator-effects that are found can be clearly interpreted and are in line with the expectations, the possibility remains that chance fluctuations may account for these results.

Besides direct main effects also moderating effects are found for the psychosocial variable social support and the copingstrategy comforting cognitions. Social support from the work situation (given by the head of the ward, student and licensed nurses and other people at work) appears to be able to offer more or less protection against certain work aspects with a negative effect (for example work pressure). With regard to the use of comforting cognitions as a copingstrategy it is shown that the more some work aspects are present in a work situation (for example complexity/difficulty, patient allocation) the less negative to the work those nurses are that only seldom use this strategy.

Chapter 6 deals with the findings with regard to the secondary research questions, On the strength of the study of the pattern of relations among the four reaction-variables and comparison with the correlations that are found between the work aspects on the one hand and the reaction-variables on the other hand, it is not possible to give a clear confirmation of the theoretical model in which several levels of dependent variables are included.

Furthermore it appears from the treatment of the research question concerning the relation among the individual/psychosocial characteristics themselves that these variables show low intercorrelations. The assumed relation between coping and social support can hardly be supported in this study. With regard to the question of the differences in judgements of task characteristics by nurses and the nursing management it appears that for the taks characteristics: complexity/difficulty, work pressure and promotion/growth a relatively high agreement between both groups of estimators can be proved. However, as to the remaining three task characteristics: feedback/clarity, attending/caring activities and autonomy, discrepancies are found.

In the epilogue of chapter 7 the range of the present study is discussed. Also the results, regarding the research model derived from the Job Characteristics Model are further elaborated. Furthermore some practical recommendations are made concerning the organizational design of the nursing department, education and training programs and selection and career accompaniment, respectively. The chapter is finally concluded with some recommendations for further research. 


\section{LITERATUUR}

Abdel-Halim, A.A., Employee affective responses to organizational stress: moderating effects of job charactestics, Personnel Psychology, 1978, 31, 561-579.

Abdel-Halim, A.A., Social support and managinal effective responses to job stress, Journal of Occupational Behavior, 1982, 3, 281-295.

Abush, R. \& Burkhead, E.J. Job stress in midlife working women: relationships among personality type, job characteristics, and job tension, Journal of Counseling Psychology, $1984,31,36-44$.

Albrecht, T.L., What job stress means for the staff nurse, Nursing Administrative Quarterly, 1982, 7, 1-11.

Aldag, R.J., Barr, S.H. \& Brief, A.P., Measurement of perceived task characteristics, Psychological Bulletin, 1981, 90, 415-431.

Alexander, C.S., Weisman, C.S. \& Chase, G.A.Ch., Evaluating primary nursing in hospitals:

Examination of effects on nursing staff, Medical Care, 1981, 19, 80-89.

Algera, J.A., Kenmerken van werk, Swets \& Zeitlinger, Lisse, 1981.

Algera, J.A., "Objective" and perceived task characteristics as a determinant of reactions by task performers, Journal of Occupational Psychology, 1983, 56, 95-107.

Algera, J.A., Flier, H van der \& Kamp, L.J.Th. van der, Causal modeling of quality of work, in:

Debus, G. en Schroiff, H.W., The psychology of work and organization, Elsevier Science

Publisher, Amsterdam, 1986, 175-182.

Algera, J.A., persoonlijke communicatie, 1987.

Algera, J.A., Taakkenmerken, in: Drenth, P.J.D., Nieuw Handboek Arbeids- en Organisatiepsychologie, Van Loghum Slaterus, Deventer, 1989.

Andriessen, E. \& Drenth, P.J.D., Leiderschap: theorieën en modellen, in: Drenth, P.J.D., Thierry, H., Willems, P.J. \& Wolff, Ch. J. de (red.), Handboek Arbeids- en Organisatiepsychologie, deel I, Van Loghum Slaterus, Deventer, 1983.

Arnold H.A. \& House, J.J., Methodological and substantive extensions to the job characteristics model of motivation, Organizational Behavior and Human Performance, 1980, 25, 161-183.

Arsenault, A. \& Dolan S., The role of personality, occupation and organization in understanding the relationship between job stress, performance and absenteelsm, Journal of Occupational Psychology, 1983, 56, 227-240.

Assen, A van \& Hertog, J.F. den, Werkbeleving en werkstructurering, in: Humanisering van de arbeid, Galan, C. de, Gils, M.R. van \& Strien, P.J. van (red.), Van Gorcum, Assen, 1980, 49-77.

AZG (Academisch Ziekenhuis Groningen), Integrerend verplegen: verslag van een tweejarig experiment in het Academisch Ziekenhuis Groningen, Groningen, 1986.

Bailey, R.N., Walker, D. \& Madsen, N, The design of a stress management program for Stanford intensive care nurses, Journal of Nursing Education, 1980a, 19, 26-29.

Bailey, R.N., Steffen, S.M. \& Grout, J.W., The stress audit: identifying the stressors of ICU nursing, Journal of Nursing Education, 1980b, 19, 15-25.

Barr, A., Absenteeism among hospital nursing staff, Hospital, 1967, 63, 9-12. 
Bastelaer, A. van \& Beers, W. van, Organisatiestress en de personeelfunktionaris, Swets \& Zeitlinger bv., Lisse, 1982.

Bateman, T.S. \& Strasser, $S_{s}$ A Cross-lagged regression test of the relationships between job tension and employee satisfaction, Journal of Applied Psychology, 1983, 68, 439-445.

Bergen, B.J.A.M. van, De verpleegafdeling, traditionele structuur en structuurmogelikheden, Ziekenhuis Research Project, Rapport no. 1, Eundhoven, 1972.

Bergh-Braam, A.HM. van den, Hoofdverpleegkundigen over leven in het ziekenhuis, Spruyt, Van Mantgem \& De Does bv., Leiden 1984

Billings, A.G. \& Moos, R.H., The role of coping responses and social resources in attenuating the stress of life events, Journal of Behavioral Medicine, 1981, 4, 139-157.

Billings, A.G. \& Moos, R.H., Work stress and the stress-buffering rolles of work and family resources, Journal of Occupational Behavior, 1982, 3, 215-232.

Bilodeau, $C_{\text {. }}$, The nurse and her reactions to critical care nursing, Heart and Lung, 1973, 2, 358-363.

Blood, M.R. \& Hulin, C.L., Alienation, environmental characteristics, and worker responses, Journal of Applied Psychology, 1967, 51, 284-290.

Boekholdt, $M_{*}$, Verpleegkundigen en patiẽnten enthousiast over groepsverpleging, Ziekenhuis $11,1981,1016$.

Boumans, N.P.G., Vragenlijstanalyses, resultaten van het vooronderzoek verricht in het kader van de studie "Het werk van verpleegkundigen: een onderzoek naar werkaspecten en hun invloed op verpleegkundigen ${ }^{\prime \prime}$, Intern Rapport, 1986.

Boumans, N.P.G., Resultaten vooronderzoek ICU-project, Vakgroep Medische Psychologie, Rijksuniversiteit Limburg, Maastricht, 1987a.

Boumans, N.P.G. en Landeweerd, J.A., Arbeidswoldoening bij verpleegkundigen, Arbeidsvoldoening, gezondheid-en stressbeleving bij verpleegkundigen in de psychiatrie: een vooronderzoek, Verplleegkunde, 1987b, 1, 4, 234-241.

Boumans, N.P.G., Vragenlijstanalyses, resultaten van het hoofdonderzoek verricht in het kader van de studie "Het werk van verpleegkundigen" een onderzoek naar werkaspecten en hun invloed op verpleegkundigen", Intern Rapport, 1989 .

Brass, D.J., Technology and the structuring of jobs: employee satisfaction, performance, and influence, Organizational Behavior and Human Decision Processes, 1985, 35, 216-240.

Brief, A.P. \& Aldag, R.J., The job characteristics inventory: an examination, Academy of Management Journal, 1978, 21, 659-670.

Brook, P.P., Beyond the Steers and Rhodes Model of Employee Attendance, Academy of Management Review, 1986, 11, 345-361.

Bryson, R.W., Aderman, M, Sampiere, J.M., Rockmore, L\& Matsuda, T, Intensive care nurses: job tension and satisfaction as a function of experience level, Critical Care Medicine, 1985, $13,767-769$.

Burns, H.K., Kirilloff, L.H. \& Close, J.M., Sources of stress and satisfaction in emergency nursing, Journal of Emergency Nursing, 1983, 9, 329-336.

Buunk, A.P. \& Janssen, P., Sociale ondersteuning in de thuissituatie en psychosociale stress op het werk, Gedrag en Gezondheid, 1987, 15, 147-154.

Caldwell, T \& Weiner, M.F., Stresses and coping in ICU-nursing I, a review, General Hospital Psychiatry, 1981, 3, 119-127.

Campion, M.A. \& Thayer, P.W., Development and field evaluation of an interdisciplinary measure of job design, Journal of Applied Psychology, 1985, 70, 29-43. 
Caplan, R.D., Organizational stress and individual strain: a social-psychological study of risk factors in coronary heart disease among administrators, engineers and scientists, Ann Arbor, Institute for Social Research, University of Michigani, 1971.

Caplan, R.D., Cobb, S., French, J.R.P., Harrison, R. van \& Pinneau, S.R., Job demands and worker health: main effects and occupational differences, 1975, HEW (NIOSH); 75-160.

Cassee, E. Th., Gils, M.R. van, \& Philipsen, H., Leiderschap en samenhang van de organisatie, Mens en Onderneming, 1965, 19, 185-196.

Cassee, E. Th., Leidinggeven in ziekenhuizen; een nadere beschouwing, Mens en Onderneming, 1965, 19, 197-206.

Cassee, E. Th., Leiderschap en rolbegrenzing in een ziekenhuisorganisatie, Sociologische Gids, $1967,14,86-100$.

Cassem, N.H. \& Hackett, T.P., Stress on the nurse and therapist in the intensive-care unit and the coronary-care unit, Heart and Lung, 1975, 4, 252-259.

Chadwick-Jones, J.K., Brown, C.A., Nicholson, N. \& Sheppard, C., Absence measures: their reliability and stability in an industrial setting, Personnel Psychology, 1971, 24, 463-470.

Chrisholm, R.F., Kasl, S.V. \& Mueller, L., The effects of social support on nuclear worker responses to the three Mile Island accident, Journal of Occupational Behavior, 1986, 7, 179-193.

Clark, J., Time out? A study of absenteeism among nurses, Roy.Coll.Nursing Nat.Counc., Nurses U.K., London, 1975.

Cobb, S., Social support as a moderator of life stress, Psychosomatic Medicine, 1976, 38, 300-314.

Coghlan, J.A., An analysis of stress in intensive care units in Melbourne, Australian Journal of Advanced Nursing, 1984, 1, 27-32.

Cohen, F. \& Lazarus, R.S., Coping with the stresses of illness, in: Stone, G.C., Cohen, F. en Adler, N.E. (ed.), Health psychology, a handbook, Jossey-Bass, San Francisco, 1979.

Cohen, S \& Wills, T.A., Stress, social support, and the buffering hypothesis, Psychological Bulletin, 1985, 98, 310-357.

Colligan, M.J., Frockt, I.J. \& Tasto, D.L., Frequency of sickness absence and worksite clinic visits among nurses as a function of shift, Applied Ergonomics, 1979, 10, 79-85.

Conrad, K.M., Conrad, K.J. \& Parker, J.E., Job satisfaction among occupational health nurses, Journal of Community Health Nursing, 1985, 2, 161-173.

Constable, J.F. \& Russell, D.W., The effect of social support and the work environment upon burnout among nurses, Journal of Human Stress, 1986, spring, $20-26$.

Cox, T., Stress, coping and problem solving, Work and Stress, 1987, 1, 5-14.

Cronin-Stubbs, D., Job satisfaction and dissatisfaction among new graduate staff nurses, Journal of Nursing Administration, 1977, 7, 44-49.

Cronin-Stubbs, D. \& Rooks, C.A., The stress, social support, and burnout of critical care nurses: the results of research, Heart and Lung, 1985, 14, 31-39.

Cross, D.G. \& Fallon, A., A stressor comparison of four specialty areas, The Australian Journal of Advanced Nursing, 1985, 2, 24-38.

Cross, D.G. \& Kelly, J.G., Stress and coping strategies in hospitals -a comparison of ICU and ward nurses, The Australian Nurses Journal, 1983, 13, 43-46.

Dam-Baggen, R. van, Sociale steun of het belang van de omgeving in een ander perspectief, Gedragstherapie, 1989, 22, 37-51.

Dassen, Th., Topman, H., Theunissen, F. \& Nijhuis, F., De intensive care verpleegkundige en het medisch-technisch handelen, Rijksuniversiteit Limburg, 1987. 
Dassen, Th.; Verplegen in het psychiatrisch centrum: een onderzoek naar taken van psychiatrisch verpleegkundigen, Proefschrift, 1989.

Dear, M.R., Weisman, C.S., Alexander, C.S \& Chase, G.A., The effect of the intensive care nursing role on job satisfaction and turnover, Heart and Lung, 1982, 11, 560-565.

Dewe, P.J., Identifying strategies nurses use to cope with work stress, Journal of Advanced Nursing, 1987, 12, 489-497.

Dijkhuizen, N. van, From stressors to strains: research into their interrelationships, Swets \& Zeitlinger bv., Lisse, 1980.

Dolan, $N_{\text {, }}$, The relationship between burnout and job satisfaction in nurses, Journal of Advanced Nursing, 1987, 12, 3-12.

Dolman, J. \& Visser, A. Ph., Rolspanningen en ontevredenheid in een dubbelrol; de invloed van de werkbegeleiding en de bespreekbaarheid van de rolspanningen van leerling-verpleegkundigen, Gezondheid en Samenleving, 1984, 5, 102-110.

Drenth, P.J.D., Onderzoek in de arbeids- en organisatiepsychologie; Principes en methoden, in: Drenth, P.J.D., Thierry, H., Willems, P.J. \& Wolff, Ch. J. de (red.), Handboek Arbeids- en Organisatiepsychologie, deel I, Van Loghum Slaterus, Deventer, 1983.

Driessen, R., Hartbewaking - problemen wan verpleegkundigen op, centrale bewakingsposten, Literatuurstudie, Technische Hogeschool Eindhoven, afdeling Bedrijfskunde, 1980.

Dunham, R.B., The measurement and dimensionality of job characteristics, Journal of Applied Psychology, 1976, 61, 404-409.

Dunham, R.B., Aldag, R.J. \& Brief, A.P., Dimensionality of Task Design as measured by the Job Diagnostic Survey, Academy of Management Journal, 1977, 20, 209-223.

Dunkel, L.C.S.W. \& Eisendrath, S., Staff reactions in critical care, families in the intensive care unit: their effect on staff, Heart and Lung, 1983, 12, 258-261.

Dunkel-Schetter, C., Folkman, S. \& Lazarus, R.S., Correlates of social support receipt, Journal of Personality and Social Psychology, 1987, 53, 71-80.

Dunnette, M.D. (ed.), Handbook of Industrial Psychology, Rand McNully College, Chicago, 1976.

Durlinger, B., Een onderzoek naar de verpleegkundige zorgkwaliteit, de teamverpleging en de taakinhoud van verpleegkundigen, Afstudeerrapport, Technische Hogeschool Eindhoven, afdeling Bedrijfskunde, Eindhoven, 1981.

Duxbury, M.L., Henly, G.A. \& Armstrong, G.D., Measurement of the murse organizational climate of Neonatal intensive care units, Nursing Research, 1982, 31, 83-88.

Duxbury, M.L., Armstrong, G.D., Drew, D.J. \& Henly, S.J., Headnurse leadership style with staff nurse burnout and job satisfaction in Neonatal intensive care units, Nursing Research, 1984, $33,97-101$.

Eisendrath, S.J. \& Dunkel, J., Psychological issues in intensive care unit staff, Heart and Lung, $1979,8,751-758$.

Everly II, G.S. \& Falcione, R.L., Perceived dimensions of job satisfaction for staff registered nurses, Nursing Research, 1976, 25, 346-348.

Ferris, G.R. \& Gilmore, D.C., The moderating role of work context in job design research: a test of competing models, Academy of Management Journal, 1984, 27, 885-892.

Firth, H., Interpersonal support amongst nurses at work, Journal of Advanced Nursing, 1986, $11,273-282$.

Fleishman, E.A. \& Harris, E.F., Patterns of leadership behavior related to employee grievances and turnover, Personnel Psychology, 1962, 15, 43-56. 
Fleming, R., Baum, A. \& Singer, J.E., Toward an integrative approach to the study of stress, Journal of personality and social psychology, 1984, 46, 939-949.

Floor, R.L., Verloop en ziekteverzuim bij gediplomeerde werpleegkundigen, Technische Hogeschool Eindhoven, afdeling Bedrijfskunde, Z.R.P.-rapport 22, Eindhoven, 1976.

Folkman, S\& Lazarus, R.S., An analysis of coping in a middle-aged community sample, Journal of Health and Social Behavior, 1980, 21, 219-239.

Fried, Y. \& Ferris, G.R., The dimensionality of job characteristics: some neglected issues, Journal of Applied Psychology, 1986, 71, 419-426.

Fried, Y. \& Ferris, G.R., The validity of the job characteristics model: a review and meta-analysis, Personnel Psychology, 1987, 40, 287-322.

Ganster, D.C., The effects of individual differences and objective task scope on task perceptions and satisfaction: a laboratory investigation, Proceedings of the Academy of Management, $1979,39,59-63$.

Gangster, D.C., Fusilier, M.R. \& Mayes, B.T., Role of social support in the experience of stress at work, Journal of Applied Psychology, 1986, 71, 102-110.

Gentry, W.D., Foster, S.B. \& Froehling, S., Psychologic responses to situational stress in intensive and nonintensive nursing, Heart and Lung, 1972, 1, 793-796.

Gentry, D. \& Parkes, W., Psychologic stress in intensive care unit and non-intensive care unit nursing: a review of the last decade, Heart and Lung, 1982, 11, 43-47.

Glick, W.H., Jenkins, G.D. \& Gupta, N., Method versus substance: how strong are underlying relationships between job characteristics and attitudinal outcomes?, Academy of Management Journal, 1986, 29, 441-464.

Gore, S., The effect of social support in moderating the health consequences of unemployment, Journal of Health and Social Behavior, 1978, 19, 157-165.

Gould, S., Age, job complexity, satisfaction and performance, Journal of Vocational Behavior, $1979,14,209-223$.

Graen, G.B., Scandura, T.A. \& Graen, M.R., A field experimental test of the moderating effects of Growth Need Strength on productivity, Journal of Applied Psychology, 1986, 71, 484-491.

Gray, D.E., Job satisfaction among Australian nurses, Human Relations, 1984, 37, 1063-1077.

Gray-Toft, P. \& Anderson, J.G., The nursing stress scale: development of an instrument, Journal of Behavioral Assessment, 1981a, 3, 11-23.

Gray-Toft, P. \& Anderson, J.G., Stress among hospital nursing staff: its causes and effects, Social Science Medicine, 1981b, 15a, 639-647.

Green, S.B., Armenakis, A.A., Marbert, L.D. \& Bedeian, A.G., An evaluation of the response format and scale structure of the Job Diagnostic Survey, Human Relations, 1979, 32, 181-188.

Griffin, R.W., A longitudinal investigation of task characteristics relationships, Academy of Management Journal, 1981, 24, 99-113.

Griffin, R.W., Objective and social sources of information in task redesign: a field experiment, Administrative Science Quarterly, 1983, 28, 184-200.

Grout, J.W., Steffen, S.M. \& Bailey, J.T., The stresses and the satisfiers of the intensive care unit: a survey, Current Issues in critical care, 1981, 3, 35-45.

Gruenfeld, L. \& Kassum, S., Supervisory style and organizational effectiveness in a pediatric hospital, Personnel Psychology, 1973, 26, 531-544.

Gruneberg, M.M., Understandig job satisfaction, McMillan, London, 1979.

Hackman, J.R. \& Lawler III, E.E., Employee reactions to job characteristics, Journal of Applied Psychology Monograph, 1971, 55, 259-286. 
Hackman, J.R \& Oldham, G.R., Development of the Job Diagnostic Survey, Journal of Applied Psychollogy, 1975, 60, 159-170.

Hackman, J.R. \& Oldham, G.R., Motivation through the design of work: test of a theory, Organizational Behavior and Human Performance, 1976, 16, 250-279.

Hackman, J.R., Pearce, J.L. \& Wolfe, J.C., Effects of changes in job characteristics on work attitudes and behaviors: a naturally occuring quasi-experiment, Organizational Behavior and Human Performance, 1978, 21, 289-304.

Hall, B.A. VonEndt, L \& Parker, G., A Framework for measuring satisfaction of nursing staff, Nursing Leadership, 1981, 4, 29-33.

Hammer, T.H. \& Landau, J., Methodological issues in the use of absence data, Journal of Applied Psychology, 1981, 66, 574-581.

Harvey, R.J., Billings, R.S. \& Nilan, K.J., Confirmatory factor analysis of the Job Diagnositic Survey: good news and bad news, Journal of Applied Psychology, 1985, 70, 461-468.

Hay, D. \& Oken D., The psychological stresses of intensive care unit nursing, Psychosomatic Medicine, 1972, 34, 109-118.

Herzberg, F., Mausner, B \& Snyderman, B., The motivation to work, Wiley, New York, 1959.

Heuvel, R.G.M. van den, Teamverpleging: (ont)wikke(le)n en wege, Afstudeerrapport, Tech nische Hogeschool Eindhoven, afdeling Bedrijfskunde, Eindhoven, 1976

Hightower, T., Staff nurses' perceptions of headnurses' leadership style, Nursing Admin istration Quarterly, 1986, Fall, 34-38.

Hinshaw, A.S. \& Atwood, J.R., Anticipated turnover among nursing staff (D.H.H.S., \#R01 NU00908), University Medical Center Corporation Nursing Department, Tucson, Arizona, 1984.

Holsclaw, P.A., Nursing in high emotional risk areas, Nursing Forum, 1965, 4, 36-45.

House, J.S., Work stress and social support, Reading (Mass.), Addison-Wesley, 1981.

House, R.J. \& Baetz, M.L., Leadership: some empirical generalizations and new research directions, in: Staw, B. (ed.), Research in organizational behavior, 1, Greenwich, Con., JAI Press Inc., 1979, 341-423.

Huckabay, L.M.D. \& Jagla, B., Nurses' stress factors in the intensive care unit, Journal of Nursing Administration, 1979, 9, 21-26.

Hulin, C.L. \& Blood, M.R., Job enlargement, individual differences, and worker responses, Psychological Bulletin, 1968, 69, 41-55.

Hulin, C.L., Individual differences and job enrichment: the case against general treatments, in: Steers, R.M. and Porter, L.W. (ed.), Motivation and work behavior, McGraw-Hill, New York, 1975, 425-435.

Idaszak, J.R. \& Drasgow, F., A Revision of the Job Diagnostic Survey: elimination of a measurement artifact, Journal of Applied Psychollogy, 1987, 72, 69-74.

ILO/WHO Committee, Psychosocial factors at work: recognition and control, Report of the Joint ILO/WHO Committee on Occupational Health, Ninth Session, Occupational Safety and Health Series no. 56, Geneva, 18-24 sept., 1984.

Jacobson, S.P., Stressful situations for Neonatal intensive care nurses, The American Journal of Maternal Child Nursing, 1979, 3, 144-150.

Jacobson, S.F, Stresses and coping strategies of Neonatal intensive care unit nurses, Research in Nursing and Health, 1983, 6, 33-40.

Jamal, M., Shift work related to job attitudes, social participation and withdrawal behavior; a study of nurses and industrial workers, Personnel Psychology, 1981, 34, 535-547. 
Jayaratne, S. \& Chess, W.A., The effects of emotional support on perceived job stress and strain, The Journal of Applied Behavioral Science, 1984, 20, 141-153.

Jenkins, G.D., Nadler, D.A. \& Lawler, E.E., Standardized observations: an approach to measuring the nature of jobs, Journal of Applied Psychology, 1975, 60, 171-181.

Jenkins, G.D., Glick, W.H. \& Gupta, N., Job Characteristics and employee responses, Proceedings of the Academy of Management, Proceedings of the Academy of Management, 1983, $43,164-168$.

Johns, G., Attitudinal and nonattitudinal predictors of two forms of absence from work, Organizational Behavior and Human Performance, 1978, 22, 431-444.

Johnson, M.N., Anxiety/stress and the effects on disclosure between nurses and patients, Advanced Nursing Science, 1979, 1, 1-20.

Johnson, M.L., Role ambiguity and job satisfaction of clinical nurses specialists in a cost-conscious environment, Nursing Administration Quarterly, 1986, Fall, 65-71.

Joiner, C., Johnson, V., Chapman, J.B. \& Corkrean, M., The motivating potential in nursing specialties, Journal of Nursing Administrative, 1982, febr., 26-31.

Jong, R. de \& Thierry, H., Functiewaardering, in: Drenth, P.J.D., Thierry, H., Willems, P.J. en Wolff, Ch.J. de (red.), Handboek Arbeids- en Organisatiepsychologie, deel I, Van Loghum Slaterus, Deventer, 1983.

Jöreskog, K.G. \& Sörbom, D., LISREL IV, A general computer program for estimation of linear structural equation systems by maximum likelihood methods, University of Uppsala, 1978.

Kahn, R.L., Wolfe, D.M., Quinn, R.P., Snoek, J.D. \& Rosenthal, R.A., Organizational stress: studies in role conflict and ambiguity, Wiley, New York, 1964.

Karasak, R.A, Triantis, K.P. \& Chaudhry, S.S., Coworker and supervisor support as moderators of associations between task characteristics and mental strain, Journal of Occupational Behavior, 1982, 3, 181-200.

Katerberg, R. jr., Hom, P.W. \& Hulin, C.L., Effects of job complexity on the reactions of part-time employees, Organizational Behavior and Human Performance, 1979, 24, 317332.

Katz, R., Job longevity as a situational factor in job satisfactions, Administrative Science Quarterly, 1978a, 23, 204-223.

Katz, R., The influence of job longevity on employee reactions to task characterictics, Human Relations, 1978b, 31, 703-725.

Kaufman, G.M. \& Beehr, T.A., Interactions between job stressors and social support: some counter intuitive results, Journal of Applied Psychology, 1986, 71, 522-526.

Keane, A., Ducette, J. \& Adler, D.C., Stress in ICU and non-ICU nurses, Nursing Research, $1985,34,231-236$.

Kelly, J.G. \& Cross, D.G., Stress, coping behaviors, and recommendations for intensive care and medical surgical ward registered nurses, Research in Nursing and Health, 1985, 8, 321-328.

Kemp, N.J. \& Cook, J.D., Job longevity and Growth Need Strength as joint moderators of the task design - job satisfaction relationship, Human Relations, 1983, 36, 883-898.

Kiggundu, M.N., An empirical test of the theory of job design using multiple job ratings, Human Relations, 1980, 33, 339-351.

Kiggundu, M.N., Task interdependence and job design: test of a theory, Organizational Behavior and Human Performance, 1983, 31, 145-172. 
Kimmons, G. \& Greenhaus, J.H., Relationship between locus of control and reactions of employees to work characteristics, Psychological Reports, 1976, 39, 815-820.

Kleber, R.J., Stressbenaderingen in de psychologie, Van Loghum Slaterus, Deventer, 1982.

Knoop, R.; Locus of control as moderator between job characteristics and job attitudes, Psychological Reports, 1981, 48, 519-525.

Kobasa, S.C., Hilker, R.R.J. \& Maddi, S.R., Who stays healthy under stress ?, Journal of Occupational Medicine, 1979, 21, 595-598.

Kompier, M.A.J., Arbeid en gezondheid van stadsbuschauffeurs, Eburon, Delft, 1987.

Kosmoski, K.A. \& Calkin, J.D., Critical Care nurses' intent to stay in their positions, Research in Nursing and Health, 1986,9,3-10.

Koumans, A.., Psychiatric consultation in an intensive care unit, JAMA, 1965, 194, 633-637.

Kübler-Ross, E, Lessen voor levenden: gesprekken met stervenden, Ambo, Baarn, 1978.

Kulik, C.T., Oldham, G.R. \& Langner, P.H., Measurement of job characteristics: comparison of the original and the revised Job Diagnostic Survey, Journal of Applied Psychology, 1988, 73, $462-466$.

Landeweerd, J.A. \& Boumans, N.P.G., Work satisfaction, health, and stress: a study of Dutch nurses, Work and Stress, 1988a, 2, 17-26.

Landeweerd, J.A.\& Boumans, N.P.G., Nurses' work satisfaction and feelings of health and stress in three psychiatric departments, International Journal of Nursing Studies, 1988b, 25, 225-234.

LaRocco, J.M., House, J.S. \& French, J.R.P., Social support, occupational stress and health, Journal of Health and Social Behavior, 1980, 21, 202-218.

Larson, E., Lee, P.C, Brown, M.A. \& Shorr, J., Job satisfaction: assumptions and complexities (questionnaire research), Journal of Nursing Administrative, 1984, 14, 31-38.

Larson, E.W. \& Fukami, C.V., Research notes, employee absenteeism: the role of ease of movement, Academy of Management Journal, 1985, 28, 464-471.

Leatt, P. \& Schneck, R., Differences in stress perceived by head nurses across nursing specialties in hospitals, Journal of Advanced Nursing, 1980, 5, 31-46.

Lemler, S.F. \& Leach, A.K., The effect of job satisfaction on retention, Nursing Management, $1986,17,66-68$.

Leppänen, A., Measurement of work characteristics by Questionnaire methods, Symposium: Psychological aspects of the Technological and Organizational Change in Work, 24 oct., 1985, 79-97, edited by Norros, L. en Vartiainen, M..

Likert, R., New patterns of management, McGraw-Hill, New York, 1961.

Loher, B.T., Noe, R.A. Moeller, N.L. \& Fitzgerald, M.P., A meta- analysis of the relation of job characteristics to job satisfaction, Journal of Applied Psychology, 1985, 70, 280-289.

Maloney, J.P. \& Col, Lt. Job Stress and its consequences on a group of intensive care and non-intensive care nurses, Advances in Nursing Science, 1982, Jan., 31-41.

Maloney, J.P. \& Bartz, C., Stress-tolerant people: intensive care nurses compared with non-intensive care nurses, Heart and Lung, 1983, 12, 389-394.

Mann, J.K., Nursing Leadership in the Critical Care setting, Nursing Clinics of North America, $1978,13,131-138$.

Marcelissen, F., Gangmakers van het stressproces: de rol van type-A gedrag en sociale ondersteuning bij het stressproces in de werksituatie, Nederlands Instituut voor Praeventieve Gezondheidszorg TNO, 1987.

Maslach, Chr. \& Jackson, S.E., The measurement of experienced burnout, Journal of Occupational Behavior, 1981, 2, 99-113. 
Maslow, A.H., Motivation and personality, Harper and Row, New York, 1954.

McCormick, E.J. \& Ilgen, D.R., Industrial Psychology, Englewood Cliffs: Prentice-Halls London, 1980.

McCraine, E.W., Lambert, V.A. \& Lambert, C.E., Work stress, hardiness, and burnout among hospital staff nurses, Nursing Research, $1987,36,374-378$.

Menzies, I.E.P., Nurses under stress, International Nursing Review, 1960, 7, 9-16.

Mercx, J.M., Groepsverpleging en groepsverpleging: een organisatiekundige analyse en klassificatie, Tijdschrift voor Ziekenwerpleging, $1975 \mathrm{a}, 28,181-187$.

Mercx, J.M., Teamverpleging, betere verpleging, Ziekenhuis 5, 1975b, 342-6.

Munro, B.H., Job satisfaction among recent graduates of schools of nursing, Nursing Research, $1983,32,350-355$.

Munson, F. \& Clinton, J., Defining Nursing Assignment Patterns; Nursing Research, 1979, 28, 243-249.

Murray, M., Role conflüct and intention to leave nursing, Journal of Advanced Nursing, 1983, 8, 29-31.

Nichols, K.A., Springford, V. \& Searle, J., An investigation of distress and discontent in various types of nursing, Journal of Advanced Nursing, 1981, 6, 311-318.

Nijhuis, F., Beoordelingen van organisatiekenmerken; een sociaal gezondheidkundige studie naar organisatiekenmerken en ziekteverzuim, Dissertatie, 1984 .

Nijhuis, F., Soeters, J., Schröer, K. \& Philipsen, H., Twee onderzoeksmethoden bij studie van arbeid en ziekteverzuim, Tijdschrift voor Sociale Gezondheidszorg, 1985, 63, 355-361.

Norbeck, J.S., Types and sources of social support for managing job stress in critical care nursing, Nursing Research, 1985a, 34, 225-230.

Norbeck, J.S., Perceived job stress, job satisfaction, and psychological symptoms in critical care nursing, Research in Nursing and Health, $1985 \mathrm{~b}, 8,253-259$.

Numerof, R.E., \& Abrams, M.N., Sources of stress among nurses: an empirical investigation, Journal of Human Stress, 1984, 10, 88-100.

NZI (Nationaal Ziekenhuis Instituut), Instellingen van Intramurale Gezondheidszorg, Algemene Ziekenhuizen, staat 1: basisgegevens 1-1-1985, Utrecht, 1985.

NZR (Nationale Ziekenhuisraad), Experiment teamverpleging: resultaten van een onderzoek, Utrecht, 1979.

O'Brien, G.E., Evaluation of the job characteristics theory of work attitudes and performance, Australian Journal of Psychology, 1982, 34,383-401.

O'Connor, E.J., Rudolf, C.J. \& Peters, L.H., Individual differences and job design reconsidem red: where do we go from here?. Academy of Management Review, 1980, 5, 249-254.

Olham, G.R., Job characteristics and internal motivation: the moderating effect of interpersonal and individuall variables, Human Relations, 1976, 29, 559-569.

Oldham, G.R., Hackman, J.R. \& Pearce, J.L., Conditions under which employees respond positively to enriched work, Journal of Applied Psychology, 1976, 61, 395-403.

O'Reilly, C.A. \& Caldwell, D.F., Informational influence as a determinant of perceived task characteristics and job satisfaction, Journal of Applied Psychollogy, 1979, 64, 157-165.

O'Reilly, C.A., Personality job fit: implications for individual attitudes and performance, Organizational Behavior and Human Performance, 1977, 18, 36-46.

Orpen, $C_{*}$, The effects of job enrichment on employee satisfaction, motivation, involvement, and performance: a field experiment, Human Relations, 1979, 32, 189-217.

Oskins, S.L., Identification of situational stressors and coping methods by intensive care nurses, Heart and Lung, 1979, 8, 957-960. 
Ott, M., Klompe, A., Houweling, $\mathrm{J}$. \& Arnold, B., Mannen en vrouwen in de verpleging, Vakgroep Arbeids- en OrganisatiePsychologie, Universiteit van Amsterdam, Amsterdam, 1983.

Parkes, KR., Stressful episodes reported by first-year student nurses: a descriptive account, Social Science Medicine, 1985, 20, 945-953.

Pearlin, L.I. \& Schooler, C., The structure of coping, Journal of Health and Social Behavior, $1978,19,2-21$.

Pearlin, L.L., Lieberman, M.A, Menaghan, E.G. \& Mullan, J.T., The stress process, Journal of Health and Social Behavior, 1981, 22, 337-356.

Peiro, J.M., Zurriage, R. \& Melia, J., Moderating effects of role-set's social support on role stress-strain relationships among hospital nurses and doctors, Paper presented to the Benefits of Psychology Conference, First European Conference on Professional Psychology, Lausanne, Switzerland, sept. 10-12, 1986.

Philipsen, H., Het meten van leiderschap, Mens en Onderneming, 1965, 19, 153-171.

Philipsen, H., Afwezigheid wegens ziekte, Proefschrift, Wolters- Noordhoff, Groningen, 1969.

Philipsen, H. \& Cassee, E. Th., Verschillen in de wijze van leidinggeven tussen drie typen organisaties, Mens en Onderneming, 1965, 19, 172-184.

Pierce, J.L. \& Dunham, R.B., Task design: a literature review, Academy of Management Review, 1976, 4, 83-97.

Pierce, J.L. \& Dunham, R.B., The measurement of perceived job characteristics: the Job Diagnostic Survey versus the Job Characteristics Inventory, Academy of Management Journal, 1978, 21, 123-128.

Pincus, J.D., Communication: key contributor to effectiveness- the research, Journal of Nursing Administrative, 1986, 16, 19-25.

Pinneau, S.R., Effects of social support on psychological and physiological strains, Ann Arbor, ISR, Michigan, 1975.

Pokorney, J.J., Gilmore, D.C. \& Beehr, T.A., Job Diagnostic Survey dimensions: moderating effect of growth needs and correspondence with dimensions of the Job Rating Form, Organizational Behavior and Human Performance, 1980, 26, $222-237$.

Porter, L.W. \& Lawler, E.E., Managerial attitudes and performance, Irwin, Homewood, Illinois, 1968.

Pryer, M.W.\& Distefano, M.K., Perceptions of leadership behavior, job satisfaction, and internal - external control across three nursing levels, Nursing Research, 1971, 20, 534-537.

Reiche, H.M.J.K.I., Stress aan het werk: over de effecten van de persoonlijkheid en sociale ondersteuning op strains, Swets \& Zeitlinger bv., Lisse, 1982.

Reiche, H.M.J.K.I. \& Dijkhuizen, N. van, Vragenlijst Organisatie Stress (VOS): handleiding voor testafname, Stress Research Group Nijmegen, Katholieke Universiteit Nijmegen, publicatie no. $23,1979$.

Roberts, K.H. \& Glick, W., The job characteristics approach to task design: a critical review, journal of Applied Psychology, 1981, 66, 193-217.

Robey, D., Task design, work values, and worker responses: an experimental test, Organizational Behavior and Human Performance, 1974, 12, 264-273.

Roe, R.A., Persoonskenmerken, in: Drenth, P.J.D., Thierry, H., Willems, P.J. \& Wolff, Ch. J. de (red.), Handboek Arbeids- en Organisatiepsychologie, deel I, Van Loghum Slaterus, Deventer, 1983.

Roelens, A.I., Stress en burnout bij verpleegkundigen in algemene ziekenhuizen, Verpleegkunde, $1986,1,170-180$. 
Rosse, J.G. \& Miller, H.E., Relationship between absenteeism and other ermployee behaviors, in: Goodman, P.S. \& Atkin, R.S. (ed.), Absenteeism, Jossey-Bass, San Francisco, 1984, 194-228.

Salancik, G.R. \& Pfeffer, J., An examination of need-satisfaction models of job attitudes, Administrative Science Quarterly, 1977, 22, 427-456.

Sanger, E., Richardson, J. \& Larson, E., What satisfies nurses enough to keep them ? (research), Nursing Management, 1985, 16, 43-46.

Schoonbeek, A, Reacties van verpleegkundigen op hun werk en de relatie hiervan met persoons- en afdelingsgebonden kenmerken, Doctoraal scriptie, Vakgroep Verplegingswetenschap, Rijksuniversiteit Limburg, Maastricht, 1987.

Schreurs, P.J.G., Tellegen, B. \& Willige, G. van de, Gezondheid, stress, coping: de ontwikkeling van de Utrechtse Copinglijst, Gedrag, Tijdschrift voor Psychologie, 1984, 12, 101-115.

Schreurs, P.J.G., Persoonskenmerken en essentiële hypertensie, Dissertatie, 1987.

Schröer, C., Soeters, J. Custers, T., Nijhuis, F. \& Philipsen, H, Werk en ziekte: een onderzoek naar arbeidssituatie, gezondheid en afwezigheid wegens ziekte bij werknemers van 51 organisaties in Zuid-Limburg, Rijksuniversiteit Limburg, 1982

Schwab, D.P \& Cummings, L.L., A theoretical analysis of the impact of task scope on employee performance, Academy of Management Review, 1976, 1, 23-35.

Scheffe, H., The analysis of variance, Wiley, New York, 1959.

Sellick, K.J., Russell, S. \& Beckmann, J.L., Primary Nursing: an evaluation of its effects on patient perception of care and staff satisfaction, International Journal of Nursing Studies, $1983,20,265-273$.

Shaw, J.B., An information-processing approach to the study of job design, Academy of Management Review, 1980, 5, 41-48.

Shukla, R.K. \& Turner III, W.E., Patients perception of care under Primary and Team nursing, Research in Nursing and Health, 1984, 7, 93-99.

Siegel, A.L., Antecedent determinants and consequences of job involvement, Michigan State University, 1971.

Siegel, A.L. \& Ruh, R.A., Job involvement, participation in decision making, personal background, and job behavior, Organizational Behavior and Human Performance, 1973, 9, 318-327.

Simpson, K., Job Satisfaction or dissatisfaction reported by registered nurses, Nursing Administrative Quarterly, 1985, 9, 64-73.

Sims, H.P., Szilagyi, A.D. \& Keller, R.T., The measurement of job characteristics, Academy of Management Journal, 1976, 19, 195-212.

Smith, H.L. \& Mitry, N.W., Nursing leadership: a buffering perspective, Nursing Administrative Quarterly, 1984, spring, 43-52.

Smulders, P.G.W., Comments on employee absence/attendance as a dependent variable in organizational research, Journal of Applied Psychology, 1980, 65, 368-371.

Smulders, P.G.W., Bedrijfskenmerken en ziekteverzuim in de jaren zestig en tachtig: een vergelijkende studie, Dissertatie, Nederlands Instituut voor Praeventieve Gezondheidszorg TNO, publicatie no. 84014, 1984.

Smulders, P.G.W., Bragt, P.C, Grinten, M.P. van der \& Oversloot, J.S., Arbeidssituaties en bedrijfsgezondheidszorg in ziekenhuizen, Literatuurstudie, Directoraat-Generaal van de Arbeid door het Nederlandse Instituut voor Praeventieve Gezondheidszorg TNO en het Medisch Biologisch Laboratorium TNO 1985. 
Spector, P.E., Higher-order need strength as a moderator of the job scope-employee outcome relationship: a meta-analysis, Journal of Occupational Psychology, 1985, 58, 119-127.

Steers, R.M. \& Braunstein, D.N., A behaviorally-based measure of manifest needs in work settings, Journal of Vocational Behavior, 1976, 9, 251-266.

Steers, R.M. \& Rhodes, S.R., Major influences on employee attendance: a process model, Journal of Applied Psychology, 1978, 63, 391-407.

Steers, R.M. \& Spencer, D.G., The role of achievement motivation in job design, Journal of Applied Psychology, 1977, 62, 472-479.

Stinson, J.E. \& Johnson, T.W., The Path-Goal Theory of Leadership" a partial test and suggested refinement, Academy of Management Journal, 1975, 18, 242-252.

Stoffels, R., Arbeidstevredenheid, stress en copingstrategieën van verpleegkundigen, werkzaam op een algemene verpleegafdeling, Doctoraalscriptie, vakgroep Verplegingswetenschap, Rijksuniversiteit Limburg, Maastricht, 1985.

Stogdill, R.M., Manual for the Leader Behavior Description Question- naire - Form XII, Columbus, Bureau of Business Research, The Ohio State University, 1963.

Stogdill, R.M., Handbook of Leadership, The Free Press, New York, 1974.

Stone, E.F., Moderating effect of work-related values in the job scope-job satisfaction relationship, Organizational Behavior and Human Performance, 1976, 15, 147-167.

Stone, E.F., Job scope-job satisfaction and job scope-job performance relationships, in: Locke, E.A. (ed.), Generalizing from laboratory to field settings, Lexington, MA: Lexington Books, 1986, 189-206.

Stone, G.L. Jebsen, G.L., Walk, P. \& Belsham, R., Identification of stress and coping skills within a critical care setting, Western Journal of Nursing Research, 1984, 6, 201-211.

Stone, E.F., Mowday, R.T. \& Porter, L.W., Higher-order need strengths as moderators of the job scope-job satisfaction relationship, Journal of Applied Psychology, 1977, 62, 468-473.

Stone, E.F. en Porter, L.W., Job characteristics and job attitudes: a mulivariate study, Journal of Applied Psychology, 1975, 60, 57-64.

Stone, E.F. \& Porter, L.W., On the use of incumbent-supplied job characteristics data, Perceptual and Motor Skills, 1978, 46, 751-758.

Strien, P.J. van, Wat betekent humanisering van de arbeid, in: Humanisering van de arbeid, Galan, C. de, Gils, M.R. van \& Strien, P.J. van (red.), Van Gorcum, Assen, 1980, $15-47$.

Swanborn, P.G., Methoden van sociaal-wetenschappelijk onderzoek: inleiding in ontwerpstrategieën, Boom Meppel, Amsterdam, 1981.

Szilagyi, A.D. \& Sims, H.P., An exploration of the path-goal theory of leadership in a health care environment, Academy of Management Journal, 1974, 17, 622-634.

Taber, T.D., Beebr, F.A. \& Walsh, J.T., Relationships between job evaluation ratings and self-ratings of job characteristics, Organizational behavior and Human Decision Processes, $1985,35,27-45$.

Thierry, H. \& Koopman-Iwema, A.M., Motivatie en satisfactie, in: Drenth, P.J.D., Thierry, H., Willems, P.J. \& Wolf, Ch. J. de (ed.), Handboek Arbeids- en Organisatiepsychologie, deel I, Van Loghum Slaterus, Deventer, 1983.

Thoits, P.A., Social support as coping assistence, Journal of Consulting and Clinical Psychology, $1986,54,416-423$.

Thomas, J. \& Griffin, J., The Social Information Processing Model of task design: a review of the literature, Academy of Management Review, 1983, 8, 672-682.

Turner, A.N. \& Lawrence, P.R., Industrial jobs and the worker: an investigation of response to task attributes, Harvard University, Boston, 1965. 
Umstot, D.D., Bell, C.H. \& Mitchell, T.R., Effects of job enrichment and task goals on satisfaction and productivity: implications for job design, Journal of Applied Psychology, $1976,61,379-394$.

Vergert, H.G.M. ten, Ziekteverzuim in een verpleeghuis, Doctoraalscriptie, Vakgroep Verplegingswetenschap, Rijksuniversiteit Limburg, Maastricht, 1987.

Vliert, E. van de \& Boer, F. de, Sociale steun als determinant van gezondheid: suggesties voor verder onderzoek, Gezondheid en Samenleving, 1984, 5, 2-8.

Vreeland, R. \& Ellis, G.L., Stresses on the nurse in an intensive care unit, JAMA, 1969, 208, 332-334.

Vroom, V.H., Work and Motivation, Wiley, New York, 1964.

Wall, T.D., Clegg, C.W. \& Jackson, P.R., An evaluation of the job characteristics model, Journal of Occupational Psychology, 1978, 51, 183-196.

Wall, T.D. \& Martin, R., Job and work design, in: Cooper, C.L. \& Robertson, 1.T. (ed.), International Review of Industrial and Organizational Psychology, 1987, 61-91.

Wallis, D., Satisfaction, stress, and performance: issues for occupational psychology in the "caring" professions, Work and Stress, 1987, 1, 11.3-128.

Walsh, A \& Bruni, N., Satisfaction and dissatisfaction at the workplace, The Australian Nurses Journal, 1983, 12, 38-39.

Wanous, J.P., Individual differences and reactions to job characteristics, Journal of Applied Psychology, 1974, 59, 616-622.

Weisman, C.S., Alexander, Ch. S. \& Chase, G.A., Job satisfaction among hospital nurses: a longitudinal study, Health Services Research, 1980, 15, 341-364.

Weisman, C.S., Alexander, Ch. S. \& Chase, G.A., Determinants of hospital staff turnover, Medical Care, 1981, 19, 431-443.

Weiss, H.M. \& Shaw, J.B., Social influences on judgements about tasks, Organizational Behavior and Human Performance, 1979, 24, 126-140.

White, J.K. Individual differences and the job quality-worker response relationship: review, integration, and comments, Academy of Management Review, 1978, 3, 267-280.

White, C.H. \& Maguire, M.C., Job satisfaction and dissatisfaction among hospital nursing supervisors: the applicability of Herzberg's theory, Nursing Research, 1973, 22, 25-30.

Willige, G. van de, Sorbi, M., Kluwer, R., Godaert, G., Schreurs, P. \& Vink, J., Gedrag en gezondheid: een interactionele benadering, Gezondheid en Samenleving, 1983, 4, 32-41.

Winnubst, J.A.M., Marcelissen, F.H.G. \& Kleber, R.J., Effects of social support in the stressor-strain relationship: a Dutch sample, Social Science Medicine, 1982, 16, 475-482.

Zwaga, P.G.J., Invloed van leiderschaps en communicatie-klimaat op stress en satisfactie van (leerling)verpleegkundigen in algemene ziekenhuizen, Instituut voor Sociale Psychologie, Rijksuniversiteit Utrecht, 1981.

Zwaga, P.G.J., Rolproblemen in algemene ziekenhuizen: enige effecten, Dissertatie, Van Gorcum, Assen, 1983. 


\section{BIJLAGE 1}

Brief gericht aan de Directie van de ziekenhuizen

Zeer geachte Directie,

In september 1985 is aan de Rijksuniversiteit Limburg begonnen met de voorbereiding van een onderzoek, dat zich richt op de kenmerken van werk en de reacties daarop van verpleegkundigen van ICU's en algemene verpleegafdelingen. Dit onderzoek maakt het mogelijk potentiele knelpunten binnen beide situaties op te sporen en toekomstig beleid te ondersteunen ten aanzien van het organisationele ontwerp van de afdeling, doelgerichte opleidings- en bijscholingsprogramma's en selectie- en loopbaan begeleiding. Onder begeleiding van Prof. dr. J. Bremer en dr. J.A. Landeweerd, beiden verbonden aan de vakgroep Medische Psychologie, wordt dit (promotie-)onderzoek uitgevoerd door ondergetekende, doctorandus Gezondheidswetenschappen met afstudeerrichting Verplegingswetenschap. Na afronding van de voorbereidingsfase zal begin 1987 gestart worden met het hoofdonderzoek, waarin een zestiental a-select gekozen algemene, academische en categorale ziekenhuizen betrokken worden.

Conform de onderzoeksopzet wordt beoogd binnen elk ziekenhuis in nader overleg een ICU en een algemene verpleegafdeling te betrekken in het onderzoek. De verpleegkundigen van deze afdelingen zal gevraagd worden een enquête in te vullen; de duur is maximaal een uur per persoon.

Uw ziekenhuis is een van de zestien ziekenhuizen uit de steekproef. Onze vraag is of u medewerking wilt verlenen aan het onderzoek binnen uw instelling. Wij hopen op uw bereidheid tot een gesprek op korte termijn tussen $u$, het hoofd van de verplegingsdienst en ons, waarin een nadere toelichting op het onderzoek gegeven zal worden. Gaarne zullen wij in de loop van de maand januari telefonisch met $u$ een afspraak voor dit gesprek maken.

Ter uwer informatie kunnen wij mededelen dat zowel de Nationale Ziekenhuisraad, als de belangenvereniging voor verpleegkundigen en verzorgende "Het Beterschap" en de Nederlandse Vereniging voor Intensive Care aan het belang van dit onderzoek hun adhesie hebben betuigd.

Hoogachtend,

Prof. dr. J.J.C.B. Bremer

Drs. N.P.G. Boumans

Dr. J.A. Landeweerd 


\section{BIJLAGE 2}

Overzicht gemiddelden en standaardwariaties van alle variabelen $(n=561)$

(bij verzulmdimensies $n=427$ )

VARLABELEN

GEM

S.D.

Schaol taakkenmerken:

complexiteit/moeilijkheid

$5.57 \quad .98$

feedback/duidelijkheid

$4.79 \quad .77$

werkdruk

$4.64 \quad .94$

autonomie

$4.601 \quad 98$

promotie/groei

$3.73 \quad 1.19$

verzorgende/begelleidende activiteiten

5.40

Schaal heiderschapsstijl.

sociaal-emotioneel leiderschapstijl

3.70

.67

instrumenteel lleiderschapsstijl

2.89

Schaal verpleegsysteen:

taakgericht (us patiêni) verplegen

2.89

Schaal eigen werkwaandering*

algemene werkvoldoening

3.97

.60

ervaren belasting

2.77

.76

ervaren verantwoordelijkheid

4.05

.66

interne werkmotivatie

4.58

.47

ervaren betekenis

4.34

.48

kennis van resultaten

2.92

.52

Schaal satisfactie:

tevredenheid met kwalliteit van zorg

3.43

.67

tewredenheid met afdelingshoofd

3.45

.77

tevredenheid met contacten collega's

3.91

.41

tevredenheid met promotiemogelijkheden

2.58

.68

tevredenheid inet contacten patienten

3.79

.42

tewredenheid met duidelijkheid

3.58

.44

tevredenheid met groeimogelijkheden

3.68

.58

Schalen gezondheidsklachaten:

algemene mallaise

1.31

.30

ervaren bartklachten

1.25

.47

gespannenheid/nervositeit

1.56

.38

Beprikkeldheid

$2.01 \quad .50$

depressiviteit

1.40

.37

Veratumdimensies:

veranimfrequentie

1.18

1.31

totale verzuimdurur

7.94

16.39 


\begin{tabular}{|c|c|c|}
\hline VARLABELEN & GEM. & S.D. \\
\hline \multicolumn{3}{|l|}{ Tweede-orde-factoren: } \\
\hline Arbeidstevredenheid & 3.55 & .38 \\
\hline gezondheidsklachten & 1.71 & .33 \\
\hline eigen werkwaardering & 4.32 & .39 \\
\hline \multicolumn{3}{|l|}{ Schaal sociale ondersteuning: } \\
\hline steun van (leerling) verpleegkundigen & 3.35 & .40 \\
\hline steun van afdelingshoofd & 3.22 & .58 \\
\hline steun van andere mensen op het werk & 2.43 & .59 \\
\hline steun van vrienden of verwanten & 3.05 & .68 \\
\hline stewn van de partner & 3.57 & .46 \\
\hline steun vanuit de werksituatie & 3.16 & .37 \\
\hline steun vanuit de thuissituatie & 3.27 & .47 \\
\hline \multicolumn{3}{|l|}{ Schaal coping: } \\
\hline palliatieven & 2.12 & .43 \\
\hline sociale steun zoeken & 2.39 & .49 \\
\hline actief-probleem-aanpakkem & 2.70 & .39 \\
\hline depressief reactiepatroon & 1.42 & .34 \\
\hline afwachten en vermijden & 1.81 & .35 \\
\hline comforting cognitions & 2.23 & .46 \\
\hline uiten van emoties & 2.09 & .50 \\
\hline \multicolumn{3}{|l|}{ Schaal preferenties: } \\
\hline preferentie voor carrière & 3.59 & .82 \\
\hline preferentie voor prestige & 3.48 & .75 \\
\hline preferentie voor autonomie & 3.55 & .62 \\
\hline preferentie voor samenwerken & 3.68 & .58 \\
\hline preferentie voor afwisseling & 3.74 & .56 \\
\hline preferentie voor ontbreken tijdsdruk & 3.83 & .65 \\
\hline \multicolumn{3}{|l|}{ Schaal biografische kenmerken: } \\
\hline diensttijd in ziekenhuis & 6.98 & 4.83 \\
\hline diensittijd in de werpleging & 9.52 & 6.00 \\
\hline diensttijd op de afdeling. & 3.70 & 3.86 \\
\hline leeftijd & 28.82 & 6.61 \\
\hline
\end{tabular}




\section{BIJLAGE 3}

Resultaten tweede-orde-factor- en betrouwbaarheidsanalyses

Factor 1: Arbeidsterredenheid (Cronbach's alpha: $=0.80)$

item:

factorlading:

-tevredenheid met gnoeirmogellijkheden

.70

- tovredenheid met duidelifkheid

68

-algemente werkwoldoening

58

- Hevredenheid met kwaliteit van zorg

51

- Hevredienheid contacten collega's

51

-tevredenbeid afdelingshoofd

.49

-tevredenheid contaten patienten

.44

-tewredenheid promotiemogelijkheden

.42

Factor 2: Gezondheidsklachten (Cronbach's alpha $=0.75$ )

ittem:

-gespannenheid/nervositeit

factorlading: - ervaren belasting

74

.72

-allgemene malaise

.66

- depressiviteit

61

- ervaren hartklachten

.44

-geprikkeldheid

44

Factor 3. Eigen werkwacurdering (Cronbach's alpha $=0.56$ )

item:

factorlading:

-interne werkmotivatie

58

-ervaren betekenis

57

-ervaren verantwoordelijkheid

.40

Percentage verklaarde wariantie: $38 \%$ 


\section{BLJLAGE 4}

\section{Intercorrelaties oorspronkelijke reactie-variabelen $(n=561)$}

we1 we2 we3 we4 wes we6 tel te2 te3 te4 tes te6 te7 gez1 gez2 gev1 gev2 gev3

\begin{tabular}{|c|c|c|c|c|c|c|c|c|c|c|c|c|c|c|c|c|c|}
\hline we1 = & -.22 & .16 & .40 & .48 & 13 & 32 & .40 & .36 & 31 & .26 & .48 & .65 & -.18 & -.07 & -23 & -33 & -17 \\
\hline we? & $=$ & -.03 & .11 & -.12 & -26 & -.35 & -.19 & -.19 & -11 & -.13 & -.32 & -.16 & .49 & 31 & .58 & .36 & 44 \\
\hline we3 & & - & .21 & .36 & .00 & .09 & .09 & .17 & .07 & -.01 & .19 & .19 & -.04 & -.04 & -.10 & -.05 & -.05 \\
\hline we 4 & & & - & .35 & -.05 & .09 & .13 & .22 & .17 & .13 & 19 & .24 & $-0,03$ & -.04 & -.05 & -.05 & -.03 \\
\hline we 5 & & & & - & .12 & .26 & .28 & 32 & .26 & 18 & .42 & .45 & -.15 & -.08 & -21 & -.25 & -16 \\
\hline we6 & & & & & - & .13 & .14 & .12 & .07 & .03 & .20 & .16 & -.13 & -.10 & -23 & -.18 & -.24 \\
\hline teil & & & & & & - & .19 & .24 & .18 & .37 & .44 & .42 & -.20 & -.113 & -25 & -26 & -19 \\
\hline te2 & & & & & & & - & .40 & 41 & .13 & .46 & 39 & -.18 & -.10 & -.20 & -.35 & -21 \\
\hline tee 3 & & & & & & & & $=$ & .27 & .29 & .53 & .47 & -.16 & -.11 & -.29 & -.22 & -30 \\
\hline ted & & & & & & & & & - & .16 & .33 & .32 & -.07 & -.13 & -.08 & -31 & -.15 \\
\hline tes & & & & & & & & & & - & .29 & .27 & -.04 & -.04 & -10 & $=.09$ & .04 \\
\hline te6 & & & & & & & & & & & $=$ & .56 & -.26 & -.15 & -40 & -.42 & -31 \\
\hline te7 & & & & & & & & & & & & - & -.16 & -.06 & -22 & -32 & .17 \\
\hline gezl & & & & & & & & & & & & & $=$ & .44 & .49 & .29 & .40 \\
\hline gez2 & & & & & & & & & & & & & & $=$ & .30 & .24 & .20 \\
\hline gevll & & & & & & & & & & & & & & & $\sim$ & 38 & .54 \\
\hline gev2 & & & & & & & & & & & & & & & & - & 37 \\
\hline gev3 & & & & & & & & & & & & & & & & & * \\
\hline
\end{tabular}

* correlaties hoger dan .08 zijn significant op nivean 05 (tweezijdig)

* correlaties hoger dan 11 zjin significant op niveau .01 (tweezijdig)

*** correllaties hoger dan .14 zjjn significant op niveau .001 (tweezijdig)

Lijst met gebruikte afkortingen bij BIJLAGE 4:

we1: algemene werkvoldoening

we2: ervaren belasting

we 3: ervaren verantwoordelijkheid

we4: interne werkmotivatie

we5: ervaren betekenis

we6: kennis van resultaten

te1: tevredenheid met kwaliteit van zorg

te: $\quad$ tevredenheid met afdelingshoofd

te3: tevredenheid met contacten collega's

te4: tevredenheid met promotiemogelijkheden

te5: tevredenheid met contacten patienten

te6: tevredenheid met duidelijkheid

te7: tevredenheid met groeimogelijikheden

gez1: algemene malaise

gez2: ervaren hartklachten

gev1: gespannenheid/nerwositeit

gev2: geprikkeldheid

gev3: depressiviteit 


\section{BIJLAGE 5}

\section{Intercorrelaties individuele/psychosociale kenmerken $(\mathbf{n}=561)$}

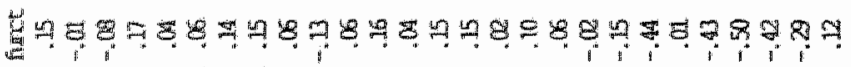

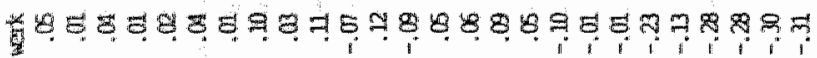

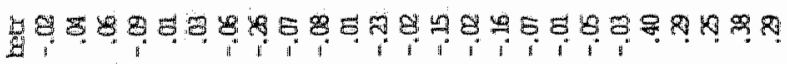

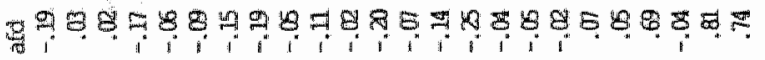

94.

년

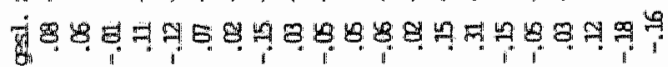

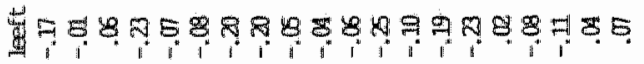

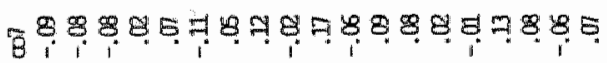

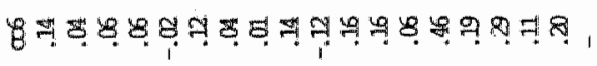

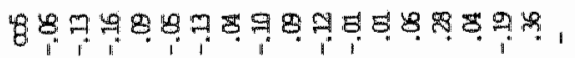

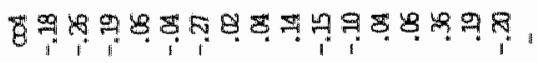

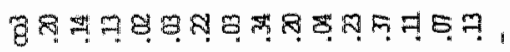

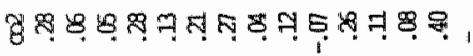

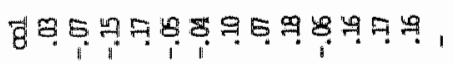

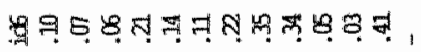

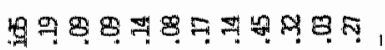

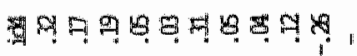

$98,8,8,8,8 \%$

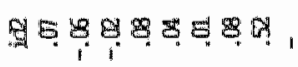

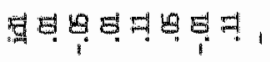

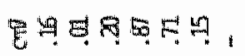

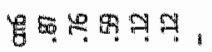

"

ํํำ 무

․․

管寻内

을 구

है। 
Lijst met gebruikte afkortingen bij] BIILAGE 5:

om1: sociale steun door gediplomeerd- en leerling-verpleegkundigen

om2: sociale steun door afdelingshoofd

om3: sociale stewn door andere mensen op het werk

om4: sociale steun door vrienden of verwanten

om5: sociale steun door partner

om6: sociale steun vanuit de werksituatie

om7: sociale steun wamuit de thuissituatie

id1: preferentie voor carriere

id2: preferentic voor prestige

id3: preferentie voor autonomie

id4: preferentie woor samenwerken

id5: preferentie voor afwisseling

id6: preferentie voor ontbreken tijdsdruk

co1: palliatieven

co2: $\quad$ sociale steun zoeken

co3: actief-probleem-aanpakken

co4: depressief reactiepatroon

co5: afwachten/vermijden

co6: comforting cognitions

co7: uiten van emoties

leeft: leeftijd in jaren

gesl: geslacht; man-vrouw

zhs: jaren werkzaam in het zickenbuis

verp: jaren werkzaam in de verpleging

afd: jaren werkzaam op de afdeling

betrek: soort betrekking; fulltime-parttime

werk: werktijd; vaste-wisselende diensten

funct: functie; gediplomeerd-leerling 


\section{BIJLAGE 6}

Correlaties tussen de biografische kenmerken en de (nieuwe) reactie-variabelen $(n=561)$ (bij werzuimfrequentie $n=\mathbf{4 2 7}$ )

\begin{tabular}{|c|c|c|c|c|}
\hline \multirow{2}{*}{$\begin{array}{l}\text { biografische } \\
\text { kerinerkem: }\end{array}$} & \multicolumn{4}{|c|}{ reactie-wariabelen: } \\
\hline & tevredh. & gezklacht & werkw. & freq(log) \\
\hline 1. leeftijd & -.01 & -.03 & $.15^{* * *}$ &. .05 \\
\hline 2. gesllacht & $.21^{* * *}$ & -.03 & $13^{* *}$ & -.04 \\
\hline 3. betrek & .03 & -.07 & $.18^{* * * *}$ & -.06 \\
\hline 4, werlatijd & .02 & -.01 & -.08 & -.01 \\
\hline 5. functive & $.11^{*}$ & -.01 & -.08 & $10^{*}$ \\
\hline 6. zhs. & .05 & .01 & $.18 * * *$ & -.05 \\
\hline 7. verp. & $-_{n} 01$ & .01 & $.15^{* * *}$ & -.02 \\
\hline 8. afid. & .01 & .04 & $.15 * * *$ & -.05 \\
\hline
\end{tabular}

*** $\mathrm{p} \leq 0.001 ; * * \mathrm{p} \leq 0.01 ; * \mathrm{p} \leq 0.05$ (tweexijdig) 


\section{BIJLAGE 7}

Resultaten stapsgewijze regressie-analyses van tevredenheid, gezondheidsklachten, eigen werkwaardering en verzuimfrequentie met de acht biografische kenmerken als predictor-variabelen op individueel niveau $(n=561$ ) (bij verzuimfrequentie $n=427$ )

\begin{tabular}{|c|c|c|c|c|}
\hline predictor & $\begin{array}{l}\text { criterium } \\
\text { tevredh. }\end{array}$ & gez.klacht & werkw. & freq. $(\log )$ \\
\hline 1. leeftijd & $\left.--^{*}\right)$ & $\cdots$ & $\cdots$ & $\cdots$ \\
\hline 2. geslacht & .20 & $\ldots$ & .11 & $\cdots$ \\
\hline 3. betrek. & --- & --- & .12 & $\cdots$ \\
\hline 4. werktijd & $-\cdots$ & $\cdots$ & $\cdots$ & $\cdots$ \\
\hline 5. functie & .16 & $\cdots$ & $\cdots$ & .10 \\
\hline 6. zhs. & .12 & $\cdots$ & .15 & $\ldots$ \\
\hline 7. verp. & $\cdots$ & -- & $\cdots$ & $\cdots$ \\
\hline 8. afd. & $-\cdots$ & $\cdots$ & $\cdots$ & $\cdots$ \\
\hline$R(p \leq 0.05)$ & .24 & .00 & 25. & 10 \\
\hline$\overline{\mathrm{R}^{2}}$ & .06 & .00 & .06 & .01 \\
\hline
\end{tabular}

*) beta's 


\section{BIJLAGE 8}

"Behoefte aan autonomie": resultaten subgroep-regressie-analyses (mediaan $=3.571$ ) a)

\begin{tabular}{|c|c|c|c|c|c|c|c|}
\hline predictor & criterium & n & p/Fch & $\mathrm{b}$ & $\mathrm{SEb}$ & $\mathrm{a}$ & $T$ \\
\hline $\begin{array}{l}\text { instrumetileel } \\
\text { leiderschap }\end{array}$ & tevredenheid & $\begin{array}{l}\text { 1) } 226 \\
\text { 2) } 266 \\
\text { 3) } 496\end{array}$ & $\begin{array}{l}.018 \\
.526 \\
.239\end{array}$ & $\begin{array}{r}.122 \\
-.025 \\
.035\end{array}$ & $\begin{array}{l}.051 \\
.039 \\
.030\end{array}$ & $\begin{array}{l}2.97 \\
3.41 \\
3.22\end{array}$ & 2.297 \\
\hline $\begin{array}{l}\text { instrumented } \\
\text { leiderschap }\end{array}$ & $\begin{array}{l}\text { gezondhelds } \\
\text { klachten }\end{array}$ & $\begin{array}{l}\text { 1) } 234 \\
\text { 2) } 284 \\
\text { 3) } 526\end{array}$ & $\begin{array}{l}.849 \\
.006 \\
.037\end{array}$ & $\begin{array}{r}-.008 \\
.090 \\
.054\end{array}$ & $\begin{array}{l}.045 \\
.033 \\
.026\end{array}$ & $\begin{array}{l}1.84 \\
1.44 \\
1.59\end{array}$ & 1.750 \\
\hline $\begin{array}{l}\text { feedback/ } \\
\text { dwidelijkheid(log) }\end{array}$ & verzuimfreq. & $\begin{array}{l}\text { 1) } 168 \\
\text { 2) } 221 \\
\text { 3) } 395\end{array}$ & $\begin{array}{l}.315 \\
.061 \\
.288\end{array}$ & $\begin{array}{r}.026 \\
-.036 \\
-.016\end{array}$ & $\begin{array}{l}.026 \\
.019 \\
.015\end{array}$ & $\begin{array}{l}0.24 \\
0.41 \\
0.38\end{array}$ & 1.858 \\
\hline autonomie & $\begin{array}{l}\text { verzuimfreq. } \\
(\log )\end{array}$ & $\begin{array}{l}\text { 1) } 178 \\
\text { 2) } 230 \\
\text { 3) } 415\end{array}$ & $\begin{array}{l}.044 \\
.580 \\
.559\end{array}$ & $\begin{array}{r}.041 \\
-.009 \\
.007\end{array}$ & $\begin{array}{l}.020 \\
.016 \\
.012\end{array}$ & $\begin{array}{l}0.18 \\
0.28 \\
0.27\end{array}$ & 2.033 \\
\hline $\begin{array}{l}\text { taak (versus } \\
\text { patient)verpl. }\end{array}$ & $\begin{array}{l}\text { verzuimfreq. } \\
\text { (log) }\end{array}$ & $\begin{array}{l}\text { 1) } 163 \\
\text { 2) } 217 \\
\text { 3) } 387\end{array}$ & $\begin{array}{l}.974 \\
.000 \\
.005\end{array}$ & $\begin{array}{l}.001 \\
.056 \\
.035\end{array}$ & $\begin{array}{l}.020 \\
.016 \\
.012\end{array}$ & $\begin{array}{l}0.41 \\
0.12 \\
0.24\end{array}$ & $\begin{array}{l}2.278 \\
* *\end{array}$ \\
\hline
\end{tabular}

a) gecorrigeerd voor de effecten van de vier controle-variabelen "geslacht", "functie", "soort betrekking" en "jaren werkzaam in het ziekenhuis" in de eerste stap van de regressie..

$\mathrm{n}=$ grootte subgroepen ("1 $=$ scores $<$ mediaan" en "2 $=$ scores $>$ mediaan" en " $3=$ scores totale groep")

$\mathrm{p} / \mathrm{Fch}=$ overschrijdingskans van de F-waarde verkregen bij de toetsing van de multiple correlatie na toevoeging van de predictor aan de vier controle variabelen

b $\quad=$ regressiecoëfliciënt

SEb = standaarderror regressiecoefficiènt

a $=$ constante

$\mathrm{T}=\mathrm{t}$-waarde verkregen bij toetsing werschillen tussen de subgroep regressiecoëfficiënten $(* \mathrm{p} \leq 0.05, * \mathrm{p} \leq 0.1)$ 


\section{BIJLAGE 9}

\begin{tabular}{|c|c|c|c|c|c|c|c|}
\hline predictor & criterium & $\pi$ & $\mathrm{p} / \mathrm{Fch}$ & $\mathrm{b}$ & $\mathrm{SEb}$ & $a$ & $\mathrm{~T}$ \\
\hline werkdruk & tevredenheid & $\begin{array}{l}\text { 1) } 224 \\
\text { 2) } 204 \\
\text { 3) } 497\end{array}$ & $\begin{array}{l}.005 \\
.996 \\
.000\end{array}$ & $\begin{array}{c}-.067 \\
.00011 \\
-.074\end{array}$ & $\begin{array}{l}.024 \\
.023 \\
.017\end{array}$ & $\begin{array}{l}3.44 \\
3.65 \\
3.67\end{array}$ & 2.030 \\
\hline autonomie & terredenheid & $\begin{array}{l}\text { 1) } 226 \\
\text { 2) } 205 \\
\text { 3) } 500\end{array}$ & $\begin{array}{l}.000 \\
.234 \\
.000\end{array}$ & $\begin{array}{r}.088 \\
.028 \\
.102\end{array}$ & $\begin{array}{l}.022 \\
.024 \\
.017\end{array}$ & $\begin{array}{l}2.72 \\
3.52 \\
2.87\end{array}$ & 1.818 \\
\hline $\begin{array}{l}\text { promotiel } \\
\text { groei }\end{array}$ & tevredenheid & $\begin{array}{l}\text { 1) } 222 \\
\text { 2) } 203 \\
\text { 3) } 496\end{array}$ & $\begin{array}{l}.000 \\
.000 \\
.000\end{array}$ & $\begin{array}{l}.141 \\
.088 \\
.146\end{array}$ & $\begin{array}{l}.018 \\
.018 \\
.013\end{array}$ & $\begin{array}{l}2.70 \\
3.29 \\
2.82\end{array}$ & $\underset{*}{2,208}$ \\
\hline autonomie & $\begin{array}{l}\text { gezondheids- } \\
\text { klachten }\end{array}$ & $\begin{array}{l}\text { 1) } 238 \\
\text { 2) } 214 \\
\text { 3) } 528\end{array}$ & $\begin{array}{l}.000 \\
.273 \\
.000\end{array}$ & $\begin{array}{l}-.089 \\
-.022 \\
-.077\end{array}$ & $\begin{array}{l}.023 \\
.021 \\
.015\end{array}$ & $\begin{array}{l}2.26 \\
1.70 \\
2.10\end{array}$ & 2.233 \\
\hline $\begin{array}{l}\text { promotie/ } \\
\text { groei }\end{array}$ & $\begin{array}{l}\text { gezondheids- } \\
\text { klachten }\end{array}$ & $\begin{array}{l}\text { 1) } 233 \\
\text { 2) } 212 \\
\text { 3) } 522\end{array}$ & $\begin{array}{l}.081 \\
.281 \\
.037\end{array}$ & $\begin{array}{r}-.036 \\
.018 \\
-.026\end{array}$ & $\begin{array}{l}.021 \\
.017 \\
.058\end{array}$ & $\begin{array}{l}1.98 \\
1.54 \\
1.85\end{array}$ & 2.077 \\
\hline werkdruk & $\begin{array}{l}\text { eigen } \\
\text { werkwaardering }\end{array}$ & $\begin{array}{l}\text { 1) } 242 \\
\text { 2) } 213 \\
\text { 3) } 537\end{array}$ & $\begin{array}{l}.917 \\
.015 \\
.648\end{array}$ & $\begin{array}{r}-.003 \\
.064 \\
.008\end{array}$ & $\begin{array}{l}.029 \\
.026 \\
.018\end{array}$ & $\begin{array}{l}4.08 \\
3.91 \\
4.09\end{array}$ & ${ }_{*}^{1.718}$ \\
\hline autonomie & $\begin{array}{l}\text { eigen } \\
\text { werkwaardering }\end{array}$ & $\begin{array}{l}\text { 1) } 243 \\
\text { 2) } 214 \\
\text { 3) } 539\end{array}$ & $\begin{array}{l}.000 \\
.995 \\
.000\end{array}$ & $\begin{array}{l}.106 \\
.0002 \\
.074\end{array}$ & $\begin{array}{l}.027 \\
.028 \\
.017\end{array}$ & $\begin{array}{l}3.59 \\
4.23 \\
3.80\end{array}$ & $\underset{* 4 \times}{2.713}$ \\
\hline $\begin{array}{l}\text { promotie/ } \\
\text { groel }\end{array}$ & $\begin{array}{l}\text { eigen } \\
\text { werkwaardering }\end{array}$ & $\begin{array}{l}\text { 1) } 238 \\
\text { 2) } 212 \\
\text { 3) } 532\end{array}$ & $\begin{array}{l}.000 \\
.113 \\
.000\end{array}$ & $\begin{array}{l}.093 \\
.036 \\
.075\end{array}$ & $\begin{array}{l}.024 \\
.022 \\
.014\end{array}$ & $\begin{array}{l}3.77 \\
4.07 \\
3.87\end{array}$ & 1.727 \\
\hline
\end{tabular}

a) gecorrigeerd voor de effecten wan de vier controle-variabelen "geslacht", "functie", "soort" betrekking" en "jaren werkzaam in het ziekenhuis" in de eerste stap van de regressic.

$\mathrm{n} \quad=$ grootte subgroepen ("1 = scores < mediaan" en "2 $=$ scores $>$ mediaan" en "3 = scores totale groep")

$\mathrm{p} / \mathrm{Fch}=$ overschrijdingskans van de F-waarde verkregen bij de toetsing van de multiple correlatie na toevoeging van de predictor aan de vier controle variabelen

b = regressiecoëfficiënt

$\mathrm{SEb}=$ standaarderror regressiccoëfficiènt

a $=$ constante

$\mathrm{T} \quad=\mathrm{t}$-waarde verkregen bij toetsing verschillen tussen de subgroep regressiecoëfficiènten (*** $\mathrm{p} \leq 0.01$, ${ }^{* *} \mathrm{p} \leq 0.05,{ }^{*} \mathrm{p} \leq 0.1$ ) 
BIJLAGE 10

Overzicht resultaten wan diverse onderzoeken met betrekking tot moderator-functie van soclale ondersteuming

\begin{tabular}{|c|c|c|c|c|c|}
\hline \multirow[t]{2}{*}{ Studie: } & \multirow[t]{2}{*}{ Predictior } & \multirow[t]{2}{*}{ Criterium } & \multirow[t]{2}{*}{ soort steun } & \multicolumn{2}{|c|}{ percentage gevonden gemiddeld percentage } \\
\hline & & & & buffereffecten & over gehele studie \\
\hline $\begin{array}{l}\text { LaRocco } \\
(1980)\end{array}$ & $\begin{array}{l}\text { rolconflict } \\
\text { toekonstonz. } \\
\text { "underwtiliz" } \\
\text { participatie } \\
\text { werkbelasting }\end{array}$ & $\begin{array}{l}\text { arbeidsontevr. } \\
\text { vervelling } \\
\text { ontevr. met } \\
\text { werkbelasting. }\end{array}$ & chef & 20 & \\
\hline $\begin{array}{l}\text { Lakocco } \\
(1980)\end{array}$ & idem & idem & collega"s & 13.3 & \\
\hline $\begin{array}{l}\text { LaRocco } \\
(1980)\end{array}$ & idem & $\begin{array}{l}\text { depressie } \\
\text { irritatie } \\
\text { angst } \\
\text { somat.klacht. }\end{array}$ & cheif & 13.3 & $\begin{array}{l}17.7 \\
(\text { LaRocco, 1980) }\end{array}$ \\
\hline $\begin{array}{l}\text { LaRocco } \\
(1980)\end{array}$ & idem & idem & collega's & 24.4 & \\
\hline $\begin{array}{l}\text { Reiche } \\
\text { (1982) } \\
\text { (middenkader) }\end{array}$ & (VOS, 1979) & (VOS, 1979) & chef & 8.3 & \\
\hline $\begin{array}{l}\text { Reiche } \\
\text { (1982) } \\
\text { (middenkader) }\end{array}$ & idem & idem & collega"s & 5.4 & \\
\hline $\begin{array}{l}\text { Reiche } \\
\text { (1982) } \\
\text { (bazem) }\end{array}$ & idem & idem & chef & 3.1 & $\begin{array}{l}4 \\
\text { (Reiche, 1982) }\end{array}$ \\
\hline $\begin{array}{l}\text { Reiche } \\
\text { (1982) } \\
\text { (bazen }\end{array}$ & idem; & idem & collega's & 4.9 & \\
\hline $\begin{array}{l}\text { Winnubst e.a } \\
\text { (1982) }\end{array}$ & $\begin{array}{l}\text { rolconflict } \\
\text { rolambiguit. } \\
\text { roloverbel. } \\
\text { werantwoord. } \\
\text { toekomston: }\end{array}$ & $\begin{array}{l}\text { bedreiging } \\
\text { irritatie } \\
\text { depressie } \\
\text { angst } \\
\text { roken } \\
\text { drinken }\end{array}$ & chef & 23.3 & \\
\hline $\begin{array}{l}\text { Winnubst e.a } \\
\text { (1982) }\end{array}$ & idem & idem & collega's & 26.7 & \\
\hline $\begin{array}{l}\text { Winnubst e.a } \\
\text { (1982) }\end{array}$ & idem & $\begin{array}{l}\text { hartklacht. } \\
\text { alg.gezondlh. } \\
\text { syst.blocd. } \\
\text { diast.bloed. } \\
\text { cholesterol }\end{array}$ & chef & 12 & $\begin{array}{l}18.5 \\
\text { (Winnubst e.a., 1982) }\end{array}$ \\
\hline $\begin{array}{l}\text { Wimnubst e.a. } \\
\text { (1982) }\end{array}$ & idem & idem & collega's & 12 & \\
\hline
\end{tabular}


Vervolg overzicht resultaten van diverse onderzoeken met betrekking tot moderator-functie van sociale ondersteuning

\begin{tabular}{|c|c|c|c|c|c|}
\hline $\begin{array}{l}\text { Marcelissen } \\
\text { (1987) }\end{array}$ & $\begin{array}{l}\text { rolambiguit. } \\
\text { rolconflict } \\
\text { verantw. } \\
\text { overbelasting } \\
\text { toekomstonz. } \\
\text { syst.bloed. } \\
\text { diast.bloed. } \\
\text { cholesterol }\end{array}$ & $\begin{array}{l}\text { psych.klacht } \\
\text { inc.gez.klacht } \\
\text { regm.gez.klacht } \\
\text { bezorgdheid } \\
\text { Quetelet }\end{array}$ & chef & 18.8 & $\begin{array}{l}9.4 \\
\text { (Marcelissen, 1987) }\end{array}$ \\
\hline $\begin{array}{l}\text { Marcelissen } \\
(1987)\end{array}$ & idem & idem & collega's & 0 & \\
\hline $\begin{array}{l}\text { Norbeck * } \\
\text { (1985) }\end{array}$ & werkstress & arbeidsontevr. & tot.score ** & 0 & $\begin{array}{l}0 \\
\text { (Norbeck, 1985) }\end{array}$ \\
\hline $\begin{array}{l}\text { Peiro* } \\
\text { (1986) }\end{array}$ & $\begin{array}{l}\text { rolconflict } \\
\text { rolambiguit. }\end{array}$ & $\begin{array}{l}\text { arbeidstevr. } \\
\text { spanning werk } \\
\text { verloopgeneidh. }\end{array}$ & structurele & 0 & 16.7 \\
\hline $\begin{array}{l}\text { Peiro* } \\
(1986)\end{array}$ & idem & idem & functionele & 33.3 & (Peiro, 1986) \\
\hline $\begin{array}{l}\text { Constable en } \\
\text { Russell * } \\
\text { (1986) }\end{array}$ & $\begin{array}{l}\text { taakverruiming } \\
\text { werkdruk } \\
\text { controle }\end{array}$ & burnout & chef & 11.1 & $\begin{array}{l}5.6 \\
\text { (Constable en }\end{array}$ \\
\hline $\begin{array}{l}\text { Constable en } \\
\text { Russell * } \\
(1986)\end{array}$ & idem & idem & collega's & 0 & Russell, 1986) \\
\hline $\begin{array}{l}\text { Roelens * } \\
\text { (1986) }\end{array}$ & $\begin{array}{l}\text { gebrek aan } \\
\text { autonomie } \\
\text { laag loon }\end{array}$ & burnout & cheff & 0 & \\
\hline $\begin{array}{l}\text { Roelens * } \\
\text { (1986) }\end{array}$ & idem & idem & collega's & 0 & (Roellens, 1986) \\
\hline $\begin{array}{l}\text { Roelens } \\
(1986)\end{array}$ & idem & idem & artsen & 0 & \\
\hline $\begin{array}{l}\text { Jayaratne en } \\
\text { Chess (1984) }\end{array}$ & $\begin{array}{l}\text { rolconflict } \\
\text { rolambiguiteit }\end{array}$ & $\begin{array}{l}\text { arbeidstewr. } \\
\text { deperson. } \\
\text { emot.uitputting }\end{array}$ & chef & 14.3 & \\
\hline & & $\begin{array}{l}\text { angst } \\
\text { depressie } \\
\text { geïriteerdheid } \\
\text { somat. klacht }\end{array}$ & & & $\begin{array}{l}10.7 \\
\text { (Jayaratne en Chess, 1984) }\end{array}$ \\
\hline $\begin{array}{l}\text { Jayaratne en } \\
\text { Chess (1984) }\end{array}$ & idem & idem & collega's & 7.1 & \\
\hline
\end{tabular}

* Studies verricht bij verpleegkundige populaties

** totale sociale steun-score inclusief steun vanuilt thuissituatic 
"Actief het probleem aanpakken": resultaten subgroep-regressie-analyses (mediaan $=2.750$ ) $a$ )

\begin{tabular}{|c|c|c|c|c|c|c|c|}
\hline predictor & criterium & $\mathrm{ni}$ & p/Fch & $\mathrm{b}$ & SEb & a & $\mathrm{T}$ \\
\hline $\begin{array}{l}\text { complexiteidy } \\
\text { moeillijkbeid }\end{array}$ & tevredenheid & $\begin{array}{l}\text { 1)285 } \\
\text { 2)180 } \\
\text { 3) } 472\end{array}$ & $\begin{array}{l}.837 \\
.006 \\
.012\end{array}$ & $\begin{array}{l}.004 \\
.089 \\
.045\end{array}$ & $\begin{array}{l}.022 \\
.032 \\
.018\end{array}$ & $\begin{array}{l}3.27 \\
2.91 \\
3.11\end{array}$ & 2.179 \\
\hline werkdruk & $\begin{array}{l}\text { eigen } \\
\text { werkwaardering }\end{array}$ & $\begin{array}{l}\text { 1)325 } \\
\text { 2) } 204 \\
\text { 3) } 537\end{array}$ & $\begin{array}{l}.405 \\
.101 \\
.648\end{array}$ & $\begin{array}{r}.019 \\
-.045 \\
.008\end{array}$ & $\begin{array}{l}.023 \\
.027 \\
.018\end{array}$ & $\begin{array}{l}3.92 \\
4.46 \\
4.09\end{array}$ & 1.829 \\
\hline $\begin{array}{l}\text { feedback/ } \\
\text { duidelijkheid }\end{array}$ & $\begin{array}{l}\text { verzuimfreq. } \\
(\log )\end{array}$ & $\begin{array}{l}\text { 1) } 234 \\
\text { 2) } 155 \\
\text { 3) } 395\end{array}$ & $\begin{array}{l}.041 \\
.607 \\
.288\end{array}$ & $\begin{array}{l}-.043 \\
.012 \\
-.016\end{array}$ & $\begin{array}{l}.021 \\
.024 \\
.015\end{array}$ & $\begin{array}{l}0.47 \\
0.28 \\
0.38\end{array}$ & 1.737 \\
\hline
\end{tabular}

a) gecorrigeerd voor de effecten wan de vier controle-variabelen "geslacht", "functie", "soort betrekking" en "jaren werkzaam in het ziekenhuis" in de eerste stap van de regressie.

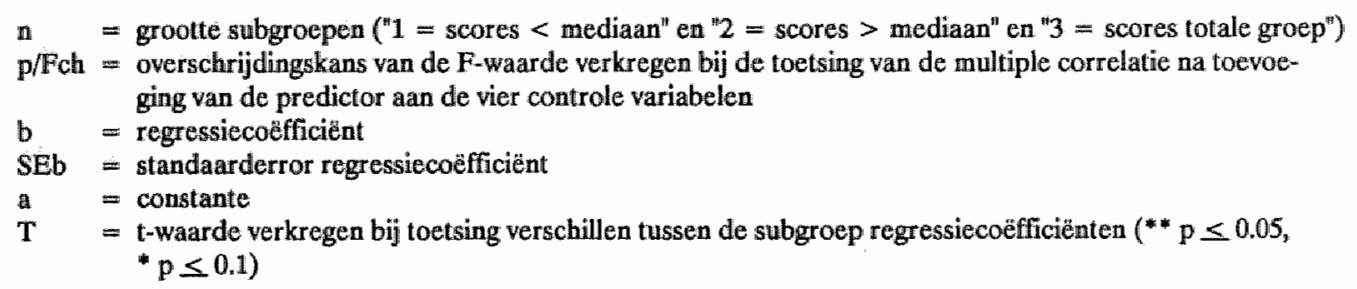




\section{BIJLAGE 12}

"Comforting cognitions": resultaten subgroep-regressie-anallyses (medỉaan $=\mathbf{2 . 2 5 0}$ ) a)

\begin{tabular}{|c|c|c|c|c|c|c|c|}
\hline predictor & criterium & n & $\mathrm{p} / \mathrm{Fch}$ & $b$ & $\mathrm{SEb}$ & $\bar{a}$ & $\mathrm{~T}$ \\
\hline $\begin{array}{l}\text { complexiteit } \\
\text { moeilijkheid }\end{array}$ & tevredenheid & $\begin{array}{l}\text { 1) } 296 \\
\text { 2) } 173 \\
\text { 3) } 472\end{array}$ & $\begin{array}{l}.000 \\
.538 \\
.012\end{array}$ & $\begin{array}{r}.083 \\
-.020 \\
.045\end{array}$ & $\begin{array}{l}.022 \\
.032 \\
.018\end{array}$ & $\begin{array}{l}2.90 \\
3,52 \\
3.11\end{array}$ & $\begin{array}{l}2.659 \\
* * * *\end{array}$ \\
\hline $\begin{array}{l}\text { verz/begel. } \\
\text { activiteiten }\end{array}$ & tevredenheid & $\begin{array}{l}\text { 1) } 299 \\
\text { 2) } 177 \\
\text { 3) } 479\end{array}$ & $\begin{array}{l}.000 \\
.215 \\
.000\end{array}$ & $\begin{array}{l}.138 \\
.045 \\
.103\end{array}$ & $\begin{array}{l}.027 \\
.036 \\
.021\end{array}$ & $\begin{array}{l}2.62 \\
3.14 \\
2.81\end{array}$ & 2,083 \\
\hline $\begin{array}{l}\text { compllexiteit" } \\
\text { moeilijkheid }\end{array}$ & $\begin{array}{l}\text { eigen } \\
\text { werkwaardering }\end{array}$ & $\begin{array}{l}\text { 1)313 } \\
\text { 2) } 187 \\
\text { 3) } 506\end{array}$ & $\begin{array}{l}.000 \\
.090 \\
.000\end{array}$ & $\begin{array}{l}.119 \\
.046 \\
.095\end{array}$ & $\begin{array}{l}.027 \\
.027 \\
.018\end{array}$ & $\begin{array}{l}3.50 \\
3.85 \\
3.60\end{array}$ & 2.113 \\
\hline $\begin{array}{l}\text { taak (versus } \\
\text { patiënt)verpl. }\end{array}$ & $\begin{array}{l}\text { eigen } \\
\text { werkwaardering }\end{array}$ & $\begin{array}{l}\text { 1) } 318 \\
\text { 2)184 } \\
\text { 3) } 509\end{array}$ & $\begin{array}{l}.002 \\
.212 \\
.056\end{array}$ & $\begin{array}{r}-.080 \\
.033 \\
-.035\end{array}$ & $\begin{array}{l}.025 \\
.027 \\
.018\end{array}$ & $\begin{array}{l}4.39 \\
3.99 \\
4.23\end{array}$ & $\begin{array}{l}3.155 \\
* * * *\end{array}$ \\
\hline $\begin{array}{l}\text { feedback/ } \\
\text { dunidelikkheid }\end{array}$ & $\begin{array}{l}\text { verzuimfreq. } \\
\text { (log) }\end{array}$ & $\begin{array}{l}\text { 1) } 235 \\
\text { 2) } 154 \\
\text { 3) } 395\end{array}$ & $\begin{array}{l}.023 \\
.191 \\
.288\end{array}$ & $\begin{array}{r}-.046 \\
.032 \\
-.016\end{array}$ & $\begin{array}{l}.020 \\
.024 \\
.015\end{array}$ & $\begin{array}{l}0.51 \\
0.13 \\
0.38\end{array}$ & 2.446 \\
\hline $\begin{array}{l}\text { soc.emotioneel } \\
\text { leiderschap }\end{array}$ & $\begin{array}{l}\text { verzuimfreq. } \\
\text { (log) }\end{array}$ & $\begin{array}{l}\text { 1) } 244 \\
\text { 2) } 160 \\
\text { 3) } 410\end{array}$ & $\begin{array}{l}.089 \\
.133 \\
.571\end{array}$ & $\begin{array}{r}.039 \\
.043 \\
-.011\end{array}$ & $\begin{array}{l}.023 \\
.028 \\
.018\end{array}$ & $\begin{array}{l}0.43 \\
0.14 \\
0.34\end{array}$ & $\begin{array}{l}2.258 \\
* *\end{array}$ \\
\hline $\begin{array}{l}\text { instrumenteel } \\
\text { leiderschap }\end{array}$ & $\begin{array}{l}\text { verzuimfreq. } \\
\text { (log) }\end{array}$ & $\begin{array}{l}\text { 1) } 240 \\
\text { 2) } 162 \\
\text { 3) } 409\end{array}$ & $\begin{array}{l}.332 \\
.078 \\
.704\end{array}$ & $\begin{array}{r}-.025 \\
.063 \\
.008\end{array}$ & $\begin{array}{l}.026 \\
.035 \\
.021\end{array}$ & $\begin{array}{l}0.36 \\
0.10 \\
0.29\end{array}$ & $\begin{array}{l}2.002 \\
* *\end{array}$ \\
\hline
\end{tabular}

a) gecorrigeerd voor de effecten van de vier controle-variabelen "geslacht", "functie", "soort betrekking" en "jaren werkzaam in het ziekenhuis" in de eerste stap van de regressie.

$\mathrm{n} \quad=$ grootte subgroepen ("1 = scores $<$ mediaan" en $2=$ scores $>$ median" en " $3=$ scores totale groep")

$\mathrm{p} / \mathrm{Fch}=$ overschrijdingskars wan de F-waarde verkregen bij de toetsing van de multiple correlatie na toevoeging van de predictor aan de vier controle variabelen

$\mathrm{b} \quad=$ regressiecoëficiënt

$\mathrm{SEb}=$ standaarderror regressiecoëfficiènt

a $=$ constante

$T \quad=t$-waarde werkregen bij toetsing verschillen tussen de subgroep regressitccoëfficienten $(* * * * p \leq 0.01$, *** $\mathrm{p} \leq 0.02, * * \mathrm{p} \leq 0.05$, $\mathrm{p} \leq 0.1)$ 


\section{DANKWOORD}

Dat de mate van "social support" een bellangrijke bijdrage kan leveren aan de werkbeleving heb ik aan den lijve ondervonden bij de uitvoering van dit onderzoek en de voorbereiding van het proefschrift. Dit boekwerk zou namelijk nooit tot stand zijn gekomen als ik niet verschillende soorten hulpbronnen zou hebben kunnen aanboren.

Allereerst een woord van dank aan de directies van de ziekenhuizen die hun goedkeuring hebben verleend aan de deelname van de verpleegafdelingen aan dit onderzoek. Leden van het verpleegkundig management en de verpleegkundigen ben ik erkentelijk voor de voortreffelijke organisatie van de afname van de enquêtes en de bereidheid de "omvangrijke" vragenlijst in werktijd in te vullen.

De leden van de beoordelingscommissie ben ik dank verschuldigd voor de bruikbare aanwijzingen die de kwaliteit van dit proefschrift ten goede zijn gekomen.

Een aantal personen wier betrokkenheid bij mij en het onderzoek onontbeerlijk zijn geweest de afgelopen jaren wil ik met name noemen.

De samenwerking met mijn co-promotor Dr. J.A. Landeweerd heb ik als bijzonder plezierig en leerzaam ervaren. De deur van zijn kamer stond altijd voor mij open. Zijn nuchtere aanpak heeft steeds een geruststellende werking op mij uitgeoefend. $\mathrm{Ab}$, bedankt voor het vertrouwen dat je in mij gesteld hebt.

Mijn promotor, Prof.Dr. J.J.C.B. Bremer ben ik erkentelijk voor de kritische en vlotte correcties van de aangeleverde teksten. Joost, mijn dank voor de nauwgezetheid waarmee je de begeleiding van het schrijven van het manuscript op je hebt genomen.

Het waardevolle commentaar van Dr. F. Nijhuis op eerdere versies van het proefschrift heb ik zeer op prijs gesteld. Frans, de gesprekken met jou over de verschillende facetten van mijn onderzoek zijn voor mij steeds verhelderend en inspirerend geweest.

Van de deskundigheid van Drs. J.H.M. van Houtem op het gebied van de dataverwerking heb ik talloze malen dankbaar gebruik gemaakt. Jan, jij stond altijd voor mij klaar, beantwoordde geduldig mijn vragen en verdiepte je in een onderzoeksveld dat niet het jouwe is. Mijn dank voor je inzet en onvermoeibaar geduld.

Mevrouw I. van Noppen heeft op een snelle en accurate wijze de uiteindelijke lay-out van dit proefschrift verzorgd. Isel, jouw bijdrage heb ik bijzonder gewaardeerd. In de drukke periode die vooraf gaat aan een promotie was jij bereid mij een belangrijk stuk werk uit handen te nemen.

Afsluiten wil ik dit dankwoord met een vermelding van de "supporters" aan het thuisfront. Allereerst wil ik mijn ouders dankzeggen, die mij in mijn studie en werk altijd gestimuleerd hebben. Last but not least richt ik mij tot jou, Paul. Jouw loyaliteit en niet aflatend optimisme zijn voor mij onmisbaar geweest in deze voor mij zo belangrijke periode wan mijn leven. 


\section{CURRICULUM VTTAE}

Nicolle P.G. Boumans werd geboren op 16 maart 1963 te Heerlen. Ze volgde een Middelbare Schoolopleiding aan het Coriovallum College te Heerlen, waar zij in 1981 het eindexamen gymnasium alpha behaalde. In datzelfde jaar begon ze aan de Rijksuniversiteit Limburg met de studie Gezondheidswetenschappen. In 1985 behaalde ze het doctoraal examen, met als afstudeerrichting Verplegingswetenschap. In september 1985 trad zij als tijdelijk medewerkster in dienst bij de vakgroep Medische Psychologie van de Universiteit Limburg. 